Neuroecologia na ordem Rodentia: aspectos da cognição espacial em ratos-de-espinho e a evolução da encefalização

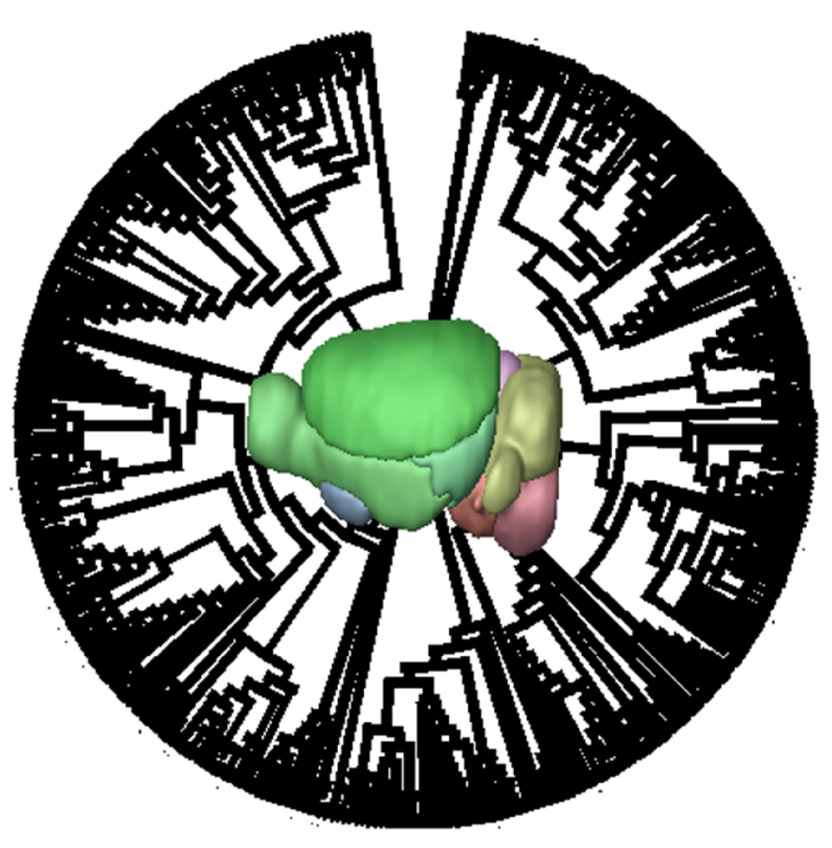

Jorge Nei Silva de Freitas 
JORGE NEI SILVA DE FREITAS

\section{Neuroecologia na ordem Rodentia: aspectos da cognição espacial em ratos-de-espinho e a evolução da encefalização}

(Versão original)

Tese apresentada ao Instituto de Psicologia da Universidade de São Paulo (USP) para obtenção do título de Doutor em Neurociências e Comportamento.

Área de concentração: Neurociências e comportamento

Orientadora: Prof. Dr ${ }^{\mathrm{a}}$. Elisabeth Spinelli de Oliveira 
AUTORIZO A REPRODUÇÃO E DIVULGAÇÃO TOTAL OU PARCIAL DESTE TRABALHO, POR QUALQUER MEIO CONVENCIONAL OU ELETRÔNICO, PARA FINS DE ESTUDO E PESQUISA, DESDE QUE CITADA A FONTE.

Catalogação na publicação

Freitas, Jorge Nei Silva de.

Neuroecologia na ordem Rodentia: aspectos da cognição espacial em ratos-de-espinho e a evolução da encefalização / Jorge Nei Silva de Freitas; orientadora Elisabeth Spinelli de Oliveira. -- São Paulo, 2013.

$154 \mathrm{f}$.

Tese (Doutorado - Programa de Pós-Graduação em Psicologia. Área de Concentração: Neurociências e Comportamento) - Instituto de Psicologia da Universidade de São Paulo.

1. Rodentia 2. Neuroecologia 3. Cognição espacial 4. Evolução 5. Encefalização I. Título. 


\section{Folha de aprovação}

Jorge Nei Silva de Freitas

Neuroecologia na ordem Rodentia: aspectos da cognição espacial em ratosde-espinho e a evolução da encefalização

Tese apresentada ao Instituto de Psicologia da USP para obtenção do título de Mestre em Neurociências e comportamento.

Aprovada em:

Banca Examinadora

(Nome e assinatura)

(Nome e assinatura)

(Nome e assinatura)

(Nome e assinatura) 
"Não herdamos a sabedoria, precisamos descobri-la por nós mesmos, através de experiências que ninguém pode ter por nós e das quais ninguém nos pode poupar”.

Marcel Proust

"Nada na Biologia faz sentido exceto à luz da evolução." Theodosius Dobzhansk 


\section{Agradecimentos:}

Ao meu tio Cacildo (in memorian) pelo carinho, dedicação e força durante o apoio no antes e no início de tudo desta jornada, mas que mesmo não estando aqui deixou boas

memórias.

Aos meus pais por serem minha origem e o meu porto seguro, pelo amor, educação e dedicação ao meu crescimento como ser humano.

À Adriana e a pequena Ana Clara que brotou trazendo alegria e renovação de vida.

À Profa. Dra. Elisabeth Spinelli de Oliveira que me acolheu como orientando e compartilhou sua experiência e sabedoria.

Aos membros da banca examinadora por contribuírem na melhoria deste trabalho.

Ao Msc Leandro Magrini pela colaboração, discussões metodológicas e conceituais.

À Profa Dra Patrícia Monticelli pelo apoio e parceria nos trabalhos de campo.

À Profa Dra. Tiana Kolsdorf e ao prof. Dr Pedro Rocha pelos conselhos científicos.

Ao Prof Dr José Lino de Oliveira Bueno pelas recomendações e o contato acadêmico.

À Profa Dra. Leila Maria Pessôa e ao Prof Dr João Oliveira pelo entusiasmo, acolhida e apoio cientifico ao projeto.

À Msc Priscila Camelier pela amizade, apoio e singular hospitalidade.

Às técnicas Thalita Riul e Ana Paula dos Santos pelo apoio.

Ao colaborador de coleta Manoel Atemy dos Santos pela grande ajuda no campo.

Aos amigos e colegas Newton Monte-Alegre, Leonardo Fernandes, Bruno Durães, Wilfried Klein, Leandro Magrini, Patrícia Monticelli, Bruno Favaretto, Larissa Dias, Laís Ruiz, Ana Paula Fabio, Mítia Ganade, Guilherme Cervelle, Tábata Cordeiro, Daniela Ventura, 
Adriana Sicuto, Sergio Urquízu, Danilo Benette, Rafaella Volpi, Melina Vaz, Lilian Luchesi, Priscila Camelier, Wagner dos Santos, Leonardo Sampaio, Alex Rolim, André Mota, Juliana Malange, Caprice Lima e ao pessoal do EBAC por serem pessoas que fizeram parte desta jornada e estão no meu tempo, coração e na minha memória.

À CAPES pela concessão da bolsa que além da minha manutenção possibilitou financiar parte das minhas viagens e coletas.

À FAPESP pelo auxílio financeiro indireto deste projeto.

Ao IBAMA por ter cedido à licença de coleta dos animais.

À COTEC e Estação experimental de Itirapina pelo apoio ao trabalho de campo.

Ao Museu Nacional (UFRJ) e Museu de Zoologia da USP pelo apoio na coleta de dados.

Aos roedores que conquistaram, evoluíram e mudaram o mundo e nossas vidas.

Muito obrigado !!! 


\section{SUMÁRIO:}

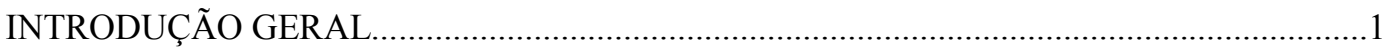

CAP'ÍTULO 1 COGNIÇÃO ESPACIAL E SUA RELAÇÃO COM HÁBITO FOSSORIAL EM TRÊS ESPÉCIES DE RATOS-DE-ESPINHOS (ECHIMYIDAE: RODENTIA): IMPLICAÇÕES EVOLUTIVAS

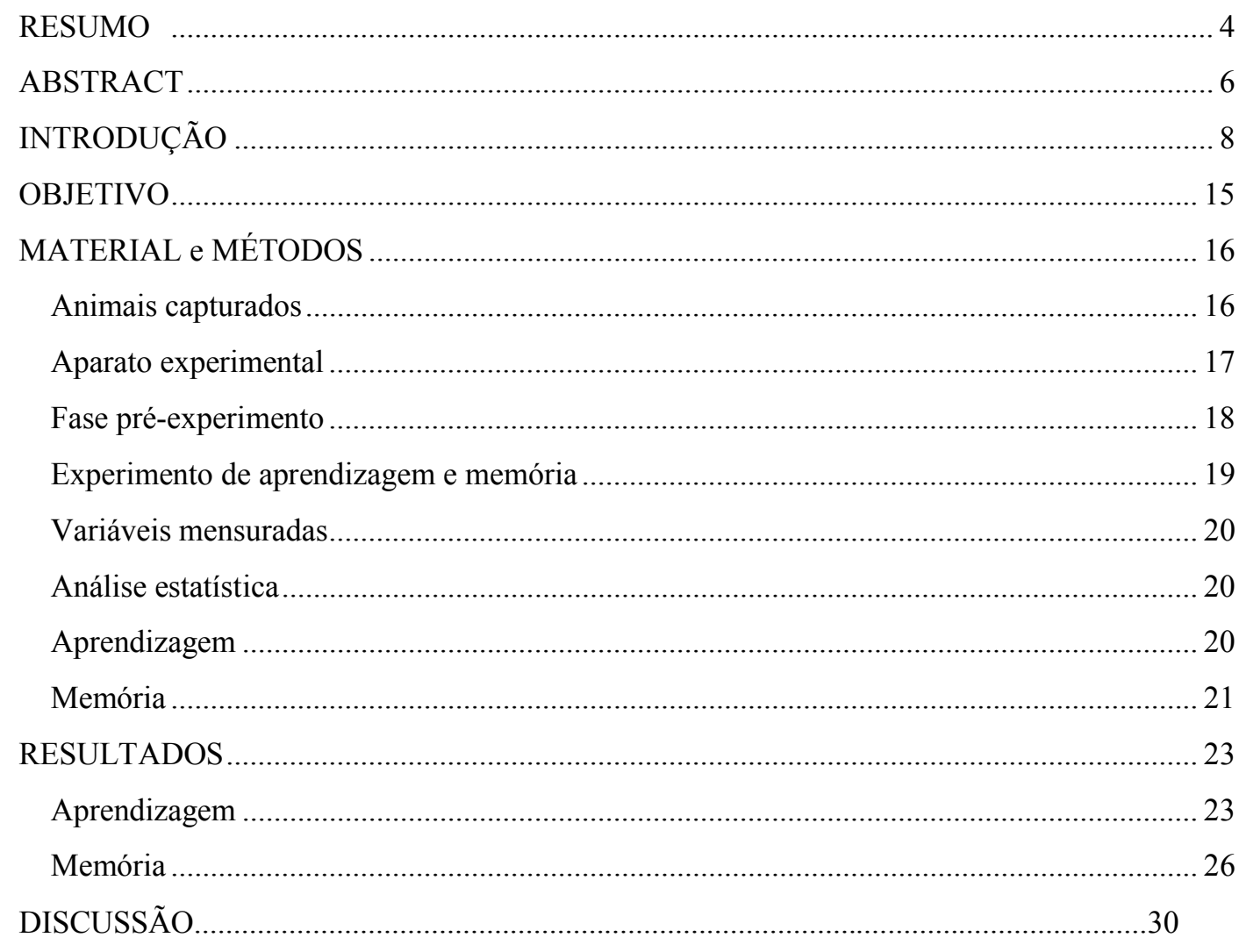

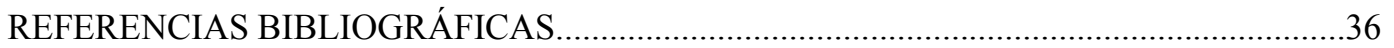

CAP'ÍTULO 2 EVOLUÇÃO DA ENCEFALIZAÇÃO NA ORDEM RODENTIA E SUAS DETERMINANTES ECOLÓGICAS, ETOLÓGICAS E DO DESENVOLVIMENTO

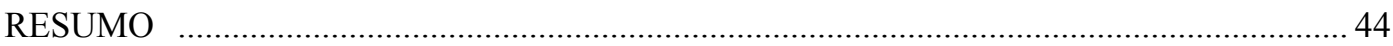

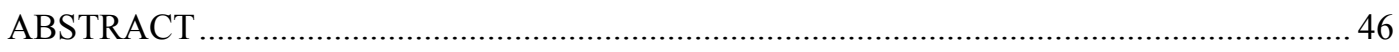

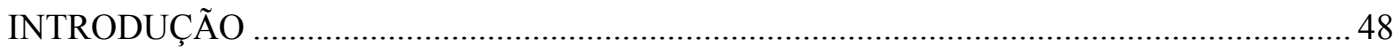

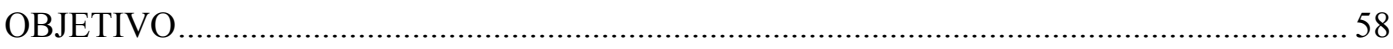

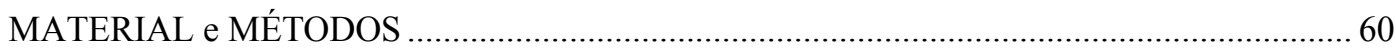

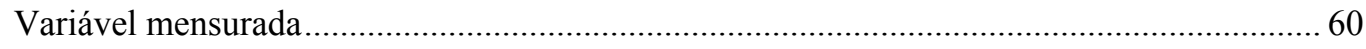

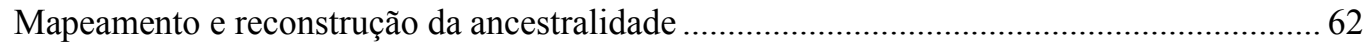

Classificação das espécies quanto aos fatores ecológicos ecologicos, sociais e do

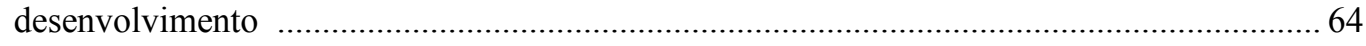

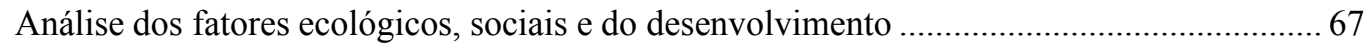

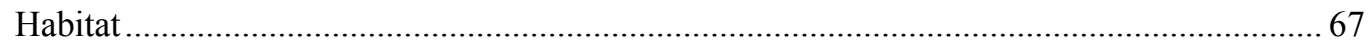




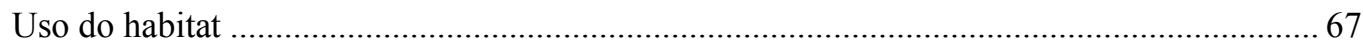

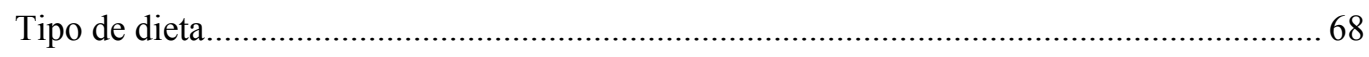

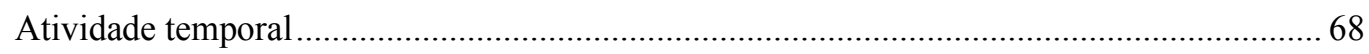

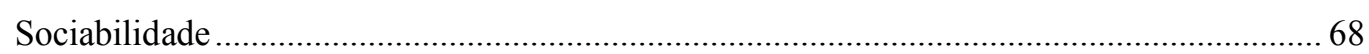

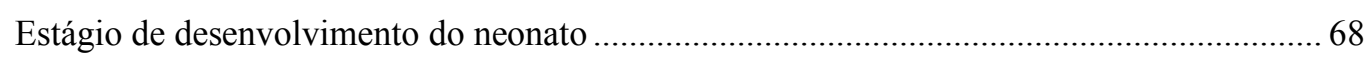

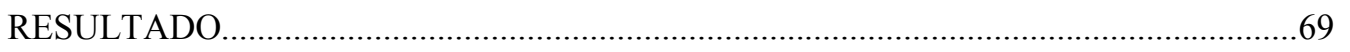

Mapeamento e reconstrução da ancestralidade .......................................................... 70

Análise dos fatores ecologicos, sociais e do desenvolvimento.......................................79

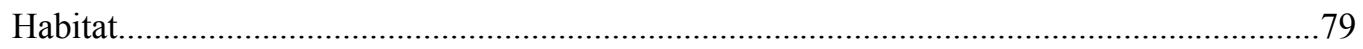

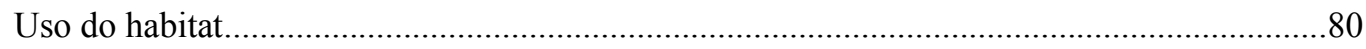

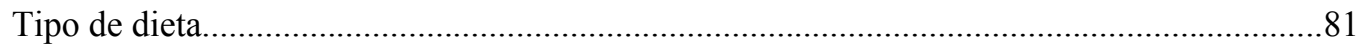

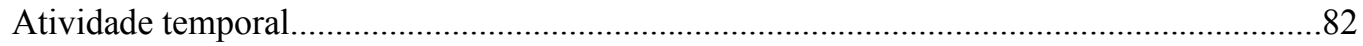

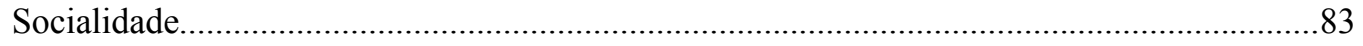

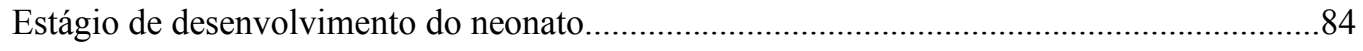

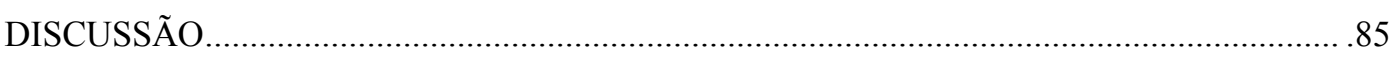

Mapeamento e reconstrução da ancestralidade ............................................................ 85

Análise dos fatores ecologicos, sociais e do desenvolvimento............................................96

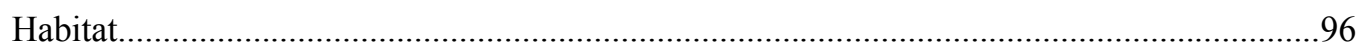

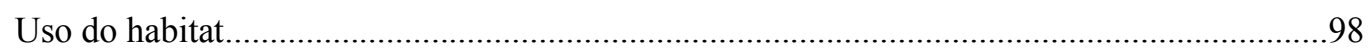

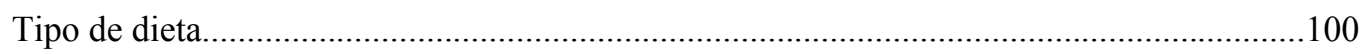

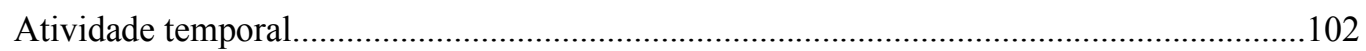

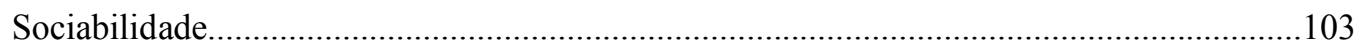

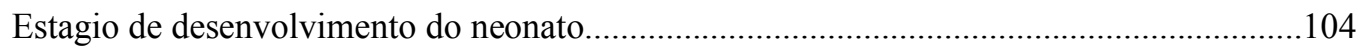

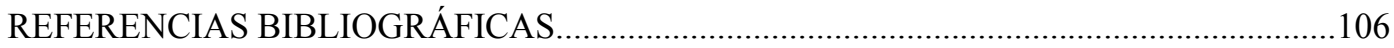

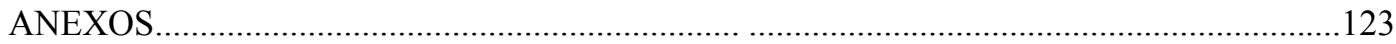




\section{INTRODUÇÃO GERAL}

A relação da etologia, cognição e ecologia com a variação do tamanho do encéfalo como um todo ou de suas partes tem levantado questões na biologia evolutiva (LEFEBVRE et al, 2004). A atuação diferenciada de pressões seletivas sobre diferentes partes do encéfalo pode ocasionar o aumento desproporcional e independente de seus tamanhos, dando suporte à hipótese da evolução em mosaico que demonstrou que o encéfalo não evoluiu como uma estrutura unitária (Rilling \& InSEl, 1998; Barton \& HARVey, 2000; Marino ET AL, 2000; KAAS \& Collins, 2001; Whiting \& BARTOn, 2003; IWANIUK ET AL, 2004; SCHOENEMANN ET AL, 2005; STRIEDTER, 2005).

Em decorrência deste novo achado e com base em estudos anteriores (EISENBERG \&Wilson, 1978; BARTON ET AL, 1995; BARTON, 1996; 1998; SZEKELY ET AL, 1996; FRAHM ET AL, 1997; SAFI \& DECHMANN, 2005), o papel da ecologia ganhou relevância na análise dos processos evolutivos que atuam sobre diferentes estruturas encefálicas. A partir daí novos programas de pesquisa surgiram, dentre eles, a Neuroecologia que tem se destacado devido a uma abordagem que envolve o estudo comparado da variação adaptativa no encéfalo e no comportamento (BOLHUIS \& MACPHAIL 2001; BOLHUIS, 2005; SHERRY, 2006). Ela é baseada na premissa de que demandas ecológicas em particular sobre funções cognitivas, motoras e de percepção influenciam o tamanho de estruturas do encéfalo que suportam estas funções (LefeVbre et 2004; Sherry, 2006; RAtClifFe, 2009; SMulders ET AL, 2010). No entanto, os traços comportamentais também podem ser resultado do aumento coordenado do encéfalo como um todo (FINLAY \& DARLington 1995). Aliado a isso há uma tendência geral nos mamíferos para aumento da complexidade comportamental associada à encefalização (CHANGIZI 2003). 
Assim a neurocologia também pode estudar a variação do tamanho do encéfalo e testar a sua associação com da etologia com a ecologia.

Os roedores estão dentre os modelos estudados na neuroecologia, porém estes estudos têm sido aplicados em sua maioria a grupos neárticos (BUDEAU \& VERTS 1986; JACOBS ET AL, 1990; JACOBS \& SPENCER, 1994; LAVENEX ET AL 2000), apesar da diversidade neotropical para roedores exibir diversos casos irradiação adaptativa como, por exemplo, os Hystricognathi e os Sigmodontinae que ocuparam a América do Sul em momentos distintos resultando na ocupação de diversos nichos ecológicos e estilos de vida (HONEYCUTT ET AL 2007), proporcionando um bom modelo de estudo evolutivo. Além disso, a ordem Rodentia na sua totalidade é a mais diversificada em termos específicos com mais de 2200 espécies (43\% da diversidade de mamíferos) (WILSON \& REEDER 2005), ecológicos (habitats, estilos de vida), de tamanho corporal e biogeográficos (EISENBERG 1981; NOWAK 1999; FABRE ET AL 2012), aliado a isso eles são acessíveis e de facil manipulação , o que se torna um táxon interessante para o estudo comparativo filogenético de grande escala sobre os aspectos funcionais e evolutivos sistema nervoso.

Após a determinação de um modelo de estudo, os estudos em neuroecologia dependem inicialmente da avaliação da relação da ecologia (habitat e o uso do habitat) com o comportamento (sociabilidade) e a cognição (aprendizagem ou memória espacial) e num segundo momento da avaliação da relação destas características com o encéfalo ou parte do encéfalo de interesse.

Neste trabalho avaliamos a neuroecologia em Rodentia a partir de duas abordagens apresentadas em dois capítulos (1) a avaliação da relação da cognição espacial de roedores com a sua ecologia relacionada aos hábitos fossorial, semi-fossorial e terrestre da família echimyidae 
(Hystricompha) e por fim (2) avaliaremos a evolução da encefalização em Rodentia com espécies de todos os grandes clados do grupo através da reconstrução e mapeamento da ancestralidade da encefalização na filogenia e em seguida testaremos hipóteses que explicam a causa da encefalização com relação à ecologia, sociabilidade e desenvolvimento. 


\section{COGNIÇÃO ESPACIAL E SUA RELAÇÃO COM HÁBITO FOSSORIAL EM TRÊS ESPÉCIES DE RATOS-DE-ESPINHOS (ECHIMYIDAE: RODENTIA): IMPLICAÇÕES EVOLUTIVAS}

(CAPÍTULO 1) 


\section{RESUMO}

FREITAS, J. N. S. COGNIÇÃO ESPACIAL E SUA RELAÇÃO COM HÁBITO FOSSORIAL EM TRÊS ESPÉCIES DE RATOS-DE-ESPINHOS (ECHIMYIDAE: RODENTIA): IMPLICAÇÕES EVOLUTIVAS. 2013. Tese (Doutorado). Instituto de Psicologia Neurociências e Comportamento - Universidade de São Paulo, São Paulo, 2013.

As diferentes demandas ecológicas impostas pela vida epígea e hipógea podem favorecer a melhoria das funções cognitivas espaciais. Comparamos a aprendizagem e a memória espacial, em labirinto complexo do Trinomys iheringi denigratus (terrestre de Mata Atlântica), T.yonenagae (semi-fossorial das Dunas na Caatinga) e Clyomys bishopi (fossorial do Cerrado). O aprendizado e memória espacial foram avaliados 10 T.i.denigratus $(250 \pm 34 \mathrm{~g}), 18$ T.yonenagae (125 $\pm 7,8 \mathrm{~g})$ e seis Clyomys bishopi $(338 \pm 34 \mathrm{~g}$ ), a partir do: tempo até a saída do labirinto (TFL) e o número de erros cometidos (NER), em indivíduos colocados em labirinto de seis caminhos cegos e uma saída $(0,20 \times 1,10 \times 1,50 \mathrm{~m})$, durante cinco testes consecutivos (30min) por dia, durante três dias consecutivos (fase de aprendizagem). Os ratos foram novamente testados em única sessão realizada após 48,120 e 504h (fase de memória). O desempenho foi testado ao longo dos testes utilizando uma ANOVA um-fator $(p<0,05)$. As taxas de aprendizagem (TA) do TFL das duas espécies foram mensuradas a partir do $b$ da equação da curva de aprendizagem, e comparadas usando-se ANOVA um-fator $(\mathrm{p}<0,05)$. As variáveis do último teste de cada dia com os do primeiro teste do dia seguinte foram usadas como indicativas de memória-de-médio-prazo (MMP) e comparadas por espécie (teste $\mathrm{T}$, dados-pareados, $\mathrm{p}<0,05$ ). As taxas de retenção da aprendizagem (TR) com relação aos intervalos dos testes de memória, foram usadas como índice de memória-de-longo-prazo (MLP) e foram comparadas pela ANOVA um-fator $(p<0,05)$. As espécies não apresentaram diferença significativa entre si mas não entre os testes tanto para TFL $(\mathrm{F}=0,85 ; \mathrm{p}=0,705 ; \mathrm{F}=8,86 ; \mathrm{P}<0,000)$ quanto para NER $(\mathrm{F}=0,56 ; \mathrm{p}=0,979 ; \mathrm{F}=3,65 ; \mathrm{p}=0,000)$. A TA foi marginalmente significativa $(\mathrm{F}=2,784 ; \mathrm{p}=0,077)$ entre as espécies, sendo que $T$. yonenagae e C. bishopi não apresentaram diferença entre eles e ambos diferiram do $T$. $i$. denigratus. Com relação à memória-de-médio-prazo, T. Yonenagae e T. i. denigratus apresentaram diferença significativa para TFL entre os testes 10-11 $(\mathrm{t}=-3,406 ; \mathrm{p}=0,003)(\mathrm{t}=-$ 2,300; $\mathrm{p}=0,050)$, mas não entre os testes $5-6(\mathrm{t}=-0,779 ; \mathrm{p}=0,447)(\mathrm{t}=-1,061 ; \mathrm{p}=0,320)$. Já $\mathrm{o}$ C.bishopi sofreu redução entre os testes 5-6 e os testes 10-11, mas sem diferença significativa. Para a variável NER, não foi detectada diferença significativa, tanto para T. yonenagae (entre os 
testes 5 e 6: $\mathrm{t}=314,000, \mathrm{P}=0,558$; testes 10 e 11: $\mathrm{t}=325,000, \mathrm{P}=0,812)$ quanto para T.i.denigratus (entre os testes 5-6, $\mathrm{t}=0,590, \mathrm{P}=0,562$; testes $10-11$ : $\mathrm{t}=-1,855 \mathrm{P}=0,080$ ), por outro lado, C. bishopi apresentou a tendência de redução dos valores de NER entre os testes 5-6 $(\mathrm{t}=$ $0,442 ; \mathrm{p}=0,676)$ e $10-11(\mathrm{t}=3,558 ; \mathrm{p}=0,016)$ sendo esta significativa. Quanto à MLP, dentre cada espécie não houve diferença significativa. Assim o semi-fossorial T.yonenagae e o fossorial C.bishopi se destacam quanto a aprendizagem do que a terrestre T.idenigratus, entretanto apenas C.bishopi é mais eficiente com relação a memoria-de-médio-prazo. Caso o efeito da filogenia seja controlada, sugere-se que o hábito fossorial seja componente do regime seletivo para evolução da cognição espacial. Palavras-chave: Aprendizagem e memória espacial, fossorialidade, Trinomys, Clyomys, labirinto complexo, semi-fossorial, evolução 


\section{ABSTRACT}

FREITAS, J. N. S. SPATIAL COGNITION AND ITS RELATION WITH FOSSORIALITY IN THREE SPECIES OF SPINY-RATS (ECHIMYIDAE: RODENTIA): EVOLUTIONARY IMPLICATIONS. In 2013. Thesis (Ph.D.). Instituto de Psicologia - NeC - Universidade de São Paulo, São Paulo, 2013.

The different ecological contests imposed by epigeal and hypogeal lifestyles can facilitate the improvement of cognition spatial. We compared the spatial learning and memory in complex maze of Trinomys iheringi denigratus (terrestrial Atlantic rainforest), T.yonenagae (semifossorial Dunes of Caatinga) and Clyomys bishopi (fossorial of Cerrado). The spatial learning and memory were assessed 10 T.i.denigratus $(250 \pm 34 \mathrm{~g}), 18$ T.yonenagae $(125 \pm 7.8 \mathrm{~g})$ and six Clyomys bishopi $(338 \pm 34 \mathrm{~g})$, from: time to exit the maze (TFL) and the number of errors (NER) in individuals placed on the complex maze of paths six blind and an outlet $(0,20 \times 1,10 \times 1,50 \mathrm{~m})$ for five consecutive tests (30min) per day for three consecutive days (learning phase). The rats were tested in one session held after 48, 120 and 504Hours (memory phase). The performance was analyzed over the tests using a one-way ANOVA $(p<0.05)$. Learning rates (TA) of the TFL of both species were measured from the $b$ of the equation of the learning curve, and compared using one-way ANOVA $(\mathrm{p}<.05)$. The variables for each of the last test day with the first test the following day were used as indicators of memory to medium-term (MMP) and compared by species (t-test, paired-data, $\mathrm{p}<0.05)$. Retention rates of learning (TR) with respect to the intervals of memory tests, were used as an index of memory-to-long-term (MLP) and were compared by one-way ANOVA $(\mathrm{p}<0.05)$. The species did not differ significantly from each other but not between tests for both TFL $(\mathrm{F}=0.85, \mathrm{p}=0.705 \mathrm{~F}=8.86, \mathrm{P}<0.000)$ and for NER $(\mathrm{F}=0.56, \mathrm{p}=0.979, \mathrm{~F}=3.65, \mathrm{p}=0.000)$. The TA was marginally significant $(\mathrm{F}=2.784, \mathrm{p}=$ 0.077 ) between species, and T. yonenagae and C. bishopi showed no difference between them and both were different from $T$. $i$. denigratus. With respect to memory-to-medium term, $T$. yonenagae and T. $i$. denigratus showed significant difference between the tests 11 and 10 for TFL $(\mathrm{t}=-3.406, \mathrm{p}=0.003)(\mathrm{t}=-2.300, \mathrm{p}=0.050)$, but not between tests 5 and $6(\mathrm{t}=-0.779, \mathrm{p}=$ $0.447)(\mathrm{t}=-1.061, \mathrm{p}=0.320)$. Already C.bishopi showed decreased between tests 5-6 and tests 10-11, but without significant difference. For variable NER, no significant differences were detected for both $T$. yonenagae (between tests 5 and $6: \mathrm{t}=314.000, \mathrm{P}=0.558$, Tests 10 and 11: $\mathrm{t}$ $=325,000 \mathrm{P}=0.812$ ) and for T.i.denigratus (between tests 5.6, $\mathrm{t}=0.590, \mathrm{P}=0.562$; Tests 10-11: 
$\mathrm{t}=-1.855 \mathrm{p}=0.080$ ), on the other hand C. bishopi showed a trend to decreased NER between tests 5-6 $(\mathrm{t}=0.442, \mathrm{p}=0.676)$ and $10-11(\mathrm{t}=3.558, \mathrm{p}=0.016)$ which is significant. As for MLP, among each species there was no significant difference. Thus the semi-fossorial T.yonenagae and fossorial C.bishopi stand out as the learning of the terrestrial T.i.denigratus, however only C.bishopi is more efficient with respect to memory-to-medium term, if the effect of phylogeny is controlled, we suggested that the fossoriality could comprising the part of selective regime for evolution of the spatial cognition. Keywords: Learning and spatial memory, fossoriality, Trinomys, Clyomys bishopi, complex maze, semi-fossorial, evolution 


\section{INTRODUÇÃO}

A aprendizagem e a memória especial são dois aspectos da cognição animal, que podem ser definidas como as capacidades de reconhecimento, codificação, armazenamento e recuperação da informação sobre o arranjo de itens ou rotas específicas no espaço (CARRILLOMora, Giordano, \& SANTAMARIA, 2009; SHETtLEworth, 2010). Os animais cuja habilidade espacial é bem desenvolvida são capazes de explorar melhor o ambiente em que vivem, acessando mais os recursos domiciliares, alimentares e reprodutivos, e consequentemente, aumentando suas chances de sobrevivência naquele habitat (BUDEAU \& VerTis 1986; Grove 2012).

Em termos evolutivos, a aprendizagem e a memória espacial são adaptações, a partir de quando estas características são funcionais (favorecem a sobrevivência e sucesso reprodutivo), surgem num regime seletivo atual e derivado (diferente do ancestral) e são fixadas na população por seleção natural (CODDINGTON 1988) conferindo ao organismo um alto valor adaptativo quando comparado ao estado plesiomórfico, sob um regime seletivo derivado (BAUM \& LARSON 1991).

Neste contexto é esperado que aquelas espécies que vivem em ambientes de grande complexidade ambiental e mais derivados, tais como o ambiente subterrâneo das tocas e túneis, sejam dependentes de uma acurada orientação espacial (ABLE 1980; GaUlin \& FitzGERALD, 1989; Pravosudov \& Clayton, 2002) e apresentem adaptações cognitivas espaciais, em relação às espécies que vivem em ambientes menos complexos e mais próximos aos ambientes ancestrais.

O ambiente hipógeo possui demandas diferenciadas frente àquela encontrada nos habitats epígeos, podemos destacar a grande redução da quantidade de pistas espaciais (ex: visuais), 
demandas por mapeamento dos túneis e a orientação precisa para redução de gasto energético na construção de túneis (KIMCHI \& TERKEL 2001; 2004). Assim estes fatores podem atuar como forças seletivas para a evolução do aumento e melhora do aprendizado e memória espacial.

Os estudos comparativos são ferramentas, que quando associada à história evolutiva das espécies, permitem compreender a natureza adaptativa da aprendizagem e memória espacial (SHERRY 2006), mas para isso, os dados devem ser coletados de maneira sistemática, de modo a testar às hipóteses geradas a partir das observações pontuais, e visando dar rigor formal da análise da significância adaptativa da estrutura do organismo, deveram ser feitos dentro de um arcabouço filogenético para o estudo do táxon (LARSON \& LOSOS 1996), ligado a isso a série de transformação dos caracteres estudados (CLUTTON-BROCK \& HARVEY 1984; HARVEY \& PAGEL 1991); (2) que detectem as principais mudanças de regime seletivo e (3) sejam capazes de integrar estes a filogenia do táxon (LARSON \& LOSOS 1996).

A escassez de estudos comparativos com roedores terrestres de superfície e fossórios, que avaliem o aprendizado e a memória espacial, seguindo estas diretrizes é notória, mas os poucos trabalhos que se aproximem deste modelo, como o de Kimchi \& Terkel (2001) demonstraram que o bom desempenho espacial do rato-toupeira Spalax pode está associado ao seu hábito fossorial e como hipótese originada deste trabalho, podemos inferir que o regime seletivo do ambiente fossorial pode favorecer a evolução de adaptações de aprendizagem e memória espacial, por outro lado, este mesmo trabalho não permite avaliar o significado adaptativo da cognição espacial, pois sua análise não leva em consideração espécies aparentadas de regime seletivos distintos e a sua filogenia. Portanto, a realização de um estudo com espécies que apresentem proximidade filogenética e semelhança ou diferença ecológica apresenta-se como bom modelo de estudo para abordagens comparativas dentro de uma perspectiva evolutiva. 
A fossorialidade evoluiu por convergência em diversas ordens de mamíferos. Na ordem Rodentia, ela surgiu no mínimo em 250 espécies de seis famílias, que vivem uma parte significativa do tempo em tocas por eles mesmas construídas (BEGALL et al, 2007) em termos morfológicos apresentam características relacionada á escavação (patas curtas e robustas com garras desenvolvidas, corpo cilíndrico, olhos pequenos). Entre o hábito terrestre e fossorial, existem aquelas espécies que mantém características morfológicas relacionadas à vida epígea, mas que dependem da vida hipógea, escavando seus próprios túneis subterrâneos sem apresentar especializações voltada ao hábito fossorial, estas espécies podem ser classificadas como semifossoriais e estão presentes em diversas famílias como: Sciuridae (gêneros Spermophilus, Marmota), Dipodidae (gêneros Allactaga), Heteromyidae (Dipodomys) e Pedetidae (Pedetes) (NOWAK 1999).

Dentre estas famílias pouco é conhecido sobre as espécies neotropicais da família Echimyidae que juntamente com Ctenomyidae, apresentam o hábito semi-fossorial e fossorial e são representantes dos Histricognatos atuais, que foram os primeiros roedores que colonizaram a América do Sul entre 40 e 60 milhões de anos atrás (HouchON \& DOUZERY, 2001: Rowe, 2002). Provavelmente o padrão ancestral deste grande grupo foi de um rato-de-espinho terrestre e silvícola (GALEWSKI et al, 2005) que sofreu irradiação adaptativa, cuja diversificação deu origem às espécies arborícolas, cursoriais, semi-fossoriais e fossoriais (Fig. 1). Sendo assim, o padrão fossorial seria derivado em relação ao padrão terrestre do grupo.

Os equimídeos com mais características associadas à vida fossorial estão em um clado de três espécies: Carterodon sulcidens, Euryzygomatomys spinosus e Clyomys bishopi (NowAK, 1999; CARVAlHo \& SAlles 2004). Em termos filogenéticos, segundo dados morfológicos e moleculares (XIMENES, dados não-publicados; UPHAM \& PATTERSON 2012), formam um grupo 
monofilético e, por conseguinte, todos eles apresentam como padrão morfológico, um corpo coberto por pelagem espinhosa, cauda de tamanho reduzido, membros curtos e garras dianteiras robustas (BISHOP 1974 APUD BEZERRA \& OliveIRA 2010). Além disso, em termos ecológicos todos habitam formações abertas como o cerrado (EISENBERG \& REDFORD, 1999).

O gênero Clyomys é o mais estudado dentre os gêneros de equimídeos fossórios, sua fisiologia respiratória e metabolismo são compatíveis com a de animais de vida subterrânea (BARROS et al, 2004), morfologicamente, é bastante singular em relação aos gêneros Carterodon e Euryzygomatomys, pois apresenta uma bula timpânica aumentada (THOMAS 1916 APUD BEZERRA \& OLIVEIRA, 2010) e quanto à etologia, ainda existem indícios pontuais de sociabilidade (NOWAK, 1999).

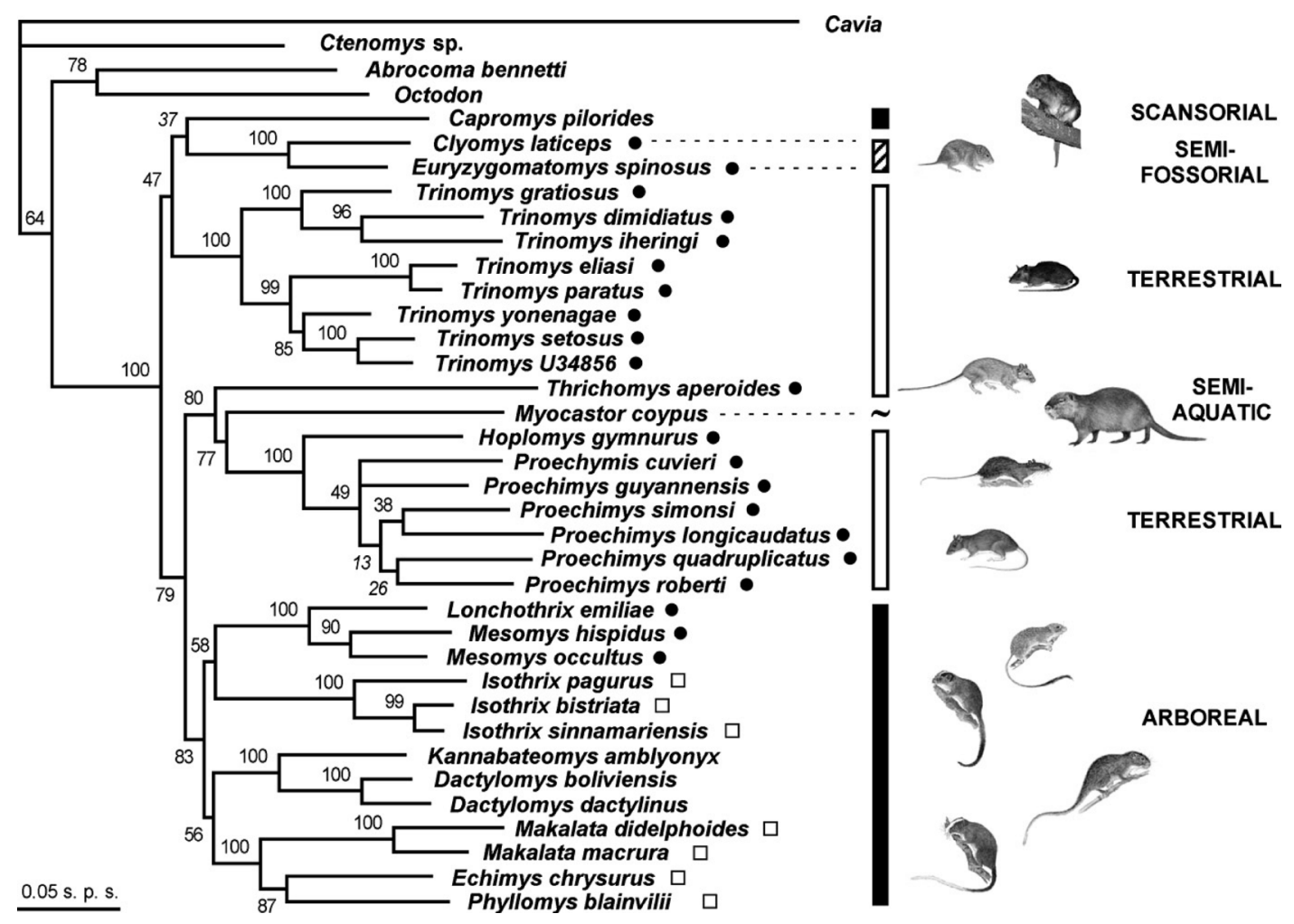

Figura 1. Representação da diversidade ecomorfológica dentro dos Echimyidae através da filogenia proposta por Galewsky (2005), baseado em dados moleculares. As espécies escansoriais e arborícolas, terrestres e semi-fossórios estão representadas respectivamente, pelos retângulos pretos, tracejados e brancos; mais à direta, está o Myocastor que é semi-aquático. As figuras correspondem as seguintes espécies, de cima para baixo, Capromys pilorides, Euryzygomatomys spinosus, Trinomys setosus, Thrichomys aperoides, Myocastor coypus, Hoplomys gymnurus, Proechimys guyannensis, Lonchothrix emiliae, Isothrix bistriata, Kannabateomys amblyonyx, e Echimys chrysurus. 
Os ratos-de-espinho do gênero Trinomys mantiveram o padrão ecológico do ancestral: terrestre e silvícola, habitando desde florestas úmidas típicas do bioma de Mata Atlântica até regiões de enclaves mésicos na transição do Cerrado-Mata Atlântica (EMmONS \& FEER, 1997; EISENBERG \& REDFORD, 1999). Além disso, o gênero Trinomys é um dos mais estudados dentre os equimídeos, pois tem se destacado por serem modelos de estudo sobre a evolução de processos fisiológicos (BARRos et al, 1998), comportamentais (MANAF \& OliveIRA, 2000; FrEITAS et al, 2008; 2010) e neuroanatômicos (RIBEIRO, 2004). Isto é favorecido pela conhecida filogenia do gênero, tanto para dados moleculares e morfológicos (LARA \& PATTON, 2000; CARVAlHO \& SAlLES, 2004), assim como a grande diversidade de suas espécies (GALEWSKI ET AL, 2006). Em termos ecológicos e etológicos, estudos sugerem que indivíduos deste gênero são geralmente solitários e territoriais (EMMONS \& FEER, 1997; NOWAK, 1999), e que as áreas domiciliares das fêmeas não se sobrepõem (FLEMING, 1971; EMMONS, 1982; STREILEIN, 1982; Bergallo, 1994, 1995; Aguilera, 1999).

A espécie Trinomys iheringi denigratus é habitante terrestre de superfície nos remanescentes de Mata Atlântica no Baixo Sul do estado da Bahia (FreITAS et al 2008). Apesar de ser pouco conhecida em termos ecológicos, esta espécie é abundante localmente, facilmente coletada e apresenta uma etologia bastante explorada (FrEITAS et al 2008) sugerindo que ao contrário do padrão territorial e agressivo de outras espécies do gênero Trinomys e Proechimys (EMMONS \& FEER, 1997; NOWAK, 1999). T. i. denigratus apresenta comportamentos sociais mais tolerantes e próximos aos comportamentos altamente afiliativos da sua congênere (Fig. 2), o Trinomys yonenagae (FREITAS et al 2008). 
Trinomys yonenagae é um rato de espinho abundante e endêmico da área de dunas fixas do Médio São Francisco (RochA, 1995), mas que difere dos seus congêneres terrestres de floresta, pois habita uma área aberta e é semi-fossorial, portanto apresenta características derivadas ao restante do gênero. Devido a sua particular morfologia (ROCHA, 1995) e locomoção (RochA et al, 2007), o T. yonenagae é notavelmente convergente com outros roedores habitantes de sistemas de túneis e adaptados às áreas desérticas e semiáridas do mundo, tais como o ratocanguru (Dipodomys) e os ratos viscachas (Tympanoctomys barrarae) (SANTOS \& LACEY, 2011) que também apresentam hábito semi-fossorial.

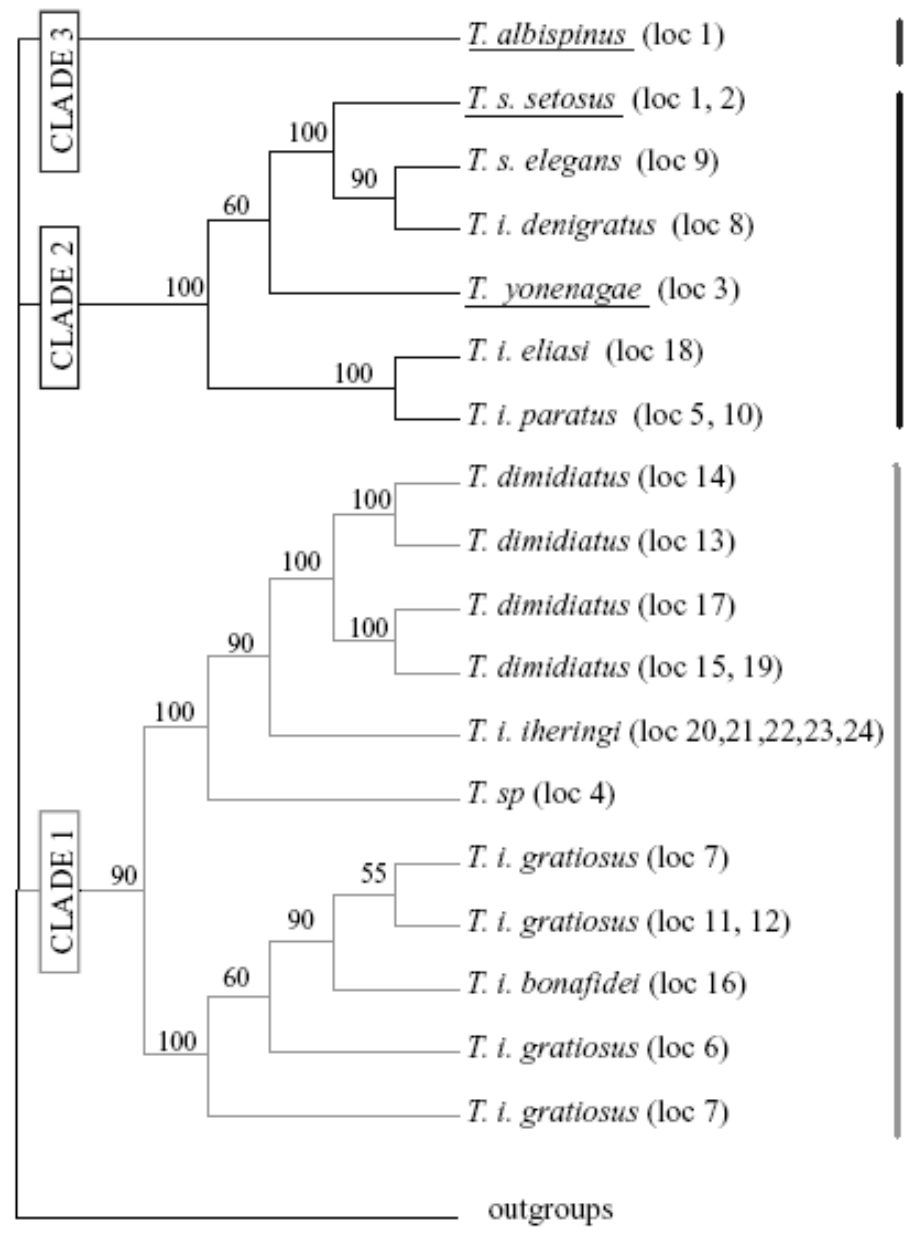

Figura 2. Filogenia proposta por Lara \& Patton (2000) baseada em análise bootstrap de 726 pares de bases de sequências de citocromo b, com destaque para três clados o gênero Trinomys: clado um (T. $i$. gratiosus, T. $i$. iheringi, T. i. dimidiatus), clado dois (T. i. eliasi, T. i. paratus, T. i. denigratus, T. yonenagae, T. setosus setosus, $T$. s. elegans) e Clado três (T. albispinus). 
Tendo em vista que (1) há evidências filogenéticas de que o gênero Trinomys seja um grupo monofilético (Leal-Mesquita et al 1992; Rocha 1995; Carvalho \& Salles 2004; GALEWSKI ET AL 2005), (2) que duas espécies T. yonenagae e T. i. denigratus deste clado (LARA \& PATton, 2000) vivam em regime seletivos distintos (semi-fossorial e terrestre) e (3) o gênero Clyomys apresenta características especializadas para vida fossorial, além de advir de um cladoirmão de Trinomys. Nós podemos considerar que a realização de um estudo comparativo entre espécies aparentadas (T. yonenagae e T. iheringi denigratus) comparadas com grupo externo (Clyomys bishopi) poderia revelar correlatos ecológicos da evolução do aumento e melhora do aprendizado e da memória espacial na linhagem.

Assim, caso o aumento da memória espacial fosse detectado nas espécies fossórias poderia representar uma homoplasia dentro dos equimídeos para este tipo de ecologia ligada a ambientes abertos e a vida fossorial, mas a falta de dados sistemáticos para estas três espécies inviabilizam essa conclusão. 


\section{OBJETIVO}

Este trabalho busca avaliar a cognição espacial (aprendizagem e memória espacial) de duas espécies de Trinomys (T. yonenagae, T. iheringi denigratus) e uma espécie de Clyomys (C. bishopi) em testes de aprendizado e memória espacial no labirinto complexo com o objetivo de entender a evolução destes traços em espécies de roedores terrestres, semi-fossórios e fossórios da família Echimyidae.

Para isso foi testada a hipótese de que espécies fossórias e terrestres diferem quanto ao nível de aprendizado e memória espacial. Portanto, caso a diferença seja significativa para as espécies, espera-se detectá-la naquelas espécies que sejam fossórias do que as terrestres. 


\section{MATERIAL E MÉTODOS}

\section{Animais capturados}

As capturas dos espécimes de roedores para as análises comportamentais estão de acordo com a legislação ambiental vigente (IBAMA 21034-2) e com a orientação do Comissão de Ética no uso de animais (CEUA) em pesquisa da FFCLRP/USP (Protocolo ${ }^{\circ}$ 09.1.1042.53.0).

Todos os animais usados foram adultos, para isso seguimos o critério do menor peso detectável em animal reprodutivamente maduro. Assim para T. yonenagae foram utilizados indivíduos com massa $\geq 90 \mathrm{~g}$, T. i. denigratus $\geq 200 \mathrm{~g}$ e Clyomys Bishop $\geq 200 \mathrm{~g}$.

Os T. yonenagae nasceram em cativeiro a partir de animais capturados nas dunas do Rio São Francisco, Vila de Ibiraba, município de Barra (1048’S; 4250’W), no bioma da Caatinga. O T. iheringi denigratus foi capturado em um remanescente de Mata Atlântica em estágio secundário de regeneração na Fazenda Oitinga, próximo $1 \mathrm{~km}$ do distrito de Camassandi, município de Jaguaripe (13 $00^{\circ}$ 'S $\left.38^{\circ} 01^{\prime} \mathrm{W}\right)$, no Bioma de Mata Atlântica. E o Clyomys bishopi foi capturado na área de campo de cerrado na Estação Ecológica de Itirapina $\left(22^{\circ} 13^{\prime} 09^{\prime}\right.$ S 4754'04” W), no município de Itirapina, do Estado de São Paulo.

Em cada localidade explorada, foram utilizados vários conjuntos de 25 armadilhas de captura-viva (Live-traps) (Aramefício Contrera, tipo Tomahawk, 30 x 15 x 15 cm), distribuídas em grades com cinco linhas de cinco armadilhas espaçadas em 10 metros uma da outra, Se possível, as armadilhas foram instaladas próximas aos locais com evidências da presença dos pequenos animais (tocas, abrigos, pegadas e fezes) com objetivo de aumentar o sucesso de captura. Cada conjunto de armadilhas foi colocado no máximo a 100 metros um do outro e demarcado com auxílio de aparelho de GPS (Garmin Vista $\mathrm{HCX}^{\mathrm{TM}}$ ). As armadilhas foram iscadas 
às $17 \mathrm{~h} 00 \mathrm{~min}$, com pedaços de abóbora ou fruta de cheiro forte e foram verificadas às $06 \mathrm{~h} 00 \mathrm{~min}$ (já que os animais são de hábito noturno). Os espécimes capturados foram sexados, pesados (balança da marca Pesola) e medidos (paquímetro Hélios extra Germany). Após a captura eles foram mantidos para habituação ao cativeiro e ajuste do ciclo circadiano por no mínimo 30 dias no laboratório, no recinto da FFCLRP-USP (LECO), sob condições de temperatura constante $\left(24-26^{\circ} \mathrm{c}\right)$, regime de claro e escuro invertido de $12 \mathrm{~h} / 12 \mathrm{~h}$, em gaiolas individuais (Sogorb; 34x40x16cm) e com água e comida (ração p/ hamster e frutas) ad libitum.

\section{Aparato experimental}

O labirinto complexo (conforme modelo de KIMCHI \& TERKEL, 2001) foi montado em uma caixa $(1,50 \mathrm{~m} \times 1,10 \mathrm{~m} \times 0,20 \mathrm{~m})$ com paredes e piso em compensado tipo MDF (15 mm de espessura) na cor branca, que foi coberto com tela de arame. No interior do labirinto havia paredes de $20 \mathrm{~cm}$ de altura compondo sete caminhos de oito $\mathrm{cm}$ de largura sendo seis cegos e um caminho (Fig. 3) que levavam à saída acoplada a um dispositivo com porta de fechamento automático, semelhante à armadilha do tipo Sherman (CxAxL: 30x9x8 cm), na qual foi colocada uma recompensa alimentar (ex: pedaço de maçã). A porta se fechava após a entrada do animal e nesse momento o teste era encerrado.

O labirinto ficou disposto no chão em uma sala de paredes sem qualquer tipo de marcação visual. Este procedimento visa garantir a eliminação das pistas visuais externas ao labirinto. A iluminação do labirinto feita é feita por quatro pequenas lâmpadas vermelhas incandescentes $(5 \mathrm{w})$ dispostas no teto da sala.

Todas as sessões experimentais tiveram suas imagens e sons gravados, em câmeras de vídeo (LG GAC-PT1 color) controladas remotamente, que estavam afixadas no teto de modo a 
ter um ângulo de visão integral de todo o labirinto. As imagens captadas foram enviadas para um monitor e um gravador de DVD (Marca LG).

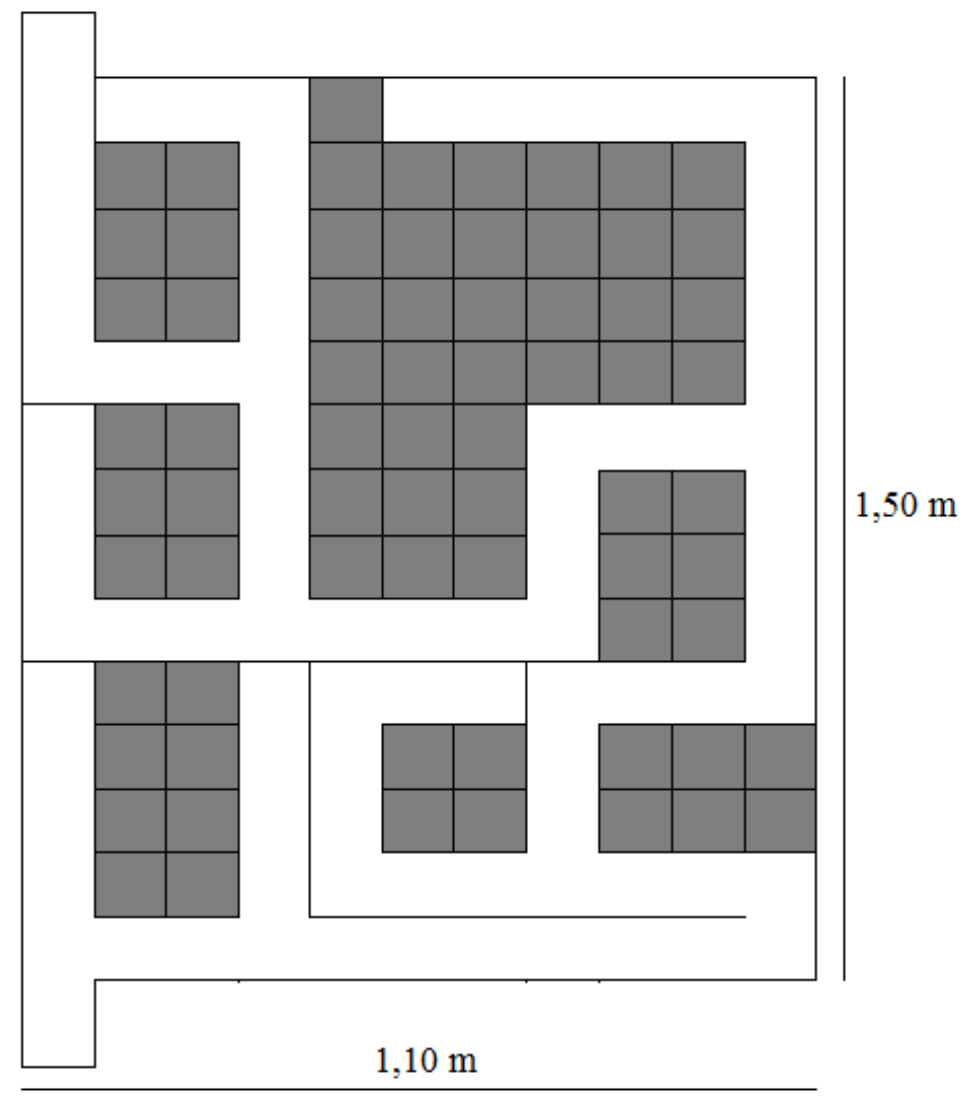

Figura 3. Desenho do labirinto complexo visto por cima $(1,50 \times 1,10 \times 0,20 \mathrm{~m})$ com seis caminhos errados e um correto.

\section{Fase pré-experimento}

Nas 24 horas anteriores ao experimento, cada indivíduo selecionado (por sorteio) para o procedimento foi separado em gaiola individual, onde recebeu uma quantidade de alimento equivalente à metade da sua necessidade diária (aprox. 5 gramas de ração NUVILAB) mais água ad libitum. Esse procedimento corresponde a uma privação parcial de alimento de maneira que 
os animais não percam entre 15 e $20 \%$ de sua massa corporal média (valor utilizado usualmente em estudos que utilizam a privação parcial).

Ao fim das 24 horas, o experimento foi iniciado e ao fim das cinco sessões experimentais diárias, o animal foi devolvido à gaiola, onde recebeu a mesma quantidade de alimento da fase de pré-experimento, esse procedimento durou três dias.

\section{Experimento de aprendizagem e memória}

Antes de cada experimento, o animal foi retirado da gaiola com ajuda de um tubo de PVC (75 mm de diâmetro) de $25 \mathrm{~cm}$ de comprimento, que foi encaixado na entrada do labirinto.

O experimento de aprendizagem espacial foi realizado no período de atividade do animal, que devido ao ciclo invertido, começou às $14 \mathrm{~h} 00 \mathrm{~min}$. A partir do momento que o animal saiu do tubo, a sessão foi iniciada. Cada animal teve 30 minutos para atingir a saída do labirinto, onde havia um dispositivo de saída com porta de fechamento automático e uma recompensa alimentar (pedaço de maçã). Os animais que não completaram o percurso foram substituídos por outro indivíduo, reiniciando uma nova sessão. Ao fim de cada sessão, o labirinto foi limpo com pano embebido em álcool 92\%.

Após o término da primeira sessão, o animal foi levado para entrada do labirinto via dispositivo de saída que foi encaixado na entrada. Este procedimento foi repetido nas quatro sessões subsequentes até completar cinco sessões diárias. Ao fim do dia de testes, o animal foi recolocado na gaiola, onde permaneceu sob restrição parcial de alimento até o dia seguinte. O mesmo procedimento foi repetido durante os próximos dois dias. 


\section{Variáveis mensuradas}

Para cada sessão gravada foram mensuradas as seguintes variáveis comportamentais:

(1) Tempo requerido até o fim do labirinto (TFL), medido em segundos;

(2) Número de erros cometidos (NER), cada erro consiste em um evento de tomar e percorrer a direção errada pelo animal.

Estas variáveis foram contabilizadas a partir da saída do tubo de entrada dos animais no labirinto, os dados obtidos foram utilizados para comparar aprendizagem e a retenção de memória entre as espécies testadas no labirinto complexo.

\section{Análise estatística}

As primeiras análises foram implementadas visando testar o desempenho por meio das variáveis TFL e NER das espécies ao longo dos 18 testes no labirinto, assim inicialmente testamos as seguintes hipóteses:

Há diferença no desempenho das espécies para as variáveis nos testes do labirinto?

Esta hipótese foi testada por uma ANOVA de um fator (Spp) para dados repetidos (testes) para cada variável (TFL e NER), seguido de teste de comparação múltipla $(\mathrm{p}<0,05)$.

\section{Aprendizagem}

A aprendizagem foi representada pela curva de aprendizagem montada a partir das médias de cada espécie por teste da variável TFL e NER, sendo em seguida comparadas visualmente. A taxa de aprendizagem (TA) foi calculada a partir da curva de cada indivíduo, aplicando a transformação recíproca $(1 / \mathrm{x})$ sobre os dados para linearizar e obter o "b" $(\mathrm{y}=\mathrm{bx}+$ 
a) do grau de inclinação de cada curva de aprendizagem. E o "b" corresponde a taxa de aprendizagem (TA). A média da TA de cada espécie foi testada tendo a seguinte hipótese:

Há diferença entre as taxas de aprendizagem (b) entre as espécies?

Esta hipótese foi testada por uma ANOVA de um fator (Sps) pela variável TA $(\mathrm{p}<0,05)$.

\section{Memória}

A memória foi avaliada em dois momentos dos testes realizados no labirinto: (1) entre os três dias dos testes de aprendizado, nos quais foi avaliada a memória-de-médio-prazo (duração em torno de $24 \mathrm{~h}$ pós-treinamento); (2) entre os três últimos testes $(16,17$ e 18) com intervalos de duração progressiva (2dias, 5 dias e 23dias) nos quais foram avaliados a memória-de-longoprazo.

O teste de memória de médio prazo avaliou o impacto do intervalo de 24 horas sobre o desempenho mensurado a partir das duas variáveis entre os três dias de testes, gerando a seguinte hipótese:

Há diferenças entre o desempenho do indivíduo no último teste de cada dia com o primeiro teste do dia seguinte?

Esta hipótese foi testada em Teste $\mathrm{T}$ para dados pareados $(\mathrm{p}<0,05)$ para cada Sp e Variável.

O teste de memória de longo prazo foi realizado com objetivo de avaliar a retenção do desempenho entre os progressivos intervalos de tempo (maiores que 24h) entres os três últimos testes $(16,17$ e 18). Para isso foi calculado a taxa de sucesso na retenção (IR) do desempenho p/ cada indivíduo, do fim da fase de aprendizagem com relação aos intervalos dos testes de memória ( 2 dias, 5 dias e 23 dias), utilizando a seguinte formula: IR = (Var_SS1Var_SSMem)/(Var_SS1-Var_SS15) (KIMCHI \& TERKEL 2001). O IR foi avaliado através da seguinte hipótese. 
Há diferença na taxa de sucesso das espécies em cada intervalo de tempo (2, 5 e 23 dias)? Que foi testada com uma ANOVA de um fator ( $\mathrm{Sp}$ ) sobre a variável IR para cada intervalo de tempo.

Os testes foram realizados no programa estatístico SPSS 13.0 for Window. 


\section{RESULTADOS}

Os testes foram realizados com 18 Trinomys yonenagae, 10 Trinomys iheringi denigratus e seis Clyomys bishopi.

\section{Aprendizagem}

Quando avaliados os 18 testes através da curva de aprendizagem de cada uma das três espécies plotadas num gráfico (Figura 4 (a) ), nota-se uma quase sobreposição das curvas e um desempenho no tempo até final do labirinto (TFL) muito próximo entre si para T. yonenagae e T.i. denigratus, por outro lado, os resultados dos primeiros cinco testes do Clyomys bishopi foram de valores médios relativamente mais baixos que os dois Trinomys, sugerindo que está espécie apresente tendência ao bom desempenho espacial no primeiro dia de aprendizado.

Com relação ao desempenho das espécies para as variáveis de TFL ao longo dos testes, o teste de ANOVA detectou diferença significativa entre os testes $(\mathrm{F}=8,86 ; \mathrm{P}<0,000)$, mas não na interação dos testes e espécies $(\mathrm{F}=0,85 ; \mathrm{p}=0,705)$, isso demonstra que houve alteração de desempenho ao longo do tempo, partindo de valores mais altos no teste inicial até valores mais baixos no teste 15 .

As curvas de aprendizado geradas pela variável número de erros cometidos (NER) (Figura 4 (b)) aparecem sobrepostas ao longo da maior parte dos testes, excetuando os testes 2, 10 e 18 na espécie Clyomys bishopi, cujos valores médios são mais baixos e sugerem que esta espécie teve um desempenho melhor que as duas espécies do gênero Trinomys. Quando testada a hipótese do desempenho ao longo dos testes em ANOVA, a análise detectou diferença significativa entre os testes $(F=3,65 ; p=0,000)$, mas não na interação dos testes e espécies $(\mathrm{F}=0,56 ; \mathrm{p}=0,979)$, portanto houve alteração de desempenho ao longo do tempo para o NER, assim como na variável TFL. 

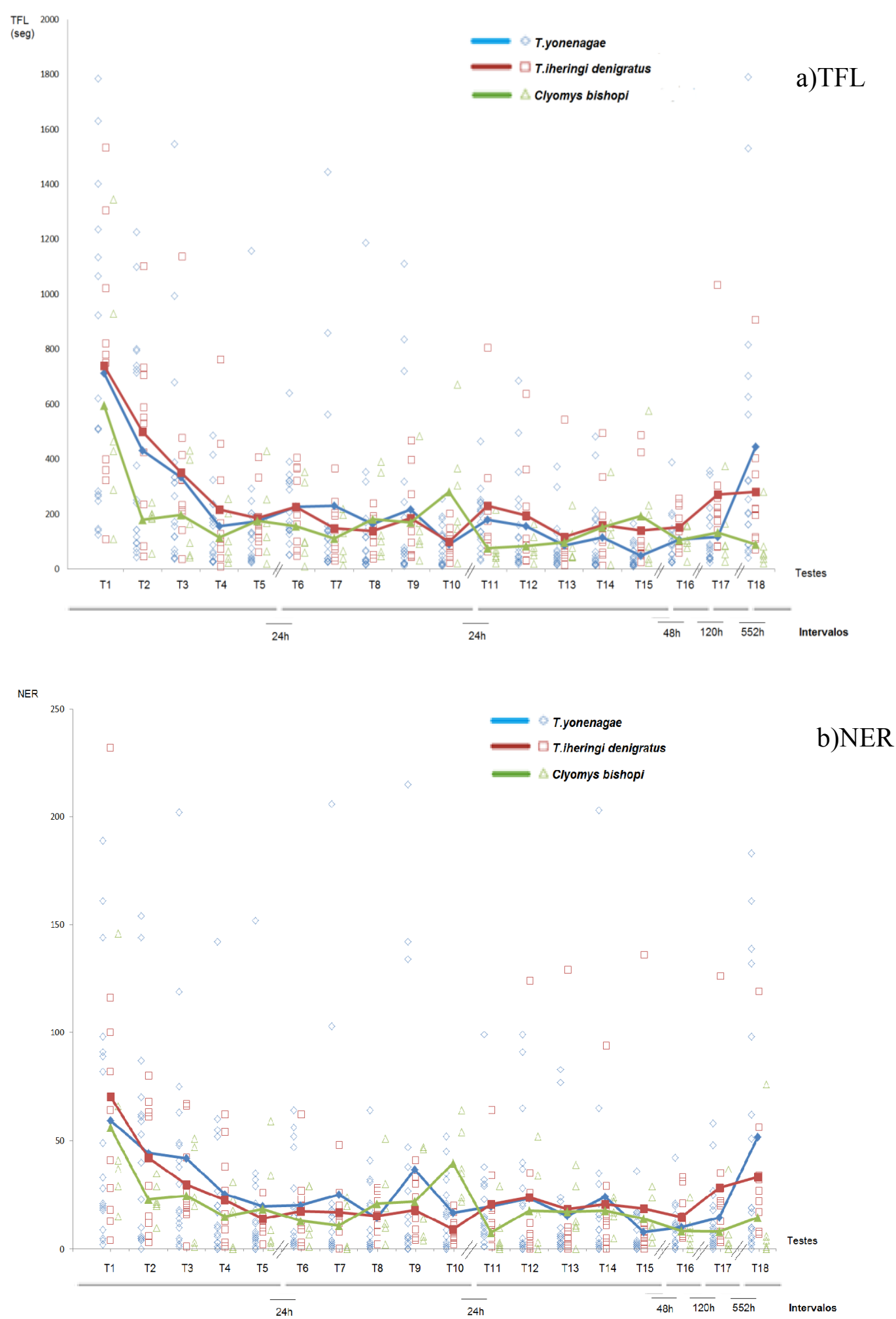

Figura 4. Curva das variáveis (a) tempo requerido até o final do labirinto (TFL) e (b) numero de erros cometidos expresso como valores individuais e médios em cada teste, em três espécies de rato-de-espinho. A, B e C representam cinco testes consecutivos de $30 \mathrm{~min}$ por dia realizados com intervalos de $24 \mathrm{~h}$. D, E e F representam testes únicos realizados com intervalo de 2dias (48h), 5dias (120h) e 23dias (552h) dias após C. . 
A taxa de aprendizagem (TA) obtida a partir da variável de TFL indicou segundo a dispersão dos pontos no gráfico (Fig. 5) que as espécies $T$ yonenagae e Clyomys bishopi apresentam valores médio e sua variância de TA sobrepostos, ao contrário de $T$. i. denigratus que apresenta valores menores. $\mathrm{O}$ teste de ANOVA revelou diferença marginalmente significativa $(\mathrm{F}=2,784 ; \mathrm{p}=$ 0,077) entre as espécies, sendo que T. yonenagae e Clyomys bishopi não apresentaram diferença entre eles e ambos diferiram do T. i. denigratus.

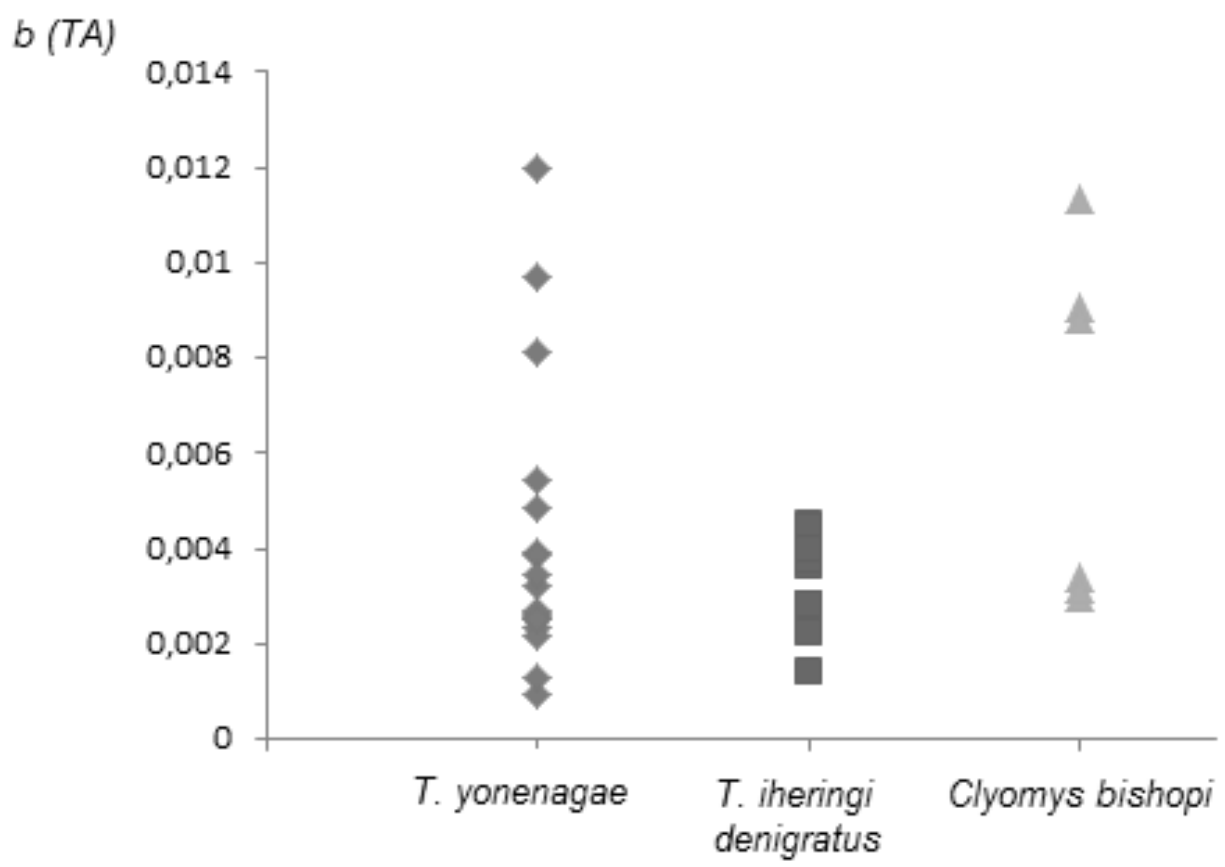

Figura 5. Taxa de aprendizagem (TA) obtida a partir do b da equação da curva para as espécies T. yonenagae, T.i.denigratus e Clyomys bishopi 


\section{Memória}

Para memória-de-médio-prazo (Fig. 6), tanto o $T$. yonenagae quanto o $T$. $i$. denigratus apresentaram aumentos nos valores de TFL medidos entre os testes 5 e 6 e os testes 10 e 11 . (teste inicial do dia e o teste final do dia anterior), sendo que foram detectadas diferenças significativas entre os testes 10 e 11 no $T$. yonenagae $(\mathrm{t}=-3,40 ; \mathrm{p}=0,003)$ e marginalmente significativa no $T$. $i$. denigratus $(\mathrm{t}=--2,03 ; \mathrm{p}=0,072)$. O Clyomys bishopi apresentou TFL que sofreu redução entre os testes 5 e 6 e os testes 10 e 11, mas sem apresentar resultados que demonstrassem diferença significativa $(t=0,18 ; p=0,858$ e $t=2,00 ; p=0,100)$. As espécies de mesmo gênero e mais próximas filogeneticamente apresentaram resultados próximos, estes resultados refletem em termo de memória, o impacto maior do intervalo de $24 \mathrm{~h}$, manipulação e inserção dos animais no primeiro teste de labirinto sobre estas duas espécies quando comparados com o Clyomys bishopi.

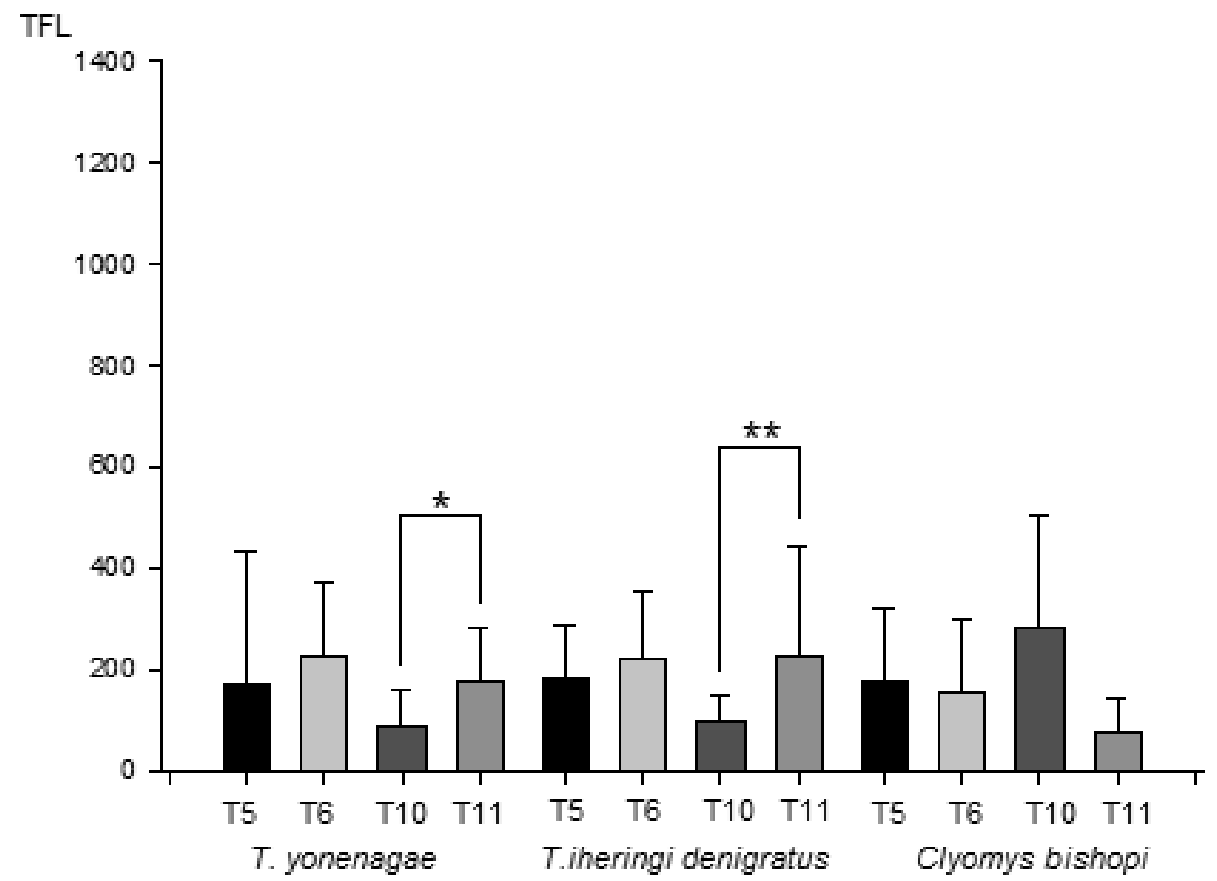

Figura 6. Média e erro padrão do TFL (tempo requerido para alcançar o fím do labirinto) entre os testes 5 e 6 e os testes 10 e 11 para cada espécie estudada, comparados através de teste $\mathrm{T}$ para dados pareados $(\mathrm{p}<0,05) *=$ significância estatística;** marginalmente significativo. 
Quanto à memória de médio prazo (Fig. 7) avaliada em relação ao número de erros (NER) foi demonstrado um resultado oposto ao TFL. O T. yonenagae não apresentou valores de NER que pudessem representar diferença significativa entre os testes 5 e $6(t=-0,065 ; p=0,948)$ e 10 e 11 $(t=-0,483 ; p=0,635)$ e assim ficou demonstrado que para essa variável o intervalo de $24 \mathrm{~h}$ não levou alteração na memória. O T.i. denigratus apresentou resultado semelhante ao teste com TFL, com os valores de NER tendendo ao aumento entre os testes mas sem apresentar diferença significativa para os testes 5 e $6(\mathrm{t}=-0,615 ; \mathrm{p}=0,553)$ e 10 e $11(\mathrm{t}=-1,870 ; \mathrm{p}=0,094)$, por outro lado, o Clyomys bishopi apresentou a tendência de redução dos valores de NER entre os testes 5 e $6(t=0,442 ; p=0,676)$ e 10 e $11(t=3,558 ; p=0,016)$ sendo esta significativa.

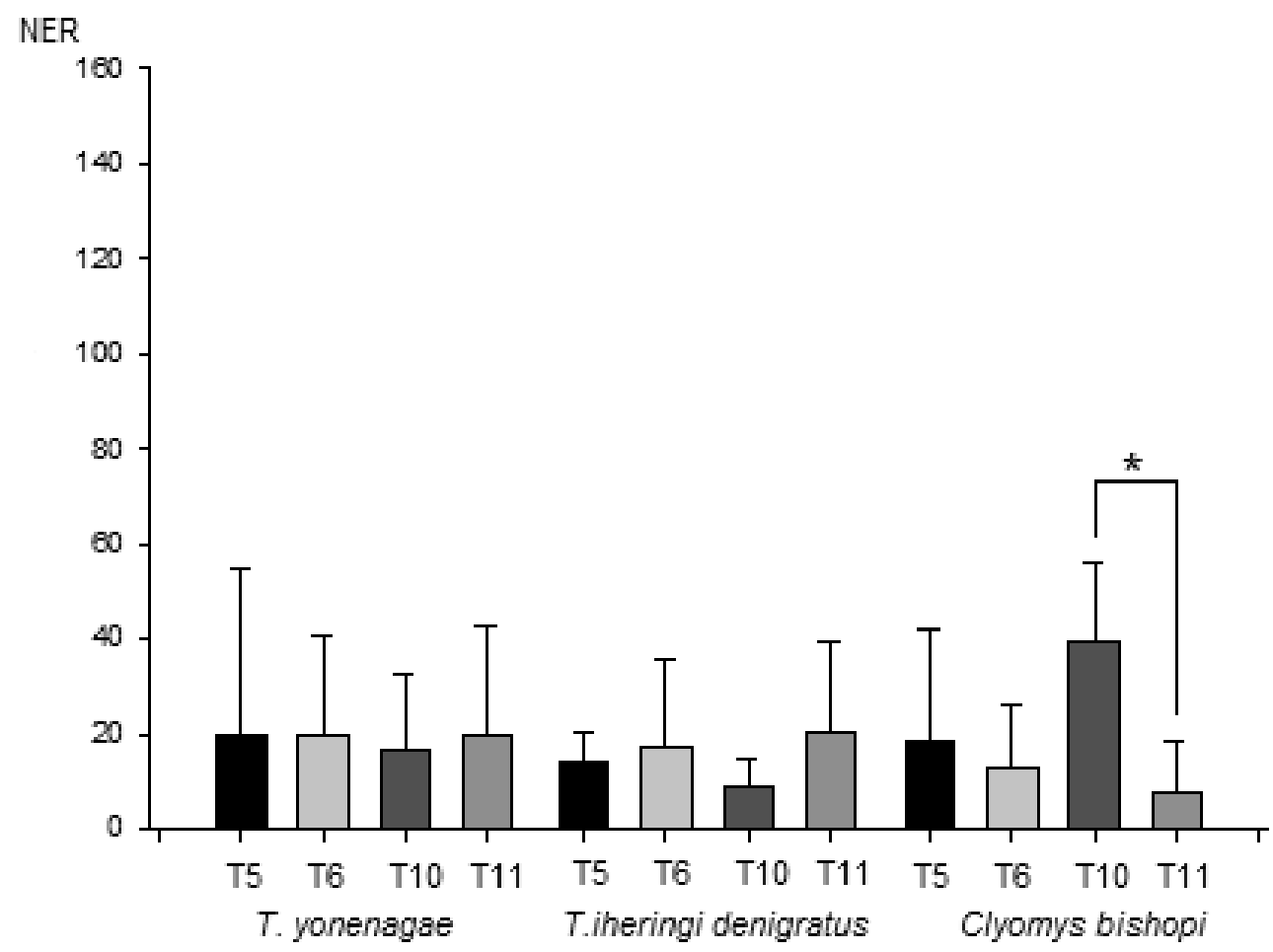

Figura 7. Média e erro padrão do NER (número de erros cometidos) entre os testes 5 e 6 e os testes 10 e 11 para cada espécie estudada, comparados através de teste $\mathrm{T}$ para dados pareados $(\mathrm{p}<0,05) *=$ significância estatística. 
A memória de longo prazo foi mensurada pela variável do índice de retenção (IR) sobre as duas variáveis medidas. Para a variável do TFL (Figura 8), os valores de IR diminuíram ao longo dos testes sem ficar demonstrado uma diferença significativa entre as espécies. Pelo teste de ANOVA ficou demonstrado que não há diferença significativa entre as espécies para os diferentes tempos de reteste: 2 dias $(F=0,111 ; p=0,894) ; 5$ dias $(F=0,364 ; p=0,697)$ e 23 $\operatorname{dias}(\mathrm{F}=0,964 ; \mathrm{p}=0,392)$.

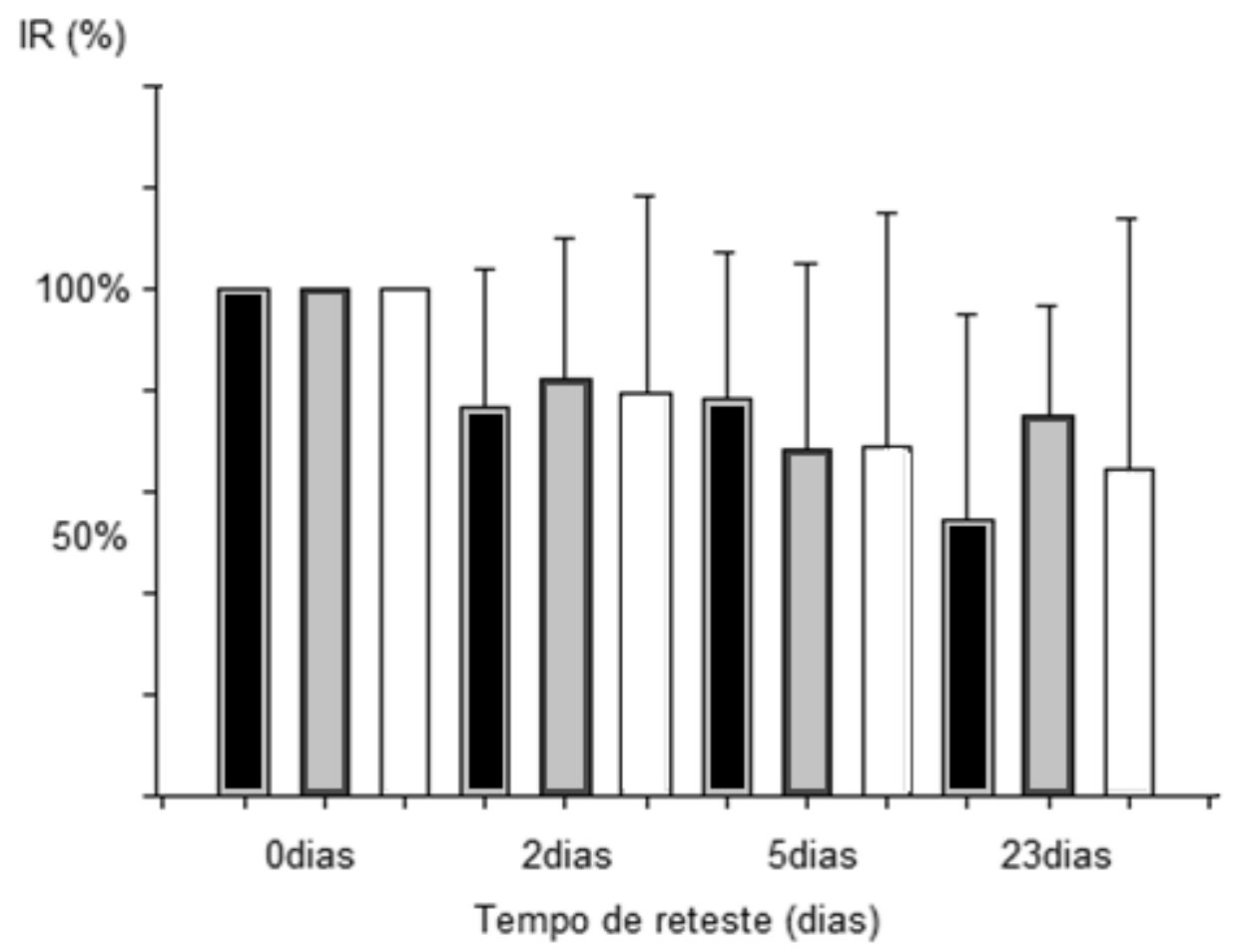

Figura 8. Índice de retenção (IR) médio + erro padrão (intervalos de 2, 5, 23 dias após fim da aprendizagem) calculados a partir do TFL do T. yonenagae (preto), T. i. denigratus (cinza) e Clyomys bishopi (branco).

Para a variável do NER, os valores diminuíram ao longo dos testes para todas as espécies, mas em Clyomys bishopi a retenção do desempenho dado pelo IR foi maior que as espécies do gênero Trinomys, mas o teste de ANOVA não detectou diferença significativa entre as espécies para os diferentes tempos de reteste: 2 dias $(F=0,735 ; p=0,487) ; 5$ dias $(F=0,818 ; p=0,450)$ e 23 $\operatorname{dias}(\mathrm{F}=0,981 ; \mathrm{p}=0,386)$ (Figura 9). 


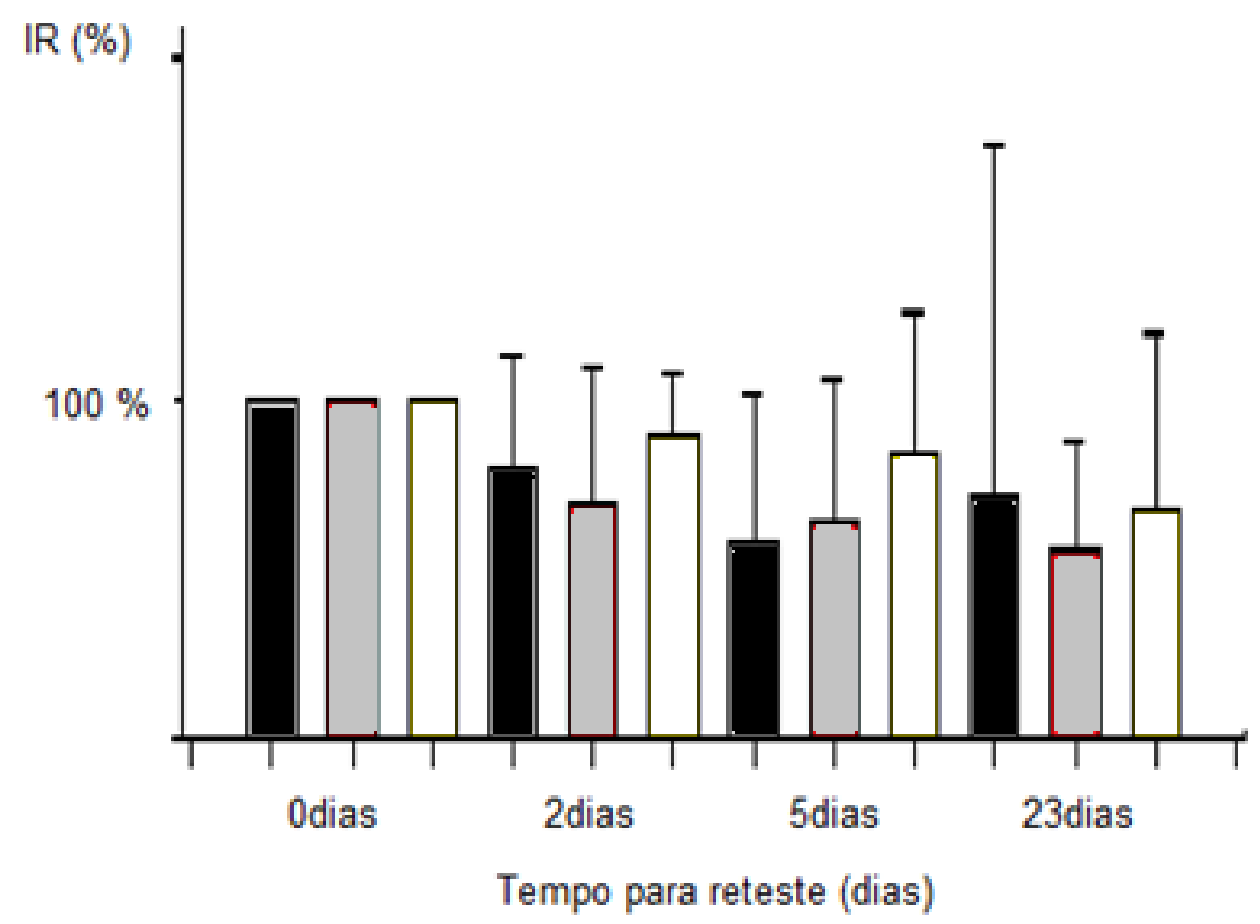

Figura 9. Índice de retenção (IR) médio + erro padrão (intervalos de 2, 5, 23 dias após fím da aprendizagem) calculados a partir do TFL do T. yonenagae (preto), T. i. denigratus (cinza) e Clyomys bishopi (branco).

Com relação à memória, o desempenho das espécies não foi suficiente para diferencia-las, apesar dos dados apontarem para uma redução do índice de retenção ao longo do tempo. Em suma, dentre as três espécies, o Clyomys bishopi se destaca por valores de TFL e NER menores que as outras duas espécies congêneres, mas não a ponto de resultar em uma diferença significativa. 


\section{DISCUSSÃO}

A ecologia e o uso do habitat podem ter peso importante na causação da variação ecomorfológica e comportamental de espécies filogeneticamente próximas, por outro lado quando o sinal filogenético é forte, ele pode contrabalançar os efeitos do regime seletivo sobre a evolução de uma espécie em relação às espécies aparentadas (PAGEL 1999). Essas duas interpretações podem explicar os resultados apresentados neste trabalho. No entanto este trabalho foi um estudo comparativo que contou com apenas três espécies e esta amostra de espécies é pouco representativa para se testar o sinal filogenético nos dados, entretanto na maioria dos estudos comparativos filogenéticos, o sinal fillogenético está presente, ou seja, a variação do que foi mensurado entre as espécies é explicado pela estruturação da filogenia (BLOMBERG ET AL 2003), Com base nisso, é possível que os resultados mais esperados sejam aqueles em que as espécies mais próximas entre si apresentem resultados mais similar entre si para a variação do caractere do que as espécies mais distantes filogeneticamente, assim a partir das nossas espécies seria mais esperado encontrarmos que as espécies do gênero Trinomys (T.i.denigratus e $T$. yonenagae) apresentassem resultados mais próximos entre si que a espécie Clyomys bishopi que faz parte de um clado irmão do gênero Trinomys (FABRE et al 2012), caso o sinal filogenético estivesse presente. A hipótese nula para o sinal filogenético seria resultado da evolução do caractere em resposta a pressão seletiva do meio ou sexual.

Inicialmente pelas curvas de aprendizagem, nos apontaríamos para a direção de uma inércia filogenética entre as duas espécies do gênero Trinomys, que são do mesmo clado na filogenia do seu gênero Trinomys (LARA \& PATTON 2000). Este resultado repete o que já foi estudado para ao grau de sociabilidade (FREITAS et al 2008) no qual as mesmas espécies de Trinomys utilizadas aqui não diferiram quanto ao índice de afiliação e fisiologia (BARROS et al 1998) assim parece 
que em termos de aprendizado espacial, o sinal filogenético parece ter um peso na manutenção de exaptações cognitivas espaciais entre as espécies T. yonenagae e T. iheringi denigratus, mesmo ser for levado em conta que a condição de vida em áreas aberta e do hábito semifossorial do T. yonenagae sejam distintos em relação a regime seletivo ancestral de floresta. Apesar das primeiras análises das curvas de aprendizado não apontarem para diferenças significativas entre as três espécies, os resultados do Clyomys bishopi, a espécie mais especializada para vida fossorial, apresenta uma tendência de melhora no desempenho inicial, referente ao primeiro dia de testes de aprendizagem, talvez a manutenção desta tendência ocorra em função de uma amostragem maior. $\mathrm{O}$ aparecimento de mais pontos abaixo da média por teste pode ser importante para demonstrar que a tendência é real para o Clyomys bishopi em termos de desempenho inicial no aprendizado. Em relação ao trabalho de KiMCHI \& TERKEL (2001) que utilizou labirinto complexo com mesmo desenho de caminhos com o rato-toupeira Spalax ehrenbergi, Rato Wistar Rattus novergicus e vole Microtus guentheri foi observado que no teste inicial que o S. ehrenbergi levou mais tempo em média que o R. norvegicus e o M. guentheri. O S. ehrenbergi é a espécie mais especializada em relação à vida subterrânea e levou mais tempo, ao contrário do nossos resultados que colocaram a espécie fossorial Clyomys bishopi como a espécie mais rápida no primeiro teste que as duas espécies de Trinomys. Este resultado pode refletir as diferenças morfológicas quanto o deslocamento entre as espécies $C$. bishopi e $S$. ehrenbergi no labirinto, pois o $S$. ehrenbergi, devido as suas características sensoriais que favorecem a escavação teria um deslocamento mais lento no labirinto complexo (Kimchi \& Terkel 2004) enquanto que o Clyomys bishopi, numa morfologia intermediária entre um animal terrestre e subterrâneo teria um deslocamento menos pausado e mais rápido. Ainda com relação à curva de aprendizagem, neste trabalho e no trabalho de Kimchi \& Terkel (2001) todas as 
espécies tenderam apresentar valores cada vez mais baixo à medida que os testes foram repetidos seguindo o que é esperado para uma curva de aprendizagem.

A taxa de aprendizagem é uma medida direta da curva de aprendizagem e mais fina da complexidade do aprendizado em labirinto complexo, neste trabalho o T. yonenagae, juntamente com o Clyomys bishopi apresentou valores próximos com sobreposição de suas variâncias, cujo teste estatístico detectou uma diferença marginalmente significativa, que dada ampla variância dos dados do T. yonenagae, nos poderíamos interpretar como sendo realmente significativa, Em vista disto é provável que o efeito da pressão seletiva do ambiente aberto e do estilo de vida fossorial gere demandas semelhantes e importantes para aumento da taxa de aprendizagem no T.yonenagae e Clyomys bishopi. Apesar do $\mathrm{p}$ estatístico ser marginalmente significativo, podemos sugerir que nesta variável, o efeito da filogenia pode ter cedido ao peso da pressão seletiva dos hábito fossorial e o ambiente aberto que são fatores importantes na seleção do aumento da aprendizagem e da memória espacial, este fator pode ser observado em ratostoupeira do gênero S. ehrenbergi que quando comparados com voles (Microtus) e rato-de laboratório apresentaram resultados diferentes que indicaram melhor desempenho espacial em labirinto complexo (KIMCHI \& TERKEL 2001), apesar das espécies no referido trabalho serem de famílias distintas dentro de Rodentia o que poderia favorecer um grau de diferenciação maior e um sinal filogenético baixo para o aprendizado e a memória espacial.

Dentre as três espécies equimídeos avaliadas, O Clyomys bishopi se destacou nos testes de memória de médio prazo, no tempo até o fim do labirinto (TFL), enquanto que $T$. iheringi denigratus e T.yonenagae apresentaram aumento dos tempos entre o segundo e o terceiro dia de teste de aprendizagem, o Clyomys bishopi que é fossorial apresentou redução no tempo que apesar de não foi significativa, mostrou um tendência não observada nas duas espécies que 
descendem de um grupo mais terrestre de superfície. Já no número de erros cometidos (NER) que é uma variável mais direta do quão é eficiente é a espécie em utilizar o espaço, O C. bishopi apresentou redução significativa no NER entre o segundo e terceiro dia dos testes de aprendizagem, sugerindo uma habilidade espacial melhorada neste quesito em relação aos Trinomys.

$\mathrm{Na}$ memória de longo prazo ficou demonstrado que apesar da grande variação entre os indivíduos e a não-significância das variações entre as espécies, o C. bishopi apresentou uma tendência a manter o desempenho entre as espécies e apresentar ao fim do experimento o tempo e o número de erros mais baixo que as espécies do gênero Trinomys. Assim como o subterrâneo Spalax ehrenbergi se sobressaiu em relação aos desafios cognitivos espaciais com outras espécies de hábito epígeo (KIMCHI \& TERKEL 2001), é provável que o estilo de vida fossorial do C. bishopi seja um fator importante para melhoria observada nos nossos testes, uma vez que esta espécie apresenta uma série de adaptações associadas ao regime seletivo de área aberta e vida em tuneis subterrâneos, como corpo coberto por pelagem espinhosa, cauda de tamanho reduzido, membros curtos e garras dianteiras robustas (BISHOP, 1974 APUD BEZERRA \& OLIVEIRA, 2010). Entretanto não podemos subestimar a versatilidade das espécies que conseguem viver em dois nichos distintos como o epígeo e hipógeo. O T. yonenagae é uma espécie que se destaca por ter hábito semi-fossorial que no seu gênero é possivelmente derivado assim como habitar o bioma caatinga, mas especificamente as dunas do médio São Francisco que é totalmente distinto da Caatinga strictu sensu em relação ao ambiente ancestral do gênero, onde suas populações fazem o uso de tocas subterrâneas como abrigo e forrageiam na superfície (RocHA 1995; SANTOS \& LACEY 2009). 
Um das discussões mais comuns dentro da neuroecologia é com relação às bases neurobiológicas da cognição espacial mais precisamente se a relação das funções cognitivas com relação ao tamanho do encéfalo como um todo e de partes específicas. Ao se explorar dados da literatura sobre encefalização de espécies de roedores utilizadas neste trabalho (RIBEIRO 2004) com relação à encefalização das nossas espécies teríamos os valores de T. yonenagae $>$ T. $i$. denigratus $>$ Clyomys bishopi, enquanto que com relação ao aprendizado e a memória espacial teríamos resultados que contrariam este ordem, mostrando C. bishopi e T. yonenagae com resultados de aprendizado mais próximos entre si que com $T$. $i$. denigratus e $C$. bishopi com desempenho de memória de curto prazo melhor que T. i. denigratus e T. yonenagae. Enfim a relação tamanho do encéfalo como um todo não se mostraria nos resultados de cognição espacial. E esse resultado seria compatível com a hipótese da evolução em mosaico do encéfalo (BARTON \& HARVEY 2000) ao invés da hipótese da evolução coordenada do encéfalo (FINLAY \& DARLINGTON 1995)

Assim partes específicas do encéfalo poderiam está relacionadas com funções cognitivas específicas. A descoberta da relação da memória espacial com áreas localizadas no encéfalo tais como o hipocampo, a partir da teoria do mapa cognitivo por O'keefe \& Nadel (1978) deu impulso a uma série de trabalhos com esta temática. Dentre esses podemos destacar os estudos com pássaros estocadores e não estocadores demonstraram que o hipocampo era maior nos primeiros que nos segundos (Krebs et al, 1989; Pravosudov \& Clayton, 2002; Sherry ET AL, 1992; SHERRY, 2006). Assim como, as diferenças inter-sexuais no uso do espaço em roedores (JACOBS ET AL, 1990; JACOBS \& SPENCER, 1994) onde machos diferem de fêmeas e sua variação ao longo do ano de acordo com a fase reprodutiva (LAVENEX et al 2000). Além disso, o elo entre memória espacial e a função hipocampal em pássaros (ex, HAMPTON \& SHETTLEWORTH, 1996; 
SHERRY \& VACCARINO, 1989) e mamíferos (WILSON \& MCNAUGHTON, 1993) incluindo humanos (EKSTROM et al, 2003) permite estudos comparativos que podem conduzir para novos insights sobre as bases neurobiológicas dos comportamentos espaciais.

Portanto conjecturamos, em termos de estudo comparativo, a avaliação de mais espécies de habitat e uso do habitat distintos, tais como, as espécies subterrâneas do gênero Ctenomys, que são é caviomorfos e apresentam dezenas de espécies, que já tiveram algumas espécies estudadas, sem comparar com outras espécies de ecotipos diferentes (ANTINUCHI \& SCHLEICH 2003), mas que deveriam ser incorporadas a novos estudos que permitissem a aplicação de métodos comparativos filogenéticos para testar hipóteses evolutivas de adaptação e exaptação. Em relação ao estudo neuroetológico, poderíamos sugerir a investigação de áreas especificas do encéfalo como o tamanho do hipocampo e sua relação com a cognição espacial, aplicando técnicas de histologia e estereologia que são bastante utilizadas na avaliação do tamanho da partes encefálicas de interesse (GUNDERSEN \& JENSEN 1987), atualmente técnicas de imagem do encéfalo permitem investigar in vivo o seu funcionamento, composição e tamanho permitindo testar diversas hipóteses neuroecológicas num grau de refinamento maior do que numa avaliação do tamanho como todo (UlLMANN ET AL 2010). 


\section{REFERÊNCIAS BIBLIOGRÁFICAS}

ABLE, K.. P. Mechanisms of orientation, navigation, and homing. In: GAUTHREAUX S.A. (Orgs.), Animal Migration, Orientation, and Navigation, . New York: Academic Press, pp. 283-373, 1980.

AGUILERA, M. Population ecology of Proechimys guairae (Rodentia: Echimyidae). Journal of Mammalogy, 80: pp. 487-498, 1999

ANTINUCHI, C. D.; SCHLEICH, C. E. Spatial memory in a solitary subterranean rodent Ctenomys talarum (Rodentia: Ctenomyidae). Belg. J. Zool. 133(1): pp. 89-91, 2003.

BARROS, R. C. H.; ABE, A. S.; CÁRNIO, E. C.; BRANCO, L. G. S. Regulation of breathing and body temperature of a burrowing rodent during hypoxic-hypercapnia.. Comparative Biochemistry and Physiology, Part A, 138: pp. 97- 104, 2004.

BARROS, R. C. H.; OLIVEIRA, E. S.; ROCHA, P. L. B.; BRANCO, L. G. S. Respiratory and metabolic responses of the spiny rats Proechimys yonenagae and $P$. iheringi to $\mathrm{CO} 2$. Respiratory. Physiology, 111: pp. 223-231, 1998.

BARTON, R. A.; PURVIS, A.; HARVEY, P. H. Evolutionary radiation of visual and olfactory brain systems in primates, bats and insectivores. Philosophy Transactions of the Royal Society London B, 348: pp. 381-392, 1995.

BARTON, R. A. Visual specialisation and brain evolution in primates. Philosophy Transactions of the Royal Society London,265: pp. 1933-1937, 1998.

BARTON, R. A.; HARVEY, P. H. Mosaic evolution of brain structure in mammals. Nature, 405: pp. 1055-1058, 2000.

BAUM, D. A.; LARSON, A. Adaptation reviewed: a phylogenetic methodology for studying character macroevolution. Syst. Zool. 40: pp. 1-18, 1991. 
BEGALL, S.; BURDA, H.; SCHLEICH, C. E. Subterranean Rodents: News from Underground.In: BEGALL, S.; BURDA, H.; SCHLEICH, C. E. (Orgs.). Subterranean Rodents: News from Underground. Berlin Heidelberg: Springer-Verlag. Pp. 3-9, 2007.

BERGALLO, H. G. Ecology of a small mammal community in a Atlantic Forest area in southeastern Brazil. Studies in the Neotropical Fauna Environmental. 29: pp. 197-217, 1994.

BERGAllo, H. G. Comparative life-history characteristics of two species of rats, Proechimys iheringi and Oryzomys intermedius, in an Atlantic Forest of Brazil. Mammalia, 59: pp. 51—64, 1995.

BEZERRA, A. M. R.; OLIVEIRA, J. A. Taxonomic implications of cranial morphometric variation in the genus Clyomys thomas, 1916 (rodentia: echimyidae). Journal of Mammalogy, 91 (1): pp. 260-272, 2010.

BOULHUIS, J. J.; MACPHAIL. E. M. A critique of the neuroecology of learning and memory. Trends Cogn Sci, 5: pp. 426-433, 2001.

BOULHUIS, J. J. 2005. Function and mechanism in neuroecology: looking for clues. Animal Biology, 55 (4): pp. 457- 490

BUDEAU, D. A..; VERTS, B. J. Relative brain size and structural complexity of habitats of Chipmunks. J. Mammal. 67, pp. 579-581, 1986.

CARRILLO-MORA, P.; GIORDANO, M.; SANTAMARIA, A. Spatial memory: Theoretical basis and comparative review on experimental methods in rodents. Behavioral Brain Research, 203: pp. 151-164, 2009.

CARVAlHO, G. A. S.; SALleS, L. O. Relationships among extant and fossil echimyids (Rodentia: Hystricognathi). Zoology Journal of. Linnean Society, 142: pp. 445 477, 2004.

CHANGIZI, M. A. Relationship between number of muscles, behavioral repertoire size, and encephalization in mammals. J. Theor. Biol. 220, pp. 157-168, 2003. 
CLUTTON-BROCK, T. H.; HARVEY, P. H. Comparative approaches to investigating adaptation. In Behavioral ecology: an evolutionary approach. Edited by J R Krebs and N B Davies. Blackwell Scientific Publications, Oxford. pp. 7 - 29, 1984.

CODDINGTON, J. A. 1988. Cladistic tests of adaptional hypotheses. Cladistics, 4: pp. 3 -22, 1988.

EISENBERG, J. F, WILSON, D. E. Relative brain size and feeding strategies in the chiroptera. Evolution. 32: pp.740-751, 1978.

EISENBERG, J. The mammalian radiations: analysis of trends in evolution, adaptation, and behaviour. Chicago: The University of Chicago Press; 1981.

EISENBERG, J. F.; REDFORD, K. H. Mammals of the Neotropics - The Central Neotropics, Vol. 3. Chicago: The Univ. of Chicago Press, 1999.

EKSTROM, A. D.; KAHANA, M.. J.; CAPLAN, J. B.; ISHAM, E.; FIELDS, T.A.; ISHAM, E.; NEWMAN, E.; FRIED, I. Cellular networks underlying human spatial navigation. Nature, 425: pp. 184-187, 2003.

EMMONS L. H. Ecology of Proechimys (Rodentia, Echimyidae) in Southeastern Peru. Trop Ecol 23: pp. 280-290, 1982.

EMMONS, L. H.; FEER, F. Neotropical Rainforest Mammals - A Field Guide, 2nd ed. Chicago: The Univ. of Chicago Press, 1997.

FABRE, P. H., HAUTIER, L., DIMITROV, D., DOUZERY, E. J. P. A glimpse on the pattern of rodent diversification: a phylogenetic approach. BMC Evo Biol 12:88, 2012.

FINLAY, B. L.; DARLINGTON, R. B. Linked regularities in the development and evolution of mammalian brains. Science 268: pp. 1578-1584, 1995. 
FLEMING, T. H. Population ecology of three species of Neotropical rodents. Misc. Publ. Mus. Zool. Univ.Mich, 143: pp. 1-77. 1971.

FRAHM, H. D.; REHKAMPER, G.; NEVO, E. Brain structure volumes in the mole rat, Spalax ehrenbergi (Spalacidae, Rodentia in comparison to the rat and subterrestrial insectivores. J. Hirnforsch, 38: pp. 209-222, 1997.

FREITAS, J. N. S.; EL-HANI, C. N.; ROCHA, P. L. B. Affiliation in four Echimyid rodent species based on intrasexual dyadic encounters: evolutionary implications. Ethology, 114: 389397, 2008.

FREITAS, J. N. S.; CARVALHO, A. S.; EL-HANI, C. N.; ROCHA, P. L. B. Affiliation in the social interactions in captivity of the torch tail rat, Trinomys yonenagae (Rodentia: Echimyidae). Journal of Ethology, 28: pp. 105-112, 2009

GAlEWSKI, T.; MAUfFREY, J. F.; LEITE, Y. L. R.; PATTON, J. L.; DOUZERY, E. J. P. Ecomorphological diversification among South American spiny rats (Rodentia; Echimyidae): a phylogenetic and chronological approach. Molecular Phylogeny Evolution. 34: pp. 601-615. 2005.

GAULIN, S. J. C. \& FITZGERALD, R. W. Sexual selection for spatial-learning ability. Animal Behaviour, 37: pp. 322-331, 1989.

GROVE, M. Orbital dynamics, environmental heterogeneity, and the evolution of the human brain. Intelligence. 40: pp. 404-418, 2012.

GUNDERSEN, H. J. G.; JENSEN, E. B. The effciency of systematic sampling in stereology and its prediction. J Microsc. 147:229-263, 1987.

HAMPTON, R.R.; SHETTLEWORTH, S.J. Hippocampal lesions impair memory for location but not color in passerine birds. Behavioral Neuroscience, 110: 831-835, 1996.

HARVEY, P. H.; PAGEL, M. D. The comparative method in evolutionary biology. Oxford University Press, Oxford, 1991. 
HONEYCUTT, R. L.; FRABOTTA, L. J.; ROWE, D. L. Rodent Evolution, Phylogenetics, and Biogeography: Wolff, J. O., Sherman, P. W (eds). Rodent Societies: An Ecological \& Evolutionary perspective. The University of Chicago Press. Chicago and London, 2007.

HUCHON, D.; DOUZERY, E. J. P. From the Old World to the New World: A molecular chronicle of the phylogeny and biogeography of Hystricognath rodents. Molecular Phylogenetics and Evolution, 20: pp. 238-251, 2001.

IWANIUK, A. N., DEAN, K. M. \& NELSON, J. E. A mosaic pattern characterizes the evolution of the avian brain. Proceedings of the Royal Society London B. 271: pp. S148-S151, 2004.

JACOBS, L. F.; GAULIN, S. J.; SHERRY, D. F.; HOFFMAN, G. E. Evolution of spatial cognition: sex-specific patterns of spatial behavior predict hippocampal size. Proceedings National Academy Science USA 87: pp. 6349-6352, 1990.

JACOBS, L. F.; SPENCER, W. D. Natural space-use patterns and hippocampal size in kangaroo rats. Brain Behavioral Evolution, 44:125-132, 1994.

KAAS, J. H.;COLLINS, C. E. Variability in the sizes of brain parts. Behavioral. Brain Science, 24: 288-290, 2001.

KIMCHI, T.; TERKEL, J. Spatial learning and memory in the blind mole rat (Spalax ehrenbergi) in comparison with the laboratory rat and Levant vole. Animal Behavior,61: pp. 171-180, 2001.

KIMCHI, T.; TERKEL, J. Comparison of the role of somatosensory stimuli in maze learning in a blind subterranean rodent and a sighted surface-dwelling rodent. Behavioural Brain Research, 153: pp. 389-395, 2004.

KREBS, J. R.; SHERRY, D. F.; HEALY, S. D.; PERRY, H.; VACCERINO, A. L. Hippocampal specialization of food-storing birds. Proc Nat Acad Sci USA, 86: pp. 1388-1392, 1989.

LARA, M. C.; PATTON, J. L. Evolutionary diversification of spiny rats (genus Trinomys, Rodentia: Echimyidae) in the Atlantic Forest of Brazil. Zoology Journal. Linnean. Society. 130: pp. 661-686, 2000. 
LARSON, A.; LOSOS, J. B. Adaptation. In Phylogenetic systematics of adaptation. Edited by M. R. ROSE; G. V. LAUDER. Academic Press, San Diego. pp. 187-220, 1996.

LAVENEX, P.; STEELE, M. A.; JACOBS, L. F. Sex Differences, but No Seasonal Variations in the Hippocampus of Food-Caching Squirrels: A Stereological Study. The journal of comparative neurology, 425: pp. 152-166. 2000.

LEAL-MESQUITA, E. R.; YONENAGA-YASSUDA, Y.; ROCHA, P. L. B. Chromosomal characterization and comparative cytogenetic analysis of two species of Proechimys (Echimyidae, Rodentia) from the Caatinga domain, Bahia, Brazil. Caryologia, 45: pp. 197212, 1992.

LEFEBVRE, L.; READER, S. M.; SOL, D. Brains, innovations and evolution in birds and primates. Brain Behavioral Evolution. 63: 233-246, 2004.

MANAF, P.; OLIVEIRA E. S. Behavioural repertoire of Proechimys [Trinomys] yonenagae (Rodentia: Echimyidae) in captivity. Revista de Etologia. 1 (2): pp. 3-15, 2000.

MARINO, L.; RILlinG, J. K.; LIN, S. K.; RIDGWAY, S. H.. Relative volume of the cerebellum in dolphins and comparison with anthropoid primates. Brain Behavioral. Evolution. 56: pp. 204-211, 2000.

NOWAK, R. M. Walker's Mammals of the World. 6 edition. London: The Johns Hopkins Univ. Press, 1999.

O'KEEFE, J.; NADEL, L .The hippocampus as a cognitive map. New York: Oxford University Press, 1978

PRAVOSUDOV, V.V.; CLAYTON, N.S. A test of the adaptive specialization hypothesis: population differences in caching, memory and the hippocampus in blackcapped chickadees (Poecile atricapilla). Behavioral Neuroscience, 116: pp. 515-522, 2002.

RATCLIFFE J. M. Neuroecology and diet selection in phyllostomid bats. Behavioral Processes. 80:247-251, 2009. 
RIBEIRO, M. F. S. Encéfalos de espécies de roedores Trinomys de diferentes habitats e seus correlatos ecotológicos. Dissertação de mestrado. Instituto de Psicologia. Universidade de São Paulo, 2004:

RILLING, J. K.; INSEL, T. R. Evolution of the cerebellum in primates: differences in relative volume among monkeys, apes and humans. Brain Behavioral. Evolution. 52: pp. 308-314. 1998.

ROCHA, P. L. B. Proechimys yonenagae, a new species of spiny rat (Rodentia: Echimyidae) from fossil sand dunes in the Brazilian Caatinga. Mammalia. 59: pp. 537-549, 1995.

ROCHA, P. L. B.; RENOUS, S.; ABOURACHID, A.; HOFLING, E. Evolution toward asymmetrical gaits in neotropical spiny rats (Rodentia: Echimyidae): evidences favoring adaptation. Canadian Journal of Zoology. 85: pp. 709-717, 2007.

ROWE, D. L.; HONEYCUTT, R. L. Phylogenetic relationships, ecological correlates, and molecular evolution within the Cavioidea (Mammalia, Rodentia). Molecular Biology and Evolution, 19: pp. 263-77, 2002.

SAFI, K.; DECHMANN, D. K. N. Adaptation of brain regions to habitat complexity: a comparative analysis in bats (Chiroptera). Proceedings of Royal. Society. B, 272: pp. 179-186, 2005.

SANTOS, J. W. A.; LACEY, E. A.. Burrow sharing in the desert-adapted torch-tail spiny rat, Trinomys yonenagae. Journal of Mammalogy, 92: pp. 3-11, 2011.

SCHOENEMANN, P. T.; SHEEHAN, M. J.; GLOTZER, L. D. Prefrontal white matter volume is disproportionately larger in humans than in other primates. Nat. Neuroscience. 8: pp. 242252. 2005.

SHERRY, D.F., Neuroecology. Annual Review of Psychology . 57: pp. 167-197, 2006.

SHERRY, D. F.; JACOBS, L. F.; GAULIN, S. J. C. Spatial memory and the adaptive specialization of the hippocampus. Trends in Neuroscience, 15: pp. 298-303, 1992. 
SHERRY, D.F.; VACCARINO, A.L. Hippocampus and memory for food caches in blackcapped chickadees. Behavioral Neuroscience. 103: pp. 308-318, 1989.

SHETTLEWORTH, S. J. Cognition, evolution, and behavior, 2nd ed. Oxford: Oxford University press, 2010.

SMULDERS, T. V.; GOULD, K. L.; LEAVER, L. A. Using ecology to guide the study of cognitive and neural mechanisms of different aspects of spatial memory in food-hoarding animals. Philosophy. Transctions. ofRoyal. Society. B. 365: pp. 883-900, 2010.

STREILEIN, K. E. The ecology of small mammals in the semiarid Caatinga. I. Climate and faunal composition. Annal. Carnegie Museum. 51: 79-107, 1982.

STRIEDTER, G. Principles of Brain Evolution. Sunderland, MA :Sinauer, 2005.

SZEKELY,T.; CATCHPOLE, C. K.; DEVOOGD, A.; MARCHL, Z.; DEVOOGD, T. J. Evolutionary changes in a song control area of the brain (HVC) are associated with evolutionary changes in song repertoire among European warblers (Sylviidae). Proceedings. of Royal. Society. B. 263: pp. 607-610, 1996.

ULLMANN, J. F. P.; COWIN, G.; COLLIN, S. P. Quantitative Assessment of Brain Volumes in Fish: Comparison of Methodologies. Brain, Behavior and Evolution. 76: pp. 261-270, 2010.

UPHAM, N. S., PATTERSON, B. D. Diversification and biogeography of the Neotropical caviomorph lineage Octodontoidea (Rodentia: Hystricognathi). Molecular Phylogenetics and Evolution. 63: pp. 417-429, 2012.

WHITING, B.; BARTON, R. A. Evolution of the corticocerebellar system in primates: anatomical projections predict patterns of correlated evolution. Journal. Human. Evolution. 44: pp. 3-10, 2003.

WILSON, M.A.; MCNAUGHTON, B.L., 1993. Dynamics of the hippocampal ensemble code for space. Science 261: 1055-1058.

WILSON, D. E.; REEDER, D. M. Mammal Species of the World: A Taxonomic and Geographic Reference, 3rd Edn. Baltimore, MD:Johns Hopkins University Press, 2005. 
EVOLUÇÃO DA ENCEFALIZAÇÃO NA ORDEM RODENTIA E SUAS DETERMINANTES ECOLÓGICAS, ETOLÓGICAS E DO DESENVOLVIMENTO. (CAPÍTULO 2) 


\section{RESUMO}

FREITAS, J. N. S. EVOLUÇÃO DA ENCEFALIZAÇÃO NA ORDEM RODENTIA E SUAS DETERMINANTES ECOLÓGICAS, ETOLÓGICAS E DO DESENVOLVIMENTO. 2013. Tese (Doutorado). Instituto de Psicologia - Neurociências e Comportamento - Universidade de São Paulo, São Paulo, 2013.

Mapeamos e reconstruimos a ancestralidade da encefalização em 382(Spp) de roedores, e a partir dos contrastes filogeneticos da encefalização testamos seis fatores relacionados a evolução da encefalização: Tipos de Habitat; uso espacial do habitat; dieta; atividade temporal; sociabilidade e estágio de desenvolvimento do neonato. A partir da massa do corpo (MC) e do encéfalo (ME) retirados da literatura (354spp) e estimados (28spp) em crânios depositados em coleções científicas. O quociente de encefalização $(\mathrm{QE})$ foi calculado a partir da regressão do logMExlog-MC e foi categorizado em três níveis, 0 (QE < esperado, QE $0-0,9) ; 1$ (esperado, QE 0.91 - 1,09) e o 2 (>esperado $\mathrm{QE} \geq 1,1$ ). Uma árvore foi gerada a partir de filogenias da literatura, sendo que as politomias foram resolvidas, utilizando-se filogenias recentes e específicas para os clados não-resolvidos. Através do Mesquite 2.73, mapeamos o estado ancestral do QE por parcimônia. O sinal filogenético pelo K e Lambda foram significantes. O mapeamento apresentou 122 passos evolutivos e inferiu $\mathrm{QE}<$ esperado para o ancestral de Rodentia. O QE > esperado foi um fenômeno que evoluiu independentemente 47 vezes em todos os grandes grupos de Rodentia. Todos os clados apresentaram o último ancestral comum (UAC) com QE<esperado. Em Sciuromorpha houve maior encefalização média que os outros clados. Sendo as famílias Sciuridae e Aplodontidae apresentaram UAC com QE>esperado. Em Hystricomorpha, O QE>esperado evoluiu inúmera vezes, principalmente nos Caviomorpha, destacando-se Erethizontidae, Caviidae, Hydrochaeridae, Dolichotidae, Dasyproctidae e Cuniculidae As familias com uso de habitat fossorial como Ctenomyidae e Octodontidae e as espécies arborícolas de Echimyidae apresentaram QE<esperado. Em Castorimorpha, Castoridae apresentou $\mathrm{QE}=$ esperado. Geomyidae que é subterrânea apresentou $\mathrm{QE}<$ esperado enquanto que o UAC de Heteromyidae apresentou QE>esperado cujo o clado evoluiu espécies com adaptações associadas ao deserto. Em Myomorpha, o QE>esperado surgiu mais vezes do que os outros clados. O UAC de Dipodoidea apresentou QE $>$ esperado e inclui tipo ecomorfologicos de deserto. Em Muroidea, Spalacidae que são subterrâneos apresentaram QE<esperado no UAC. 
Muridae se destaca por apresentar QE $>$ esperado, sendo que a subfamilia Gerbilinae de ratos-dedeserto apresentou QE>esperado no UAC. Quando testado o C-QE sobre os fatores determinantes da encefalização, $O$ tipo de habitat e o tipo de sociabilidade não influenciaram na encefalização de roedores, apesar destes fatores terem sido importantes para outros mamiferos ex: primates. $\mathrm{O}$ uso do habitat terrestre e semi-fossorial apresentam os maiores QE diferindo das semi-aquáticas e subterrâneas que apresentam os menores QE. Na dieta, as espécies omnívoras e de herbivoria rica apresentaram $\mathrm{QE}>$ de dieta herbívora pobre e generalista sugerindo que encefalização demanda dieta mais energética. $\mathrm{Na}$ atividade temporal, as espécies noturnas apresentaram encefalização $>$ as espécies diurnas e quetamerais. No estágio de desenvolvimento do neonato, as espécies altriciais apresentaram QE> precociais. Assim, a evolução do uso do habitat subterrâneo e fossorial dependeu da redução da encefalização como demonstrado nos testes de hipótese enquanto que o hábito semi-fossorial pode ter gerado mais demandas cognitivas para aumento, assim como a ocupação do habitat árido e semi-árido dependeu do aumento da encefalização em Rodentia. Palavras-chave: Encefalização, Rodentia, ancestralidade do carater, sociabilidade, desenvolvimento, evolução, caracteristicas ecomorfológica 


\section{ABSTRACT}

FREITAS, J. N. S. EVOLUTION OF THE ENCEPHALIZATION IN ORDER RODENTIA AND ITS ECOLOGICAL ETHOLOGICAL AND DEVELOPMENT DETERMINANTS. 2013. Thesis (Ph.D.). Instituto de Psicologia - Neurociências e Comportamento - Universidade de São Paulo, São Paulo, 2013.

We mapped and reconstructed the ancestry of encephalization in 382 species of rodents, and from phylogenetic contrasts of encephalization tested six factors related to the evolution of encephalization: Types of Habitat; spatial habitat use, diet, activity time, sociality and stage of development the neonate. From the mass of the body (MC) and the brain (ME) taken from the literature (354spp) and estimated (28spp) in skulls deposited in scientific collections. The encephalization quotient (EQ) was calculated from the regression of log-MExlog MC and was categorized into three levels, 0 (QE < expected or QE 0 to 0.9); 1 (expected QE or 0.91 - 1.09 ) and 2 ( $>$ expected or $\mathrm{QE} \geq 1.1)$. A phylogenetic tree was generated from the literature phylogeny, and the politomies were resolved using specific phylogenetic recent of the clades unsolved. Through Mesquite 2.73, we mapped the ancestral state of QE by parsimony. The phylogenetic signal by $\mathrm{K}$ and Lambda were significant. The mapping presented 122 evolutionary steps and inferred QE <expected for the ancestor of Rodentia. The QE> expected was a phenomenon that evolved independently 47 times in all major groups of Rodentia. All clades showed the last common ancestor (LCA) with QE < expected. In Sciuromorpha encephalization average was higher than the other clades. Being families Sciuridae and Aplodontidae LCA presented with $\mathrm{QE}>$ expected. In Hystricomorpha, The $\mathrm{QE}>$ expected evolved innumerable times, especially in Caviomorpha, highlighting Erethizontidae, Caviidae, Hydrochaeridae, Dolichotidae, Dasyproctidae and Cuniculidae The families Octodontidae and Ctenomyidae with habitat use as fossorial and arboreal species of Echimyidae presented QE <expected. In Castorimorpha, Castoridae presented $\mathrm{QE}=$ expected. Geomyidae that is underground dweller presented QE < expected while LCA Heteromyidae presented QE> expected, remarkable in clade whose species evolved adaptations associated with the desert life. In Myomorpha, QE $>$ expected evolved more often than the other clades. The LCA Dipodoidea presented QE> expected and includes ecomorphological type of desert. In Muroidea, which are subterraneans Spalacidae presented QE <expected LCA. Muridae excels due to QE> expected, and the subfamily Gerbilinae rat-de-desert presented $\mathrm{QE}>$ expected LCA. When tested the $\mathrm{C}-\mathrm{QE}$ on the 
determinants of encephalization, the habitat type and the type of sociality did not influence the encephalization of rodents, although these factors have been important in other mammals eg primates. The use of terrestrial habitat and semi-fossorial have the highest QE differing from semi-aquatic and subterranean at lowest QE. In the diet, omnivorous and rich herbivorous diet species showed QE> and generalist and poor herbivorous diet suggesting that encephalisation demand more energy. In temporal activity, the nocturnal species showed encephalisation> diurnal species and quetamerais. At the stage of development of the newborn, altricial species showed $\mathrm{QE}>$ precocial. Thus, the evolution of habitat use underground and fossorial depended on the reduction of encephalization as demonstrated in hypothesis tests while semi-fossorial habit may have generated more cognitive demands to increase, and the occupation of habitat arid and semi-arid depended encephalization increased in Rodentia. Keywords: Encephalization, Rodentia, ancestry of character, sociability, development, evolution, ecomorphological characteristics 


\section{INTRODUÇÃO}

A encefalização é um conceito comparativo que expressa a quantidade de tecido nervoso encefálico apresentado por uma espécie em relação a média de todas as espécies determinada por uma relação alométrica (JERISON 1973; HARVEY \& KREBS 1990; SHOENEMANN 2004; STRIEDTER 2005; LEFEBVRE ET AL 2007). A explicação da variação do padrão de encefalização entre as espécies ainda tem gerado um grande debate e interesse no campo da biologia evolutiva (HEALY \& ROWE 2007: BODDY ET AL 2012).

Desde do século XIX, a variação no tamanho dos encéfalos já havia chamado a atenção de Darwin, que afirmava que o tamanho relativo do encéfalo estaria relacionado com algo que ele denominou do "poder da cognição superiores" (STRIEDER 2007), mas até então não se havia uma coleção de dados suficientemente diversificada e métodos de análise comparada adequada para se testar esta hipótese e outras relacionadas a suas causas. Isso se daria só no século XX. Na tentativa de explicar a causa da variação do tamanho encefálico, Jerison (1973) propôs o seu princípio da massa própria (Proper mass) tendo como base a doutrina da localização das funções neuropsicológicas, e da relação entre as áreas de processamento sensorial e sua relação com o tamanho da superfície corporal onde se localizava os receptores sensoriais. Assim ele definiu que o tamanho do tecido neural controlador de uma função em particular é determinado pela quantidade de informação processada envolvida no desempenho da função. Mais recentemente sua hipótese foi complementada com outras duas hipóteses sobre os alvos da seleção para a variação do tamanho no encéfalo, na primeira, a seleção em um traço comportamental resultaria numa expansão coordenada de todo o cérebro (FINLAY \& DARLINGTON, 1995; ClANCY et al, 2001) e na segunda, que alterações de tamanho ocorressem apenas nas áreas especificamente relacionada à função relacionada com a característica de comportamento sob pressão seletiva 
(BARTON E HARVEY, 2000). Independente destas duas hipóteses, os neurobiólogos acreditam que o aumento no número de neurônios, e consequentemente, no tamanho do encéfalo resultaria no aumento na quantidade de armazenamento e velocidade no processamento de informação (JERISON 1973,1985; KRUBITZER \& KAAS 2005), logo aqueles indivíduos detentores destas capacidades na sua população poderiam aumentar sua chance de sobrevivência favorecendo a fixação de encéfalos cada vez mais aumentados (LEFEBVRE ET AL 2008).

Graças a acessibilidade aos dados encefálicos de um grande número de espécies de mamíferos atuais e inclusive fósseis, a mensuração do volume/massa do encéfalo pode ser feita cada vez mais, ampliando a abrangência das hipóteses em termos morfológicos, ecológicos e filogenéticos. Diversos trabalhos demonstraram cada vez mais a relação positiva entre do tamanho do encéfalo com o tamanho do corpo (MACE ET AL 1981; HARVEY \& KREBS, 1990; KRUSKA, 1987; TOWE \& MANN, 1992; Bush \& Allman, 2004), e reforçaram que esta interação dentre as duas variáveis em uma regressão não é mediada por uma relação isométrica, na qual a estrutura nervosa varia em função diretamente proporcional com o tamanho corporal, mas ao contrário, por uma relação alométrica,ou seja aquela em que o tamanho do encéfalo ou de suas partes varia de maneira desproporcional ao tamanho do corpo. Como o encéfalo tende a aumentar menos em relação ao corpo. A variação da regressão dada pelo intercepto com a abscissa é a base para o índice de encefalização utilizados atualmente nos estudos comparativos (STRIEDTER 2005). Além disso, essa variação nas linhas de tendência das regressões geraram resultados que ajudaram a demonstrar que alguns grupos taxonômicos, principalmente Aves e Mammalia, tenderam a uma encefalização maior que o esperado para o seus tamanhos, do que outros grupos mais basais de vertebrados (BUTLER \& HODOS 2005), sugerindo que estes sofreram 
maior pressão seletiva e/ou simplesmente mantiveram uma tendência de aumento da encefalização do grupo para a variação do tamanho do corpo.

Desta forma, o grau de encefalização foi um dos temas mais estudados no campo da neuroecologia nos últimos tempos (STRIEDTER 2005; SHETTLEWORTH 2010), principalmente quando se buscou o entendimento da evolução do sistema nervoso, partindo da premissa de que as variações no tamanho do encéfalo ou de suas partes seriam resultado de pressões seletivas relacionadas as demandas cognitivas geradas por fatores ecológicos e/ou por restrições fisiológicas das espécies (JERISON 1979; STRIEDTER 2005; SHERRY 2006).

No entanto, desde dos primeiros estudos comparativos (EISENBERG \& WILSON 1978; RADINSKI 1978; JERISON 1979; HARVEY ET AL 1980; MACE ET AL 1981, HOFMAN 1982; Gittleman 1986; Pirlot 1987; Shea 1987; Bauchot 1985; Whorthy \& Hickie 1986; Pagel \& Harvey 1989; PIRlot \& Nevo 1989) até início da década de 90 do século XX haviam limitações metodológicas quanto a análise dos dados, principalmente quanto a aplicação do teste de hipóteses utilizando a estatística convencional sobre os dados em que os pontos amostrais eram as espécies, de forma que a premissa de independência dos pontos amostrais era violada diante do relacionamento filogenético entre as espécies e portanto havia uma dependência entre as espécies, isto era denominado pseudoreplicação filogenética (READ \& NEE 1995) incorrendo em resultados falso-positivos. Assim a maioria dos estudos do passado explicitamente não levavam em consideração a filogenia no cálculo das linhas de regressão entre encéfalo e corpo. Até que Felsenstein (1985) estabeleceu que os pontos (espécies) em estudos comparativos não devem ser considerados independentes devido ao padrão de similaridade do traço avaliado está estruturado na filogenia devido à ancestralidade comum das espécies, a técnica responsável pela eliminação do efeito da filogenia ficou denominado de método dos contrastes independentes. 
A aplicação de métodos filogenéticos aos estudos comparados, além de resolver o problema da pseudoreplicação filogenética, ampliou poder de explicação das hipóteses de evolução, por meio do: (1) uso de filogenias (ou pelo menos de uma inferência de história), via mapeamento e reconstrução do estado ancestral do caráter e/ou do (2) uso de teste de hipóteses dos fatores causais (descontando o efeito da filogenia) que poderiam atuar na seleção do caractere seja na sua presença ou ausência e na variação de tamanho do carater (PAGEL 1992).

$\mathrm{Na}$ neurobiologia comparativa, podemos detectar padrões e testar os processos causadores destes padrões com a reconstrução do estado das características neuroanatômicas, comportamentais e ecológicas em um estoque ancestral e então fazer comparações com os conjuntos de características encontradas nos grupos descendentes existentes, uma vez identificada as diferenças, então poderemos formular hipóteses sobre os mecanismos de como as mudanças evolucionárias surgiram (BUTLER \& Hodos 2005). Assim podemos considerar que os métodos comparativos associados às filogenias permitem entender a história do caráter ao longo da filogenia. A sua utilização é uma ferramenta eficaz para determinar, se a encefalização é resultado do compartilhamento do caráter com o ancestral comum (forte sinal filogenético) ou se evoluiu independentemente em resposta a condições ecológicas similares (fraco sinal filogenetico) resultando em convergência adaptativa (HONEYCUTT et al 2007), Além do mais, a ocorrência de eventos de evolução independentes (convergência adaptativa) em clados distintos tem sido um modelo valioso para teste de hipóteses de evolução correlacionada e quanto maior a repetição dos eventos de homoplasia, mais robustas são as análises que testam hipóteses que associam a ecologia com o caractere (PAGEL 1999).

$\mathrm{Na}$ busca do entendimento dos processos, podemos categorizar os fatores que explicam a evolução da encefalização em ecológico, social e do desenvolvimento. Os fatores ecológicos e 
sociais são promotores, gerando demandas a encefalização e em alguns caso controladoresassim como o fator do desenvolvimento que é controlador, limitando a encefalização (JERISON, 1973; MACE ET AL 1981).

Ao longo dos estudos sobre encefalização, as primeiras hipóteses foram elaboradas a partir de fatores ecológicos, mais precisamente correlações entre tamanho do encéfalo e variáveis ecológicas, tais como as demandas geradas na busca de recursos (alimentares, abrigo e parceiro reprodutivos) e sua associação com o reconhecimento espacial da área de vida (PEREZ-BARBERIA ET AL 2007). Diversas pesquisas deram suporte às hipóteses ecológicas. Bauchot \& Stephan na década de 60 do século XX já demonstraram que em primates e insectivora, a complexidade do habitat, dieta especializada e a atividade noturna estavam relacionadas com aumento da encefalização (MACE ET 1981). Clutton-Brock \& Harvey (1980) observaram que as espécies de primatas folívoras apresentavam encéfalos relativamente menores do que os primatas insetívoros e as frugívoros, e ainda observaram uma relação com o forrageamento por frutos por impor alta demanda cognitiva, devido a tipo de distribuição espacial dos frutos na floresta. Por isso Martin (1984) propôs a hipótese da estratégia de forrageio para tratar da importância de encéfalos maiores na localização de alimentos energeticamente valiosos e de distribuição espacial e temporal imprevisível, pois esta demanda necessitaria de aumento no poder de armazenamento e processamento de informação. Além disso, as habilidades sensório-motoras requeridas na coleta e manipulação do alimento podem também promover a evolução de grandes encéfalos (PARKER \& GIBSON 1977; GIBSON 1986). Em Rodentia, para alguns grupos, as espécies habitantes de florestas apresentavam maiores encéfalos do que espécies de área aberta (BUDEAU \& VERTS 1986). 
A qualidade nutricional da dieta, também, tem sido um fator de controle sobre o tamanho do encéfalo. O tecido encefálico tem um custo de manutenção energética mais alto do que qualquer outro tecido (16\% da TMB, ASCHOFF et al 1971 apud AIELLO \& WhEELER 1995), mesmo durante o repouso ele se mantém neste patamar de consumo, ao contrário do sistema digestório e muscular que são mais transitórios quanto ao funcionamento. Assim qualquer aumento no tamanho do encéfalo implicaria no aumento da demanda por energia, que poderia ser suprida por consumo de alimentos mais ricos em energia, por isso uma dieta mais rica em energia poderia favorecer a evolução de encéfalos relativamente grandes. Esses achados corroboraram com a hipótese do tecido caro formulada por Aiello \& Wheeler (1995) que propuseram que o aumento de tamanho de um tecido caro deveria ser compensado pela redução de tamanho de outro tecido custoso, assim como o aumento do encéfalo algumas espécies apresentariam tamanho do sistema digestório relativamente menor que associada a um contexto de ingestão de alimentos de baixo custo de digestão, como carne e frutas, poderia sofrer tal redução. Além disso, outros achados sobre primatas (CLUTTON-BROCK \& HARVEY 1980), quirópteros (EISENBERG \& WilsON 1978) e roedores (MACE ET 1980; MANN et 1988) demonstraram que estas espécies com dieta especializada para itens energeticamente ricos (frutas, néctar e grão) tenderiam a apresentar encéfalos relativamente maiores que espécies de dieta mais energeticamente pobre (folhas e gramíneas) e baixa digestibilidade.

Além disso, a necessidade do conhecimento espacial sobre área domiciliar para satisfazer a demandas energéticas, rotas de fugas, localização do abrigo e predadores foi o fator apontado para estimular o aumento do tamanho do encéfalo (BUDEAU \& VERTS 1986; HARVEY \& KREBS 1990) Mais recentemente a hipótese da complexidade ambiental (GODFREY-SMith 1996) contribuiu no suporte ao papel da estruturação física do ambiente sobre a demanda por encéfalos 
aumentados (SHUMWAY 2008). Esta hipótese parte da premissa que uma das funções da cognição é capacitar o agente ao ajuste com a complexidade ambiental.

Em termos de processos evolutivos, o fator ecológico está mais próximo à caracterização do regime seletivo (tipos de habitat) que seleciona os estilos de vida (uso espacial do habitat), padrão de atividade temporal que, por conseguinte, promovem a evolução da encefalização.

O fator sociabilidade está associado às interações entre indivíduos, e surge a partir da agregação de indivíduos adultos, formando grupos sociais que tem continuidade espacial e temporal (PoOLE 1985), culminando no aumento da complexidade das interações entre indivíduos do grupo (DUNBAR 1998). Diversos estudos geraram dados de comportamento social em primatas (Dunbar 1998; Kummer et AL 1997; Whiten 2003 APUd MaCLeAn eT AL 2009; DunBar \& SHULTZ 2007) e demonstraram que espécies que vivem em grupos manejam uma ampla variedade de informações dinâmicas relevantes para a vida social, e que este processo é cognitivamente exigente de modo que um aumento na sociabilidade seja um dependente da evolução de cérebros grandes em relação ao tamanho do corpo (DUNBAR 1998). No entanto sabendo que hipótese do cérebro social foi proposta a partir de primatas, o fator social poderia promover a encefalização em outros grupos mais diversificados em termos específicos, ecológicos e sociais como Rodentia?

O último fator responsável por controlar o grau de encefalização está ligada ao desenvolvimento pré-natal que derivou a hipótese da energia maternal do Martin (1996) ela estabelece que a energia maternal seja um fator limitante à capacidade energética para o desenvolvimento do encéfalo fetal, sendo assim a taxa metabólica basal materna está relacionada com a taxa metabólica basal fetal, que por sua vez está relacionada com o tempo de gestação que controla em mamíferos o tamanho encefálico fetal, refletindo que em espécies altriciais (neonato pouco 
desenvolvimento) os neonatos apresentem encéfalos relativamente menores e quando adultos atinge encefalização superior em relação às espécies precociais (neonato muito desenvolvimento).

Em suma, a combinação de fatores promotores (Qualidade da dieta, localização de recursos complexidade ambiental, atividade temporal e interações sociais) com controladores (desenvolvimento e metabolismo) pode contribuir com a evolução da encefalização. Até aqui apesar da evidência sobre os fatores causais da evolução da encefalização serem bem documentadas, grande parte dos estudos foram realizados sem levar em consideração a relação filogenética entre as espécies, mas atualmente de posse dos métodos comparativos filogenéticos é possível avaliar o quanto a filogenia influencia os fatores descritos acima, por isso a necessidade de se reanalisar os dados estudados combinados com novos dados de grupos taxonômicos pouco estudados e contemplados nestes estudos comparativos.

Assim dentro de Mammalia, diversos estudos se notabilizaram por aplicar os métodos comparativos filogenéticos com a encefalização em diversos grupos de maneira isolada, baseando em dados da literatura e com base nas espécies mais estudadas como em Carnivora (Finarelli 2009), Artiodactyla e Primates (Perez-Barberia et 2007) Artiodactyla (PerezBarberia \& Gordon 2005), Cetacea (Marino 1998; Lefevbre et al 2006) Chiroptera (LAPOINTE eT Al 1999), Primates (MARINo 1998; DeANer 2007; BARRICKMAN 2008), mas como estes grupos taxonômicos são pouco diversificados em termos ecológicos e morfológicos (forma e tamanho corporal), isto limitou a quantidade das hipóteses causais que poderiam ser testadas simultaneamente sobre a evolução da encefalização.

$\mathrm{Na}$ tentativa de ampliar o escopo da diversidade de grupos de mamíferos avaliados num mesmo estudo, Boddy e colaboradores (2012) realizaram um estudo com 630 espécies de mamíferos de 
20 ordens, avaliando a ancestralidade da encefalização no grupo, mas sem testar hipoteses explicativas dos processos. Eles demonstraram que os maiores quocientes de encefalização estão presentes em clados como Proboscidae, Scandentia, Cetartiodactyla, Primates e Rodentia. Entretanto apenas a ordem Rodentia se apresenta mais apropriada para testes de múltiplos fatores num mesmo estudo. Pois ao contrário das outras ordens, Rodentia é a mais diversificada em termos específicos com mais de 2200 espécies (43\% da diversidade de mamíferos) (WILSON \& REEDER 2005), ecológicos (habitats, estilos de vida e tamanho corporal) e biogeográficos (NowAK 1999), além das razões biológicas, em termos metodológicos é um modelo de estudo acessível à coleta de dados, o que permite testar hipóteses de evolução da encefalização com um grande numero de espécies, mas para isso é necessário associar o grau de encefalização, com a história evolutiva de Rodentia e utilizando o método de reconstrução da ancestralidade do caráter, o que permitiria propor hipóteses adaptativas sobre a evolução da encefalização.

Apesar da grande diversidade de Rodentia, os estudos comparados de encefalização têm avaliado em sua maioria, espécies de clados de regiões paleártica e Neártica (MACE ET AL 1981), principalmente Sciuromorpha e Myomorpha, em detrimento dos clados de regiões neotropicais da América do sul, na qual aconteceram grandes eventos de irradiação adaptativa, como nos Sigmodontinae (Myomorpha) e nos Echimyidae (Hystricomorpha) (FABRE ET AL 2012).

Apesar de poucos, os estudos mais recentes com este grupo se limitam ao número de espécies analisadas, os estilos de vida e as hipóteses a serem testadas mesmo aplicando métodos comparativos filogenéticos (VASSALlo ET AL 2008; Sobrero ET AL 2011). Portanto a realização de um estudo mais amplo incluindo táxons como Echimyidae dos Caviomorpha se faz necessário, pois é o clado de Rodentia que sofreu uma grande irradiação evolutiva e adaptativa a partir do seu primeiro ancestral sul-americano, ocasionando a maior diversificação do que 
qualquer outro grupo similar de Mammalia (HERSHKOVITZ 1972), ocupando todos os habitats disponíveis do temperado frio a floresta quente e úmida, variando de formas de hábito semiaquáticas, arborícolas e fossoriais e alcançando uma ampla variação de tamanho de ratos-deespinho (Gênero Trinomys) de $0.15 \mathrm{~kg}$ a capivaras (Hydrochaerus hydrochaeris) 70kg. Além da diversidade de hábitos alimentares de herbívoros, frugívoros, folívoros e granívoros (MARES \& OJEDA 1982) Assim a inclusão de mais espécies de Caviomorpha é essencial aos trabalhos comparativos mais robustos sobre encefalização.

Em vista deste histórico, qual seriam os fatores causais para evolução da encefalização em Rodentia, explorando mais espécies em todos os clados do grupo e avaliando-se dentro de um perspectiva dos metodos comparativos filogenéticos? Já que o grupo é um clado com monofiletismo apoiado em dados morfológicos (LUCKETT \& HARTENBERGER 1993; HUCHON ET AL 2002; 2007; BlANGA-KANFI ET AL 2009; FABRE ET AL 2012), que apresentam uma grande diversificação ecológica (habitat e estilos de vida), social (diversos tipos de sociabilidade, inclusive eussociabilidade) de estratégia reprodutiva (altricial e precocial) e de atividade (noturno, quetameral e diurno) (EISENBERG 1981; NOWAK 1999). Em vista disso podemos testar as principais hipóteses (Cérebro social (DunBar 1998), tecido caro (AIELlo \& WHEELER 1995), energia maternal (Martin 1996), complexidade ambiental (BUDEAU \& VERTS 1986; SHUMWAY 2008), que explicam a variação na encefalização em outros mamíferos mais estudados, como Primates, Artiodactyla e Carnivora. 


\section{OBJETIVO}

O objetivo do nosso trabalho é avaliar a evolução da encefalização na ordem Rodentia, (1) mapeando e reconstruindo a ancestralidade do carater encefalização na filogenia de 382 espécies de roedores dos cinco grande clados do grupo e por fim, testar hipóteses evolutivas de encefalização com base nos fatores causais ao fenômeno, como o tipo de habitat (habitat aberto, misto e florestado), o uso espacial do habitat (Terrestre, semi-fossorial, fossorial, subterrâneo, semi-aquático, arborícola) uso temporal do habitat (noturno, quetameral e diurno), tipo de sociabilidade (solitário, semi-social e social), grau de desenvolvimento do neonato (altricial e precoce) e tipo de dieta (animal, omnívora, herbivora generalista, herbivora pobre e herbivora rica em energia).

Se as hipóteses se confirmarem então será esperado:

(1) Com relação ao regime seletivo, que as espécies de área florestada apresentem encefalização acima do esperado em relação as espécies de área aberta;

(2) Com relação ao uso espacial do habitat é esperado que as espécies que utilizem ambientes espacialmente complexos (ex: arborícola) apresentem maior encefalização do que aquelas que utilizem mais simples (ex: terrestre);

(3) Com relação a dieta esperasse que as espécies que consumam alimentos mais ricos em energia (ex: dieta animal, grãos e frutas) apresentem encéfalos aumentados;

(4) Com relação a atividade temporal esperasse que as espécies de hábito noturno apresentem encéfalo aumentado em relação as espécies de hábito diurno;

(5) Com relação a sociabilidade esperasse que as espécies sociais apresentem encéfalos relativamente maiores que as espécies solitárias; 
(6) Com relação ao estado de desenvolvimento do neonato esperasse que as espécies que apresentem neonatos altriciais apresentem encéfalos adultos de tamanho relativamente maior que as espécies precociais. 


\section{MATERIAL E MÉTODOS}

Este trabalho avaliou dados de 382 espécies de roedores dos cinco clados de Rodentia (WILSON \& READER 2005): Myomorpha (167spp), Castorimorpha (34spp), Anomalurimorpha (1spp), Hystricomorpha (104spp) e Sciuromorpha (76spp).

\section{Variável mensurada}

Os dados de massa do encéfalo (ME) e massa do corpo (MC) foram obtidos a partir de dados secundários da literatura (354spp) (HRDLICKA 1905; VON BONIN 1937; CRILE \& QUIRING 1940; Pilleri 1962; COMPOINT-Monmignaut 1973, SACHER \& STAFFELdT 1974; MACE ET AL 1981; Hofman 1982; Roth \& ThORINGTON 1982; MACE \& EISENBERG 1982; HAFNER \& HAFNER 1984; Fox \& Wilczynski 1986; Pirlot \& BeE De Speroni 1987; ManN ET AL 1988; MCNAB \& EISENBERG 1989; Towe \& MANN 1988; BernARD \& NuRTON 1993; HofMAN 1993; JACOBS \& SPENCER 1994; Glendening \& MASTERTON 1998; MonAdJen 1998; RIBEIRO 2004; VASSALlo \& ECHEVERRIA 2008; KRUSKA \& STEFFEN 2009; BODDY ET AL 2012) e primários estimados (28spp da família Echimyidae, Hystricomorpha) do preenchimento com pólvora (grão de 2mm) do volume dos crânios depositados em coleções científicas do Museu de zoologia da USP e Museu Nacional/UFRJ. A massa de polvora foi convertida na massa do encéfalo fresco a partir de um fator de transformação obtido de teste de medida da massa fresca do encéfalo de animais congelados avaliados pelo método do deslocamento de massa da água do princípio de Arquimedes, no qual cada grama de pólvora equivaleria $0.84 \mathrm{~g}$ de massa fresca do encéfalo (Fig. 1). 

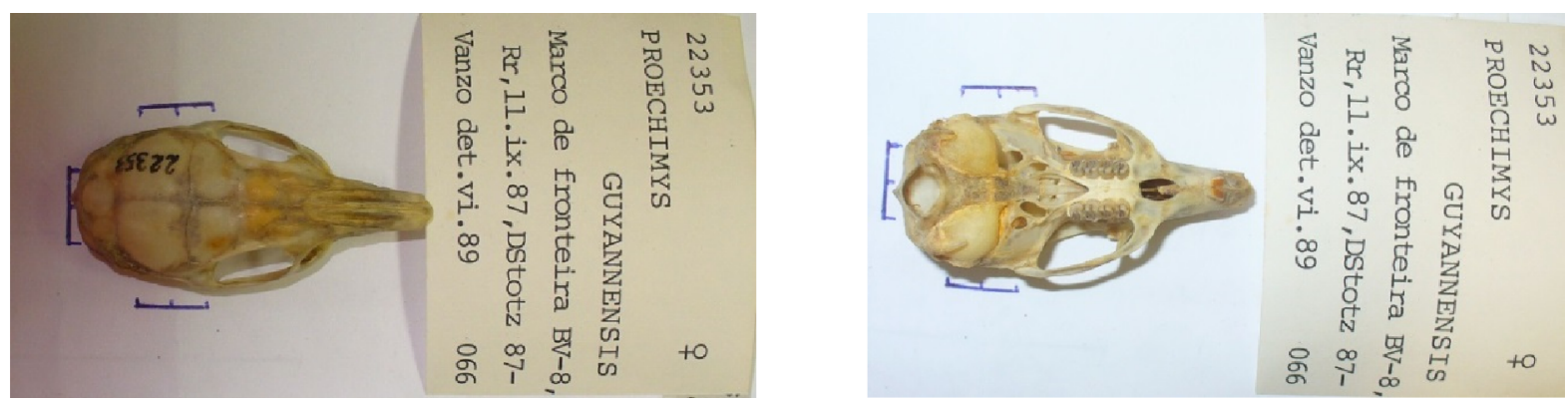

Figura 1. Crânio de rato-de-espinho (Proechimys guyannensis) da coleção do Museu de Zoologia da USP (escala de $1 \mathrm{~cm}$ marcada na lateral do crânio), utilizado na aferição do volume da caixa craniana pelo preenchimento com pólvora.

O quociente de encefalização (QE) é a razão da ME observada pela ME esperada, na qual a ME esperada é derivada da MC das espécies medidas neste estudo para as 382 espécies de Rodentia. $\mathrm{O} \mathrm{QE}$ foi calculado pela equação $\mathrm{ME} / \mathrm{k}^{*} \mathrm{MC}^{\alpha}$, onde $\mathrm{k}$ é o intercepto no eixo y e $\alpha$ é o expoente alométrico. Os valores de $\mathrm{k}$ e $\alpha$ foram obtidos a partir da linha de regressão da plotagem dos pontos do $\log \mathrm{ME}$ pelo $\log \mathrm{MC}$. O expoente alométrico foi de 0,5836 e o intercepto com eixo y foi de -0.9071 . Baseado na fórmula alométrica $\mathrm{E}=\mathrm{kP}^{\alpha}$, e depois na log-transformação do $\mathrm{y}$ (ver Jerison, 1973), chegamos a fórmula $\mathrm{QE}=\mathrm{ME} / 0.1238^{*} \mathrm{MC}^{0,5836}$. A interpretação do $\mathrm{QE}$ pode ser dada a partir da sua relação com a linha de regressão plotada a partir do gráfico Log ME pelo Log MC. Se o QE esta sobre a linha de regressão, ele é igual a 1, e a ME é esperada para o tamanho do corpo daquela espécie, sendo o $\mathrm{QE}<1$, ele indica que a ME é menor do que o esperado para aquele tamanho de corpo e quando o $\mathrm{QE}>1$, ele indica que é maior que esperado. Seguindo a interpretação acima mencionada, o valor contínuo do QE foi categorizado para fins de análise filogenética em três níveis $(0,1$ e 2), de acordo com os seguintes critérios, sendo o nível 0 (QE menor que o esperado) com o QE variando de 0 - 0,9; nível 1 (esperado) com QE variando de 0.91 - 1,09 e o nível 2 (maior que o esperado) com o QE $\geq 1,1$. 


\section{Mapeamento e reconstrução da ancestralidade}

O mapeamento e a reconstrução do estado ancestral do caráter da encefalização foi feito no programa Mesquite 2.73, no qual foi aplicado o método da parcimônia. O sinal filogenético (Blomberg et al, 2003) foi estimado pelo cálculo do K de Blomberg (2003) e Lambda ( $\lambda$ ) de Pagel (1999) por meio do pacote Picante no programa R 2.15.1.

O sinal filogenético é uma mensuração do grau do quanto uma filogenia é capaz de predizer a similaridade entre espécies. A estatística do $\mathrm{K}$ de Blomberg é uma medida do sinal filogenético observado quando comparado ao sinal de um caráter sob um modelo de evolução de movimento browniano em uma filogenia. Os Valores do $\mathrm{K}$ variam de zero ao infinito, mas os maiores valores tendem a ficar entre um e dois. $\mathrm{O}$ valor de $\mathrm{K}=1$ corresponde a um processo evolução por movimento Browniano, que implica em algum grau de sinal filogenético ou conservadorismo filogenético. Os valores do $\mathrm{K}$ mais próximos de zero correspondem a um padrão aleatório ou padrão convergente de evolução, enquanto que os valores de $\mathrm{K}$ maiores do que um indicam sinal filogenético mais forte e conservadorismo dos caracteres.

A significância estatística do sinal filogenético pode ser avaliada comparando os padrões observados da variância dos contrastes independentes do traço de um modelo nulo de aleatorização táxons terminais através das pontas da filogenia. O lambda $(\lambda)$ de Pagel é outro estimador do sinal filogenético que é baseado em um parâmetro de escala de comprimento de ramos de uma filogenia que varia de 0 a 1 , assim quando o $\lambda$ vai de um a zero, os ramos internos se tornam menores e a filogenia se torna mais formato de estrela, como se todos os ramos partissem de um único nó e isto representa baixo sinal filogenético. 
A análise foi aplicada sobre a filogenia das 382 espécies de roedores extraída da filogenia de Bininda-Emonds e colaboradores (2007) para a classe Mammalia e ajustada as propostas mais recentes para ordem Rodentia (Veniaminova et al 2007; Montegelard Et 2008; BangaKANFI ET AL 2009; ChURAKOV ET AL 2010). já as politomias foram resolvidas baseando-se prioritariamente nas hipóteses filogenéticas mais recentes, a partir de dados moleculares e secundariamente em dados morfológicos. Assim como os taxóns ausentes que foram incorporados e posicionados na topologia a partir de filogenias dos clados e sub-clados das famílias de Rodentia: Dipodidae (FAn et Al 2009; Zhang ET AL 2013), Muridae (JANSA \& WeKsler 2004; Steppan et al 2004), Murinae (StepPan et Al 2005; GefFen et al 2011), Gerbilinae (Ito et al 2010) Arvicolinae (Robovsky et al 2009; GALEWSKI et al 2006) Peromyscinae (Miller \& Engstrom 2008), Sigmodontinae (D’Elia 2003; PARADA ET AL 2013), Anomalurimorpha (Blanga-Kanfi et AL 2009) Castoridae (Montgelard ET AL 2008), Geomyidae (HAFNER ET AL 2009), Heteromyidae (AlEXANDER \& RidDle 2005), Octodontoidea (UPHAM \& PATterson 2012) Echimyidae (FABre et 2013), Aplodontidae (Hopkins 2008),

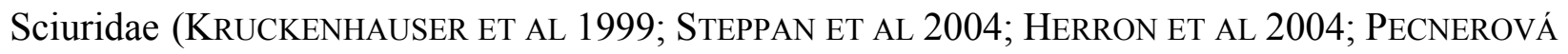
\& MARTINKOVÁ 2011; ReID ET AL 2012) e Gliridae (NunOME ET AL 2007).

Visando testar a diferença do quociente de encefalização entre os cinco clados (Myomorpha, Anomalurimorpha, Castorimorpha, Hystricomorpha e Sciuromorpha) de Rodentia, aplicamos uma ANOVA de um fator com assumindo $\mathrm{p}<0.008$ seguido de teste de comparação múltipla de Tukey.

Os contrastes filogenéticos foram calculados no PDAP do Mesquite 2.73 a partir dos dados do quociente de encefalização para todas as espécies da árvore filogenética com aplicação do comprimento de ramo pelo método de Pagel (1992). 
Como sugerido por Garland et al. (1992), os valores absolutos dos contrastes foram plotados contra seus desvios-padrão do Log da massa do encéfalo e Log da massa do corpo e não foi encontrada correlação significativa $\left(\operatorname{LogME}: \mathrm{r}^{2}=0.004, \mathrm{P}=0.199 ; \log \mathrm{MC}=\mathrm{r}^{2}=0.006, \mathrm{P}=\right.$ 0.128), sugerindo que a transformação do comprimento ramo foi apropriada.

Visando extrair o efeito do sinal filogenéticos dos dados brutos, foi calculado os contrastes do QE (C-QE) a partir dos contrastes independentes obtidos dos dados brutos do Log-ME e LogMC, da filogenia das espécies e dos comprimentos de ramo, está tecnica permitiu obter o valor por espécies ao invés do valor por nô de cada ponto de cladogênese, que é o que cada valor do contraste representa. Assim plotamos o contraste do log ME pelo contraste do log MC, extraimos e linha de regressão dos pontos e a equação da reta. O expoente alométrico foi de 1.36 e o intercepto com eixo y foi de -0.00086 . Baseado na fórmula alométrica $\mathrm{E}=\mathrm{kP}^{\alpha}$, e depois na logtransformação do y (ver Jerison, 1973), chegamos a fórmula do $\mathrm{QE}=\mathrm{ME} / 0.998 * \mathrm{MC}^{1,36}$ ).

$\mathrm{O} \mathrm{QE}$ dos dados brutos e o C-QE foram aplicados nos testes de hipótese ecológicos, etologicos e do desenvolvimento de forma a avaliar o efeito da presença e ausência do sinal filogenético sobre a variação do $\mathrm{QE}$ diante dos fatores.

\section{Classificação das espécies quantos aos fatores ecologicos, sociais e do desenvolvimento}

Para fins de teste de hipótese dos fatores levantados neste trabalho todas as espécies foram classificadas quanto a seis fatores: (1) Habitat; (2) Uso espacial do habitat; (3) Tipo de dieta; (4) Atividade temporal; (5) Sociabilidade e (6) Estagio de desenvolvimento do Neonato.

(1) O fator habitat foi considerado como um dos componentes do regime seletivo, que está relacionado pelo papel do ambiente (combinação do meio fisico e biológico) (Baum \& Larson 1991) na seleção da encefalização. Como meio de classificação, nos 
consideramos o tipo de cobertura vegetal como variável discreta representativa da complexidade do habitat. Nos definimos três níveis deste fator: $0=$ Florestado (máxima cobertura vegetal); 1 = Misto (para espécies que usam ambos ambientes) e 2 = Aberto (Mínima cobertura vegetal).

(2) O fator uso espacial do habitat é considerado aqui o mesmo que estilo de vida para outros autores e é uma combinação do tipo de substrato, locomoção, abrigo e complexidade do habitat. Nos definimos seis níveis deste fator: $0=$ terrestre; $1=$ semi-fossorial (terrestre que escava e vive em túneis subterrâneos e não apresentam morfologia relacionada à escavação); 2 = fossorial (escava e vive em túneis subterrâneos, apresentam alguma morfologia relacionada à escavação, mas ainda buscam alimento na superficie); 3 = subterrâneo (morfologia relacionada a escavação, vida completamente epígea); 4 = semi-aquática (vive principalmente em corpos d'água durante algum momento de suas atividades inclusive para alimentação ou não); 5 = arborícola (habita e escala árvores);

(3) O fator tipo de dieta está relacionada a origem do alimento (animal ou vegetal) e o seu teor nutricional energético. Nos definimos cinco níveis deste fator: $0=$ animal (carnívora/insetívora); 1 = omnívora (generalista, variando entre tipo animal ou vegetal); 2 = herbívora pobre (rica em celulose); 3 = herbívora rica (frutos, grãos e tubérculos); 4 = herbívora generalista (todas as partes da planta);

(4) O fator atividade temporal está relacionado ao período do dia em que o animal está mais ativo. Nos definimos três níveis deste fator: $0=$ noturno; $1=$ quetameral (amanhecer e/ou crepuscular) e 2 = diurno; 
(5) $\mathrm{O}$ fator sociabilidade foi definido de acordo com a continuidade temporal e espacial da interação social entre animais adultos de igual ou diferentes sexos (PoOLE 1985). Nos definimos três níveis deste fator: 0 = solitário (territorial ou não); 1 = semi-social (formação sazonal de grupos e formação de pares reprodutivos) e 2 = social (grupos multi-macho, multi-fêmeas, colônias e eussociais);

(6) O fator estágio de desenvolvimento do neonato. Nos definimos dois níveis deste fator: $0=$ altricial (neonato apresenta estado subdesenvolvido ao nascer com olhos fechados e sem pêlos, totalmente dependente da mãe) e $1=$ precocial (neonato apresenta estado desenvolvido ao nascer com pelos e de olhos aberto). 


\section{Análise dos fatores ecológicos, sociais e do desenvolvimento}

Visando enquadrar os dados nas premissas da analise de variância (ANOVA), os dados foram testados quanto a normalidade e homocedasticidade. $\mathrm{O}$ não-enquadramento nas premissas dos testes resultou em transformação (normalidade) e aplicação de ANOVA que assumisse a heterocedasticidade dos dados como os testes de Welch e Brown-Forsythe (Quinn \& Keough 2002).

Devido a repetibilidade dos dados em mais de um teste favorecer erro do tipo I, o p dos testes foram corrigidos por meio da correção de Bonferroni, na o p proposto (0.05) é dividido pelo número de testes aplicados (seis). Assim assumimos o $\mathrm{p}<0.008$ para rejeitar a hipótese nula.

\section{Habitat}

O primeiro fator proposto por este trabalho foi testado a partir da hipótese de que há diferença na encefalização das espécies de roedores entre os três niveis do fator regime seletivo (Florestado, misto e aberto)?

\section{Uso do habitat}

O segundo fator proposto por este trabalho foi testado a partir da hipótese de que há diferença na encefalização das espécies de roedores entre os seis níveis do fator uso do habitat (terrestre, semi-fossorial, fossorial, subterrâneo, semi-aquático e arborícola)? 


\section{Tipo de dieta}

O terceiro fator proposto por este trabalho foi testado a partir da hipótese de que há diferença na encefalização das espécies de roedores entre os cincos níveis do fator tipo de dieta (animal, omnívora, herbívora generalista, herbívora rica e herbívora pobre)?

\section{Atividade temporal}

O quarto fator proposto por este trabalho foi testado a partir da hipótese de que há diferença na encefalização das espécies de roedores entre os três níveis do fator atividade temporal (noturna, quetameral e diurna)?

\section{Sociabilidade}

O quinto fator proposto por este trabalho foi testado a partir da hipótese de que há diferença na encefalização das espécies de roedores entre os três níveis do fator sociabilidade (solitário, semisocial e social)?

\section{Estágio de desenvolvimento do neonato}

O sexto fator proposto por este trabalho foi testado a partir da hipótese de que há diferença na encefalização das espécies de roedores entre os dois níveis do fator estágio de desenvolvimento do neonato (altricial e precocial)?

Todos os fatores foram testados em uma análise de variância (ANOVA) de um fator suscedidas por testes ad hoc de comparação multipla entre os niveis dos fatores assumindo o mesmo $\mathrm{p}$ $<0.008$. Os testes foram realizados no programa SPSS 17.0. for Windows. 


\section{RESULTADOS}

Os dados de massa do encéfalo (ME) e massa do corpo (MC) das 382 espécies foram plotados num gráfico de dispersão dos pontos (Fig. 2) e a partir da relação log $\mathrm{ME}$ e $\log \mathrm{MC}$ no qual foi gerada a equação da linha de regressão $=y=0.5836 x-0.9071$ no qual ficou demonstrando que relação alométrica foi significativamente negativa $(F=2587$; slopo de $0.584 ; \mathrm{p}<0.0001)$.

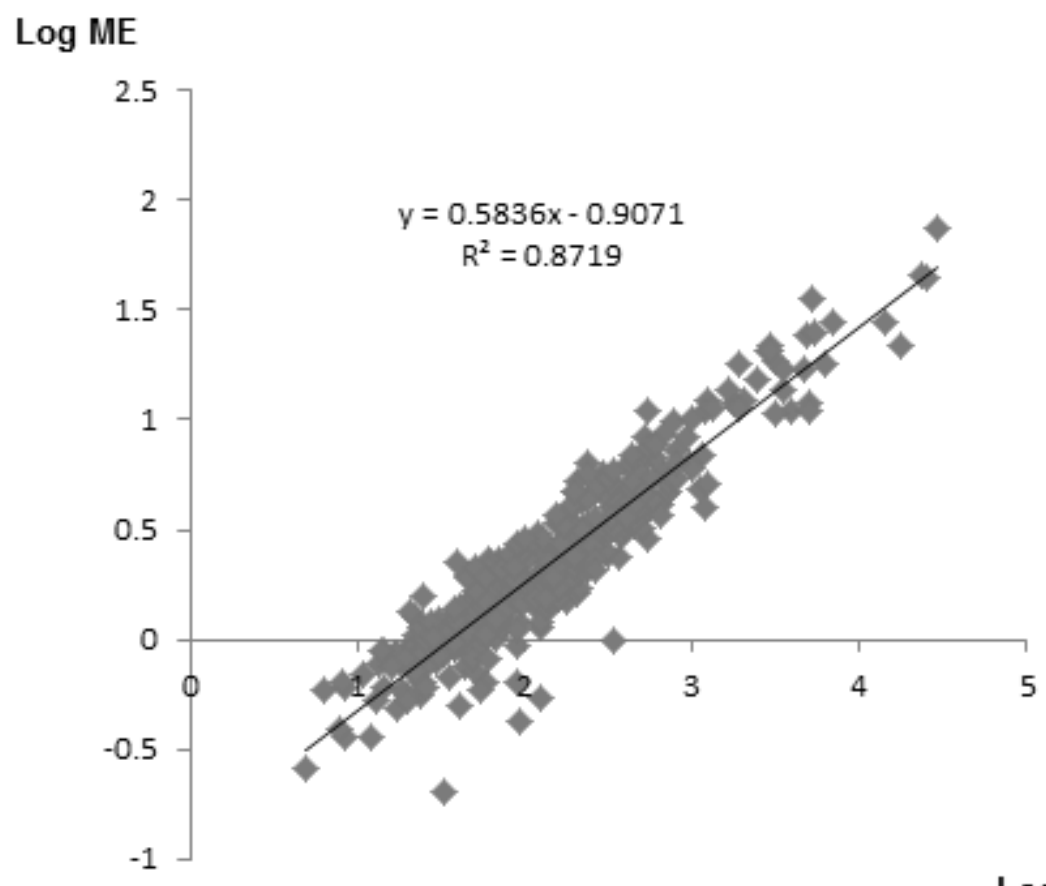

$\log M C$

Figura 2. Relação entre Log da massa do encéfalo pelo Log da massa do corpo para 382 espécies da ordem Rodentia com linha de regressão, equação da linha e coeficiente de determinação.

Os contrastes filogenéticos obtido do log da massa do encéfalo pelo log da massa do corpo foram plotados em gráfico (Fig. 3) o que gerou linha de regressão $=y=1.3603 x-0.0009$ no qual ficou demonstrando que relação alométrica foi significativamente negativa $(\mathrm{F}=390.52$; slopo de 1.36 ; $\mathrm{p}<0.0001)$. 


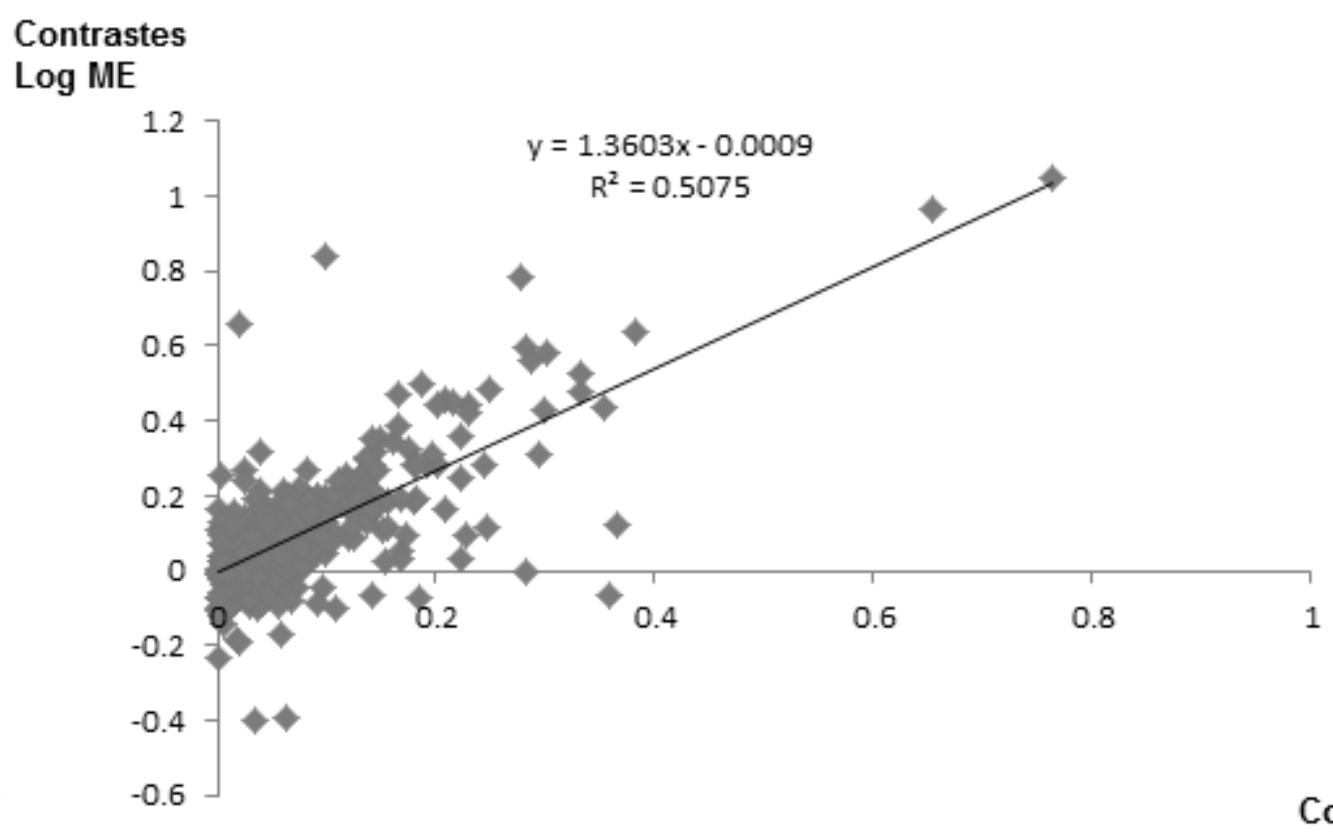

\section{Contrastes}

$\log$ MC

Figura 3. Relação entre contraste do Log da massa do encéfalo pelo contraste do Log da massa do corpo para 382 espécies da ordem Rodentia com linha de regressão, equação da linha e coeficiente de determinação.

\section{Mapeamento e reconstrução do estado ancestral}

A variação da encefalização entre as espécies apresenta suporte na filogenia, pois as estimativas de sinal filogenético representadas pelo $\mathrm{K}=0.2216 ; \mathrm{p}=0.000999$ e $\lambda=0.6618 ; \mathrm{p}<0.0000$ tanto para $\lambda=1$ quanto para $\lambda=0$ foram significativos.

O mapeamento por parcimônia do QE discretizado envolveu 122 passos evolutivos e inferiu o QE nível 0 (entre 0,0 e 0.9 de QE, abaixo do esperado para o tamanho do corpo) para o último ancestral comum de Rodentia. O QE nível 2 (>1.10 acima do esperado para o tamanho do corpo) foi um fenômeno que evoluiu independentemente 47 vezes em todos os cinco clados de Rodentia. As reversões para os niveis 1 e 0 aconteceram 35 vezes (Fig. 4).

Do clado Sciuromorpha (Esquilo, marmota, cão-da-pradaria, castor-da-montanha e arganaz) (figura 5) foram avaliadas 76 espécies e foi inferido o nível de $\mathrm{QE}=0$ para condição do último ancestral comum (UAC). A condição nível de $\mathrm{QE}=2$ evoluiu seis vezes com cinco eventos de 
reversão, sendo que a família Sciuridae apresentou o nível de $\mathrm{QE}=2$ a partir do último ancestral comum, além de apresentar mais eventos homoplásicos.
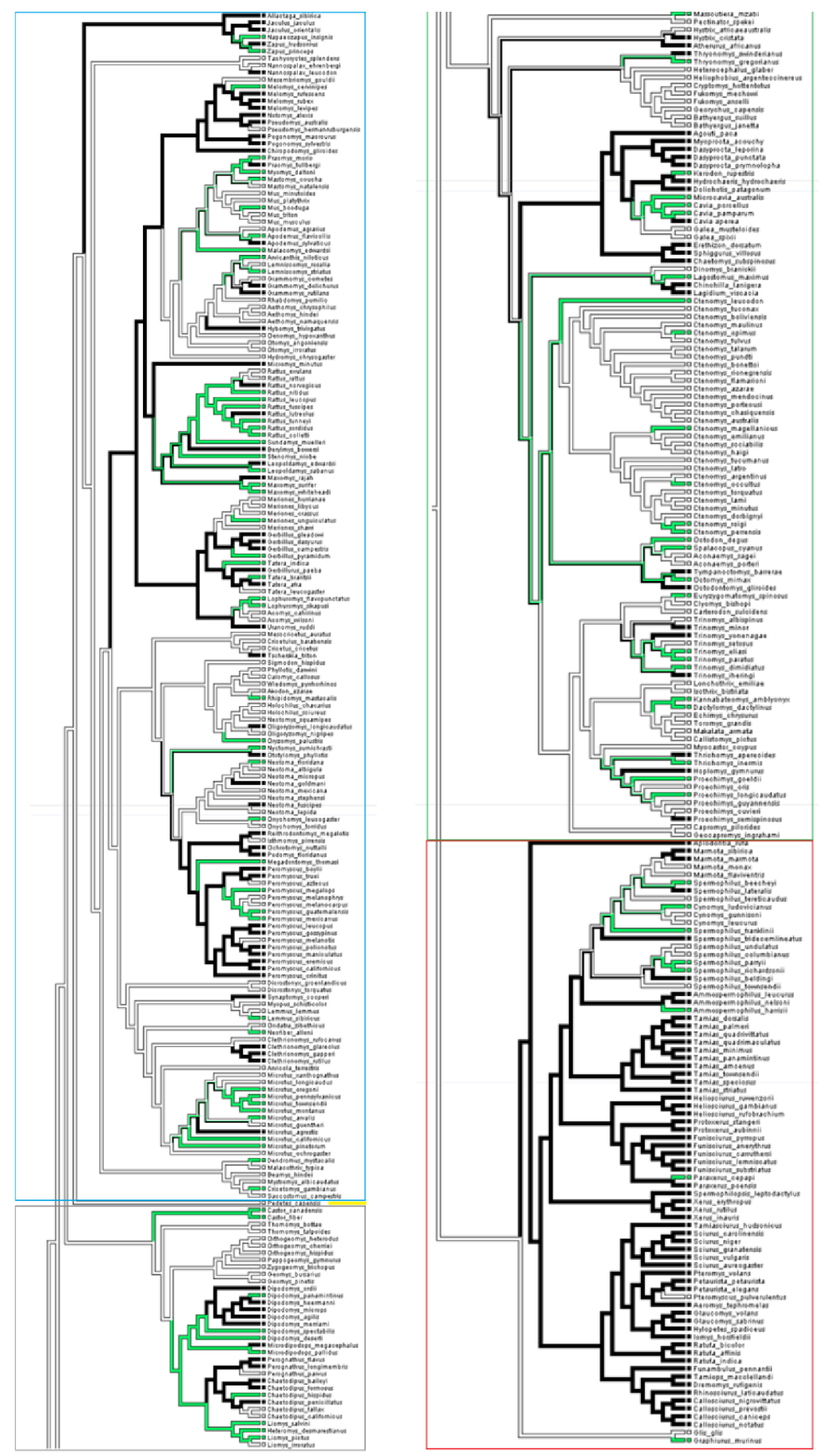

Figura 4. Filogenia das 382 espécies da ordem Rodentia com o mapeamento do estado da encefalização baseada do quociente de encefalização (QE) discretizado em três níveis 0 cor branca (QE 0-0.90); 1 cor verde (QE 0.91-1.10) e 2 cor preta $(>1.10)$ pelo método da parcimônia. Em destaque, as cinco subordens de Rodentia: Myomorpha (azul), anomalurimorpha (amarelo), castorimorpha (cinza), Hystricomporpha (verde) e Sciuromorpha (vermelho). 
Dentre os sub-clados, a tribo Marmotini, representada pelos gêneros Tamias, Ammospermophilus, Spermophilus, Cynomys e Marmota apresentou eventos de reversão em todos os gêneros, sendo o mais destacado no gênero Spermophilus. A família monogenêrica Aplodontidae (castor-da-montanha) apresentou nivel de $\mathrm{QE}=2$ a partir do ultimo ancestral comum. E por fim a familia Gliridae (arganaz) apresentou nivel de QE $=0$ para o ultimo ancestral comum.

O clado Hystricomorpha (porco-espinho, capivara, porquinho-da-índia, rato-de-espinho) (Fig. 6) foi avaliado em 104 espécies e foi inferido o nível 0 para condição do último ancestral comum. A condição nível 2 evoluiu 13 vezes com sete eventos de reversão, sendo que o clado que reúne as famílias Erethizontidae, Caviidae, Hydrochaeridae, Dolichotidae, Dasyproctidae e Cuniculidae apresentou o nivel 2 a partir do ultimo ancestral comum. Os outros eventos de encefalização nível 2 surgiram de maneira pontual em espécies da familia Chinchillidae, Octodontidae e Echimyidae, enquanto que a familia Capromyidae apresentou reversão ao estado ancestral (nível $0)$.

O clado Castorimorpha (castor, rato-canguru e rato-touperia) (Fig. 7) foi avaliado em 34 espécies e foi inferido o nível 0 para condição do último ancestral comum. A condição nivel 2 evoluiu três vezes com cinco eventos de reversão. Sendo que na família Castoridae apresenta evento de encefalização nivel 1. A familia Geomyidae mantém o nivel 0 para seu ultimo ancestral comum, enquanto que em Heteromyidae surgem os eventos de encefalização nível 2.

O clado Anomalurimorpha (lebre-saltadora) (Fig. 9) foi avaliado a partir da espécie Pedetes capensis em que foi inferido o nível 0 desde o ancestral comum com Myomorpha.

O clado Myomorpha (rato, camundongo, leminges, hamster, voles) (Fig 8 e 9) foi o que apresentou mais espécies avaliadas da ordem Rodentia com 167 ao todo, e foi inferido o nível 0 
para condição do último ancestral comum. A condição nivel 2 evoluiu 25 vezes com 18 eventos de reversão. No nível dos sub-clados, a partir do último ancestral comum (UAC) da superfamília Dipodoidea surge o primeiro evento da condição QE nível 2 (acima do esperado).

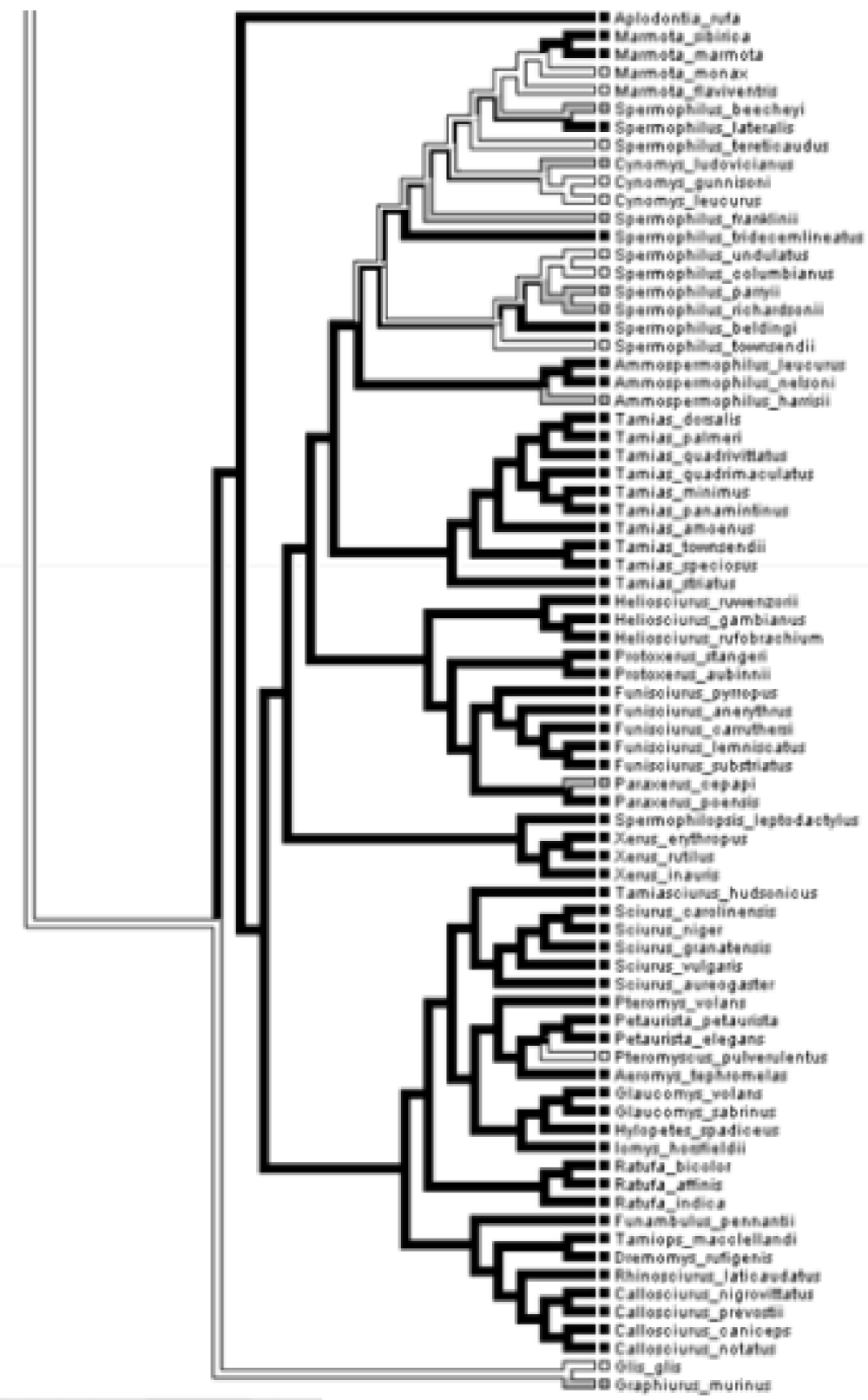

Figura 5. Filogenia das 76 espécies de Sciuromorpha a partir da filogenia do trabalho com o mapeamento pelo método da parcimônia do estado da encefalização baseada no quociente de encefalização (QE) discretizado em três níveis 0 cor branca (QE 0-0.90); 1 cor cinza $(0.91-1.10)$ e 2 cor preta $(>1.10)$ pelo método da parcimônia. 


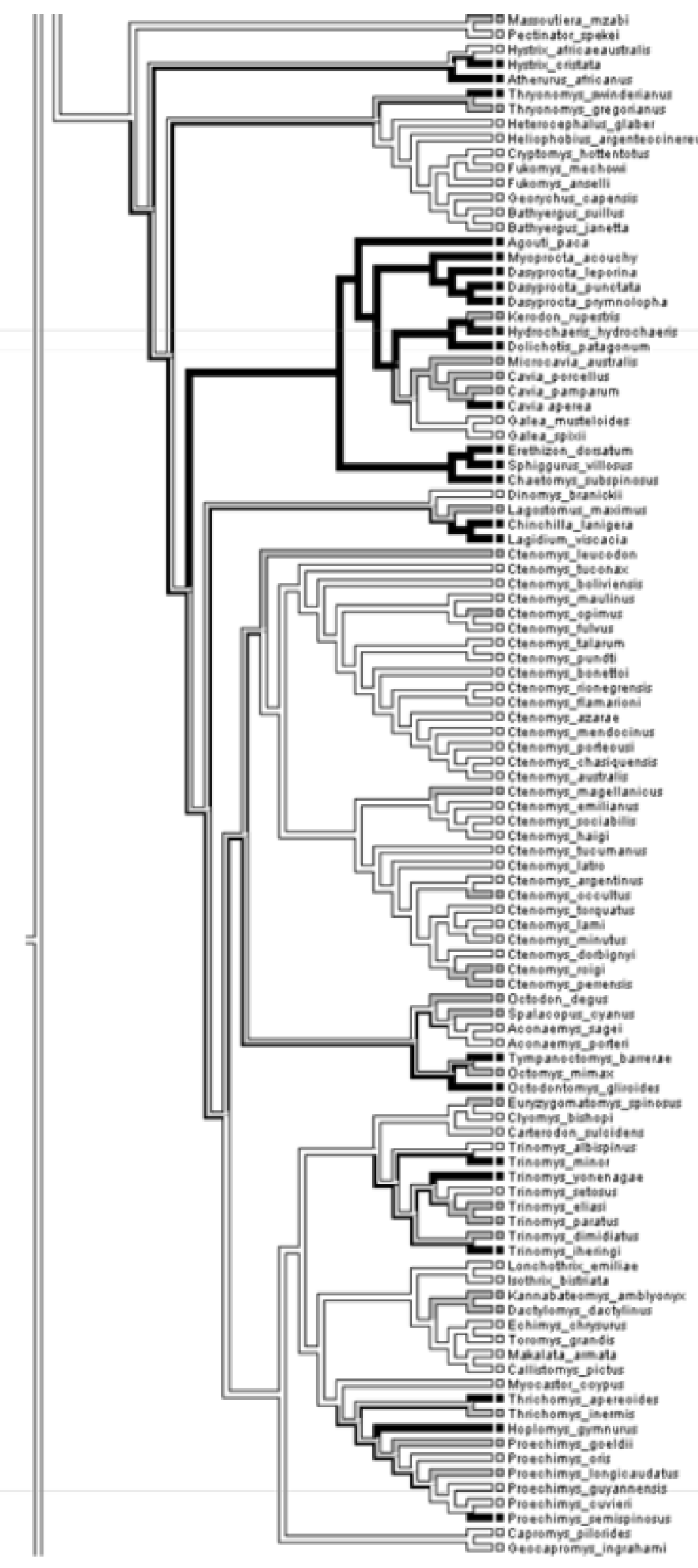

Figura 6. Filogenia das 104 espécies de Hystricomorpha a partir da filogenia deste trabalho com o mapeamento pelo método da parcimônia do estado da encefalização baseada no quociente de encefalização (QE) discretizado em três níveis: 0 cor branca (QE 0-0.90); 1 cor cinza (QE 0.91-1.10) e 2 cor preta (QE>1.10). 


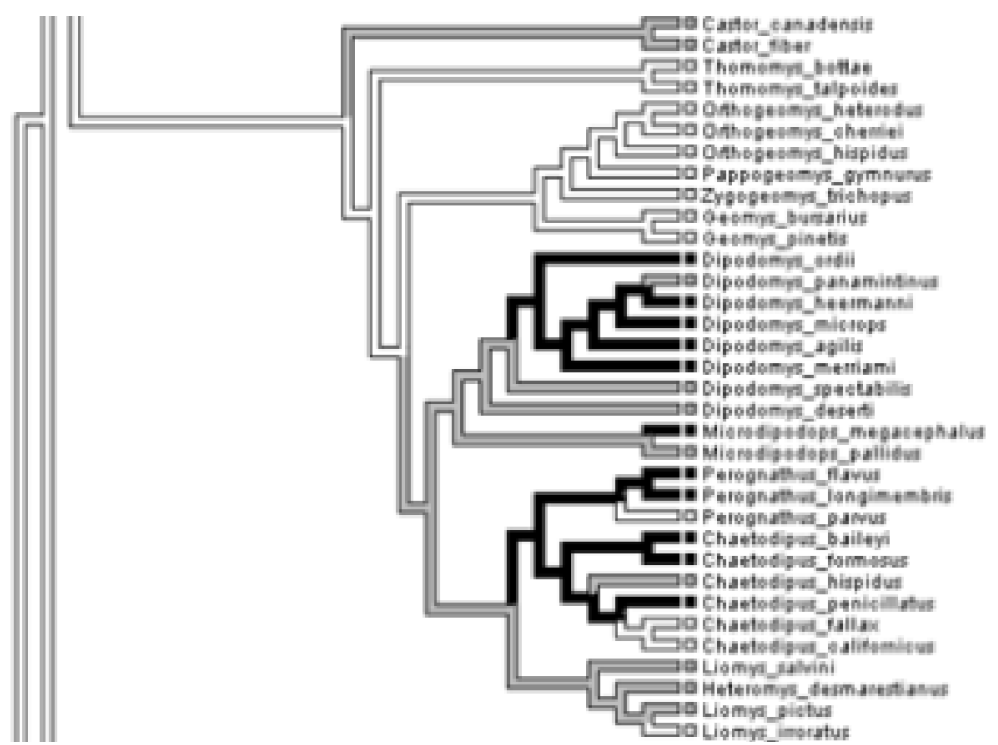

Figura 7. Filogenia das 34 espécies de Castorimorpha a partir da filogenia deste trabalho com o mapeamento pelo método da parcimônia do estado da encefalização baseada no quociente de encefalização $(\mathrm{QE})$ discretizado em três níveis: 0 na cor branca (QE 0-0.90); 1 cor na cinza (QE 0.91-1.10) e 2 cor na preta (QE >1.10). 


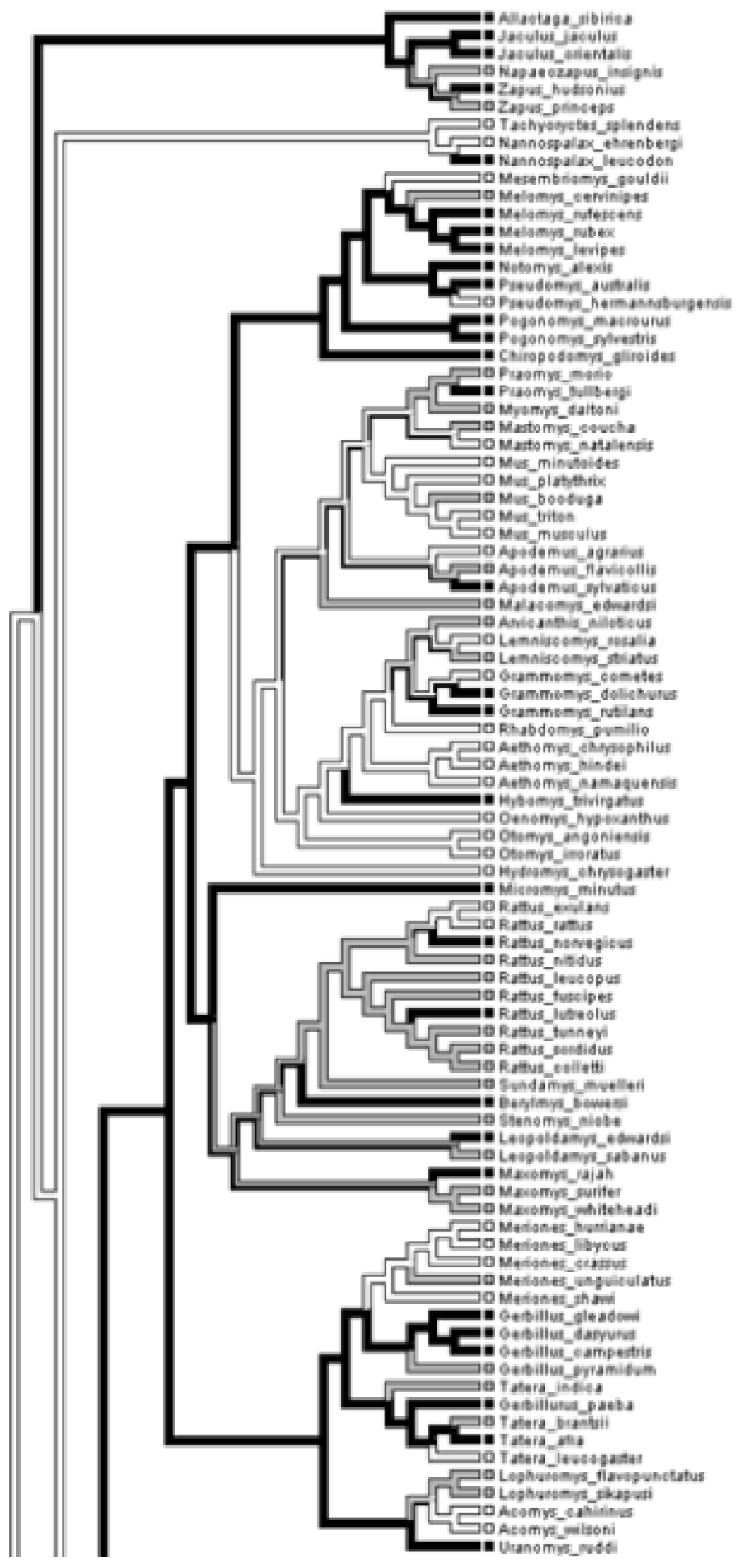

Figura 8. Filogenia das 167 espécies de Myomorpha com parte referente às famílias Dipodidae, Spalacidae e Muridae a partir da filogenia deste trabalho com o mapeamento pelo método da parcimônia do estado da encefalização baseada do quociente de encefalização $(\mathrm{QE})$ discretizado em três níveis: 0 na cor branca $(\mathrm{QE}$ 0-0.90); 1 na cor cinza (0.91-1.10) e 2 na cor preta $(>1.10)$. 


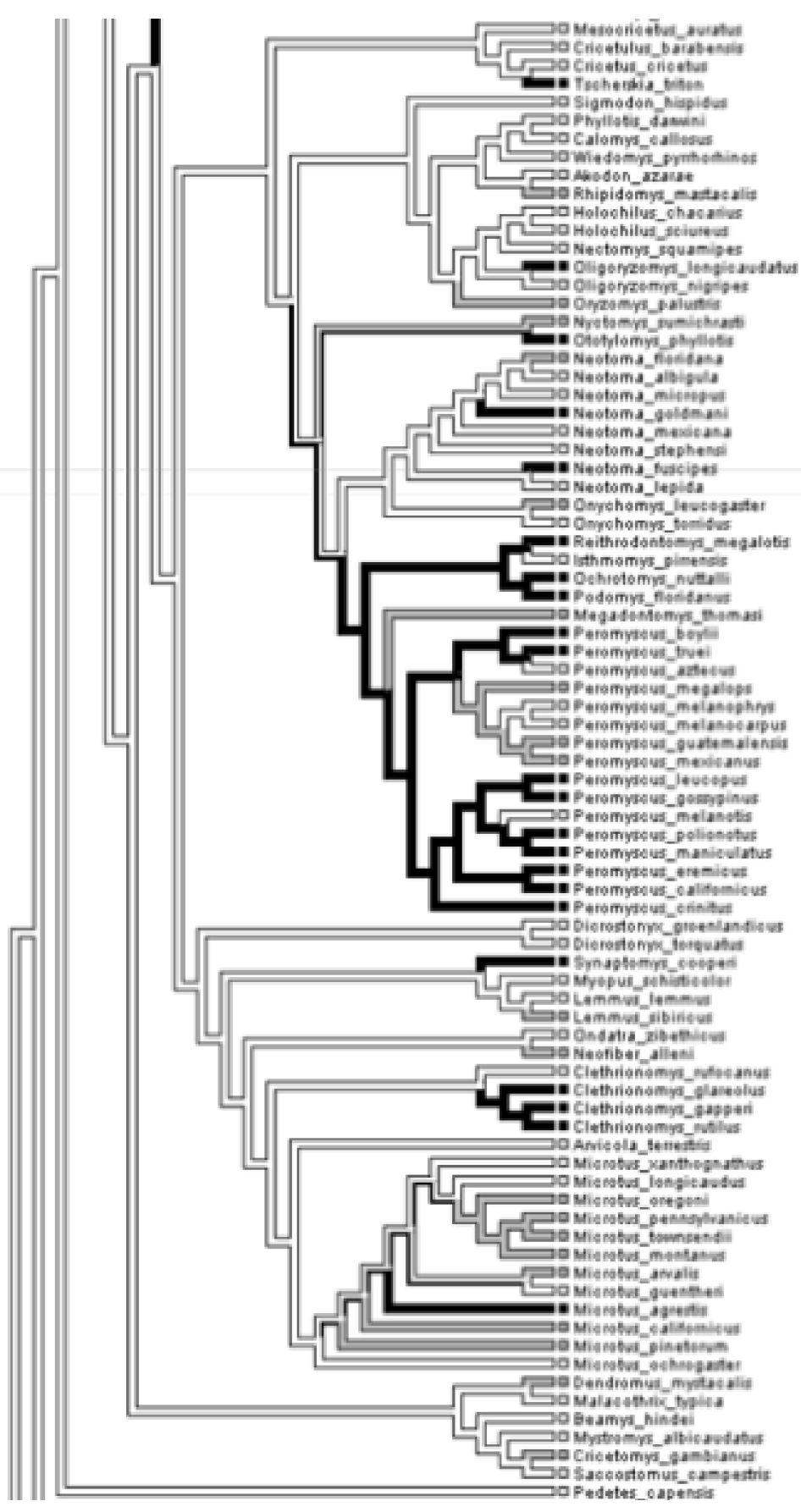

Figura 9. Filogenia das 167 espécies de Myomorpha, com parte referente a Cricetidae e Nesomyidae, alem de incluir Anomalurimorpha a partir da filogenia deste trabalho com o mapeamento pelo método da parcimônia do estado da encefalização baseada do quociente de encefalização (QE) discretizado em três níveis: 0 na cor branca (QE 0-0.90); 1 na cor cinza $(0.91-1.10)$ e 2 na cor preta $(>1.10)$. 
No UAC da super-família Muroidea o QE inferido foi do nível 0. Este nível é mantido no UAC das famílias Spalacidae, Nesomyidae, Cricetidae, enquanto que houve uma mudança para nível 2 no UAC da família Muridae. Na categoria de sub-famílias, Dentro da familia Cricetidae podemos destacar a manutenção do nível 0 nas sub-famílias Cricetinae, Sigmodontinae e Arvicolinae enquanto que Neotominae e Tylomyinae apresentam resultado ambíguo quanto ao estado ancestral do caráter. Com relação afamilia Muridae, as subfamílias Deomyinae, Gerbilinae e Murinae mantem o estado do UAC da família, por outro lado a sub-família Otomyinae apresentou um reversão com o estado nível 0.

Dentre os cincos clados, Sciuromorpha apresentou em média $(1.35 \pm 0.33)$ os maiores valores de QE que testado em ANOVA de um fator foi detectada diferença significativa (F: 34.81; $\mathrm{p}<$ 0.0000) em relação aos clados Myomorpha (0.98 \pm 0.28$)$, Castorimorpha $(0.99 \pm 0.23)$ e

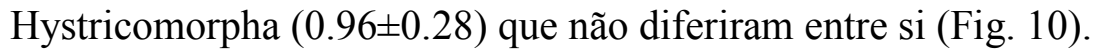

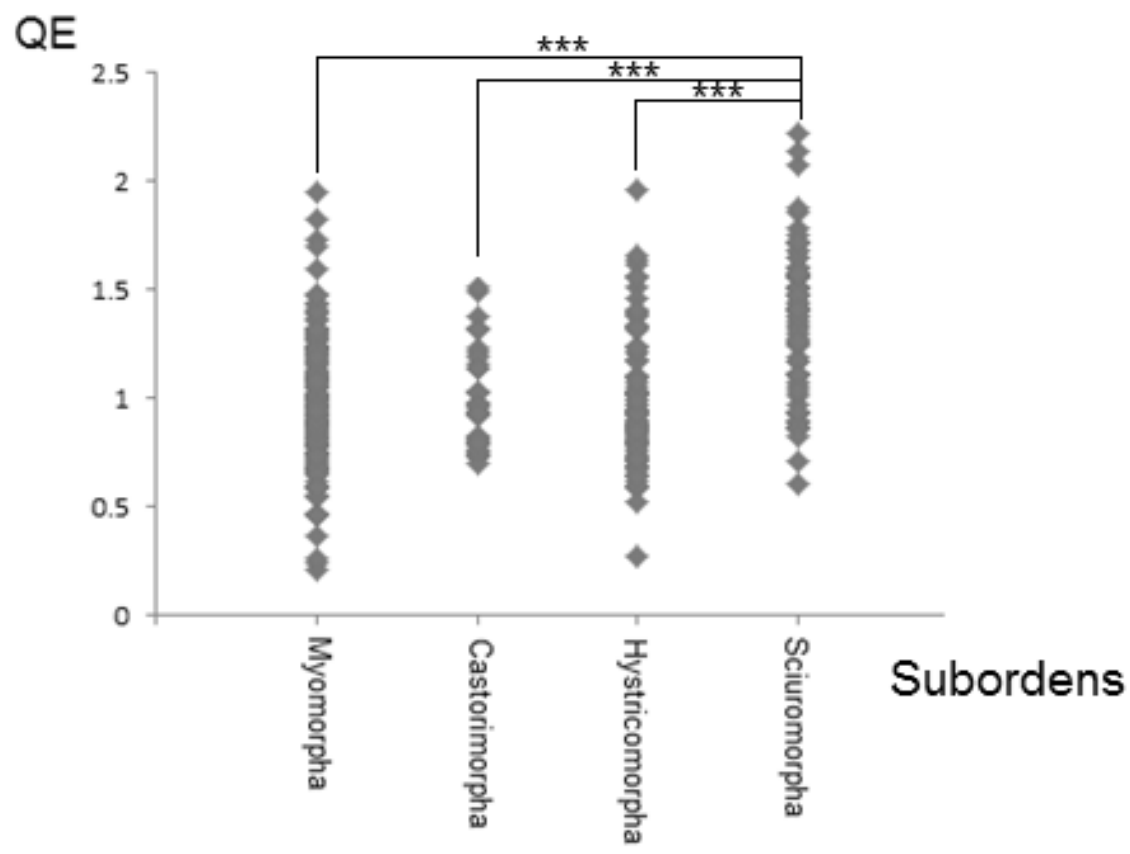

Figura 10. Variação do quociente de encefalização em quatro clados de Rodentia (Myomorpha, Castorimorpha, Hystricomopha e Sciuromorpha). Diferenças significativas detectadas pelos teste de comparação multipla de Tukey entre os níveis do fator: ${ }^{*} \mathrm{p}<0.05 ; * * \mathrm{p}<0.01 ; * * * \mathrm{p}<0.001$. 


\section{Análise dos fatores ecológicos, sociais e do desenvolvimento}

\section{Habitat}

No fator habitat, os valores médios e de desvio padrão do QE bruto para espécies foram de $1.20 \pm 0.35$ para habitat florestado, $1.01 \pm 0.33$ para misto e $0.96 \pm 0.96$ para aberto. $O$ teste de homocedasticidade de Levene não detectou diferença significativa entre as variâncias dos níveis do fator $(F=2.52 ; p=0.082)$. A analise não detectou diferença significativa no contrastes filogenéticos do QE das espécies de roedores entre os três niveis do fator habitat: (ANOVA: F = 2.433; $p=0.089$; Welch: $F=3.037 ; p=0.05$; Brown-Forsythe: $F=2.592 ; p=0.076)$ (Fig. 11).

\section{Contrastes}

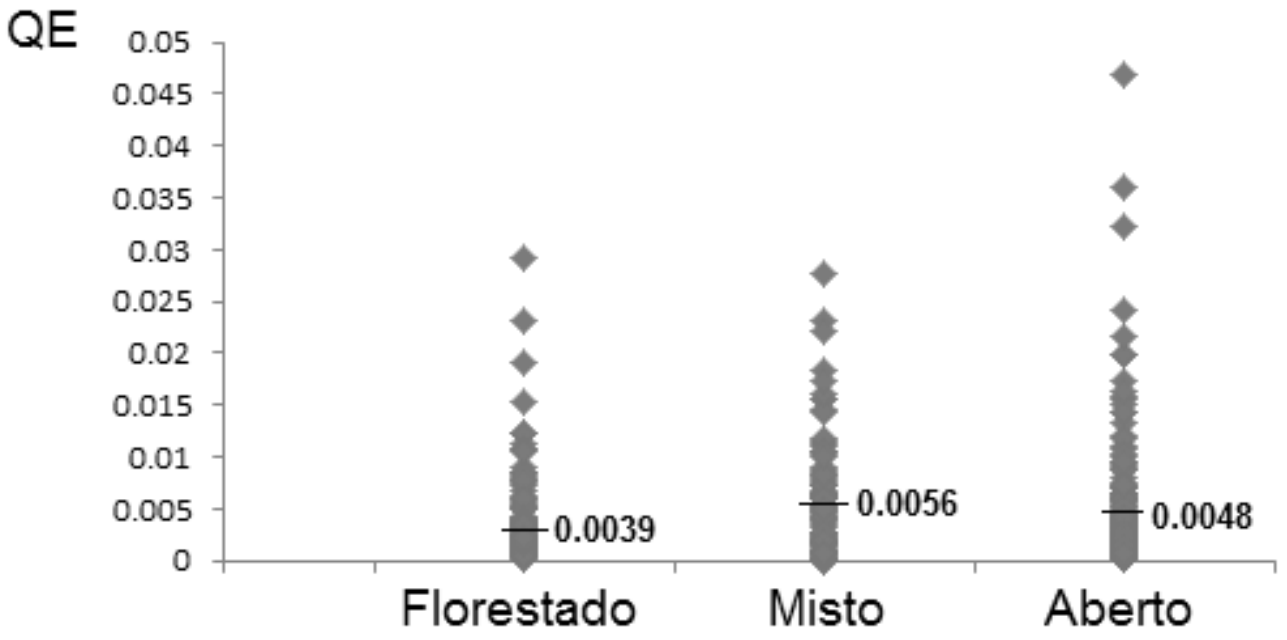

Habitat

Figura 11. Variação dos contrastes filogenéticos do quociente de encefalização com as médias (C-QE) pelo fator habitat nos níveis florestado, misto e aberto. Diferenças significativas detectadas pelos teste de comparação multipla de Tukey entre os níveis do fator: ${ }^{*} \mathrm{p}<0.05 ; * * \mathrm{p}<0.01 ; * * * \mathrm{p}<0.001$. 


\section{Uso do habitat}

No fator uso do hábitat, os valores médios e de desvio padrão do QE bruto para espécies foram de $1.02 \pm 0.29$ para hábito terrestre, $1.06 \pm 0.30$ para semi-fossorial, $0.93 \pm 0.16$ para fossorial, $0.79 \pm 0.17$ para subterrâneo, $0.95 \pm 0.26$ para semi-aquático, $1.29 \pm 1.05$ para arborícola. $\mathrm{O}$ teste de homocedasticidade de Levene detectou diferença significativa entre as variâncias dos níveis do fator $(\mathrm{F}=9.60 ; \mathrm{p}<0.000)$. A análise detectou diferença significativa no contrastes filogenéticos do QE das espécies de roedores entre os seis niveis do fator uso do hábitat: (ANOVA: $\mathrm{F}=6.061$; $\mathrm{p}=0.00002$; Welch: $\mathrm{F}=72.848 ; \mathrm{p}=0.90$; Brown-Forsythe: $\mathrm{F}=293.215 ; \mathrm{p}=0.0000000005)$. Os resultados do teste de comparação múltipla estão representados na Figura 12. Na qual as espécies terrestres diferem significativamente apenas das subterrâneas e estas diferem das semi-fossoriais que diferem das semi-aquáticas.

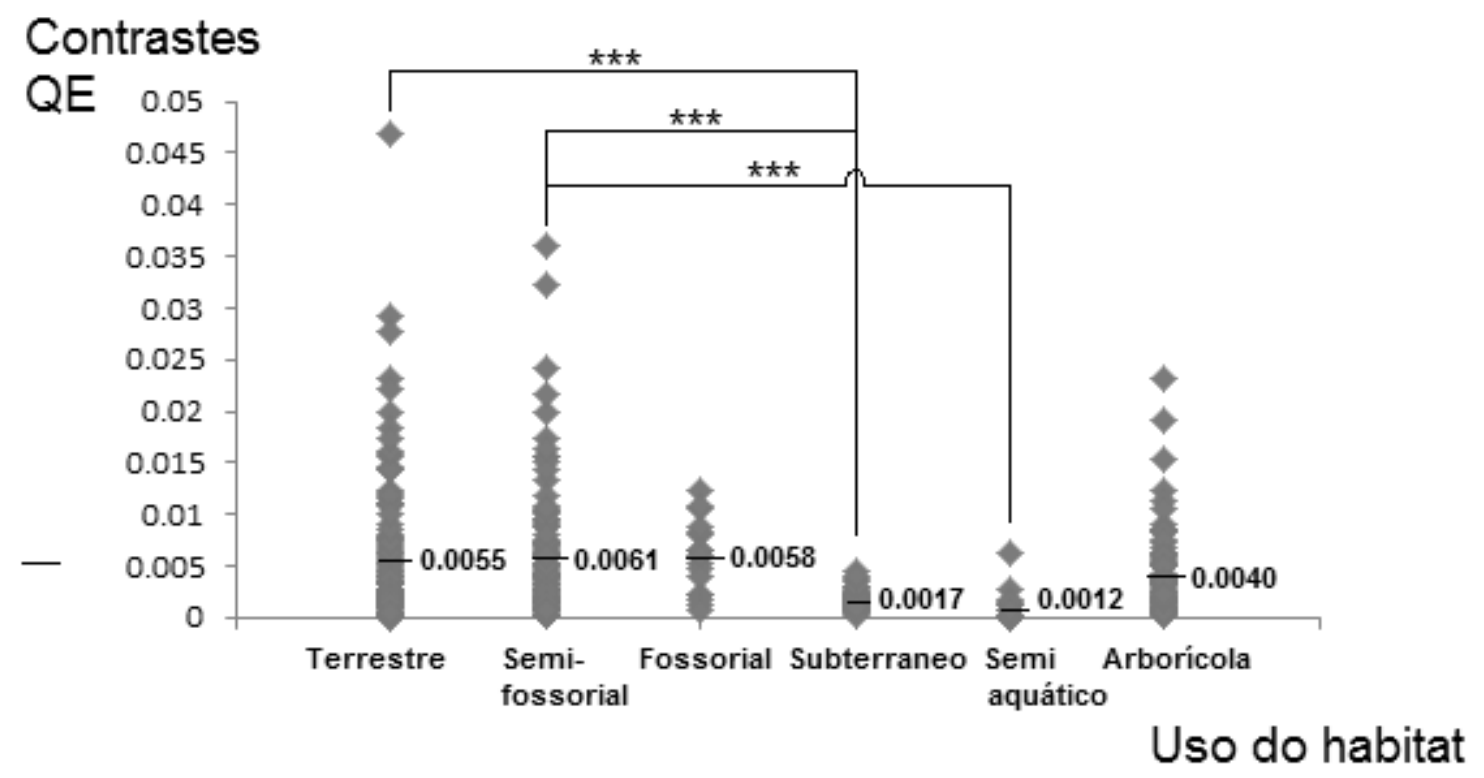

Figura 12. Variação dos contrastes filogenéticos do quociente de encefalização (C-QE) pelo fator hábito nos níveis terrestre, semi-fossorial, fossorial, subterrâneo, semi-aquático e arborícola. Diferenças significativas detectadas pelos teste de comparação multipla de Tukey entre os níveis do fator: * $\mathrm{p}<0.05 ; * * \mathrm{p}<0.01 ; * * * \mathrm{p}<0.001$. 


\section{Tipo de dieta}

No fator tipo de dieta, os valores médios e de desvio padrão do QE bruto para espécies foram de $1.00 \pm 0.23$ para dieta animal, $1.14 \pm 0.34$ para omnívora, $1.04 \pm 0.21$ para herbívora pobre, $1.06 \pm 0.41$ para herbívora rica e $0.93 \pm 0.25$ para herbivora generalista,. $O$ teste de homocedasticidade de Levene detectou diferença significativa entre as variâncias dos níveis do fator $(\mathrm{F}=19.49 ; \mathrm{p}<0.000)$. A análise detectou diferença significativa no contrastes filogenéticos do QE das espécies de roedores entre os cinco niveis do fator tipo de dieta: (ANOVA: $\mathrm{F}=$ 12.073; $\mathrm{p}=0.0000000003 ;$ Welch: $\mathrm{F}=34.899 ; \mathrm{p}=0.0000000001 ;$ Brown-Forsythe: $\mathrm{F}=73.704$; $\mathrm{p}=0.000000006)$. Os resultados do teste de comparação múltipla estão representados na Figura 13, no qual, as espécies omnívoras diferem significativamente das herbívoras generalistas e pobres que por sua vez diferem das espécies herbívoras ricas que diferem das herbívoras generalistas.

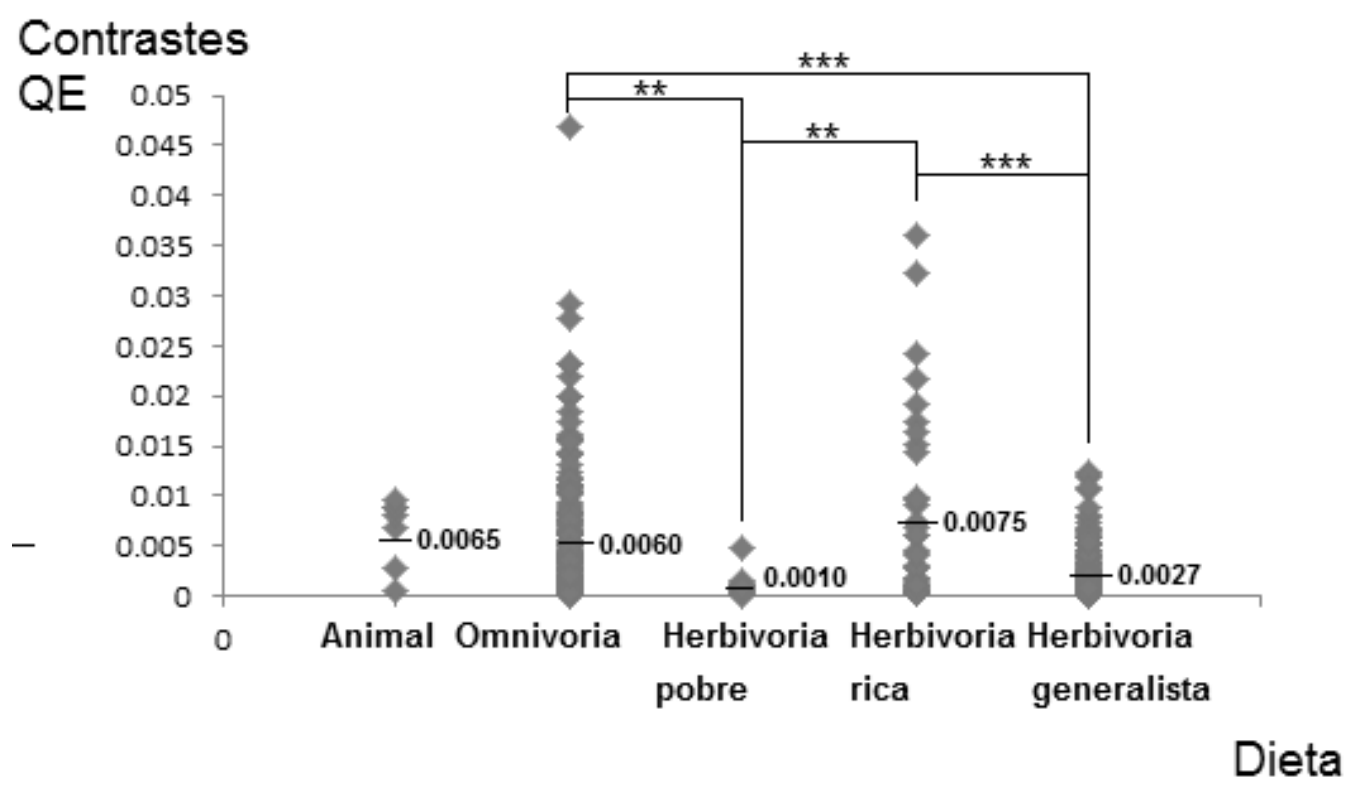

Figura 13. Variação dos contrastes filogenéticos do quociente de encefalização (C-QE) pelo fator dieta nos níveis animal, omnivoria, herbivoria pobre, herbivoria rica, herbivoria e generalista. Diferenças significativas detectadas pelos teste de comparação multipla de Tukey entre os níveis do fator: ${ }^{*} \mathrm{p}<0.05 ; * * \mathrm{p}<0.01 ; * * * \mathrm{p}<0.001$. 


\section{Atividade temporal}

No fator atividade temporal, os valores médios e de desvio padrão do QE bruto para espécies foram de $1.02 \pm 0.26$ para atividade noturna, $0.89 \pm 0.25$ para quetameral e $1.23 \pm 0.42$ para diurna. O teste de homocedasticidade de Levene detectou diferença significativa entre as variâncias dos níveis do fator $(\mathrm{F}=10.54 ; \mathrm{p}<0.000)$. A análise detectou diferença significativa nos contrastes filogenéticos do QE das espécies de roedores entre os três níveis do fator tipo de atividade temporal: (ANOVA: $F=10.872 ; p=0.000025$; Welch: $F=177.773 ; p=0.000000013$; BrownForsythe: $\mathrm{F}=194.034 ; \mathrm{p}=0.00000073)$. Os resultados do teste de comparação múltipla estão representados na Figura 14, no qual as espécies noturnas diferem significativamente das espécies diurnas e quetamerais.

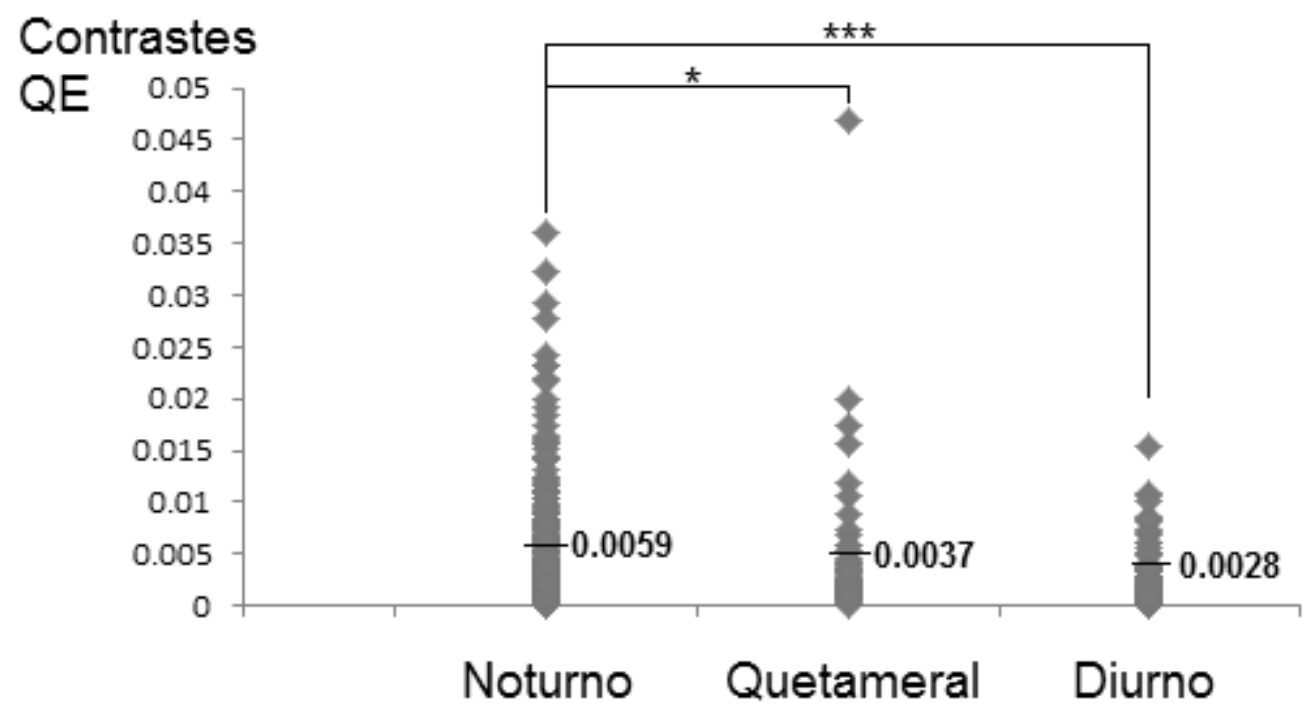

Atividade temporal

Figura 14. Variação dos contrastes filogenéticos do quociente de encefalização (C-QE) pelo fator atividade temporal nos níveis noturno, quetameral e diurno. Diferenças significativas detectadas pelos teste de comparação multipla de Tukey entre os níveis do fator: ${ }^{*} \mathrm{p}<0.05 ; * * \mathrm{p}<0.01 ; * * \mathrm{p}<0.001$. 


\section{Sociabilidade}

No fator tipo de sociabilidade, os valores médios e de desvio padrão do QE bruto para espécies foram de $1.05 \pm 0.32$ para espécies solitárias, $1.15 \pm 0.33$ para semi-sociais e $1.02 \pm 0.30$ para sociais. O teste de homocedasticidade de Levene não detectou diferença significativa entre as variâncias dos níveis do fator $(\mathrm{F}=0.15 ; \mathrm{p}=0.861)$. A análise não detectou diferença significativa nos contrastes filogenéticos do QE das espécies de roedores entre os três niveis do fator tipo de sociabilidade: (ANOVA: $\mathrm{F}=0.335 ; \mathrm{p}=0.715 ;$ Welch: $\mathrm{F}=183.234 ; \mathrm{p}=0.710$;

Brown-Forsythe: $F=262.147 ; p=0.718)($ Fig. 15).

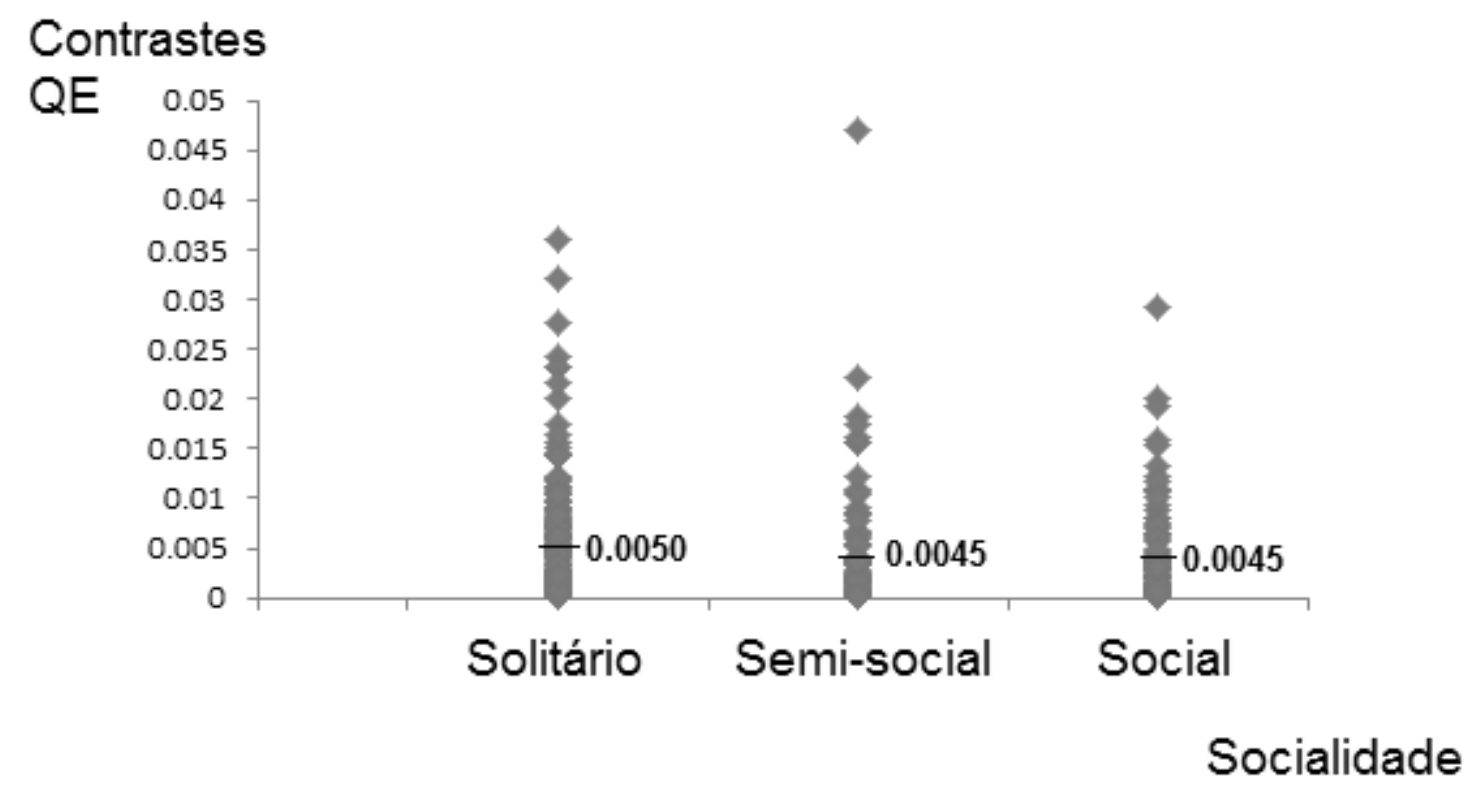

Figura 15. Variação dos contrastes filogenéticos do quociente de encefalização (C-QE) pelo fator sociabilidade nos níveis solitário, semi-social e social. Diferenças significativas detectadas pelos teste de comparação multipla de Tukey entre os níveis do fator: $* \mathrm{p}<0.05 ; * * \mathrm{p}<0.01 ; * * * \mathrm{p}<0.001$. 


\section{Estágio de desenvolvimento do neonato}

No fator estágio de desenvolvimento do neonato, os valores médios e de desvio padrão do QE bruto para espécies foram de $1.08 \pm 0.34$ para neonato altricial e $0.96 \pm 0.27$ para precocial. $\mathrm{O}$ teste de homocedasticidade de Levene detectou diferença significativa entre as variâncias dos níveis do fator $(\mathrm{F}=56.72 ; \mathrm{p}<0.000)$. A análise detectou diferença significativa no contrastes filogenéticos do QE das espécies de roedores entre os dois níveis do fator estágio de desenvolvimento do neonato: (ANOVA: $\mathrm{F}=49.513 ; \mathrm{p}=0.00000000000009$; Welch: $\mathrm{F}=$ 341.495; $\mathrm{p}<0.000000000000$; Brown-Forsythe: $\mathrm{F}=341.495 ; \mathrm{p}<0.0000000000)$ (Fig. 16).

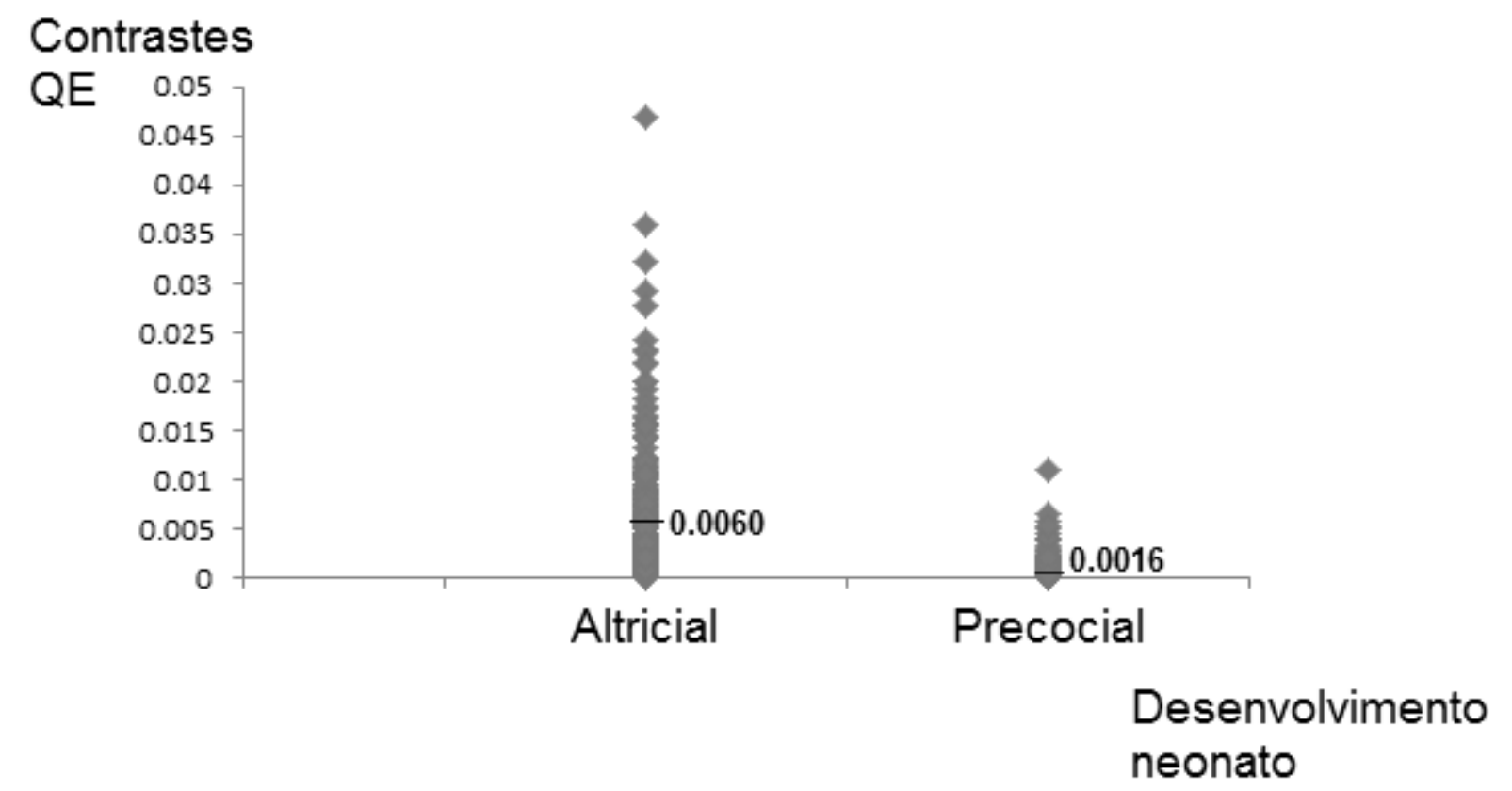

Figura 16. Variação dos contrastes filogenéticos do quociente de encefalização (C-QE) pelo fator desenvolvimento do neonato nos níveis altricial e precocial. Diferenças significativas detectadas pelos teste de comparação multipla de Tukey entre os níveis do fator: ${ }^{*} \mathrm{p}<0.05 ; * * \mathrm{p}<0.01 ; * * \mathrm{p}<0.001$. 


\section{DISCUSSÃO}

\section{Mapeamento e reconstrução do estado ancestral}

Este trabalho avaliou dados de aproximadamente $17 \%$ da diversidade de roedores dos cinco clados de Rodentia (WILSON \& READER 2005): Myomorpha (167spp), Castorimorpha (34spp), Anomalurimorpha (1spp), Hystricomorpha (104spp) e Sciuromorpha (76spp). Esta diversidade de espécies avaliada foi mais abrangente em termos ecológicos (incluindo mais espécies neotropicais do clado Hystrimorpha) e superior ao número de espécies de roedores utilizado nos trabalhos de Mace et al com 219 espécies (1981), Sobrero et al com 132 espécies (2011) e de Boddy et al (2012) que de 630 espécies de mamíferos, utilizou 258 espécies.

A encefalização está fundamentada na relação escalar entre massa do encéfalo pela massa do corpo que são as duas variáveis que ajudam a determinar o quociente de encefalizaçào $(\mathrm{QE})$ nos mais diversos trabalhos sobre evolução da encefalização (JERISON 1973; MACE ET AL 1981). O QE proposto por Jerison (1973) dentre as outras estimativas da encefalização apresenta a vantagem de reunir os dados de razão e resíduos do tamanho do encéfalo e do corpo. Nosso QE foi gerado a partir dos resíduos das espécies de Rodentia plotados num gráfico de dispersão dos pontos, o que permitiu gerar a equação da linha de regressão da encefalização com tendência positiva e significante, e no qual ficou demonstrado que o tamanho do encéfalo tende a aumentar menos que o tamanho do corpo. O expoente alométrico no valor de 0.584 quando comparado com dados da literatura, ficou acima do de 0.50 obtido para roedores do gênero Ctenomys (Ctenomyidae: Hystricomorpha) (VASSALlO ET AL 2008), cuja a ecologia é estritamente subterrânea e abaixo do valor de 0.746 do recente trabalho de Boddy et al (2012) com 630 espécies de mamíferos que inclue 21 ordens inclusive Rodentia, que por sua vez é quase o valor do 0.76 proposto por Martin (1981) no seu trabalho sobre o tamanho relativo do encéfalo e taxa 
metabólica basal. Mas afinal quais seriam as explicações para esta variação no valor do expoente alométrico? Como aventado anteriormente, as duas vertentes mais bem estabelecidas são do expoente de 2/3 ou 0.66 (SNELL, 1891 APUD JERISON, 1973), que produz a equação EQ = $\mathrm{ME} / 0.12 * \mathrm{MC}^{0.66}$ (Jerison, 1973), e a do expoente de 3/4 (0.76) (PilbeAm \& Gould, 1974, MARTIN, 1981), que produz a equação $\mathrm{EQ}=\mathrm{ME} / 0.059 * \mathrm{MC}^{0,76}$ (MARTIN, 1984). A hipótese do expoente de $2 / 3$ é derivada da expectativa teórica da massa do cérebro escalonar com o corpo área da superfície corpórea (SNELL 1891 APUD JERISON 1973). A 3⁄3 expoente é baseado em um ajuste empírico para grandes conjuntos de dados entre espécies que parece estar de acordo com a hipótese da relação da massa cerebral com taxa metabólica basal. Isto é, uma espécie de grande encefalização é dependente da energia materna disponível durante a gestação para o desenvolvimento do neonato (MARTIN, 1981; MARINO, 1998). Com base no nosso resultado para o expoente alométrico e nas duas hipóteses explicativas, podemos sugerir que quando avaliada de maneira isolada, a ordem Rodentia tem uma encefalização mais relacionada com a proposta da relação área da superfície do corpo com o tamanho do encéfalo proposta por Jerison (1973) do que com a proposta da relação do tamanho de encéfalo com a taxa metabólica basal (MARTIN 1981; MARINO 1998). Além disso, os quocientes de encefalização gerado dos nossos dados permitiram que aquelas espécies que apresentassem maiores massas corpóreas e menor relação área-volume dentre os roedores (ex: Hydrochaerus, Cuniculus, Dasyprocta) também apresentassem maiores valores de QE quando comparado aos QEs das mesmas espécies obtidos a partir de linhas de regressão com toda a diversidade de Mammalia.

Os estudos comparativos com grande número de espécies permitem o cálculo do sinal filogenético. $\mathrm{O} Q \mathrm{QE}$ testado neste trabalho apresentou sinal filogenético tanto no $\mathrm{K}$ de Blomberg quanto no Lambda de Pagel, sendo que o valor deste último foi maior que o primeiro, 
demonstrando uma maior estruturação da encefalização na filogenia e portanto menos próxima de uma filogenia estrela (star-phylogeny). Por isso os testes de hipóteses deverão levar em consideração o efeito da filogenia sobre os dados aplicando-se a metodologia comparativa filogenética de forma a evitar a pseudoreplicação filogenética nos testes de hipóteses.

O mapeamento e a reconstrução da ancestralidade da encefalização em Rodentia realizados neste trabalho inferiu que o último ancestral comum do grupo apresentou um valor de QE abaixo do esperado para o tamanho do corpo considerando o método da parcimônia com dados discretizados, este valor foi abaixo da média do clado Euarchontoglires (Primates, Dermoptera, Scandentia, Lagomorpha e Rodentia) e da ordem Rodentia que apresentou o valor de 0.98 no trabalho de Boddy et al (2012) que pela classificação deste trabalho fica dentro da categoria esperada para o tamanho do corpo.

$\mathrm{Na}$ filogenia de Rodentia utilizada para este trabalho (BININDA-EMONDS ET AL 2007), a encefalização para além do esperado do tamanho do corpo já está presente nos grupos mais basais de Rodentia (NOWAK 1999), como no clado Sciuromorpha que reúne espécies de esquilos, marmotas, cães-da-pradaria (familia Sciuridae), castores-da-montanha (familia Aplodontidae) e arganazes (familia Gliridae). A família Sciuridae originou-se na América do Norte no final do Eoceno (35 milhões de anos) e tinha uma distribuição holárctica no início do Oligoceno (THORINGTON ET AL. 1997); Os estoques ancestrais entraram África, partes do sudeste da Ásia, e mais recentemente na América do Sul. Hoje é o segundo grupo mais diversificado de roedores e é distribuída em todo o mundo, com exceção de Madagascar, Austrália e regiões do sul da América do Sul (HofFMAnN ET AL., 1993). Na base da sua origem até a distribuição atual, é provável que o ancestral do grupo já apresentasse encefalização maior que o esperado, isto parece ter refletido no valor médio da encefalização do grupo, pois dentre os cincos clados, 
Sciuromorpha apresentou valores de QE acima do esperado em média em relação aos clados Myomorpha, Castorimorpha e Hystricomorpha que estiveram dentro de um QE esperado. É possivel que a encefalização acima do esperado já estivesse associada ao hábito arborícola presente no ancestral de Sciuridae, por outro lado, os gêneros associadas aos hábitos terrestres e semi-fossoriais como na tribo Marmotini, representada por Tamias, Ammospermophilus, Spermophilus, Cynomys e Marmota apresentaram eventos de reversão ao estado ancestral de Sciuromorpha, sendo o mais destacado no gênero Spermophilus. Em termos de sociabilidade, os gêneros Cynomys e Marmota se destacam por apresentar espécies que vivem em habitats de fisionomia vegetal aberta e em grupos sociais. Na espécies de Marmota, as espécies mais sociais, tais como M. sibirica e M. marmota tenderam a apresentar maior encefalização do que as espécies menos sociais tais como M. Flaviventris. Além disso, segundo Kruckenhauser e colaboradores (1999) a alta sociabilidade aparece duas vezes no gênero Marmota, mas na ausência de outras espécies com M. olympus e M. caligata não podemos conjecturar se a sociabilidade está relacionada ao aumento da encefalização. Assim estes dados sugerem uma possível relação do aumento da sociabilidade e vida em habitat abertos com a evolução da encefalização para alguns gêneros de Sciuridae, mas não para a vida em ambientes abertos e a atividade diurna do grupo.

O ancestral comum de Sciuridae e da família Aplodontidae já compartilhava o mesmo nível de encefalização acima do esperado, o castor-da-montanha (Aplodontia rufa) é o único representante atual da familia e apresenta o hábito de vida fossorial pois habita extensos túneis em meio a florestas em áreas de montanha na América do Norte (NOWAK 1999; HOPKINS ET AL 2008). A familia Aplodontidae é considerada a mais basal de Rodentia (Hutchins et al 2003), e os fósseis que antecederam os Aplodontidae aparentavam serem de pequeno porte e semelhantes 
a esquilos. Pouco diferentes de seus ancestrais Paramydae, haviam também formas arborícolas frugívoras (semelhantes a esquilos voadores), pequenos escavadores e dois diferentes grupos de escavadores de grande porte, um que ocorria em ambientes abertos do oeste da America do Norte (Mylagaulidae) e outro deu origem aos Aplodontidae atuais (BENTON 2005). Assim as condições arborícolas e fossoriais poderiam ter mantido a encefalização acima do esperado ou haveria uma tendência mais para hábito arborícola devido ao tipo de complexidade ambiental da vida em árvores e a necessidade de localização especial necessaria na dieta frugívora, assim para se entender o estado ancestral nos primeiros fósseis é necessario realizar estudo de tamanho encefalico nos mesmos.

A família Myoxidae ou Gliridae dos arganazes é uma familia que é clado irmão de Aplodontidae e Sciuridae, tem representantes em sua maioria arborícolas e alguns terrestres (NOWAK 1999) e ao contrário de Sciuridae, este clado tem último ancestral comum com $\mathrm{QE}$ menor que o esperado, mas nosso trabalho utilizou apenas duas espécies ambas arborícolas, sugerindo que o ancestral deste grupo seja tambem arborícola.

A subordem Hystricomorpha é composta pelos os clados Hystricognathi e Ctenodactylomorphi (WILSON \& REEDER 2005) representa um grupo monofilético (LUCKETT E HARTENBERGER 1993; Nedbal et ai 1996,. Huchon et ai 2000,. AdKins et ai 2001,. Huchon e Douzery 2001; FABRE ET AL 2012), contendo 18 das 33 famílias existentes de roedores e $10 \%$ das espécies (WILSON \& REEDER 2005). Em termos de ecologia e comportamento, os membros desta subordem exibem uma grande diversidade de sistemas de acasalamento (monogâmica, poligâmica, poliândrico e promíscuo), mantém estilos de vida que vão desde solitária para viver em grupo (por exemplo, o eusocial toupeira-rato, Heterocephalus glaber), e ocupam uma ampla gama de habitats (NOWAK 1999; HUTCHINS ET AL 2003). Nosso trabalho avaliou quase a metade 
da diversidade do grupo 104 de 229 espécies. O clado dos Ctenodactylomorphi que é grupo irmão de Hystricognathi, apresenta como representantes atuais roedores terrestres de pequeno porte que habitam áreas rochosas na África (NowAK 1999) apresentando encefalização abaixo do esperado. Para os Hystricognathi, o último ancestral comum pode ser tanto uma espécie com encefalização abaixo ou acima do esperado de acordo com análise, seu fossil mais antigo poderia ser caracterizada como uma espécie de hábito terrestre como Sivacanthion de forma semelhante aos porcos-espinho atuais (BENTON 2005), portanto um animal de porte médio e de habitat misto . A encefalização acima do esperado evoluiu inúmera vezes, principalmente nos Caviomorphos sul-americanos que foi o grupo que ocupou a América do Sul no Oligoceno e sofreu uma grande irradiação adaptativa (HUTCHINS ET AL 2003; GALEWSKI ET AL 2006). O clado que reúne as famílias Erethizontidae, Caviidae, Hydrochaeridae, Dolichotidae, Dasyproctidae e Cuniculidae apresentaram uma encefalização acima do esperado a partir do último ancestral comum. Excetuando Caviidae que é de pequeno porte e apresenta encefalização abaixo do esperado, este clado se destaca pelo tamanho corpôreo acima de $1 \mathrm{~kg}$ podendo chegar até $70 \mathrm{Kg}$ com Hydrochaerus hidrochaeris. Em termos ecológicos, suas espécies variam de ambientes abertos e florestados, podendo ser terrestres cursores, semiaquáticos e arborícolas. Em termos sociais, existe uma variação que vai de grupos sociais com multi-fêmeas, par monogâmico e solitários. Assim o alto quociente de encefalização destas espécies aparentemente não indicaria relação com condições ecológicas e sociais, podendo estar relacionado ao tamanho corpôreo e ao grau de relacionamento filogenético entre estas espécies.

Os outros eventos de encefalização acima do esperado surgem de maneira pontual em espécies da família Chinchillidae, Octodontidae e Echimyidae, Nestas três familias podemos observar que a maioria das espécies com alta encefalização tem em comum a vida em habitat aberto ou misto, 
situadas em áreas semi-áridas e áridas (ex: Spalacopus cyanus, Tympanoctomys e Trinomys yonenagae) e algumas apresentam indícios de sociabilidade. Estas duas características apresentam componentes que favorecem a evolução da encefalização. Já a familia Capromyidae que se caracteriza por espécies semi-arborícolas apresentou QE abaixo do esperado. As familias com uso de habitat do tipo fossorial e subterrâneo como Ctenomyidae e Octodontidae e as espécies arborícola como algumas da família Echimyidae apresentaram encefalização abaixo do esperado sugerindo uma possível tendência a baixa encefalização principalmente no hábito fossorial.

O clado Castorimorpha reúne três famílias que em termos ecomorfológicos são notadamente distintas: Castoridae (castor) Geomyidae (rato-touperia-de-bolsa) e Heteromyidae (Ratoscangurus). Nos avaliamos 34 espécies e foi inferido uma encefalização abaixo do esperado para o último ancestral comum do clado. A condição de encefalização acima do esperado evoluiu três vezes com cinco eventos de reversão. A família Castoridae apresenta evento de encefalização dentro do esperado para último ancestral comum quando este se separa do ancestral Myomorpha. O registro geológico da família se extende até o Oligoceno, no qual as espécies apresentavam hábito fossorial como o Daimonelix e Paleocastor que escavavam túneis com um formato helicoidal datados do Oligoceno e Mioceno. Mais tarde no Pleistoceno, o Castoroides se destacou pelo grande porte e pela dieta folívora pastadora (BENTON 2005), assim ao contrário dos castores atuais que são animais semi-aquáticos e construtores de diques, os fósseis de castores apresentaram características ecológicas e de dieta que sustentam uma encefalização abaixo do esperado. A família Geomyidae mantém abaixo do esperado para seu ultimo ancestral comum demonstrando que o clado já na base apresenta condição que foi importante para o sucesso na ocupação do nicho subterrâneo, assim como outras espécies de roedores fossoriais e subterrâneos 
de outras famílias. Enquanto que na família Heteromyidae surgem os eventos de encefalização acima do esperado, esta família se destaca por ter em sua maioria espécies de roedores com adaptações associadas aos ambientes xéricos de deserto, como a locomoção bípede saltatorial, excreção de urina concentrada, hábito semi-fossorial.

O clado Anomalurimorpha apresenta duas famílias com formas de vida bastante distintas: Pedetidae (lebre-saltadora) de hábito semi-fossorial e de locomoção bipede saltatorial e Anomaluridae (esquilos-planadores) de hábito arborícola planador (Nowak 1999), neste estudo foi avaliado apenas a espécie Pedetes capensis que apresenta encefalização abaixo do esperado, assim devido a ausência de outras espécies do grupo não foi possivel inferir o estado do ancestral comum principalmente para um grupo tão problematico em termos filogenéticos.

O clado Myomorpha é o mais especioso de Rodentia (NOWAK 1999), neste estudo foi o que apresentou mais espécies avaliadas (167 Spp). Aqui foi observado que o último ancestral comum foi inferido na condição de encefalização abaixo do esperado, semelhante a condição do ancestral de Rodentia. Os myomorpha surgiram no início do Eoceno, mas eles sofreram uma drástica irradiação a partir do Mioceno (NOWAK 1999; HutChINS 2003). Os primeiros Myomorphos foram os Eomyidae, a partir de meados do Eoceno para o Pleistoceno da Europa, Ásia e América do Norte (BENTON 2005). Seus fosseis apresentavam indícios de hábito planador, assim este hábito pode ter exigido uma encefalização abaixo do esperado, pois algumas formas atuais de roedores planadores possuem geralmente encefalização abaixo do esperado.

A condição acima do esperado evoluiu mais vezes do que qualquer outro grupo de roedores assim como as reversões, cabe destacar que segundo o estudo de Fabre et al (2012), este clado apresentou as maiores taxas de mudanças de diversificação que acabaramm refletindo maior numero de irradiação adaptativas quando comparado aos outros grandes clados de Rodentia. 
Portanto levanta-se a questão de que o aumento da encefalização poderia ter permitido a diversificação de mais espécies e ocupação de novos nichos, devido a possibilidade de melhor exploração do ambiente e a consequente ampliação das chances de sobrevivência.

No nível dos sub-clados, a partir do último ancestral comum (UAC) da super-família Dipodoidea apresenta o primeiro evento de encefalização acima do esperado. A superfamília Dipodoidea que constitui o grupo-irmão de Muroidea, são amplamente distribuídos na região Holárctica e apresentam basicamente três tipos ecomorfológicos. Camundongos (Sicista, subfamília Sicistinae) de pequeno-porte, não especializadas que vivem em uma ampla gama de habitats de floresta tundra à semi-desertos da Europa e Ásia; camundongos-saltadores (Gêneros Eozapus, Zapus e Napaeozapus, subfamília Zapodinae), que vivem em florestas, pastagens e prados, de distribuição disjunta na China e América do Norte e, finalmente, os jerboas (sub-famílias Allactaginae, Cardiocraniinae, Dipodinae, Euchoreutinae) são habitantes do deserto, especializada para locomoção bípede, especialmente na pata traseira (ZHANG ET AL 2013). Assim como a subfamília Dipomyinae (Heteromyidae: Castorimorpha) que apresenta espécies com especializações relacionadas ao ambiente xérico. Os Dipodidae também, mantém encefalização acima do esperado.

A super-família Muroidea apresenta a maior diversidade de espécies com $28 \%$ do total de Mammalia e é considerado mais especioso que muitas ordens de mamíferos (NowAK 1999; HutChins ET AL 2003). Sua encefalização a partir do seu último ancestral comum ficou abaixo do esperado assim com em Myomorpha. Este nível foi mantido no ancestral das três famílias: Spalacidae que representam o clado mais basal, apresenta espécies com especializações a vida subterrânea, e nas famílias Nesomyidae e Cricetidae que se destaca por apresentar uma diversificação biológica e ecológica tanto na Ásia, Europa quanto na América do Norte e do Sul, 
manteve a encefalização abaixo do esperado nas sub-famílias Cricetinae, Arvicolinae e Sigmodontinae.

Apesar da subfamilia sigmodontinae não se destacar em termos de encefalização acima do esperado, mas ela representa uma subfamília de Muridae do Novo Mundo que alguns tratamentos taxonómicos dividem em grupos sul-americanos e norte-americanos (CARLETON E Musser 1984; MusSer e CARLETON 1993). Os primeiros sigmodontinae na América do Sul aparecem entre 2 e 3 milhões de anos (SIMPSON, 1950 APUD HonEYCUTT ET AL 2007), e representam presumivelmente uma radiação adaptativa de um estoque norte americano que entraram na América do Sul após a formação da ponte de terra panamenha. Já nas subfamilias Neotominae e Tylomyinae apresentam resultado ambíguo quanto ao estado ancestral do caráter, mas com taxons com encefalização acima do esperado como nos gênero Peromyscus.

A família Muridae é a mais especiosa com $66 \%$ da diversidade de Rodentia contendo aproximadamente 1326 espécies subdivididas em 17 subfamílias (MUSSER \& CARLETON 1993), tem como representantes mais conhecidos os ratos (gênero Rattus) e camundongos (gênero Mus), ela apresentam a maior distribuição geográfica, sendo um componente significante da diversidade de mamíferos na maioria dos continentes e estando associado a uma ampla diversidade de habitats como resultado de uma ampla radiação adaptativa. Em termos de encefalização possui espeécies com QE acima de 2 vezes maior que esperado, como por exemplo o Micromys minutus que é um camundongo de campos abertos e dieta granívora (NOWAK 1999). A encefalização acima do esperado pode ter refletido na sua ampla distribuição mundial e diversificação.

Dentro de Muridae, a subfamília Gerbilinae apresenta encefalização acima do esperado desde do ancestral comum do grupo. Espécies desta família, como dos Gêneros Gerbillus, Gerbillurus e 
Tatera, se destacam por apresentar convergências adaptativas com outras espécies de ambiente desértico, evitando a perda de água, o estresse térmico, por ser ativo à noite e se refugiando durante o dia em tocas com alta umidade relativa do ar, e produzindo urina mais concentrada (NOWAK 1999; HUTCHINS ET AL 2003), portanto parece que a vida em ambientes xéricos gera demandas referentes ao aumento da encefalização, por outro lado a sub-família Otomyinae apresentou um reversão para encefalização abaixo do esperado, as espécies deste grupo são conhecidas por apresentar neonatos precociais e isto pode ser um indício para a afirmação de que espécies precocial apresentem encefalização dentro e abaixo do esperado quando adultos (MARTIN 1981), da mesma forma a sub-família Deomyinae também apresenta espécies precociais.

A sub-família Murinae é a maior em diversidade dentro de Muridae e que apresenta segundo Fabre et al (2012) o maior número de eventos de acelerações na taxa de diversificação dentro da família, a encefalização acima do esperado, presente desde o último ancestral comum do grupo poderia refletir a grande diversidade de espécies e ecomorfológica Assim fatores como mudanças climáticas, intercâmbios de faunas entre regiões biogeográficas e rápida subtituição de fauna em muitos continentes tem resultado em radiações adaptativas locais caracterizadas por especializações ecomorfológicas que por sua vez poderiam influenciar a evolução de encéfalos maiores.

No geral as cinco famílias de roedores com as maiores diversidades de espécies: Muridae, Sciuridae, Echimyidae, Heteromyidae e Dipodidae. Quatro apresentam altos QE em relação ao restante da ordem sugerindo uma relação entre diversidade, ocupação de nichos ecologicos e encefalização. Em termos das observações entre a variedade ecomorfológica e a evolução da encefalização temos casos emblemáticos em que o aumento da encefalização poderia está 
relacionada ao tipo de regime seletivo como nas espécies típicas de ambientes xéricos como do gênero Dipodomys (Heteromyidae: Castorimorpha) Allactaga (Dipodidae; Myomorpha) Gerbillus (Gerbillinae: Muridae: Myomorpha), Tympanoctomys (Octodontidae: Hystricomorpha) que são conhecidas por exibir homoplasias relacionadas à vida em ambientes xérico, tais como, locomoção saltatorial bípede e excreção de urina concentrada. Esta observação demandaria teste de hipótese sobre este fator e a encefalização das espécies Por outro lado, haveriam casos em que a baixa encefalização estaria relacionados a determinados tipos de ambiente, como foi observado em espécies fossoriais e subterraneas com o QE abaixo do esperado como nos gêneros Geomys (Geomyidae: Castorimorpha), Spalax (Spalacidae: Myomorpha) Fukomys (Bathyergidae: Hystricomorpha) e Ctenomys (Ctenomyidae: Hystricomorpha).

\section{Análise dos fatores ecológicos, sociais e do desenvolvimento}

Neste trabalho foram testados os seis principais fatores responsáveis por promover e controlar a evolução da encefalização em Mammalia, mas aplicados apenas as espécies da ordem Rodentia.

\section{Habitat}

O primeiro deles foi do tipo de habitat: categorizados em florestado, misto e aberto em relação a encefalização. Quando nos avaliamos os dados com efeito da filogenia, que não foram testados estatitisticamente, observamos que as espécies de habitat florestado apresentaram valores médios maiores que as espécies de habitat misto e estas foram maiores que aquelas de habitat aberto, no entanto quando associamos isso ao resultado médio por clado de Rodentia, podemos notar que o clado Sciuromorpha foi o que apresentou maior encefalização em relação aos outros clados Rodentia e este clado apresenta um grande número de espécies de áreas florestadas, além disso, 
outro clado como Myomorpha também apresenta sub-clado com valores de QE acima do esperado associados à floresta como a família Muridae, estes dados podem justificar a influência das relações filogenéticas sobre o resultado supracitados. Quando o efeito da filogenia é retirado pelos contrastes. A análise não detecta diferença significativa no QE das espécies de roedores entre os três niveis do fator habitat. Assim em Rodentia, estas três categorias baseadas na fisionomia da vegetação e colocadas aqui como regime seletivo não tem efeito sobre a evolução da encefalização como teria para outros grupos de mamíferos (HARVEY ET AL 1981). Mace et al (1981) testou se o tamanho relativo do encéfalo diferiria sistematicamente entre famílias de roedores, insectívoros e lagomorfos em relação tipos de vegetação, dieta, zonação e atividade temporal. Nos podemos considerar que foi o primeiro trabalho comparativo com roedores em que foi colocada a questão do tipo de habitat classificado a partir de tipos de bioma: florestas e campos abertos. Ele observou que as espécies de habitat de floresta diferem apresentando encéfalos relativamente maiores que as espécies de habitat aberto, mas seu resultado levou em consideração as relações filogenéticas entre as espécies, similarmente nossos dados brutos de QE demonstraram valores maiores para as espécies de floresta, mas nossos dados livre de filogenia mostraram a ausência de diferenças entre espécies de floresta, ambiente misto e área aberta, demonstrando que o efeito da filogenia teria um peso sobre a diferença detectada por Mace et al (1981), no entanto este resultado não invalida o que Mace et al (1981) propôs que as florestas são ambientes fisicamente mais diversificados do que as pastagens e são utilizadas por espécies residentes que se movem em três dimensões (BERNARD \& NURTON 1993), pois a depender do tamanho corporal do animal e do modo como ele usa o ambiente (estilo de vida), a fisionomia terá algum efeito sobre da evolução da encefalização na espécie principalmente nas demandas cognitivas relacionadas ao uso do espacial do habitat (BUDEAU \& VERTS 1986; SHUMWAY 2008) 
que também incluiria a relação com outras espécies da comunidade, através da competição e especialização de nichos, na qual espécies submetidas à ambiente de grande competição apresentariam maior encefalização (MACE \& EISENBERG 1982).

\section{Uso do habitat}

No fator uso do hábitat ou estilos de vida, quando avaliados os dados brutos, as espécies de roedores com hábito arborícola se destacam com valores médios maiores que espécies semifossoriais que foi maior que as espécies terrestre que foi maior que as espécies semi-aquáticas que foi maior que as espécies fossoriais e que foi maior que a espécies subterrânea. Assim quando a filogenia dá estruturação aos dados, ela dá peso as espécies que descendem de um ancestral com maior encefalização, como o do clado sciuromorpha que foi o grupo com maior encefalização já na sua base ancestral e com maior valor médio do QE (conforme nossos dados anteriormente apresentados). Além disso, as espécies deste clado são em sua maioria espécies arborícolas de floresta e outra parte são terrestre e semi-fossoriais que também apresentam valores medios mais altos. Este resultado corrobora o apresentado por Mace et al (1981) com Rodentia, Lagomorpha e Insetívora, na qual houve diferença entre a encefalização das arborícolas em relação as terrestres, mas sem discriminar mais categorias, pois a categoria terrestre incluia desde animais fossoriais a subterrâneos portanto sendo pouco refinado. Ainda na linha de estudos com roedores, Monadjem (1998) com roedores Myomorfos tambem detectou diferença para as espécies de hábito semi-arborícola, assim com no estudo de Bernard \& Nurton (1993) com espécies de roedores Hystricomorpha, Myomorpha e Sciuromorpha africanos. Quando testados os contrastes filogenéticos do QE das espécies de roedores entre os seis niveis do fator uso do hábitat, foi observada que as espécies semi-fossoriais diferem das semi-aquáticas 
e subterrâneas e estas diferem das terrestres. Não foi encontrada diferença entre fossoriais, subterrâneas, semi-aquáticas e arborícolas. Estes dados sugerem que sem o efeito da filogenia, a encefalização das espécies arborícolas não apresentam valores maiores que as espécies terrestres e semi-fossoriais enquanto que as espécies subterraneas tem encefalização significativamente baixa demonstrando uma dependência da estruturação da filogenia. A categoria semi-fossorial foi uma inovação neste nosso estudo comparativo já que não havia sido utilizado antes em outros estudos (MACE ET AL 1981, BernARD \& NuRTON 1993; MONADJEM 1998), pois a conceituação das espécies animais que vivem sob a superficie terrestre não é concenssual (BEGALL ET AL 2007), os animais subterrâneos podem ser caracterizado com adaptações a vida estritamente sob a superficies terrestre, realizando todas as suas necessidades fisiologicas e reprodutivas ali; as espécies fossoriais são em parte subterraneas mais vão a superficie em algum momento de sua atividade. Já as espécies semi-fossoriais, ao contrário das espécies fossoriais e subterrâneas não apresentam morfologia relacionada à atividades de escavações de túneis, como o corpo robusto e cilíndrico, patas curtas e fortes com garras desenvolvidas, orelhas reduzidas e olhos relativamente pequenos, no entanto estas espécies escavam seus proprio túneis em solos facilmente desagregados e apresentam um hábito terrestre, utilizando a superficie na busca por alimentos e parceiros reprodutivos, por essas condições, o hábito semi-fossorial reune as demandas cognitivas e sensoriais dos dois mundos: epigeo e hipogeo favorecendo a evolução da encefalização. Por outro lado, a vida subterranea é energeticamente custosa e sensorialmente limitada (BUFFENSTEIN 2000; BEGALL ET AL 2007), portanto com uma demanda conflitante entre a manutenção de um encéfalo maior, baixa demanda de informação sensorial e o custo da intensa atividade escavadora poderia resultar num controle para a encefalização reduzida. Outro ponto a ser observado é que espécies fossoriais e subterrâneas podem apresentar maior camada de tecido 
adiposos sob a pele e esta variável compõem a massa total do indivíduo, influenciado no quociente de encefalização que por ser uma razão, tenderá levar a uma redução do QE, por isso como alguns estudos levantaram, os depósitos de gordura podem ter um peso sofre o tamanho do encéfalo (NAVARRETE ET 2012).

\section{Tipo de dieta}

No fator tipo de dieta, os valores médios do QE bruto foram maiores nas espécies de dieta omnívora seguidos por dieta herbivoria rica que foi maior que a herbivoria pobre que foi maior que dieta animal e que foi maior que de dieta herbivoria generealista. Quando retirado o efeito da filogenia foi detectada que as espécies omnívoras apresentam maior encefalização que as espécies de dieta herbívora pobre e generalista, já as espécies de dieta herbívoras ricas apresentam encefalização maior que as espécies de dieta herbivora pobre e generalista. A dieta herbivora rica neste estudo inclui as frutas, as sementes e os tubérculos ricos em carboidratos. Este resultado reforça os dados obtidos em estudos anteriores com roedores, lagomorfos e insetívoros (Mace et al 1981) apenas com roedores do clado Myomorpha (MANN ET 1988; Monadjem 1998), com primatas das familias Cebidae, Lemuridae, Cercopithecidae e Pongidae (Clutton-Brock \& HaRvey 1980) e também em quirópteros (EisenBerg \& Wilson 1978) que tem demonstrado que espécies com dieta frugívora (rica em energia) apresentam encefalização maior que espécies de dieta folívora (pobre em energia) no entanto estes trabalhos não excluiram o efeito da filogenia dos seus dados, ao contrário dos nossos resultados que foram avaliados sem o efeito da filogenia assim como no estudo com primatas Lemuridae (MACLEAN ET AL 2009) que também detectou diferença entre espécies frugivoras e folivoras quanto a encefalização. Sendo assim o resultado reforça a importância de um dieta energeticamente rica para a manutenção de 
um encéfalo maior, apesar de que a dieta carnivora não ter se mostrado relevante em Rodentia, apesar da ocorrência das espécies do gênero Onychomys que são carnivoras e predadores de outro roedores (MANN \& TOWE 2003). Além disso considerando o encéfalo como um tecido energeticamente caro, conforme a hipótese do tecido caro de Aiello \& Wheeler (1995), no balanço energético frente a outros tecidos igualmente caros como o trato digestório, uma dieta rica em energia e de fácil digestibilidade poderia favorecer uma diminuição no trato digestivo resultando numa sobra de energia que pudesse ser aproveitada no funcionamento do encéfalo maior. Outra demanda importante com a diferença das dietas frugivoras e folivora seria a necessidade de localização espacial dos frutos no ambiente, já que a sua distribuição espacial ao acaso e imprevisível temporalmente dos frutos seria um desafio cognitivo para as espécies frugívoras impondo uma pressão seletiva para encéfalos maiores, principalmente para primatas como colocado no estudo de que propõe a hipótese da estrategia de forrageamento (MARTIN 1984), mas acreditamos que a dieta frugívora em Rodentia estaja mais relacionada a hipótese do tecido caro do que a da estratégia de forrageamento, pois os frutos se constituem um recurso mais limitado para animais de porte médio e grande do que de porte pequeno como a maioria dos roedores. Também a omnivoria em Rodentia se mostrou, assim como em Primata, um tipo de dieta importante para evolução de encéfalos maiores, poderiamos supor que animais omnívoros poderiam ocupar mais nichos a ponto de se tornarem mais generalista tendo que lidar com as mais diversos situações que demandassem a resolução de problemas na busca por alimentos variados (AlLMAN ET AL 1993). Assim a frugivoria e omnivoria são dois tipos de dieta que favorecem a evolução da encefalização em Rodentia. 


\section{Atividade temporal}

No fator atividade temporal, as espécies de roedores de atividade diurna apresentaram os maiores valores médios do QE bruto que as espécies de atividade noturna que foram maiores que as espécies de atividade quetameral. Assim quando a filogenia dá estruturação aos dados de atividade temporal, ela dá peso as espécies que já descendem de um ancestral com maior encefalização e que tenha atividade diurna, como o caso do clado sciuromorpha que é em sua grande maioria de atividade diurna e foi o grupo com maior encefalização desde a sua base ancestral e com maior valor médio do QE por clado. Este resultado é oposto ao que foi observado por Mace et al (1981) com roedores, lagomorfos e insetívoros no qual foi detectada que as espécies noturnas apresentam encéfalos maiores que as espécies diurnas. Quando retirado o efeito da filogenia observamos, que as espécies de atividade noturna apresentaram encefalização maior que as espécies de diurna e quetameral, inverso com relação aos nosso resultados com efeito da filogenia, mas semelhante ao estudo de Mace et al (1981) sem o efeito da filogenia, em vista disso, nosso resultado acompanhou a expectativa da previsão. A análise da questão da atividade temperal em Rodentia havia sido avaliada apenas no trabalho de Mace et al (1981), enquanto que em outros grupos de Mammalia foi retomado na década de 90, quando Barton (1996) testou a pergunta com relação aos primatas, sem incluir espécies quetamerais, a ordem Primates tem atividade temporal diurna e como regra seria esperado que a encefalização estivesse associado com a atividade diurna a necessidade associada a parte sensorial da visão, o que foi atestado por Barton (1996), mas só recentemente MacLean et al (2009) fez um estudo com primatas da família lemuridae incluindo espécies quetamerais e detectou que esta categoria apresentou encefalização maior que espécies diurnas e noturnas, ele sugeriu que a atividade quetameral levaria uma flexibilidade cognitiva o que demandaria mais encefalização (MACLEAN 
ET AL 2009). Por outro lado, estudos com o tamanho de áreas específicas do córtex sensorial indicaram que as diferenças no tamanho destas áreas tem relação consitente com o estilo de vida sensorial e a morfologia das espécies, como entre espécies diurnas e noturnas e terrestres e arborícolas (CAMPI \& KUBRITZER 2010), Assim a análise do encéfalo como um todo pode ser complementada quando outras áreas de funções sensoriais específicas são também avaliadas.

\section{Sociabilidade}

No fator tipo de sociabilidade, as espécies semi-sociais apresentaram os valores médios do QE maiores que as espécies solitárias, que foram maiores que as espécies sociais. Quando avaliamos os dados sem efeito da filogenia não foi encontrada diferença significativa entre as categorias propostas. Esse resultado foi similar ao estudo com Primatas da família Lemuridae (MACLEAN ET AL 2009) e contrariou nossa previsão sobre a sociabilidade, já que consideramos esse fator um dos principais promotores de demandas cognitivas e consequentemente aumento do encéfalo, essa hipótese seria cunhada como hipótese do cérebro social. As evidências para a hipótese do cérebro social, surgiu a partir de um grande número de observações e estudos experimentais que documentaram as habilidades excepcionais de primatas para resolver problemas sociais (para revisões, ver Byrne \& Whiten, 1988; TOMASEllo \& CALl, 1997). Primatas, especialmente os chimpanzés, solucionaram problemas que exigem complexas formas de cognição na vida social, como a imitação (HORNER E WHITEN, 2005), a teoria da mente (HARE ET AL., 2000, 2001), aprendizagem social (BONNIE ET AL., 2007), cooperação (MELIS ET AL., 2006) e a trapaça (BYRNE \& CORP 2004). Assim devido a complexidade das relações sociais presente nos primatas antropóides assumidas na hipótese do cérebro social, nosso resultado com a ordem Rodentia demonstra que o nivel da sociabilidade presente no grupo não é tão complexa a ponto de se criar 
uma pressão seletiva sobre a encefalização no grupo. A ordem Rodentia apresenta ao longo do seu continuum social, a única espécie de mamífero eussocial, o Bathyrgideo Heterocephalus glaber que é subterraneo, mas apresenta encefalização abaixo do esperado, sendo assim para esta espécie seria esperado ter encefalização acima do esperado, mas a vida subterrânea pode ter sidoa demanda conflitante a ponto de ser contigência importante ao aumento do encéfalo.

\section{Estágio de desenvolvimento do neonato}

No fator estágio de desenvolvimento do neonato, as espécies de roedores altriciais apresentaram valores médios do QE bruto maiores que as espécies roedores precociais. Em Rodentia, as espécies que apresentam estágio de desenvolvimento do neonato do tipo altricial são a maioria em diversidade de espécies enquanto que as espécies precociais são restritas ao clado dos hystricomorpha com alguns representantes nos clados Myomorpha e Castorimorpha, além disso, os hytricomopha apresentam encefalização média no mesmo nível dos outros clados, contribuindo para abaixar a encefalização das espécies precociais. Quando avaliados sem o efeito da filogenia, os dados demonstram que as espécies altriciais apresentam encefalização maior que as espécies precociais, esse resultado concorda com a previsão deste trabalho. Assim os roedores quando avaliados de modo isolado dos outros mamíferos apresentam aumento da encefalização nos adultos das espécies altriciais em relação as espécies precociais que apresentam uma variação menor no QE. As espécies altriciais que possuem o tempo de gestação menor e comportam uma variação maior do QE quando adultos. A ordem Rodentia se enquadra na hipótese da energia maternal do Martin (1996) que estabelece que a energia materna seja um fator limitante da capacidade energética para o desenvolvimento do encéfalo fetal, assim as espécies altriciais (neonato pouco desenvolvido) neonatos apresentam encéfalos relativamente menores que sofrem um crescimento mais acelerado e que quando adultos atinge encefalização 
superior em relação às espécies precociais (neonato muito desenvolvido) que após o nascimento apresenta um crescimento lento (HARVEY \& KREBS 1990; AbOITIZ 1996; WeISBECKER \& GosWAMI 2010). 


\section{REFERÊNCIAS BIBLIOGRÁFICAS}

ABOITIZ, F. Does bigger mean better? Evolutionary determinants brain size and structure. Brain Behavior and Evolution. 47: pp. 225-245, 1996.

ADKINS, R.; GELKE, E.; ROWE, D.; HONEYCUTT, R.; Molecular phylogeny and divergence time estimates for major rodent groups: evidence from multiple genes. Mol Biol Evol. 18: pp. 777-791, 2001.

AIELLO, L.C. \& WHEELER, P. The expensive-tissue hypothesis: the brain and the digestive system in human and primate evolution. Curr. Anthropol. 36: pp. 199-221, 1995.

ALEXANDER. L. F.; RIDDLE, B. R. Phylogenetics of the new world rodent family Heteromyidae. Journal of Mammalogy, 86(2): pp. 366-379, 2005.

ALLMAN, J.; MCLAUGHLIN, T.; HAKEEM, A. Brain weight and life-span in primate species.Proc. Natl. Acad. Sci. USA 90, pp. 118-122, 1993.

BAUCHOT, R. L'encéphalisation chez les Carnivores et les Artiodactyles. Mammalia. 49(4): pp. 559-572.

BLANGA-KANFI, S.; MIRANDA, H.; PENN, O.; PUPKO, T.; DEBRY, R. W.; HUCHON, D.; Rodent phylogeny revised: analysis of six nuclear genes from all major rodent clades. BMC Evol Biol. 9:71. 2009.

BARRICKMAN, N. L.; BASTIAN, M. L.; ISLER, K.;; VAN SCHAIK, C. P. Life history costs and benefits of encephalization: a comparative test using data from long-term studies of primates in the wild. J. Hum. Evol. 54, 568-590, 2008.

BARTON, R.A. Neocortex size and behavioural ecology in primates. Proc. R. Soc. Lond. B. 263, pp. 173-177, 1996. 
BARTON, R. A..; HARVEY, P. H. Mosaic evolution of brain structure in mammals. Nature 405, pp. 1055-1058, 2000.

BAUCHOT, R..; STEPHAN, H.. Données nouvelles sur l'encéphalisation des insectivores et des prosimiens. Mammalia 30, pp. 160-196, 1966.

BEGALL, S.; BURDA, H.; SCHLEICH, C. E. Subterranean Rodents: News from Underground.In: BEGALL, S.; BURDA, H.; SCHLEICH, C. E. (Orgs.). Subterranean Rodents: News from Underground Berlin Heidelberg: Springer-Verlag. 3-9, 2007.

BENTON, M. J. Vertebrate Paleontology. Third edition. Blackwell publishing, 2005.

BERNARD, R. T. F., NURTON, J. Ecological correlates of relative brain size and some south African rodents. S. Afr. J. Zool. 28(2). pp. 95-98, 1993.

BININDA-EMONDS, O. R.; CARDILLO, M.; JONES, K. E.; MACPHEE, R. D.; BECK, R. M.; GRENYER, R. The delayed rise of present-day mammals. Nature 446: pp. 507-512. 2007.

BLOMBERG, S. P., GARLAND JR., T. \& IVES, A. R. Testing for phylogenetic signal in comparative data: behavioral traits are more labile. Evolution, 57(4), 717-745, 2003.

BODDY, A. M.; MCGOWEN, M. R.; SHERWOOD, C. C.; GROSSMAN, L. I.; GOODMAN, M.; WILDMAN, D. E. Comparative analysis of encephalization in mammals reveals relaxed constraints on anthropoid primate and cetacean brain scaling. Journal of evolutionary biology. 25 (2012) 981-994, 2012.

BONNIE, K.E., HORNER, V., WHITEN, A., DE WAAL, F.B.M., 2007. Spread of arbitrary conventions among chimpanzees: A controlled experiment. Proc. R. Soc. Lond. B. 274: pp. 367-372. 2007. 
BUDEAU, D. A.; VERTS, B. J. Relative brain size and structural complexity of habitats of Chipmunks. J. Mammal. 67: pp. 579-581, 1986.

BUFFENSTEIN, R. Ecophysiological responses of subterranean rodentsto underground habitas. LACEY, E.; PATTON, J. L.; CAMERON, G. N. (Eds). Life Underground: the biology of subterranean rodents. The university of Chicago press, Chicago, 2000.

BUSH, E. C.; ALLMAN, J. M. The scaling of frontal Cortex in primates and carnivores. Proc Natl Acad Sci USA. 101: pp. 3962-3966, 2004.

BUTLER, A. B.; HODOS, W. Comparative vertebrate neuroanatomy: evolution and adaptation. Second Edition John Wiley \& Sons, Inc., Hoboken, New Jersey. 2005.

BYRNE, R. W.; WHITEN, A. Machiavellian Intelligence: Social Expertise and the Evolution of Intellect in Monkeys, Apes and Humans. New York, NY: Oxford University Press, 1988.

BYRNE, R. W.; CORP, N. Neocortex size predicts deception rate in primates. Proc. R. Soc. Lond. B 271: pp. 1693-1699, 2004.

CARLETON, M. D.; MUSSER, G. G. Muroid rodents. In: ANDERSON, S., JONES, J.K., JR.JR. (Eds.), Orders and Families of Recent Mammals of the World. John Wiley and Sons, New York, pp. 289-379, 1984.

CARLETON M.; MUSSER, G. Order Rodentia, Volume 2 of Mammal species of the world: A taxonomic and geographic reference. 3rd ed. Baltimore: Johns Hopkins University Press, 2005.

CHANGIZI, M. A. Relationship between number of muscles, behavioral repertoire size, and encephalization in mammals. J. Theor. Biol. 220, 157-168, 2003. 
CHURAKOV, G., SADASIVUNI, M. K., ROSENBLOOM, K. R., HUCHON, D., BROSIUS, J., SCHMITZ, J. Rodent Evolution: Back to the Root. Mol. Biol. Evol. 27(6): pp. 1315-1326, 2010.

CLANCY, B., DARLINGTON, R. B. AND FINLAY, B. L. Translating developmental time across mammalian species. Neuroscience. 105: pp. 7-17, 2001.

CLUTTON-BROCK, T. H.; HARVEY, P. H. Primates, brains and ecology. J. Zool., Lond. 190: pp. 309-324, 1980.

COMPOINT-MONMIGNAUT, C. L'encephalisation chez les roungeur. C.r. hebd. Séanc. Acad. Sci. 277: pp. 861-863, 1973.

CRILE, G.; QUIRING, D. P. A. 1940. A record of the body weight and certain organ and gland weights of 3960 mammals. Ohio J. Sci. 40, 5. 219-259.

D. ELIA, G. 2003. Phylogenetics of sigmodontinae (Rodentia, Muroi- dea, Cricetidae), with special reference to the akodont group, and with additional comments on historical biogeography. Cladistics 19: pp. 307-323, 2003.

DEANER, R. O.; ISLER, K.; BURKART, J.; VAN SCHAIK, C. P. Overall brain size, and not encephalization quotient, best predicts cognitive ability across non human primates. Brain Behav. Evol. 70: pp. 115-124, 2007.

DUNBAR, R. I.; SHULTZ, S. Understanding primate brain evolution. Phil. Trans. R. Soc. B 362: pp. 649-658, 2007.

DUNBAR, R. I. The social brain hypothesis. Evol. Anthropol. 6: pp. 178-190, 1998.

EISENBERG, J. F, WILSON DE Relative brain size and feeding strategies in the chiroptera. Evolution. 32: pp. 740-751, 1978. 
EISENBERG J: The mammalian radiations: analysis of trends in evolution, adaptation, and behaviour. Chicago: The University of Chicago Press; 1981.

FABRE, P. H., HAUTIER, L., DIMITROV, D., DOUZERY, E. J. P. A glimpse on the pattern of rodent diversification: a phylogenetic approach. BMC Evo Biol. 12:88, 2012.

FAN, Z.; LIU, S.; LIU, Y.; ZENG, B.; ZHANG, X.; GUO, C.; YUE, B. Molecular phylogeny and taxonomic reconsideration of the subfamily Zapodinae (Rodentia: Dipodidae), with an emphasis on Chinese species. Molecular Phylogenetics and Evolution. 51: pp. 447-453, 2009.

FELSENSTEIN, J. Phylogenies and the comparative method. Am. Nat. 125: pp. 1-15, 1985.

FINARELLI, J. A.; FLYNN, J. J. Brain-size evolution and sociality in Carnivora. Proc. Natl Acad. Sci. USA. 106: 9345-9349, 2009.

FINLAY, B. L.; DARLINGTON, R. B. Linked regularities in the development and evolution of mammalian brains. Science. 268: pp. 1578-1584, 1995.

GAlEWSKI, T.; MAUfFreY, J. F.; LEITE, Y. L.; PATTON, J. L.; DOUZERY, E. J. P.; Ecomorphological diversification among South American spiny rats (Rodentia; Echimyidae): a phylogenetic and chronological approach. Mol Phylogenet Evol, 34:601-615, 2005.

GALEWSKI, T.; TILAK, M. K.; SANCHEZ, S.; CHEVRET, P.; PARADIS, E.; DOUZERY, E. J.; The evolutionary radiation of Arvicolinae rodents (voles and lemmings): relative contribution of nuclear and mitochondrial DNA phylogenies. BMC Evol Biol. 6: 80. 2006.

GARLAND, T. JR, HARVEY, P.H. \& IVES, A.R. Procedures for the analysis of comparative data using phylogenetically independent contrasts. Syst. Biol. 41: pp. 18-32. 1992. 
GEFFEN, E.; ROWE, K. C.; YOM-TOV, Y. Reproductive Rates in Australian Rodents Are Related to Phylogeny. PLOS.one 6(4): pp. 1-9, 2011.

GIBSON, K. R. Cognition, brain size and the extraction of embedded food resources. In ELSE, J.; LEE, P.C. (eds), Primate Ontogeny, Cognition and Social Behaviour, pp 93-104. Cambridge: Cambridge University Press, 1986.

GITTLEMAN, J. H. Carnivore brain size, behavioural ecology and phylogeny. J Mammal. 67: pp. 23-36, 1986.

GLENDENNING, K. K.; MASTERTON, R. B. 1998. Comparative morphometric of mammalian central auditory systems: variation in nuclei and form of the ascending system. Brain Behav. Evol., v 51, 59-89.

GODFREY-SMITH, P. Complexity and the function of mind in nature. Cambridge: Cambridge University press, 1996.

FOX, J. H.; WILCZYNSKI, W. Allometry of major CNS divisions: towards a reevalution of somatic brain-body scaling. Brain Behav. Evol., 28: pp.157-169, 1986.

HAFNER, M. S.; HAFNER, J. C. Brain size, adaptation and heterochrony in geomyoid rodents. Evolution, 38(5): pp. 1088-1984, 1984.

HAFNER, M. S.; HAFNER, D. J.; DEMASTES, J. W.; HASTY, G. L.; LIGHT, J. E.; SPRADLING, T. A. Evolutionary Relationships of Pocket Gophers of the Genus Pappogeomys (Rodentia: Geomyidae). Journal of Mammalogy, 90(1): pp. 47-56, 2009.

HARE, B.; CALL, J.; AGNETTA, B.; TOMASELLO, M. Chimpanzees know what conspecifics do and do not see. Anim. Behav. 59: pp. 771-785, 2000. 
HARE, B.; CALL, J.; TOMASELlO, M. Do chimpanzees know what conspecifics know? Anim. Behav. 61: pp. 139-151, 2001.

HARVEY, P. H.; KREBS, J. R. Comparing brains. Science. 249: pp. 150-156, 1990.

HARVEY, P. H.; CLUTTON-BROCK, T. H.; MACE, G. M. Brain size and ecology in small mammals and primates. Proc. Natl. Acad. Sci. USA. 77 (7): pp. 4387-4389, 1980.

HEALY, S. D.; ROWE, C. A critique of comparative studies of brain size. Proc. R. Soc. B. 274 : pp. 453-464, 2007.

HERRON, M.; CASTOE, T.; PARKINSON, C. Sciurid phylogeny and the paraphyly of Holarctic ground squirrels (Spermophilus). Mol Phylogenet Evol. 31: pp.1015-1030, 2004.

HERSHKOVITZ, P. The recent mammals of the Neotropical region: a zoogeographic and ecological review. In: KEAST, A. F.; ERK, F. C.; GLASS, B. (Eds.), Evolution, Mammals, and Southern Continents. State University of New York Press, Albany, pp. 311-431, 1972.

HOFFMANN, R. S., C. G. ANDERSON, R. W. THORINGTON, JR., AND L. R. HEANEY. Family Sciuridae. In Mammal species of the world, ed. WILSON, D. E.; REEDER, D. M. pp. 419 -465. Washington, DC: Smithsonian Institution Press. 1993.

HOFMAN, M. A. A two-component Theory of encephalization in Mammals. J. theor. Biol. 99: pp. 571-584, 1982.

HOFMAN, M. A. Encephalization and evolution of longevity in mammals. J. Evol. Biol. 6: pp. 209-227, 1993.

HONEYCUTT, R. L.; FRABOTTA, L. J.; ROWE, D. L. Rodent Evolution, Phylogenetics, and Biogeography: Wolff, J. O., Sherman, P. W (eds). Rodent Societies: An Ecological \& Evolutionary perspective. The University of Chicago Press. Chicago and London, 2007. 
HOPKINS, S. S. B. Phylogeny and evolutionary history of the Aplodontoidea (Mammalia: Rodentia). Zoological Journal of the Linnean Society, 153: pp. 769-838, 2008.

HORNER, V.; WHITEN, A. Causal knowledge and imitation/emulation switching in chimpanzees (Pan troglodytes) and children (Homo sapiens). Anim. Cogn. 8: pp. 164-181, 2005.

HUCHON, D; DOUZERY, E. From the Old World to the New World: a molecular chronicle of the phylogeny and biogeography of hystricognath rodents. Mol Phylogenet Evol, 20: pp. 239$251,2001$.

HUCHON, D.; CATZEFLIS, F. M.; P. DOUZERY . E. J. Variance of molecular datings, evolution of rodents and the phylogenetic affinities between Ctenodactylidae and Hystricognathi. Proc. R. Soc. Lond. B 267: pp. 393-402, 2000.

HUCHON, D.; MADSEN, O.; SIBBALD, M. J.; AMENT, K.; STANHOPE, M. J.; CATZEfIIS, F.; DE JONG, W. W.; DOUZERY, E. J. Rodent phylogeny and a timescale for the evolution of Glires: evidence from an extensive taxon sampling using three nuclear genes. Mol Biol Evol. 19: pp. 1053-1065. 2002.

HUCHON, D.; CHEVRET, P.; JORDAN, U.; KILPATRICK, C. Multiple molecular evidences for a living mammalian fossil. Proc Natl Acad Sci USA. 104: pp.7495-7499, 2007.

HRDLICKA, A. Brain weight in vertebrates. Smithsonian Inst Misc. Coll. 48: pp 89-112. 1905.

GRZIMEK'S ANIMAL LIFE ENCYCLOPEDIA, 2nd edition. Volumes 12-16, Mammals $I-V$, edited by HUTCHINS, M.; KLEIMAN, D. G.; GEIST, V.; MCDADE, M. C. Farmington Hills, MI: Gale Group, 2003.

GROVE, M. Orbital dynamics, environmental heterogeneity, and the evolution of the human brain. Intelligence. 40: PP. 404-418, 2012. 
ITO, M., JIANG, W., SATO, J. J., ZHEN, Q., JIAO, W., GOTO, K., SATO, H., ISHIWATA, K., OKU, Y., CHAI, J., KAMIYA, H. Molecular Phylogeny of the Subfamily Gerbillinae (Muridae, Rodentia) with Emphasis on Species Living in the Xinjiang-Uygur Autonomous Region of China and Based on the Mitochondrial Cytochrome b and Cytochrome c Oxidase Subunit II Genes. Zoological Science. 27: pp. 269-278, 2010.

JACOBS, L.F.; SPENCER, W.D. Natural space-use patterns and hippocampal size in kangaroo rats. Brain Behavioral Evolution, 44: pp.125-132, 1994.

JANSA, S.; WEKSLER, M. Phylogeny of muroid rodents: relationships within and among major lineages as determined by IRBP gene sequences. Mol Phylogenet Evol. 31: pp. 256-276, 2004.

JERISON, H. J.. Evolution of the Brain and Intelligence.. New York, NY: Academic Press, 482 pp, 1973.

JERISON, H.J. Animal intelligence as encephalization. Philos. Trans. R. Soc. Lond. B Biol. Sci. 308: pp. 21-35, 1985.

KRUBITZER, L.; KAAS, J. The evolution of the neocortex in mammals: how is phenotypic diversity generated? Curr. Opin. Neurobiol. 15, pp. 444-453, 2005.

KRUCKENHAUSER, L.; PINSKER, W.; HARING, E.; ARNOLD, W. Marmot phylogeny revisited: molecular evidence for a diphyletic origin of sociality. J. Zool. Syst. Evol. Research. 37: pp. 49-56, 1998.

KRUSKA, D. How fast can total brain size change in mammals. J Hirnforsch. 28: pp. 59-70, 1987.

KRUSKA, D. C. T.; STEFFEN, K. Encephalization of Bathyergidae and comparison of brain structure volumes between the Zambian mole-rat Fukomys anselli and the giant mole-rat Fukomys mechowii. Mammalian Biology. 74: pp. 298-307, 2009. 
KUMMER, H.; DASTON, L.; GIGERENZER, G.; SILK, J. The social intelligence hypothesis. In: WEINGART, P., MITCHELL, S.D., RICHERSON, P.J., MAASEN, S. (Eds.), Human By Nature: Between Biology and the Social Sciences. Lawrence Erlbaum Associates, Mahwah, NJ, pp. 157-179, 1997.

LAPOINTE, F.; BARON, G.; LEGENDRE, P. Encephalization, Adaptation and Evolution of Chiroptera: A Statistical Analysis with Further Evidence for Bat Monophyly. Brain, Behaviour and Evolution. 54: pp. 1119-1126, 1999.

LEFEBVRE, L.; READER, S. M.; BOIRE, D. The evolution of encephalization. KAAS, J. H (ed). Evolution of Nervous systems: A comprehensive reference. Volume 1. Academic Press; 1 edition, 2007.

LEFEBVRE, L.; SOL, D. Brains, Lifestyles and Cognition: Are There General Trends? Brain Behav. Evol. 72: pp. 135-144, 2008.

LEFEBVRE, L.; READER, S. M.; SOL, D. Brains, innovations and evolution in birds and primates. Brain Behav. Evol. 63: pp. 233-246, 2004.

LUCKETT, W.; HARTENBERGER, J. L. Monophyly or polyphyly of the order Rodentia: possible conflict between morphological and molecular interpretations. J Mammal Evol, 1:127$147,1993$.

MADDISON, W.P.; MADDISON, D. R. Mesquite: a modular system for evolutionary analysis. Version 2.74. Available at: http://mesquiteproject.org. 2009.

MACE, G. M.; HARVEY, P. H.; CLUTTON-BROCK, T. H. Brain size and ecology in small mammals. J. Zool. 193: pp. 333-354, 1981. 
MACE, G. M.; EISENBERG, J. F. Competition, niche specialization and the evolution of brain size in the genus Peromyscus. Biol. J. Linnean Soc. 17: pp. 243-257, 1982.

MACLEAN, E. L.; BARRICKMAN, N. L.; JOHNSON, E. M.; WALL, C. E. Sociality, ecology, and relative brain size in lemurs. Journal of Human Evolution. pp. 1-8, 2009.

MANN, M. D.; GLICKMAN, S. E.; TOWE, A. L. Brain/body relations among myomorph rodents. Brain Behav Evol. 31: pp.111-124, 1988.

MARES, M. A.; OJEDA, R. A. Patterns of diversity and adaptation in South American hystricognath rodents. In: Mares, M.A., Genoways, H.H. (Eds.), Mammalian Biology in South America. Pymatuning Laboratory of Ecology, University of Pittsburgh, Pittsburgh, pp. 393-432, 1982.

MARINO, L. A comparison of encephalization between odontocete cetaceans and anthropoid primates. Brain Behav. Evol. 51: pp. 230-238, 1998.

MARTIN, R. D. Relative brain size and basal metabolic rate in terrestrial vertebrates. Nature 293: pp. 57-60, 1981.

MARTIN, R. D. 1984. Body size, brain size and feeding strategies. In: Food, Acquisition and Processing in Primates. CHIVERS, D.J.; WOOD, B; BILSBOROUGH, A (eds), pp. 73-103. Plenum Press, New York.

MARTIN, R. D. Scaling of the mammalian brain: the maternal energy hypothesis. News Physiol. Sci. 11: pp. 149-156, 1996.

MCNAB, B. K.; EISENBERG, J. F. Brain size and its relation to the rate of metabolism in mammals. Am. Nat.133: pp. 157-167. 1989. 
MELIS, A. P.; HARE, B.; TOMASELLO, M. Chimpanzees recruit the best collaborators. Science. 311: pp. 1297-1300, 2006.

MILLER, J. R.; ENGSTROM, M. D. The Relationships of Major Lineages within Peromyscine Rodents: A Molecular Phylogenetic Hypothesis and Systematic Reappraisal. Journal of Mammalogy, 89(5): pp. 1279-1295, 2008.

MONADJEN, A. Relative brain size of some southern African myomorph rodents. S. Afr. J. Zool. V 33.n 1 47-49. 1998.

MONTGELARD, C.; FORTY, E.; ARNAL, V.; MATTHEE, C. A.; Suprafamilial relationships among Rodentia and the phylogenetic effect of removing fast-evolving nucleotides in mitochondrial, exon and intron fragments. BMC Evol Biol. 8:321, 2008.

MUSSER, G. G.; CARLETON, M. D. Family Muridae. In Mammal species of the world, ed. D. E. Wilson and D. M. Reeder, 501-755. Washington, DC: Smithsonian Institution Press, 1993.

NAVARRETE, A.; VAN SCHAIK, C. P.; ISLER, K. Energetics and the evolution of human brain size. Nature. 480: pp. 91-93, 2011.

NEDBAL, M. A.; HONEYCUTT, R. L.; SCHLITTER, D. A. Higher-level systematics of rodents (Mammalia, Rodentia): Evidence from the mitochondrial 12S rRNA gene. Journal of Mammalian Evolution. 3: pp. 201-237, 1996.

NOWAK, R. M. Walker's Mammals of the World, Vol. 2. The John Hopkins University Press, Baltimore and London, 1999.

NUNOME M.; YASUDA, S. P.; SATO, J. J.; VOGEL, P.; SUZUKI, H. Phylogenetic relationships and divergence times among dormice (Rodentia, Gliridae) based on three nuclear genes. Zool Scripta 36: pp. 537-546, 2007. 
PAGEL M. D.; HARVEY, P. H. Taxonomic differences in the scaling of brain on body weight among mammals. Science. 244: pp. 1589-1593,1989.

PAGEL, M. D. A method for the analysis of comparative data. J. Theor. Biol. 156: pp. 431-442, 1992.

PAGEL, M. Inferring the historical patterns of biological evolution. Nature 401, pp. 877-884, 1999.

PARADA, A.; PARDIÑAS, U. F. J.; SALAZAR-BRAVO, J.; D’ELIA, G.; PALMA, R. E. Dating an impressive Neotropical radiation: Molecular time estimates for the Sigmodontinae (Rodentia) provide insights into its historical biogeography. Molecular phylogenetics and Evolution. 66: pp. 960-968, 2013.

PARKER, S. T.; GIBSON K. R. Object manipulation, tool use and sensorimotor intelligence as feeding adaptations in great apes and Cebus monkeys. J Hum Evol. 6: pp. 623-641, 1977.

PECNEROVÁ, P.; MARTINKOVÁ, N. Evolutionary history of tree squirrels (Rodentia, Sciurini) based on multilocus phylogeny reconstruction. Zoologica Scripta. 3: pp. 211-219. 2011.

PÉREZ-BARBERIA, F. J.; GORDON, I. J. Gregariousness increases brain size in ungulates. Oecologia 145: pp. 41-52, 2005.

PEREZ-BARBERIA F. J.; SHULTZ, S.; DUNBAR, R. I. M. Evidence for coevolution of sociality and relative brain size in three orders of mammals. Evolution. 61: pp. 2811-2821, 2007.

PILLERI, G. Vergleichend-anatomische untersuchungen am gehirn von Lophiomys, Tatera, Brachyuromys und Petromus (Mammalia, Rodentia). Rev. Suisse de Zool. T 67(29): pp. 373386, 1962. 
PIRLOT, P.; NEVO, E. Brain organization and evolution in subterranean mole rats. Z Zool Syst Evol-Forsch. 27: pp. 58-64, 1989.

PIRLOT, P.; BEE DE SPERONI, N. Encephalization and brain composition in South American rodents (Caviidae, Cricetidae, Dasyproctidae). Mammalia. 51(2): pp. 305-320, 1987.

POOLE, T. Social behaviour in mammals. New York, Chapman and Hall. 1985.

QUINN, G. P.; KEOUGH, M. J. Experimental Design and Data Analysis for biologists. Cambridge University press, 2002.

R Development Core Team 2008. R: A Language and Environment for Statistical Computing. R Foundation for Statistical Computing, Vienna, Austria. ISBN: 3-900051-07-0. http://www. Rproject.org.

RADINSKY, L. Evolution of brain size in carnivores and ungulates. Am.Nat. 112: pp. 815-831, 1978.

READ, A. F., NEE, S. 1995. Inference from Binary Comparative Data. J. theor. Biol. 173, 99108.

REID, N.; DEMBOSKI, J. R.; SULLIVAN, J. Phylogeny Estimation of the Radiation of Western North American Chipmunks (Tamias) in the Face of Introgression Using Reproductive Protein Genes. Syst Biol. 61(1): pp. 44-62. 2012.

RIBEIRO, M. F. S. Encéfalos de espécies de roedores Trinomys de diferentes habitats e seus correlatos ecotológicos. Dissertação de mestrado. Instituto de Psicologia. Universidade de São Paulo, 2004: 
ROBOVSKY, J.; RICANKOVA, V.; ZRZAVY, J. Phylogeny of Arvicolinae (Mammalia, Cricetidae): utility of morphological and molecular data sets in a recently radiating clade. Zoologica scripta. 37(6): pp. 571-590, 2009.

SACHER, G. A., STAFFELDT. E. F. Relation of gestation time to brain weight for placental mammals: implications for theory of vertebrate growth. Am. Nat. 108: pp. 593-615, 1974.

SHEA, B. T. Reproductive strategies, body size, and Encephalization in Primates Evolution. International Journal of Primatology, 8 (2), 1987.

SHERRY, D. F. Neuroecology. Ann Rev Psychol. 57: pp. 167-197. 2006.

SHETtLEWORTH, S. J. Cognition, evolution, and behavior, 2nd ed. Oxford: Oxford University press, 2010.

SCHOENEMANN, P. T. Brain size scaling and body composition in mammals. Brain Behav. Evol.63: pp. 47-60, 2004.

SHUMWAY, C. Habitat complexity, brain, and behavior. Brain Behav Evol. 72: pp. 123-134, 2008.

SOBRERO, R.; MAY-COLLADO, L. J.; AGNARSSON, I.; HERNÁNDEZ, C. E. Expensive brains: "brainy" rodents have higher metabolic rate. Frontiers in Evolutionary Neuroscience. 3( 2): pp. 1-12, 2011.

STEPPAN, S.; ADKINS, R.; ANDERSON, J. Phylogeny and divergence-date estimates of rapid radiations in muroid rodents based on multiple nuclear genes. Syst Biol. 53: pp. 533-553, 2004 
STEPPAN, S.; STORZ, B.; HOFFMANN, R.; Nuclear DNA phylogeny of the squirrels (Mammalia: Rodentia) and the evolution of arboreality from c-myc and RAG1. Mol Phylogenet Evol, 30: pp. 703-719, 2004.

STEPPAN, S. J.; ADKINS, R. M.; SPINKS, P. Q.; HALE, C. Multigene phylogeny of the Old World mice, Murinae, reveals distinct geographic lineages and the declining utility of mitochondrial genes compared to nuclear genes. Mol Phylogenet Evol, 37: pp. 370-388, 2005

STRIEDTER, G. F. Principles of Brain Evolution. Sinauer Associates. 2005.

THORINGTON, R. W.; DARROW, K.; BETTS, A. D. K. Comparative myology of the forelimb of squirrels (Sciuridae). Journal of Morphology. 234: pp. 155-82, 1997.

TOMASEllO, M.; CALL, J. Primate Cognition. Oxford University Press, New York. 1997.

TOWE, A. L.; MANN, M. D. Brain size/body length relations among myomorph rodents. Brain Behav Evol. 39:pp. 17-23, 1992.

UPHAM, N. S.; PATTERSON, B. D. Diversification and biogeography of the Neotropical caviomorph lineage Octodontoidea (Rodentia: Hystricognathi). Molecular Phylogenetics and Evolution. 63: pp. 417-429, 2012.

VASSALlO, A. I.; ECHEVERRIA, A. I. Evolution of Brain Size in a Highly Diversifying Lineage of Subterranean Rodent Genus Ctenomys (Caviomorpha: Ctenomyidae). Brain, Behavior and Evolution. 73: pp.138-149, 2008.

VENIAMINOVA, N. A, VASSETZKY, N. S, KRAMEROV, D. A. B1 SINEs in different rodent families. Genomics. 89: pp. 678-686, 2007. 
VON BONIN, G. 1937. Brain-weight and body-weight of mammals. J. Gen. Psychol. 16, 373389.

WEISBECKER, V.; GOSWAMI A. Brain size, life history, and metabolism at the marsupial/placental dichotomy. Proc Natl Acad Sci USA. 107: 16216-21, 2010.

WORTHY, G.; HICKIE, J. Relative brain size in marine mammals. Am. Nat. 128: 445-459. 1986.

WILSON, D. E.; REEDER, D. M. Mammal Species of the World: A Taxonomic and Geographic Reference, 3rd Edn. Baltimore, MD:Johns Hopkins University Press. 2005.

ZHANG, Q., XIA, L., KIMURA, Y., SHENBROT, G., ZHANG, Z., GE, D., YANG, Q. Tracing the Origin and Diversification of Dipodoidea (Order: Rodentia): Evidence from Fossil Record and Molecular Phylogeny. Evol Biol. 40: 32-44, 2013.

$\underline{\text { Redigido de acordo com as diretrizes: }}$

ASSOCIAÇÃO BRASILEIRA DE NORMAS TÉCNICAS. NBR 6023: Informação e documentação: Referência -Elaboração; Rio de Janeiro, 2002.

. NBR 10520: Informação e documentação: citações em documentos - apresentação. Rio de Janeiro, 2002.

. NBR 6024: Informação e documentação - Numeração progressiva das seções de um documento escrito - Apresentação, Rio de Janeiro, 2003.

MALERBO, M. B. Referências e citações bibliográficas: Manual de orientação, Ribeirão Preto, PCARP - USP (Serviço de Biblioteca e documentação), 1996.

UNIVERSIDAdE DE SÃo PAUlO. Sistema Integrado de bibliotecas. Grupo DiTesis. In: FURANO, V.M. B. de O. (coord.). Diretrizes para apresentação de dissertações e teses da USP: documento eletrônico e impresso. São Paulo: SIBi-USP, 110p., 2004. 


\section{ANEXO}

Anexo I - Dados brutos referentes à variável de TFL - Tempo requerido para alcançar o fim do labirinto para as espécies T. yonenagae em todas os testes (T1-T18) no labirinto complexo.

\begin{tabular}{|c|c|c|c|c|c|c|c|c|c|c|c|c|c|c|c|c|c|c|c|c|}
\hline$\#$ & Tag & sexo & $\mathrm{T} 1$ & $\mathrm{~T} 2$ & T3 & $\mathrm{T} 4$ & T5 & T6 & T7 & T8 & T9 & $\mathrm{T} 10$ & T11 & T12 & T13 & T14 & T15 & T16 & T17 & T18 \\
\hline 1 & Y01 & $\mathrm{M}$ & 141 & 61 & 388 & 45 & 28 & 175 & 26 & 16 & 18 & 13 & 107 & 117 & 99 & 50 & 46 & 102 & 56 & 704 \\
\hline 2 & Y02 & $\mathrm{M}$ & 512 & 143 & 314 & 237 & 203 & 53 & 1444 & 184 & 65 & 89 & 241 & 497 & 26 & 30 & 103 & 24 & 44 & 89 \\
\hline 3 & Y04 & $\mathrm{M}$ & 1235 & 1100 & 38 & 30 & 1157 & 290 & 28 & 18 & 41 & 160 & 135 & 39 & 62 & 104 & 96 & 389 & 222 & 320 \\
\hline 4 & Y10 & $M$ & 1066 & 117 & 157 & 416 & 128 & 143 & 114 & 64 & 319 & 50 & 245 & 32 & 374 & 179 & 166 & 122 & 187 & 162 \\
\hline 5 & Y11 & $\mathrm{M}$ & 1135 & 94 & 334 & 158 & 23 & 390 & 126 & 36 & 78 & 90 & 38 & 62 & 42 & 16 & 20 & 25 & 85 & 254 \\
\hline 6 & Y13 & $\mathrm{M}$ & 508 & 253 & 993 & 56 & 37 & 321 & 110 & 319 & 835 & 16 & 31 & 114 & 298 & 483 & 89 & 27 & 36 & 162 \\
\hline 7 & Y14 & $\mathrm{M}$ & 621 & 726 & 1546 & 486 & 108 & 322 & 142 & 27 & 17 & 23 & 170 & 23 & 19 & 34 & 19 & 101 & 90 & 201 \\
\hline 8 & Y15 & $\mathrm{M}$ & 266 & 801 & 57 & 88 & 31 & 93 & 27 & 20 & 22 & 18 & 219 & 46 & 49 & 21 & 16 & 204 & 158 & 69 \\
\hline 9 & Y16 & $\mathrm{M}$ & 923 & 714 & 265 & 27 & 134 & 153 & 60 & 30 & 245 & 65 & 200 & 160 & 147 & 14 & 11 & 93 & 36 & 325 \\
\hline 10 & Y05 & $\mathrm{F}$ & 272 & 794 & 117 & 325 & 191 & 641 & 860 & 33 & 20 & 20 & 118 & 18 & 15 & 16 & 14 & 54 & 69 & 60 \\
\hline 11 & y06 & $\mathrm{F}$ & 1630 & 43 & 42 & 183 & 293 & 127 & 37 & 354 & 721 & 257 & 213 & 26 & 68 & 415 & 67 & 53 & 44 & 205 \\
\hline 12 & Y07 & $\mathrm{F}$ & 512 & 143 & 314 & 237 & 203 & 310 & 563 & 136 & 55 & 184 & 76 & 255 & 132 & 214 & 36 & 140 & 344 & 562 \\
\hline 13 & y26 & $\mathrm{F}$ & 248 & 741 & 335 & 170 & 249 & 140 & 137 & 116 & 188 & 120 & 294 & 686 & 53 & 159 & 42 & 195 & 358 & 1790 \\
\hline 14 & y27 & $\mathrm{F}$ & 126 & 240 & 172 & 185 & 76 & 343 & 156 & 170 & 55 & 127 & 210 & 47 & 26 & 40 & 25 & 91 & 44 & 90 \\
\hline 15 & y29 & $\mathrm{F}$ & 1402 & 1227 & 679 & 27 & 44 & 160 & 29 & 30 & 12 & 13 & 136 & 26 & 16 & 62 & 26 & 26 & 24 & 42 \\
\hline 16 & $\mathrm{y} 32$ & $\mathrm{~F}$ & 1784 & 378 & 71 & 26 & 133 & 208 & 86 & 118 & 24 & 33 & 253 & 76 & 42 & 18 & 10 & 85 & 76 & 1530 \\
\hline 17 & y28 & $\mathrm{F}$ & 284 & 96 & 119 & 29 & 52 & 144 & 40 & 1187 & 1111 & 191 & 465 & 354 & 25 & 185 & 66 & 146 & 187 & 627 \\
\hline 18 & y33 & $\mathrm{F}$ & 147 & 75 & 42 & 62 & 38 & 51 & 141 & 69 & 69 & 122 & 55 & 228 & 33 & 16 & 15 & 35 & 40 & 816 \\
\hline
\end{tabular}


Anexo II - Dados brutos referentes à variável de NER - Número de erros cometidos para a espécie T.yonenagae em todas os testes (T1-T18) no labirinto complexo.

\begin{tabular}{|c|c|c|c|c|c|c|c|c|c|c|c|c|c|c|c|c|c|c|c|c|}
\hline \# & Tag & sexo & $\mathrm{T} 1$ & $\mathrm{~T} 2$ & T3 & T4 & T5 & T6 & T7 & T8 & T9 & T10 & T11 & T12 & T13 & T14 & T15 & T16 & T17 & T18 \\
\hline 1 & Y01 & $\mathrm{M}$ & 5 & 5 & 63 & 6 & 4 & 28 & 3 & 2 & 2 & 1 & 12 & 21 & 17 & 14 & 9 & 20 & 5 & 139 \\
\hline 2 & Y02 & $\mathrm{M}$ & 18 & 6 & 49 & 142 & 32 & 2 & 206 & 41 & 15 & 25 & 32 & 65 & 1 & 2 & 16 & 4 & 3 & 9 \\
\hline 3 & Y04 & $\mathrm{M}$ & 144 & 154 & 5 & 3 & 152 & 56 & 2 & 1 & 6 & 17 & 11 & 2 & 10 & 21 & 17 & 42 & 25 & 62 \\
\hline 4 & $\mathrm{Y} 10$ & $\mathrm{M}$ & 19 & 5 & 17 & 55 & 12 & 3 & 8 & 9 & 47 & 2 & 15 & 0 & 77 & 9 & 15 & 7 & 20 & 19 \\
\hline 5 & Y11 & M & 98 & 4 & 38 & 20 & 0 & 52 & 18 & 6 & 12 & 16 & 1 & 2 & 6 & 0 & 3 & 1 & 10 & 17 \\
\hline 6 & Y13 & M & 82 & 62 & 119 & 10 & 5 & 47 & 15 & 32 & 142 & 35 & 3 & 37 & 83 & 203 & 36 & 3 & 9 & 10 \\
\hline 7 & Y14 & $\mathrm{M}$ & 33 & 70 & 202 & 60 & 13 & 20 & 17 & 1 & 0 & 3 & 29 & 3 & 3 & 9 & 2 & 12 & 12 & 19 \\
\hline 8 & Y15 & $\mathrm{M}$ & 28 & 144 & 10 & 11 & 0 & 1 & 0 & 0 & 0 & 1 & 10 & 2 & 5 & 0 & 0 & 16 & 18 & 2 \\
\hline 9 & Y16 & M & 89 & 87 & 41 & 0 & 21 & 3 & 2 & 0 & 38 & 9 & 23 & 20 & 24 & 0 & 0 & 9 & 0 & 51 \\
\hline 10 & Y05 & $\mathrm{F}$ & 21 & 59 & 12 & 52 & 29 & 64 & 21 & 2 & 0 & 0 & 8 & 0 & 0 & 2 & 3 & 0 & 7 & 6 \\
\hline 11 & y06 & $\mathrm{F}$ & 189 & 0 & 1 & 20 & 8 & 2 & 1 & 64 & 134 & 52 & 14 & 0 & 7 & 30 & 13 & 0 & 1 & 0 \\
\hline 12 & Y07 & $\mathrm{F}$ & 49 & 10 & 48 & 27 & 35 & 15 & 103 & 31 & 5 & 45 & 1 & 40 & 22 & 35 & 4 & 11 & 48 & 98 \\
\hline 13 & y26 & $\mathrm{F}$ & 4 & 53 & 30 & 17 & 7 & 15 & 18 & 18 & 27 & 21 & 38 & 99 & 3 & 16 & 1 & 21 & 58 & 183 \\
\hline 14 & y27 & $\mathrm{F}$ & 2 & 23 & 18 & 17 & 5 & 15 & 15 & 20 & 5 & 20 & 14 & 2 & 6 & 16 & 2 & 11 & 2 & 5 \\
\hline 15 & y29 & $\mathrm{F}$ & 91 & 61 & 75 & 3 & 6 & 19 & 4 & 3 & 0 & 0 & 6 & 1 & 0 & 5 & 2 & 1 & 2 & 3 \\
\hline 16 & $\mathrm{y} 32$ & $\mathrm{~F}$ & 161 & 40 & 4 & 0 & 18 & 4 & 4 & 21 & 3 & 6 & 30 & 5 & 2 & 1 & 0 & 10 & 8 & 132 \\
\hline 17 & y28 & $\mathrm{F}$ & 20 & 5 & 14 & 1 & 3 & 8 & 1 & 0 & 215 & 32 & 99 & 91 & 2 & 65 & 17 & 11 & 27 & 161 \\
\hline 18 & y33 & $\mathrm{F}$ & 9 & 4 & 2 & 7 & 1 & 6 & 12 & 3 & 6 & 15 & 7 & 28 & 3 & 3 & 1 & 3 & 4 & 10 \\
\hline
\end{tabular}


Anexo III - Dados brutos referentes à variável de TFL - Tempo requerido para alcançar o fim do labirinto para a espécie T. i. denigratus em todas os testes (T1-T18) no labirinto complexo.

\begin{tabular}{|c|c|c|c|c|c|c|c|c|c|c|c|c|c|c|c|c|c|c|c|c|}
\hline \# & tag & $\begin{array}{l}\text { se } \\
\text { xo }\end{array}$ & $\mathrm{T} 1$ & $\mathrm{~T} 2$ & T3 & $\mathrm{T} 4$ & T5 & T6 & $\mathrm{T} 7$ & $\mathrm{~T} 8$ & T9 & $\mathrm{T} 10$ & $\mathrm{~T} 11$ & $\mathrm{~T} 12$ & T13 & T14 & $\mathrm{T} 15$ & T16 & T17 & $\mathrm{T} 18$ \\
\hline 1 & 02 & $\mathrm{M}$ & 1532 & 234 & 200 & 456 & 114 & 66 & 194 & 239 & 95 & 84 & 174 & 190 & 100 & 106 & 53 & 100 & 223 & 906 \\
\hline 2 & 162 & $\mathrm{M}$ & 1304 & 732 & 36 & 39 & 169 & 365 & 83 & 52 & 48 & 21 & 175 & 226 & 69 & 59 & 56 & 148 & 201 & 217 \\
\hline 3 & D04 & $\mathrm{M}$ & 360 & 82 & 323 & 72 & 189 & 162 & 72 & 123 & 52 & 44 & 80 & 71 & 44 & 52 & 64 & 75 & 82 & 110 \\
\hline 4 & D17 & $\mathrm{M}$ & 1022 & 588 & 213 & 762 & 333 & 218 & 42 & 156 & 136 & 77 & 63 & 110 & 60 & 98 & 50 & 136 & 206 & 343 \\
\hline 5 & D14 & M & 398 & 705 & 141 & 322 & 137 & 48 & 365 & 95 & 176 & 108 & 118 & 86 & 101 & 130 & 55 & 59 & 80 & 71 \\
\hline 6 & D10 & M & 108 & 529 & 233 & 167 & 406 & 405 & 204 & 148 & 466 & 202 & 227 & 362 & 85 & 495 & 423 & 231 & 258 & 217 \\
\hline 7 & D09 & $\mathrm{F}$ & 820 & 551 & 477 & 97 & 159 & 198 & 98 & 148 & 272 & 120 & 211 & 31 & 93 & 193 & 83 & 84 & 140 & 196 \\
\hline 8 & D07 & $\mathrm{F}$ & 322 & 424 & 324 & 127 & 60 & 99 & 30 & 38 & 44 & 56 & 110 & 30 & 14 & 12 & 23 & 257 & 302 & 115 \\
\hline 9 & D161 & $\mathrm{F}$ & 750 & 1101 & 1136 & 9 & 173 & 370 & 140 & 191 & 397 & 148 & 330 & 636 & 542 & 335 & 486 & 238 & 1032 & 402 \\
\hline 10 & D11 & $\mathrm{F}$ & 780 & 45 & 415 & 109 & 100 & 320 & 244 & 182 & 168 & 119 & 805 & 196 & 52 & 122 & 101 & 184 & 174 & 219 \\
\hline
\end{tabular}


Anexo IV - Dados brutos referentes à variável de NER - Número de erros cometidos para a espécie T.iheringi denigratus em todas os testes (T1T18) no labirinto complexo.

\begin{tabular}{|c|c|c|c|c|c|c|c|c|c|c|c|c|c|c|c|c|c|c|c|c|}
\hline \# & tag & $\begin{array}{l}\text { se } \\
\text { xo }\end{array}$ & $\mathrm{T} 1$ & $\mathrm{~T} 2$ & T3 & $\mathrm{T} 4$ & T5 & T6 & $\mathrm{T} 7$ & $\mathrm{~T} 8$ & T9 & $\mathrm{T} 10$ & $\mathrm{~T} 11$ & $\mathrm{~T} 12$ & $\mathrm{~T} 13$ & $\mathrm{~T} 14$ & T15 & T16 & T17 & $\mathrm{T} 18$ \\
\hline 1 & 02 & $\mathrm{M}$ & 232 & 29 & 21 & 62 & 13 & 1 & 26 & 28 & 9 & 8 & 18 & 26 & 10 & 19 & 5 & 11 & 28 & 119 \\
\hline 2 & 162 & $M$ & 116 & 80 & 1 & 3 & 16 & 62 & 20 & 8 & 9 & 2 & 34 & 35 & 10 & 13 & 8 & 33 & 22 & 34 \\
\hline 3 & D04 & $M$ & 18 & 6 & 42 & 1 & 14 & 3 & 8 & 11 & 5 & 4 & 5 & 6 & 1 & 5 & 3 & 5 & 4 & 7 \\
\hline 4 & D17 & M & 41 & 12 & 17 & 27 & 10 & 11 & 0 & 8 & 9 & 5 & 1 & 2 & 0 & 3 & 0 & 7 & 8 & 22 \\
\hline 5 & D14 & $M$ & 28 & 80 & 16 & 38 & 18 & 1 & 48 & 8 & 14 & 6 & 64 & 124 & 129 & 94 & 136 & 6 & 3 & \\
\hline 6 & D10 & $\mathrm{M}$ & 4 & 63 & 20 & 16 & 17 & 20 & 15 & 18 & 41 & 12 & 11 & 12 & 2 & 15 & 7 & 12 & 13 & 17 \\
\hline 7 & D09 & $\mathrm{F}$ & 100 & 68 & 26 & 9 & 26 & 17 & 12 & 27 & 33 & 20 & 19 & 1 & 17 & 29 & 9 & 6 & 20 & 27 \\
\hline 8 & D07 & $\mathrm{F}$ & 13 & 15 & 19 & 1 & 2 & 0 & 0 & 2 & 4 & 5 & 8 & 0 & 0 & 0 & 2 & 21 & 35 & 8 \\
\hline 9 & D161 & $\mathrm{F}$ & 64 & 61 & 67 & 54 & 8 & 23 & 13 & 19 & 30 & 11 & 12 & 7 & 8 & 16 & 3 & 31 & 126 & 56 \\
\hline 10 & D11 & $\mathrm{F}$ & 82 & 3 & 66 & 13 & 14 & 27 & 26 & 22 & 24 & 17 & 34 & 24 & 5 & 11 & 12 & 15 & 21 & 32 \\
\hline
\end{tabular}


Anexo V - Dados brutos referentes à variável de TFL - Tempo requerido para alcançar o fim do labirinto para a espécie Clyomys bishopi em todas os testes (T1-T18) no labirinto complexo.

\begin{tabular}{|r|l|l|r|r|r|r|r|r|r|r|r|r|r|r|r|r|r|r|r|r|}
\hline$\#$ & tag & sexo & T1 & T2 & T3 & T4 & T5 & T6 & T7 & T8 & T9 & T10 & T11 & T12 & T13 & T14 & T15 & T16 & T17 & T18 \\
\hline 1 & C06 & M & 929 & 243 & 164 & 39 & 169 & 317 & 131 & 102 & 168 & 21 & 41 & 20 & 233 & 354 & 24 & 96 & 86 & 57 \\
\hline 2 & C05 & M & 430 & 184 & 432 & 204 & 429 & 10 & 218 & 123 & 485 & 368 & 70 & 117 & 44 & 16 & 232 & 157 & 27 & 21 \\
\hline 3 & C01 & M & 465 & 201 & 398 & 257 & 64 & 60 & 197 & 352 & 31 & 305 & 21 & 78 & 78 & 168 & 38 & 105 & 376 & 82 \\
\hline 4 & C03 & F & 1346 & 188 & 43 & 24 & 20 & 353 & 40 & 48 & 104 & 174 & 47 & 52 & 128 & 126 & 197 & 79 & 166 & 52 \\
\hline 5 & C10 & F & 109 & 56 & 95 & 102 & 254 & 99 & 14 & 63 & 139 & 147 & 217 & 164 & 45 & 91 & 82 & 28 & 54 & 281 \\
\hline 6 & C08 & F & 290 & 197 & 52 & 65 & 117 & 96 & 67 & 391 & 92 & 672 & 59 & 63 & 48 & 153 & 577 & 161 & 84 & 38 \\
\hline
\end{tabular}


Anexo VI - Dados brutos referentes à variável de NER - Número de erros cometidos para a espécie Clyomys bishopi em todas os testes (T1-T18) no labirinto complexo.

\begin{tabular}{|r|l|l|l|r|r|r|r|r|r|r|r|r|r|r|r|r|r|r|r|r|}
\hline$\#$ & tag & Sexo & T1 & T2 & T3 & T4 & T5 & T6 & T7 & T8 & T9 & T10 & T11 & T12 & T13 & T14 & T15 & T16 & T17 & T18 \\
\hline 1 & C06 & M & 66 & 29 & 20 & 16 & 3 & 29 & 20 & 12 & 14 & 35 & 3 & 3 & 29 & 17 & 10 & 5 & 3 & 4 \\
\hline 2 & C05 & M & 41 & 35 & 51 & 18 & 34 & 10 & 24 & 10 & 46 & 22 & 10 & 16 & 39 & 5 & 11 & 24 & 0 & 0 \\
\hline 3 & C01 & M & 29 & 22 & 47 & 31 & 4 & 1 & 20 & 30 & 4 & 54 & 2 & 34 & 13 & 22 & 3 & 8 & 37 & 6 \\
\hline 4 & C03 & F & 146 & 20 & 3 & 0 & 1 & 29 & 0 & 2 & 14 & 24 & 0 & 0 & 11 & 24 & 24 & 2 & 7 & 1 \\
\hline 5 & C10 & F & 15 & 10 & 24 & 23 & 59 & 7 & 0 & 19 & 47 & 37 & 29 & 52 & 10 & 22 & 6 & 0 & 0 & 76 \\
\hline 6 & C08 & F & 37 & 21 & 1 & 1 & 9 & 1 & 1 & 51 & 6 & 64 & 1 & 0 & 0 & 15 & 29 & 11 & 2 & 0 \\
\hline
\end{tabular}


Anexo VII - Dados brutos contínuos por espécie de roedor da massa do encéfalo (ME) em gramas, massa do corpo (MC) em gramas, Log da massa do encéfalo (Log_ME), Log da massa do corpo $(\mathrm{MC})$, quociente de encefalização $(\mathrm{QE})$, constraste filogenético do quociente de encefalização (ContrasQE).

\begin{tabular}{|c|c|c|c|c|c|c|}
\hline Espécies & $\mathrm{ME}$ & $\mathrm{MC}$ & Log_ME & Log_MC & QE & ContrasQE \\
\hline Acomys_cahirinus & 0.76 & 44 & -0.1192 & 1.6435 & 0.67 & -0.0608 \\
\hline Acomys_wilsoni & 0.58 & 18.5 & -0.2366 & 1.2672 & 0.85 & -0.1718 \\
\hline Aconaemys_porteri & 1.5436 & 132.33 & 0.1885 & 2.1217 & 0.72 & 0.0679 \\
\hline Aconaemys_sagei & 1.5229 & 116 & 0.1827 & 2.0645 & 0.77 & 0.0683 \\
\hline Aeromys_tephromelas & 10.93 & 1189 & 1.0386 & 3.0752 & 1.41 & 0.2259 \\
\hline Aethomys_chrysophilus & 1.545 & 117 & 0.1889 & 2.0682 & 0.77 & 0.0705 \\
\hline Aethomys_hindei & 1.715 & 146.3 & 0.2343 & 2.1652 & 0.75 & 0.0821 \\
\hline Aethomys_namaquensis & 1.185 & 79.4 & 0.0737 & 1.8998 & 0.74 & 0.0309 \\
\hline Agouti_paca & 35.51 & 5121 & 1.5504 & 3.7094 & 1.96 & 0.2612 \\
\hline Akodon_azarae & 0.64 & 25 & -0.1938 & 1.3979 & 0.79 & -0.1231 \\
\hline Allactaga_sibirica & 3.5 & 193 & 0.5441 & 2.2856 & 1.31 & 0.1771 \\
\hline Ammospermophilus_harrisii & 2.24 & 138.80 & 0.3502 & 2.1424 & 1.02 & 0.1245 \\
\hline Ammospermophilus_leucurus & 2.33 & 105.90 & 0.3674 & 2.0249 & 1.24 & 0.1410 \\
\hline Ammospermophilus_nelsoni & 2.31 & 70.00 & 0.3636 & 1.8451 & 1.56 & 0.1584 \\
\hline Aplodontia_rufa & 7.335 & 806 & 0.8654 & 2.9063 & 1.19 & 0.2032 \\
\hline Apodemus_agrarius & 0.2 & 33.3 & -0.6990 & 1.5224 & 0.21 & -0.3954 \\
\hline Apodemus_flavicollis & 0.995 & 32.3 & -0.0022 & 1.5092 & 1.06 & -0.0012 \\
\hline Apodemus_sylvaticus & 0.88 & 19.35 & -0.0555 & 1.2867 & 1.26 & -0.0395 \\
\hline Arvicanthis_niloticus & 1.625 & 84.5 & 0.2109 & 1.9269 & 0.98 & 0.0866 \\
\hline Arvicola_terrestris & 1.935 & 168.3 & 0.2867 & 2.2261 & 0.78 & 0.0967 \\
\hline Atherurus_africanus & 20.475 & 2918.75 & 1.3112 & 3.4652 & 1.57 & 0.2424 \\
\hline Bathyergus_janetta & 2.06 & 268 & 0.3139 & 2.4281 & 0.64 & 0.0941 \\
\hline Bathyergus_suillus & 4.045 & 1175 & 0.6069 & 3.0700 & 0.53 & 0.1323 \\
\hline Beamys_hindei & 1.11 & 89.75 & 0.0453 & 1.9530 & 0.65 & 0.0183 \\
\hline Berylmys_bowersi & 4.63 & 360.7 & 0.6656 & 2.5571 & 1.20 & 0.1860 \\
\hline Callistomys pictus & 3.23 & 500 & 0.5092 & 2.6990 & 0.69 & 0.1322 \\
\hline Callosciurus_caniceps & 6.315 & 240 & 0.8004 & 2.3802 & 2.08 & 0.2466 \\
\hline Callosciurus_nigrovittatus & 4.735 & 202 & 0.6753 & 2.3054 & 1.72 & 0.2173 \\
\hline Callosciurus_notatus & 5.205 & 209.5 & 0.7164 & 2.3212 & 1.86 & 0.2284 \\
\hline Callosciurus prevostii & 6.815 & 439 & 0.8335 & 2.6425 & 1.58 & 0.2228 \\
\hline Calomys_callosus & 0.58 & 54 & -0.2366 & 1.7324 & 0.46 & -0.1123 \\
\hline Capromys pilorides & 11.9 & 4989.5 & 1.0755 & 3.6981 & 0.67 & 0.1820 \\
\hline Carterodon_sulcidens & 1.55 & 158 & 0.1903 & 2.1987 & 0.65 & 0.0653 \\
\hline Castor_canadensis & 46.105 & 23835 & 1.6637 & 4.3772 & 1.04 & 0.2238 \\
\hline Castor fiber & 45 & 25000 & 1.6532 & 4.3979 & 0.98 & 0.2210 \\
\hline Cavia aperea & 4.95 & 415.675 & 0.6946 & 2.6188 & 1.18 & 0.1879 \\
\hline
\end{tabular}




\begin{tabular}{|c|c|c|c|c|c|c|}
\hline Cavia_pamparum & 5.1903 & 549 & 0.7152 & 2.7396 & 1.05 & 0.1820 \\
\hline Cavia_porcellus & 3.96 & 423.5 & 0.5977 & 2.6269 & 0.94 & 0.1610 \\
\hline Chaetodipus_baileyi & 1.01 & 29.025 & 0.0043 & 1.4628 & 1.14 & 0.0026 \\
\hline Chaetodipus_californicus & 0.61 & 26 & -0.2147 & 1.4150 & 0.74 & -0.1342 \\
\hline Chaetodipus fallax & 0.53 & 20 & -0.2757 & 1.3010 & 0.74 & -0.1932 \\
\hline Chaetodipus_formosus & 0.81 & 19.5 & -0.0915 & 1.2900 & 1.16 & -0.0649 \\
\hline Chaetodipus_hispidus & 0.975 & 38.05 & -0.0110 & 1.5804 & 0.94 & -0.0059 \\
\hline Chaetodipus penicillatus & 0.76 & 16.1 & -0.1192 & 1.2068 & 1.21 & -0.0925 \\
\hline Chaetomys_subspinosus & 11.99 & 1750 & 1.0788 & 3.2430 & 1.24 & 0.2182 \\
\hline Chinchilla_lanigera & 5.25 & 432 & 0.7202 & 2.6355 & 1.23 & 0.1932 \\
\hline Chiropodomys_gliroides & 0.995 & 25.3 & -0.0022 & 1.4031 & 1.22 & -0.0014 \\
\hline Clethrionomys_gapperi & 0.855 & 16.9 & -0.0680 & 1.2279 & 1.33 & -0.0516 \\
\hline Clethrionomys_glareolus & 0.815 & 17.9 & -0.0888 & 1.2529 & 1.22 & -0.0655 \\
\hline Clethrionomys_rufocanus & 0.905 & 38.3 & -0.0434 & 1.5832 & 0.87 & -0.0233 \\
\hline Clethrionomys_rutilus & 0.855 & 17.6 & -0.0680 & 1.2455 & 1.29 & -0.0506 \\
\hline Clyomys_bishopi & 3.25 & 338 & 0.5119 & 2.5289 & 0.88 & 0.1452 \\
\hline Cricetomys_gambianus & 6.865 & 1150 & 0.8366 & 3.0607 & 0.91 & 0.1831 \\
\hline Cricetulus_barabensis & 0.67 & 36 & -0.1739 & 1.5563 & 0.67 & -0.0955 \\
\hline Cricetus_cricetus & 1.695 & 214.5 & 0.2292 & 2.3314 & 0.60 & 0.0726 \\
\hline Cryptomys_hottentotus & 1.465 & 98.4 & 0.1658 & 1.9930 & 0.81 & 0.0650 \\
\hline Ctenomys_argentinus & 1.9580 & 146.6 & 0.2918 & 2.1661 & 0.86 & 0.1022 \\
\hline Ctenomys_australis & 2.4035 & 371.1 & 0.3808 & 2.5695 & 0.61 & 0.1057 \\
\hline Ctenomys_azarae & 1.9166 & 138 & 0.2825 & 2.1399 & 0.87 & 0.1006 \\
\hline Ctenomys_boliviensis & 2.8800 & 535 & 0.4594 & 2.7284 & 0.59 & 0.1176 \\
\hline Ctenomys_bonettoi & 1.6576 & 141 & 0.2195 & 2.1492 & 0.74 & 0.0777 \\
\hline Ctenomys_chasiquensis & 1.5332 & 140.7 & 0.1856 & 2.1483 & 0.69 & 0.0657 \\
\hline Ctenomys_dorbignyi & 2.5589 & 237.3 & 0.4081 & 2.3753 & 0.85 & 0.1261 \\
\hline Ctenomys_emilianus & 2.0409 & 154.5 & 0.3098 & 2.1889 & 0.87 & 0.1070 \\
\hline Ctenomys_flamarioni & 2.5382 & 300 & 0.4045 & 2.4771 & 0.73 & 0.1180 \\
\hline Ctenomys fulvus & 2.9526 & 300 & 0.4702 & 2.4771 & 0.85 & 0.1372 \\
\hline Ctenomys_haigi & 1.3468 & 76.3 & 0.1293 & 1.8825 & 0.87 & 0.0548 \\
\hline Ctenomys_lami & 2.59 & 229 & 0.4133 & 2.3598 & 0.88 & 0.1288 \\
\hline Ctenomys_latro & 1.6058 & 122.1 & 0.2057 & 2.0867 & 0.78 & 0.0758 \\
\hline Ctenomys_leucodon & 2.9318 & 220 & 0.4671 & 2.3424 & 1.02 & 0.1471 \\
\hline Ctenomys_magellanicus & 2.9111 & 234.7 & 0.4641 & 2.3705 & 0.97 & 0.1438 \\
\hline Ctenomys_maulinus & 2.0202 & 215 & 0.3054 & 2.3324 & 0.71 & 0.0967 \\
\hline Ctenomys_mendocinus & 2.1238 & 192.5 & 0.3271 & 2.2844 & 0.80 & 0.1066 \\
\hline Ctenomys_minutus & 2.2895 & 225 & 0.3598 & 2.3522 & 0.78 & 0.1126 \\
\hline Ctenomys_occultus & 1.6368 & 95 & 0.2140 & 1.9777 & 0.93 & 0.0848 \\
\hline Ctenomys_opimus & 3.2426 & 230.6 & 0.5109 & 2.3629 & 1.09 & 0.1590 \\
\hline Ctenomys_perrensis & 2.4967 & 166 & 0.3974 & 2.2201 & 1.02 & 0.1346 \\
\hline
\end{tabular}




\begin{tabular}{|c|c|c|c|c|c|c|}
\hline Ctenomys_porteousi & 1.8440 & 185.2 & 0.2658 & 2.2676 & 0.71 & 0.0875 \\
\hline Ctenomys_pundti & 1.7612 & 141.2 & 0.2458 & 2.1498 & 0.79 & 0.0870 \\
\hline Ctenomys_rionegrensis & 2.1445 & 235 & 0.3313 & 2.3711 & 0.71 & 0.1026 \\
\hline Ctenomys_roigi & 2.5278 & 179 & 0.4027 & 2.2529 & 0.99 & 0.1337 \\
\hline Ctenomys_sociabilis & 2.0512 & 148.3 & 0.3120 & 2.1711 & 0.89 & 0.1089 \\
\hline Ctenomys_talarum & 1.4089 & 134.6 & 0.1489 & 2.1290 & 0.65 & 0.0534 \\
\hline Ctenomys_torquatus & 2.5174 & 209.5 & 0.4010 & 2.3212 & 0.90 & 0.1278 \\
\hline Ctenomys_tuconax & 3.9264 & 550 & 0.5940 & 2.7404 & 0.80 & 0.1511 \\
\hline Ctenomys_tucumanus & 2.0927 & 240 & 0.3207 & 2.3802 & 0.69 & 0.0988 \\
\hline Cynomys_gunnisoni & 5.455 & 796.3 & 0.7368 & 2.9011 & 0.89 & 0.1734 \\
\hline Cynomys_leucurus & 5.985 & 992.1 & 0.7771 & 2.9966 & 0.86 & 0.1750 \\
\hline Cynomys_ludovicianus & 6.305 & 793.5 & 0.7997 & 2.8995 & 1.03 & 0.1884 \\
\hline Dactylomys_dactylinus & 5.67 & 675 & 0.7536 & 2.8293 & 1.02 & 0.1835 \\
\hline Dasyprocta_leporina & 20.78 & 2836.5 & 1.3176 & 3.4528 & 1.62 & 0.2448 \\
\hline Dasyprocta_prymnolopha & 21.62 & 2900 & 1.3349 & 3.4624 & 1.66 & 0.2470 \\
\hline Dasyprocta_punctata & 18.34 & 3172 & 1.2634 & 3.5013 & 1.34 & 0.2303 \\
\hline Dendromus_mystacalis & 0.39 & 8 & -0.4089 & 0.9031 & 0.94 & -0.4707 \\
\hline Dicrostonyx_groenlandicus & 1.015 & 68.4 & 0.0065 & 1.8351 & 0.70 & 0.0028 \\
\hline Dicrostonyx_torquatus & 1.135 & 73 & 0.0550 & 1.8633 & 0.75 & 0.0236 \\
\hline Dinomys_branickii & 27.54 & 14000 & 1.4400 & 4.1461 & 0.84 & 0.2086 \\
\hline Dipodomys_agilis & 1.635 & 61.4 & 0.2135 & 1.7882 & 1.19 & 0.0971 \\
\hline Dipodomys_deserti & 2.035 & 126.325 & 0.3086 & 2.1015 & 0.97 & 0.1126 \\
\hline Dipodomys_heermanni & 1.705 & 62.825 & 0.2317 & 1.7981 & 1.23 & 0.1045 \\
\hline Dipodomys_merriami & 1.37 & 38.6 & 0.1367 & 1.5866 & 1.31 & 0.0731 \\
\hline Dipodomys_microps & 1.51 & 58.5 & 0.1790 & 1.7672 & 1.13 & 0.0827 \\
\hline Dipodomys_ordii & 1.71 & 55.55 & 0.2330 & 1.7447 & 1.32 & 0.1095 \\
\hline Dipodomys_panamintinus & 1.57 & 74 & 0.1959 & 1.8692 & 1.03 & 0.0838 \\
\hline Dipodomys_spectabilis & 2.065 & 132.775 & 0.3149 & 2.1231 & 0.96 & 0.1133 \\
\hline Dolichotis_patagonum & 28.1 & 6825 & 1.4487 & 3.8341 & 1.31 & 0.2334 \\
\hline Dremomys_rufigenis & 5.705 & 240 & 0.7563 & 2.3802 & 1.88 & 0.2330 \\
\hline Echimys_chrysurus & 3.63 & 640 & 0.5599 & 2.8062 & 0.67 & 0.1379 \\
\hline Erethizon_dorsatum & 24.895 & 5397 & 1.3961 & 3.7322 & 1.33 & 0.2333 \\
\hline Euryzygomatomys_spinosus & 2.83 & 200 & 0.4518 & 2.3010 & 1.04 & 0.1457 \\
\hline Fukomys_anselli & 1.23 & 68.3 & 0.0899 & 1.8344 & 0.84 & 0.0395 \\
\hline Fukomys_mechowi & 2.28 & 265 & 0.3579 & 2.4232 & 0.71 & 0.1076 \\
\hline Funambulus_pennantii & 2.1 & 85.9 & 0.3222 & 1.9340 & 1.26 & 0.1317 \\
\hline Funisciurus_anerythrus & 4.185 & 224 & 0.6217 & 2.3502 & 1.43 & 0.1949 \\
\hline Funisciurus_carruthersi & 4.775 & 268 & 0.6790 & 2.4281 & 1.47 & 0.2036 \\
\hline Funisciurus_lemniscatus & 3.38 & 154 & 0.5289 & 2.1875 & 1.44 & 0.1828 \\
\hline Funisciurus_pyrropus & 4.675 & 200 & 0.6698 & 2.3010 & 1.71 & 0.2161 \\
\hline Funisciurus_substriatus & 3.89 & 186.1 & 0.5899 & 2.2697 & 1.49 & 0.1939 \\
\hline
\end{tabular}




\begin{tabular}{|c|c|c|c|c|c|c|}
\hline Galea_musteloides & 3.015 & 375 & 0.4793 & 2.5740 & 0.77 & 0.1327 \\
\hline Galea_spixii & 3.3255 & 450 & 0.5219 & 2.6532 & 0.76 & 0.1387 \\
\hline Geocapromys_ingrahami & 4.755 & 717.3 & 0.6772 & 2.8557 & 0.83 & 0.1628 \\
\hline Geomys_bursarius & 2.23 & 199.675 & 0.3483 & 2.3003 & 0.82 & 0.1124 \\
\hline Geomys_pinetis & 2.465 & 313.5 & 0.3918 & 2.4962 & 0.69 & 0.1131 \\
\hline Georychus_capensis & 1 & 343 & 0.0000 & 2.5353 & 0.27 & 0.0000 \\
\hline Gerbillurus_paeba & 1.135 & 24 & 0.0550 & 1.3802 & 1.43 & 0.0356 \\
\hline Gerbillus_campestris & 1.195 & 27.5 & 0.0774 & 1.4393 & 1.39 & 0.0472 \\
\hline Gerbillus_dasyurus & 1.32 & 20.5 & 0.1206 & 1.3118 & 1.83 & 0.0835 \\
\hline Gerbillus_gleadowi & 0.985 & 26.1 & -0.0066 & 1.4166 & 1.19 & -0.0041 \\
\hline Gerbillus_pyramidum & 1.175 & 40.9 & 0.0700 & 1.6117 & 1.09 & 0.0367 \\
\hline Glaucomys_sabrinus & 3.305 & 174 & 0.5192 & 2.2405 & 1.31 & 0.1737 \\
\hline Glaucomys_volans & 2.05 & 73.1 & 0.3118 & 1.8639 & 1.35 & 0.1339 \\
\hline Glis_glis & 1.9 & 148 & 0.2788 & 2.1703 & 0.83 & 0.0974 \\
\hline Grammomys_cometes & 0.96 & 40.7 & -0.0177 & 1.6096 & 0.89 & -0.0093 \\
\hline Grammomys_dolichurus & 1.98 & 45 & 0.2967 & 1.6532 & 1.73 & 0.1500 \\
\hline Grammomys_rutilans & 1.55 & 50.2 & 0.1903 & 1.7007 & 1.27 & 0.0926 \\
\hline Graphiurus_murinus & 0.71 & 22.3 & -0.1487 & 1.3483 & 0.94 & -0.0993 \\
\hline Heliophobius_argenteocinereus & 1.725 & 160 & 0.2368 & 2.2041 & 0.72 & 0.0810 \\
\hline Heliosciurus_gambianus & 4.58 & 295 & 0.6609 & 2.4698 & 1.34 & 0.1936 \\
\hline Heliosciurus_rufobrachium & 5.165 & 326.5 & 0.7131 & 2.5139 & 1.42 & 0.2040 \\
\hline Heliosciurus_ruwenzorii & 5.695 & 291 & 0.7555 & 2.4639 & 1.68 & 0.2221 \\
\hline Heterocephalus_glaber & 0.815 & 60.8 & -0.0888 & 1.7839 & 0.60 & -0.0405 \\
\hline Heteromys_desmarestianus & 1.4 & 73.425 & 0.1461 & 1.8658 & 0.92 & 0.0627 \\
\hline Holochilus_chacarius & 1.61 & 204 & 0.2068 & 2.3096 & 0.58 & 0.0664 \\
\hline Holochilus_sciureus & 1.705 & 112.3 & 0.2317 & 2.0504 & 0.87 & 0.0874 \\
\hline Hoplomys_gymnurus & 4.425 & 330 & 0.6459 & 2.5185 & 1.21 & 0.1843 \\
\hline Hybomys_trivirgatus & 1.69 & 57.5 & 0.2279 & 1.7597 & 1.28 & 0.1059 \\
\hline Hydrochaeris_hydrochaeris & 75.5 & 29000 & 1.8779 & 4.4624 & 1.51 & 0.2461 \\
\hline Hydromys_chrysogaster & 4.625 & 698 & 0.6651 & 2.8439 & 0.82 & 0.1609 \\
\hline Hylopetes_spadiceus & 1.87 & 87.5 & 0.2718 & 1.9420 & 1.11 & 0.1104 \\
\hline Hystrix_africaeaustralis & 21.7 & 17650 & 1.3365 & 4.2467 & 0.58 & 0.1874 \\
\hline Hystrix_cristata & 24.2 & 4763 & 1.3838 & 3.6779 & 1.39 & 0.2359 \\
\hline Iomys_horsfieldii & 3.675 & 155.5 & 0.5653 & 2.1917 & 1.56 & 0.1948 \\
\hline Isothrix_bistriata & 3.51 & 445 & 0.5453 & 2.6484 & 0.81 & 0.1453 \\
\hline Isthmomys_pirrensis & 1.71 & 138 & 0.2330 & 2.1399 & 0.78 & 0.0830 \\
\hline Jaculus_jaculus & 1.665 & 59.8 & 0.2214 & 1.7767 & 1.23 & 0.1015 \\
\hline Jaculus_orientalis & 2.57 & 119 & 0.4099 & 2.0755 & 1.27 & 0.1522 \\
\hline Kannabateomys_amblyonyx & 4.7 & 530 & 0.6721 & 2.7243 & 0.97 & 0.1723 \\
\hline Kerodon_rupestris & 6.2885 & 950 & 0.7985 & 2.9777 & 0.93 & 0.1814 \\
\hline Lagidium_viscacia & 15.45 & 2415.25 & 1.1889 & 3.3830 & 1.32 & 0.2271 \\
\hline
\end{tabular}




\begin{tabular}{|c|c|c|c|c|c|c|}
\hline Lagostomus_maximus & 17.11 & 4687.5 & 1.2333 & 3.6709 & 0.99 & 0.2108 \\
\hline Lemmus_lemmus & 1.155 & 68.9 & 0.0626 & 1.8382 & 0.79 & 0.0274 \\
\hline Lemmus_sibiricus & 1.49 & 70 & 0.1732 & 1.8451 & 1.01 & 0.0754 \\
\hline Lemniscomys_rosalia & 0.63 & 59 & -0.2007 & 1.7709 & 0.47 & -0.0924 \\
\hline Lemniscomys_striatus & 1.145 & 46.2 & 0.0588 & 1.6646 & 0.99 & 0.0295 \\
\hline Leopoldamys_edwardsi & 4.81 & 332.1 & 0.6821 & 2.5213 & 1.31 & 0.1943 \\
\hline Leopoldamys_sabanus & 3.98 & 332.7 & 0.5999 & 2.5221 & 1.08 & 0.1708 \\
\hline Liomys_irroratus & 1.04 & 57.7 & 0.0170 & 1.7612 & 0.79 & 0.0079 \\
\hline Liomys_pictus & 1.065 & 45.7 & 0.0273 & 1.6599 & 0.92 & 0.0138 \\
\hline Liomys_salvini & 1.065 & 44.9 & 0.0273 & 1.6522 & 0.93 & 0.0138 \\
\hline Lonchothrix_emiliae & 2.3 & 237 & 0.3617 & 2.3747 & 0.76 & 0.1118 \\
\hline Lophuromys_flavopunctatus & 1.305 & 60 & 0.1156 & 1.7782 & 0.97 & 0.0530 \\
\hline Lophuromys_sikapusi & 1.425 & 60.7 & 0.1538 & 1.7832 & 1.05 & 0.0702 \\
\hline Makalata_armata & 2.65 & 251 & 0.4232 & 2.3997 & 0.85 & 0.1290 \\
\hline Malacomys_edwardsi & 1.475 & 60 & 0.1688 & 1.7782 & 1.09 & 0.0773 \\
\hline Malacothrix_typica & 0.54 & 124 & -0.2676 & 2.0934 & 0.26 & -0.0982 \\
\hline Marmota_flaviventris & 10.88 & 5000 & 1.0366 & 3.6990 & 0.61 & 0.1753 \\
\hline Marmota_marmota & 17 & 3500 & 1.2304 & 3.5441 & 1.17 & 0.2206 \\
\hline Marmota_monax & 11.035 & 3911.62 & 1.0428 & 3.5924 & 0.71 & 0.1835 \\
\hline Marmota_sibirica & 18.1 & 1890 & 1.2577 & 3.2765 & 1.79 & 0.2509 \\
\hline Massoutiera_mzabi & 2.615 & 182.6 & 0.4175 & 2.2615 & 1.01 & 0.1379 \\
\hline Mastomys_coucha & 0.71 & 21.8 & -0.1487 & 1.3385 & 0.95 & -0.1003 \\
\hline Mastomys_natalensis & 0.72 & 50 & -0.1427 & 1.6990 & 0.59 & -0.0695 \\
\hline Maxomys_rajah & 2.51 & 134.1 & 0.3997 & 2.1274 & 1.16 & 0.1434 \\
\hline Maxomys_surifer & 1.72 & 95.5 & 0.2355 & 1.9800 & 0.97 & 0.0932 \\
\hline Maxomys_whiteheadi & 2.57 & 159.1 & 0.4099 & 2.2017 & 1.08 & 0.1404 \\
\hline Megadontomys_thomasi & 1.635 & 94 & 0.2135 & 1.9731 & 0.93 & 0.0849 \\
\hline Melomys_cervinipes & 1.605 & 70 & 0.2055 & 1.8451 & 1.09 & 0.0895 \\
\hline Melomys_levipes & 2.155 & 83.4 & 0.3334 & 1.9212 & 1.32 & 0.1375 \\
\hline Melomys_rubex & 1.565 & 49.7 & 0.1945 & 1.6964 & 1.29 & 0.0950 \\
\hline Melomys_rufescens & 1.585 & 54.7 & 0.2000 & 1.7380 & 1.24 & 0.0945 \\
\hline Meriones_crassus & 1.36 & 122 & 0.1335 & 2.0864 & 0.66 & 0.0492 \\
\hline Meriones_hurrianae & 1.26 & 71.3 & 0.1004 & 1.8531 & 0.84 & 0.0435 \\
\hline Meriones_libycus & 1.51 & 93 & 0.1790 & 1.9685 & 0.86 & 0.0714 \\
\hline Meriones_shawi & 1.48 & 140 & 0.1703 & 2.1461 & 0.67 & 0.0604 \\
\hline Meriones_unguiculatus & 1.425 & 57.4 & 0.1538 & 1.7589 & 1.08 & 0.0715 \\
\hline Mesembriomys_gouldii & 4.885 & 1110 & 0.6889 & 3.0453 & 0.66 & 0.1518 \\
\hline Mesocricetus_auratus & 1.12 & 125 & 0.0492 & 2.0969 & 0.54 & 0.0180 \\
\hline Microcavia_australis & 3.0458 & 269 & 0.4837 & 2.4298 & 0.94 & 0.1449 \\
\hline Microdipodops_megacephalus & 0.875 & 13.975 & -0.0580 & 1.1454 & 1.52 & -0.0483 \\
\hline Microdipodops_pallidus & 0.53 & 12.9 & -0.2757 & 1.1106 & 0.96 & -0.2395 \\
\hline
\end{tabular}




\begin{tabular}{|c|c|c|c|c|c|c|}
\hline Micromys_minutus & 0.585 & 6.4 & -0.2328 & 0.8062 & 1.60 & -0.3127 \\
\hline Microtus_agrestis & 0.95 & 27.35 & -0.0223 & 1.4370 & 1.11 & -0.0136 \\
\hline Microtus_arvalis & 0.845 & 30.4 & -0.0731 & 1.4829 & 0.93 & -0.0429 \\
\hline Microtus_californicus & 1.075 & 43.3 & 0.0314 & 1.6365 & 0.96 & 0.0161 \\
\hline Microtus_guentheri & 0.985 & 51.3 & -0.0066 & 1.7101 & 0.80 & -0.0032 \\
\hline Microtus_longicaudus & 0.995 & 47.4 & -0.0022 & 1.6758 & 0.84 & -0.0011 \\
\hline Microtus_montanus & 0.985 & 39.7 & -0.0066 & 1.5988 & 0.93 & -0.0035 \\
\hline Microtus_ochrogaster & 1.005 & 43.8 & 0.0022 & 1.6415 & 0.89 & 0.0011 \\
\hline Microtus_oregoni & 0.815 & 22 & -0.0888 & 1.3424 & 1.08 & -0.0596 \\
\hline Microtus_pennsylvanicus & 1.05 & 33.715 & 0.0212 & 1.5278 & 1.09 & 0.0119 \\
\hline Microtus_pinetorum & 0.855 & 24.9 & -0.0680 & 1.3962 & 1.06 & -0.0433 \\
\hline Microtus_townsendii & 1.175 & 45.8 & 0.0700 & 1.6609 & 1.02 & 0.0352 \\
\hline Microtus_xanthognathus & 0.94 & 89.1 & -0.0269 & 1.9499 & 0.55 & -0.0109 \\
\hline Mus_booduga & 0.605 & 14.6 & -0.2182 & 1.1644 & 1.02 & -0.1778 \\
\hline Mus_minutoides & 0.26 & 5 & -0.5850 & 0.6990 & 0.82 & -0.9541 \\
\hline Mus_musculus & 0.36 & 12 & -0.4437 & 1.0792 & 0.68 & -0.4008 \\
\hline Mus_platythrix & 0.795 & 29.2 & -0.0996 & 1.4654 & 0.90 & -0.0594 \\
\hline Mus_triton & 0.36 & 8.4 & -0.4437 & 0.9243 & 0.84 & -0.4948 \\
\hline Myocastor_coypus & 17.895 & 6176 & 1.2527 & 3.7907 & 0.88 & 0.2050 \\
\hline Myomys_daltoni & 0.975 & 35 & -0.0110 & 1.5441 & 0.99 & -0.0061 \\
\hline Myoprocta_acouchy & 9.9 & 782 & 0.9956 & 2.8932 & 1.64 & 0.2352 \\
\hline Myopus_schisticolor & 0.855 & 33.5 & -0.0680 & 1.5250 & 0.89 & -0.0384 \\
\hline Mystromys_albicaudatus & 1.43 & 80 & 0.1553 & 1.9031 & 0.89 & 0.0649 \\
\hline Nannospalax_ehrenbergi & 1.195 & 123.5 & 0.0774 & 2.0917 & 0.58 & 0.0284 \\
\hline Nannospalax_leucodon & 3 & 122 & 0.4771 & 2.0864 & 1.47 & 0.1758 \\
\hline Napaeozapus_insignis & 0.775 & 23.2 & -0.1107 & 1.3655 & 1.00 & -0.0726 \\
\hline Nectomys_squamipes & 3.24 & 331.1 & 0.5105 & 2.5200 & 0.88 & 0.1455 \\
\hline Neofiber_alleni & 3.015 & 270.5 & 0.4793 & 2.4322 & 0.93 & 0.1434 \\
\hline Neotoma_albigula & 2.465 & 223.1 & 0.3918 & 2.3485 & 0.85 & 0.1229 \\
\hline Neotoma_floridana & 3.335 & 257.7 & 0.5231 & 2.4111 & 1.05 & 0.1584 \\
\hline Neotoma_fuscipes & 2.955 & 193.3 & 0.4706 & 2.2862 & 1.10 & 0.1531 \\
\hline Neotoma_goldmani & 1.99 & 94.2 & 0.2989 & 1.9741 & 1.13 & 0.1188 \\
\hline Neotoma_lepida & 1.89 & 128.3 & 0.2765 & 2.1082 & 0.90 & 0.1005 \\
\hline Neotoma_mexicana & 2.21 & 169.5 & 0.3444 & 2.2292 & 0.89 & 0.1160 \\
\hline Neotoma_micropus & 2.955 & 378.3 & 0.4706 & 2.5778 & 0.75 & 0.1301 \\
\hline Neotoma_stephensi & 2.02 & 152.7 & 0.3054 & 2.1838 & 0.87 & 0.1058 \\
\hline Notomys_alexis & 1.255 & 37 & 0.0986 & 1.5682 & 1.23 & 0.0536 \\
\hline Nyctomys_sumichrasti & 1.375 & 60 & 0.1383 & 1.7782 & 1.02 & 0.0633 \\
\hline Ochrotomys_nuttalli & 1.28 & 22 & 0.1072 & 1.3424 & 1.70 & 0.0720 \\
\hline Octodon_degus & 2.2792 & 140 & 0.3578 & 2.1461 & 1.03 & 0.1269 \\
\hline Octodontomys_gliroides & 2.4138 & 90 & 0.3827 & 1.9542 & 1.41 & 0.1542 \\
\hline
\end{tabular}




\begin{tabular}{|c|c|c|c|c|c|c|}
\hline Octomys_mimax & 2.331 & 131 & 0.3675 & 2.1173 & 1.09 & 0.1328 \\
\hline Oenomys_hypoxanthus & 1.48 & 178 & 0.1703 & 2.2504 & 0.58 & 0.0566 \\
\hline Oligoryzomys_longicaudatus & 0.965 & 26.6 & -0.0155 & 1.4249 & 1.15 & -0.0096 \\
\hline Oligoryzomys_nigripes & 0.56 & 24 & -0.2518 & 1.3802 & 0.71 & -0.1628 \\
\hline Ondatra_zibethicus & 5.175 & 1254.67 & 0.7139 & 3.0985 & 0.65 & 0.1537 \\
\hline Onychomys_leucogaster & 0.78 & 26.895 & -0.1079 & 1.4297 & 0.92 & -0.0665 \\
\hline Onychomys_torridus & 0.55 & 19.71 & -0.2596 & 1.2947 & 0.78 & -0.1831 \\
\hline Orthogeomys_cherriei & 3.41 & 405 & 0.5328 & 2.6075 & 0.83 & 0.1450 \\
\hline Orthogeomys_heterodus & 4.235 & 630 & 0.6269 & 2.7993 & 0.79 & 0.1549 \\
\hline Orthogeomys_hispidus & 3.91 & 542.1 & 0.5922 & 2.7341 & 0.80 & 0.1511 \\
\hline Oryzomys_palustris & 1.175 & 47.1 & 0.0700 & 1.6730 & 1.00 & 0.0349 \\
\hline Otomys_angoniensis & 0.42 & 95 & -0.3768 & 1.9777 & 0.24 & -0.1493 \\
\hline Otomys_irroratus & 1.38 & 141 & 0.1399 & 2.1492 & 0.62 & 0.0495 \\
\hline Ototylomys_phyllotis & 1.625 & 63 & 0.2109 & 1.7993 & 1.17 & 0.0950 \\
\hline Pappogeomys_gymnurus & 4.115 & 637 & 0.6144 & 2.8041 & 0.77 & 0.1515 \\
\hline Paraxerus_cepapi & 3.115 & 219.9 & 0.4935 & 2.3422 & 1.08 & 0.1554 \\
\hline Paraxerus_poensis & 2.87 & 100 & 0.4579 & 2.0000 & 1.58 & 0.1787 \\
\hline Pectinator_spekei & 2.215 & 180 & 0.3454 & 2.2553 & 0.86 & 0.1145 \\
\hline Pedetes_capensis & 10.7 & 3156.5 & 1.0294 & 3.4992 & 0.78 & 0.1878 \\
\hline Perognathus flavus & 0.6 & 8.6 & -0.2218 & 0.9345 & 1.38 & -0.2437 \\
\hline Perognathus_longimembris & 0.63 & 8.225 & -0.2007 & 0.9151 & 1.49 & -0.2268 \\
\hline Perognathus_parvus & 0.48 & 17.3 & -0.3188 & 1.2380 & 0.73 & -0.2389 \\
\hline Peromyscus_aztecus & 0.92 & 37.6 & -0.0362 & 1.5752 & 0.89 & -0.0196 \\
\hline Peromyscus_boylii & 1.04 & 21.885 & 0.0170 & 1.3401 & 1.39 & 0.0115 \\
\hline Peromyscus_californicus & 1.225 & 38.965 & 0.0881 & 1.5907 & 1.17 & 0.0470 \\
\hline Peromyscus_crinitus & 0.875 & 14.48 & -0.0580 & 1.1608 & 1.49 & -0.0474 \\
\hline Peromyscus_eremicus & 0.885 & 20.615 & -0.0531 & 1.3142 & 1.22 & -0.0367 \\
\hline Peromyscus_gossypinus & 1.05 & 27.425 & 0.0212 & 1.4381 & 1.23 & 0.0130 \\
\hline Peromyscus_guatemalensis & 1.23 & 50.515 & 0.0899 & 1.7034 & 1.01 & 0.0437 \\
\hline Peromyscus_leucopus & 0.92 & 21.505 & -0.0362 & 1.3325 & 1.24 & -0.0246 \\
\hline Peromyscus_maniculatus & 0.88 & 20.775 & -0.0555 & 1.3175 & 1.21 & -0.0382 \\
\hline Peromyscus_megalops & 1.46 & 68.6 & 0.1644 & 1.8363 & 1.00 & 0.0721 \\
\hline Peromyscus_melanocarpus & 1.03 & 58.8 & 0.0128 & 1.7694 & 0.77 & 0.0059 \\
\hline Peromyscus_melanophrys & 0.94 & 45 & -0.0269 & 1.6532 & 0.82 & -0.0136 \\
\hline Peromyscus_melanotis & 0.63 & 91 & -0.2007 & 1.9590 & 0.37 & -0.0806 \\
\hline Peromyscus_mexicanus & 1.325 & 49.975 & 0.1222 & 1.6988 & 1.09 & 0.0596 \\
\hline Peromyscus_polionotus & 0.77 & 13.66 & -0.1135 & 1.1355 & 1.35 & -0.0957 \\
\hline Peromyscus_truei & 1.055 & 28.675 & 0.0233 & 1.4575 & 1.20 & 0.0140 \\
\hline Petaurista_elegans & 8.35 & 924 & 0.9217 & 2.9657 & 1.25 & 0.2106 \\
\hline Petaurista_petaurista & 12.32 & 2023 & 1.0906 & 3.3060 & 1.17 & 0.2149 \\
\hline Phyllotis_darwini & 0.92 & 43.9 & -0.0362 & 1.6425 & 0.82 & -0.0185 \\
\hline
\end{tabular}




\begin{tabular}{|c|c|c|c|c|c|c|}
\hline Podomys_floridanus & 1.24 & 30.385 & 0.0934 & 1.4827 & 1.37 & 0.0548 \\
\hline Pogonomys_macrourus & 1.725 & 73.9 & 0.2368 & 1.8686 & 1.13 & 0.1014 \\
\hline Pogonomys_sylvestris & 1.425 & 41.2 & 0.1538 & 1.6149 & 1.31 & 0.0803 \\
\hline Praomys_morio & 1.135 & 46.5 & 0.0550 & 1.6675 & 0.97 & 0.0275 \\
\hline Praomys_tullbergi & 1.155 & 37.2 & 0.0626 & 1.5705 & 1.13 & 0.0339 \\
\hline Proechimys_cuvieri & 3.28 & 397.5 & 0.5159 & 2.5993 & 0.80 & 0.1410 \\
\hline Proechimys_goeldii & 2.62 & 204 & 0.4183 & 2.3096 & 0.95 & 0.1343 \\
\hline Proechimys_guyannensis & 2.31 & 203 & 0.3636 & 2.3075 & 0.84 & 0.1169 \\
\hline Proechimys_longicaudatus & 2.78 & 240 & 0.4440 & 2.3802 & 0.92 & 0.1368 \\
\hline Proechimys_oris & 2.41 & 204 & 0.3820 & 2.3096 & 0.87 & 0.1226 \\
\hline Proechimys_semispinosus & 6.87 & 544.75 & 0.8370 & 2.7362 & 1.40 & 0.2133 \\
\hline Protoxerus_aubinnii & 8.43 & 525 & 0.9258 & 2.7202 & 1.76 & 0.2379 \\
\hline Protoxerus_stangeri & 10.88 & 543 & 1.0366 & 2.7348 & 2.22 & 0.2644 \\
\hline Pseudomys_australis & 1.455 & 50 & 0.1629 & 1.6990 & 1.20 & 0.0794 \\
\hline Pseudomys_hermannsburgensis & 1.08 & 67 & 0.0334 & 1.8261 & 0.75 & 0.0148 \\
\hline Pteromys_volans & 1.92 & 58.3 & 0.2833 & 1.7657 & 1.44 & 0.1310 \\
\hline Pteromyscus_pulverulentus & 3.55 & 400 & 0.5502 & 2.6021 & 0.87 & 0.1502 \\
\hline Rattus_colletti & 1.43 & 76.3 & 0.1553 & 1.8825 & 0.92 & 0.0658 \\
\hline Rattus_exulans & 1.185 & 60.3 & 0.0737 & 1.7803 & 0.87 & 0.0337 \\
\hline Rattus_fuscipes & 1.75 & 105.75 & 0.2430 & 2.0243 & 0.93 & 0.0933 \\
\hline Rattus_leucopus & 1.78 & 96.7 & 0.2504 & 1.9854 & 1.00 & 0.0987 \\
\hline Rattus_lutreolus & 1.935 & 92.7 & 0.2867 & 1.9671 & 1.11 & 0.1145 \\
\hline Rattus_nitidus & 1.7 & 85.95 & 0.2304 & 1.9342 & 1.02 & 0.0941 \\
\hline Rattus_norvegicus & 5.165 & 317.6 & 0.7131 & 2.5019 & 1.44 & 0.2053 \\
\hline Rattus_rattus & 1.79 & 118.6 & 0.2529 & 2.0741 & 0.89 & 0.0939 \\
\hline Rattus_sordidus & 1.62 & 93.735 & 0.2095 & 1.9719 & 0.92 & 0.0834 \\
\hline Rattus_tunneyi & 1.485 & 77.1 & 0.1717 & 1.8871 & 0.95 & 0.0726 \\
\hline Ratufa_affinis & 10.145 & 982.5 & 1.0063 & 2.9923 & 1.47 & 0.2271 \\
\hline Ratufa_bicolor & 11.305 & 1320 & 1.0533 & 3.1206 & 1.38 & 0.2245 \\
\hline Ratufa_indica & 11.4 & 1935 & 1.0569 & 3.2867 & 1.11 & 0.2099 \\
\hline Reithrodontomys_megalotis & 0.695 & 10.7 & -0.1580 & 1.0294 & 1.41 & -0.1522 \\
\hline Rhabdomys_pumilio & 0.495 & 41.005 & -0.3054 & 1.6128 & 0.46 & -0.1597 \\
\hline Rhinosciurus_laticaudatus & 4.28 & 240 & 0.6314 & 2.3802 & 1.41 & 0.1945 \\
\hline Rhipidomys_mastacalis & 1.7 & 100 & 0.2304 & 2.0000 & 0.93 & 0.0900 \\
\hline Saccostomus_campestris & 0.82 & 49.35 & -0.0862 & 1.6933 & 0.68 & -0.0422 \\
\hline Sciurus_aureogaster & 7.81 & 595 & 0.8927 & 2.7745 & 1.51 & 0.2233 \\
\hline Sciurus_carolinensis & 7.585 & 538.835 & 0.8800 & 2.7315 & 1.56 & 0.2248 \\
\hline Sciurus_granatensis & 6.205 & 400 & 0.7927 & 2.6021 & 1.52 & 0.2164 \\
\hline Sciurus_niger & 8.61 & 662.86 & 0.9350 & 2.8214 & 1.57 & 0.2286 \\
\hline Sciurus_vulgaris & 5.89 & 344.2 & 0.7701 & 2.5368 & 1.57 & 0.2176 \\
\hline Sigmodon_hispidus & 1.21 & 93.7 & 0.0828 & 1.9717 & 0.69 & 0.0329 \\
\hline
\end{tabular}




\begin{tabular}{|c|c|c|c|c|c|c|}
\hline Spalacopus_cyanus & 1.875 & 93 & 0.2730 & 1.9685 & 1.07 & 0.1089 \\
\hline Spermophilopsis_leptodactylus & 6.18 & 495 & 0.7910 & 2.6946 & 1.33 & 0.2059 \\
\hline Spermophilus_beecheyi & 5.415 & 587.5 & 0.7336 & 2.7690 & 1.06 & 0.1840 \\
\hline Spermophilus_beldingi & 3.575 & 262.9 & 0.5533 & 2.4198 & 1.12 & 0.1667 \\
\hline Spermophilus_columbianus & 3.915 & 470.5 & 0.5927 & 2.6726 & 0.87 & 0.1560 \\
\hline Spermophilus franklinii & 4.115 & 455.5 & 0.6144 & 2.6585 & 0.93 & 0.1629 \\
\hline Spermophilus_lateralis & 3.405 & 187.9 & 0.5321 & 2.2739 & 1.29 & 0.1744 \\
\hline Spermophilus_parryii & 5.49 & 754.16 & 0.7396 & 2.8775 & 0.93 & 0.1760 \\
\hline Spermophilus_richardsonii & 3.565 & 329.835 & 0.5521 & 2.5183 & 0.97 & 0.1575 \\
\hline Spermophilus_tereticaudus & 2.115 & 156 & 0.3253 & 2.1931 & 0.90 & 0.1120 \\
\hline Spermophilus_townsendii & 2.355 & 199 & 0.3720 & 2.2989 & 0.87 & 0.1202 \\
\hline Spermophilus_tridecemlineatus & 2.7 & 165.7 & 0.4314 & 2.2193 & 1.10 & 0.1462 \\
\hline Spermophilus_undulatus & 5.135 & 725.3 & 0.7105 & 2.8605 & 0.89 & 0.1705 \\
\hline Sphiggurus_villosus & 12.35 & 1250 & 1.0917 & 3.0969 & 1.55 & 0.2351 \\
\hline Stenomys_niobe & 1.21 & 44.75 & 0.0828 & 1.6508 & 1.06 & 0.0420 \\
\hline Sundamys_muelleri & 3.5 & 311.6 & 0.5441 & 2.4936 & 0.99 & 0.1573 \\
\hline Synaptomys_cooperi & 0.885 & 23.8 & -0.0531 & 1.3766 & 1.12 & -0.0344 \\
\hline Tachyoryctes_splendens & 2.175 & 234 & 0.3375 & 2.3692 & 0.73 & 0.1046 \\
\hline Tamias_amoenus & 1.685 & 50.8 & 0.2266 & 1.7059 & 1.37 & 0.1098 \\
\hline Tamias_dorsalis & 2.275 & 62.2 & 0.3570 & 1.7938 & 1.65 & 0.1616 \\
\hline Tamias_minimus & 1.895 & 45.3 & 0.2776 & 1.6561 & 1.65 & 0.1401 \\
\hline Tamias_palmeri & 2.285 & 60.8 & 0.3589 & 1.7839 & 1.68 & 0.1637 \\
\hline Tamias_panamintinus & 2.125 & 51.2 & 0.3274 & 1.7093 & 1.72 & 0.1582 \\
\hline Tamias_quadrimaculatus & 2.455 & 82.3 & 0.3901 & 1.9154 & 1.51 & 0.1615 \\
\hline Tamias_quadrivittatus & 1.995 & 62.3 & 0.2999 & 1.7945 & 1.44 & 0.1357 \\
\hline Tamias_speciosus & 2.155 & 59.9 & 0.3334 & 1.7774 & 1.60 & 0.1528 \\
\hline Tamias_striatus & 2.465 & 94.3 & 0.3918 & 1.9745 & 1.40 & 0.1556 \\
\hline Tamias_townsendii & 2.735 & 89.4 & 0.4370 & 1.9513 & 1.60 & 0.1764 \\
\hline Tamiasciurus_hudsonicus & 4.125 & 188.9 & 0.6154 & 2.2762 & 1.56 & 0.2015 \\
\hline Tamiops_macclellandi & 2.245 & 39 & 0.3512 & 1.5911 & 2.14 & 0.1871 \\
\hline Tatera_afra & 1.855 & 65 & 0.2683 & 1.8129 & 1.31 & 0.1197 \\
\hline Tatera_brantsii & 1.855 & 91.7 & 0.2683 & 1.9624 & 1.07 & 0.1075 \\
\hline Tatera_indica & 2.135 & 139.7 & 0.3294 & 2.1452 & 0.96 & 0.1169 \\
\hline Tatera_leucogaster & 0.88 & 51 & -0.0555 & 1.7076 & 0.72 & -0.0269 \\
\hline Thomomys_bottae & 1.735 & 151.825 & 0.2393 & 2.1813 & 0.75 & 0.0830 \\
\hline Thomomys_talpoides & 1.61 & 113.175 & 0.2068 & 2.0538 & 0.82 & 0.0779 \\
\hline Thrichomys_apereoides & 3.15 & 218 & 0.4983 & 2.3385 & 1.10 & 0.1573 \\
\hline Thrichomys_inermis & 2.64 & 200 & 0.4216 & 2.3010 & 0.97 & 0.1360 \\
\hline Thryonomys_gregorianus & 13.51 & 3500 & 1.1307 & 3.5441 & 0.93 & 0.2027 \\
\hline Thryonomys_swinderianus & 13.575 & 1625 & 1.1327 & 3.2109 & 1.46 & 0.2323 \\
\hline Toromys_grandis & 4.33 & 586 & 0.6365 & 2.7679 & 0.85 & 0.1597 \\
\hline
\end{tabular}




\begin{tabular}{|l|r|r|r|r|r|r|}
\hline Trinomys_albispinus & 2.1305 & 197.27 & 0.3285 & 2.2951 & 0.79 & 0.1063 \\
\hline Trinomys_dimidiatus & 2.8 & 200.76 & 0.4472 & 2.3027 & 1.02 & 0.1441 \\
\hline Trinomys_eliasi & 2.94 & 195.75 & 0.4683 & 2.2917 & 1.09 & 0.1519 \\
\hline Trinomys_iheringi & 3.3 & 234 & 0.5185 & 2.3692 & 1.10 & 0.1608 \\
\hline Trinomys_minor & 2.91 & 171.8 & 0.4639 & 2.2350 & 1.16 & 0.1557 \\
\hline Trinomys_paratus & 2.88 & 242.5 & 0.4594 & 2.3847 & 0.94 & 0.1412 \\
\hline Trinomys_setosus & 2.772 & 258.5 & 0.4428 & 2.4125 & 0.87 & 0.1339 \\
\hline Trinomys_yonenagae & 2.89 & 127.7 & 0.4609 & 2.1062 & 1.38 & 0.1677 \\
\hline Tscherskia_triton & 1.585 & 25 & 0.2000 & 1.3979 & 1.96 & 0.1271 \\
\hline Tympanoctomys_barrerae & 1.9684 & 82 & 0.2941 & 1.9138 & 1.21 & 0.1219 \\
\hline Uranomys_ruddi & 1.065 & 33.6 & 0.0273 & 1.5263 & 1.11 & 0.0154 \\
\hline Wiedomys_pyrrhorhinos & 1.05 & 65 & 0.0212 & 1.8129 & 0.74 & 0.0095 \\
\hline Xerus_erythropus & 6.66 & 612.45 & 0.8235 & 2.7871 & 1.27 & 0.2047 \\
\hline Xerus_inauris & 7.19 & 519 & 0.8567 & 2.7152 & 1.51 & 0.2207 \\
\hline Xerus_rutilus & 5.385 & 317.5 & 0.7312 & 2.5017 & 1.51 & 0.2105 \\
\hline Zapus_hudsonius & 0.785 & 17.9 & -0.1051 & 1.2529 & 1.18 & -0.0775 \\
\hline Zapus_princeps & 0.795 & 24.5 & -0.0996 & 1.3892 & 0.99 & -0.0638 \\
\hline Zygogeomys_trichopus & 3.88 & 545 & 0.5888 & 2.7364 & 0.79 & 0.1501 \\
\hline
\end{tabular}


Anexo VIII - Dados categóricos por espécie do quoeficiente de encefalização (QE_Cat: $0=$ abaixo do esperado; 1 = esperado; 2 = acima do esperado), Uso do habitat (hábito: 1 = terrestre; 2 = semi-fossorial; 3 = fossorial; $4=$ subterrâneo; $5=$ semi-aquático; 6 = arborícola), Tipo de habitat (Habitat: 1 = Florestado; 2 = misto; 3 = aberto), Tipo de dieta (Dieta: $1=$ animal; $2=$ omnivoria; $3=$ herbivoria pobre; $4=$ herbivoria rica; $5=$ herbivoria generalista), Desenvolvimento do neonato (Neonato: $1=$ altricial; 2 = precocial), Tipo de socialidade (Social: 1 = não-social; $2=$ semi-social; 3 = social), atividade temporal (atividade: $1=$ noturna; $2=$ quetameral; 3 = diurna).

\begin{tabular}{|c|c|c|c|c|c|c|c|}
\hline Espécies & QE_Cat & Hábito & Habitat & Dieta & Neonato & Social & Atividade \\
\hline Acomys_cahirinus & 0 & 1 & 3 & 2 & 2 & 3 & 1 \\
\hline Acomys_wilsoni & 0 & 1 & 3 & 2 & 2 & 3 & 1 \\
\hline Aconaemys_porteri & 0 & 2 & 3 & 5 & 2 & 3 & 1 \\
\hline Aconaemys_sagei & 0 & 2 & 3 & 5 & 2 & 3 & 1 \\
\hline Aeromys_tephromelas & 2 & 6 & 1 & 2 & 1 & 2 & 1 \\
\hline Aethomys_chrysophilus & 0 & 1 & 3 & 5 & 1 & 3 & 1 \\
\hline Aethomys_hindei & 0 & 1 & 3 & 5 & 1 & 1 & 1 \\
\hline Aethomys_namaquensis & 0 & 1 & 3 & 5 & 1 & 3 & 1 \\
\hline Agouti_paca & 2 & 1 & 1 & 4 & 2 & 1 & 1 \\
\hline Akodon_azarae & 0 & 3 & 3 & 1 & 1 & 3 & 1 \\
\hline Allactaga_sibirica & 2 & 2 & 3 & 1 & 1 & 1 & 1 \\
\hline Ammospermophilus_harrisii & 1 & 2 & 3 & 2 & 1 & 1 & 3 \\
\hline Ammospermophilus_leucurus & 2 & 2 & 3 & 2 & 1 & 1 & 3 \\
\hline Ammospermophilus_nelsoni & 2 & 2 & 3 & 2 & 1 & 3 & 3 \\
\hline Aplodontia_rufa & 2 & 3 & 1 & 5 & 1 & 1 & 2 \\
\hline Apodemus_agrarius & 0 & 2 & 2 & 2 & 1 & 2 & 3 \\
\hline Apodemus flavicollis & 1 & 2 & 2 & 2 & 1 & 3 & 1 \\
\hline Apodemus_sylvaticus & 2 & 2 & 2 & 2 & 1 & 2 & 2 \\
\hline Arvicanthis_niloticus & 1 & 2 & 3 & 2 & 1 & 3 & 3 \\
\hline Arvicola_terrestris & 0 & 5 & 3 & 5 & 1 & 2 & 2 \\
\hline Atherurus_africanus & 2 & 1 & 1 & 2 & 2 & 3 & 1 \\
\hline Bathyergus_janetta & 0 & 4 & 3 & 4 & 1 & 1 & 2 \\
\hline Bathyergus_suillus & 0 & 4 & 3 & 4 & 1 & 1 & 2 \\
\hline Beamys_hindei & 0 & 1 & 1 & 5 & 1 & 1 & 1 \\
\hline Berylmys_bowersi & 2 & 1 & 2 & 2 & 1 & 2 & 1 \\
\hline Callistomys_pictus & 0 & 6 & 1 & 4 & 2 & 1 & 1 \\
\hline Callosciurus_caniceps & 2 & 6 & 1 & 2 & 1 & 2 & 3 \\
\hline Callosciurus_nigrovittatus & 2 & 6 & 1 & 2 & 1 & 2 & 3 \\
\hline Callosciurus_notatus & 2 & 6 & 1 & 2 & 1 & 2 & 3 \\
\hline Callosciurus_prevostii & 2 & 6 & 1 & 2 & 1 & 2 & 3 \\
\hline Calomys_callosus & 0 & 1 & 3 & 2 & 1 & 1 & 1 \\
\hline Capromys_pilorides & 0 & 6 & 1 & 5 & 2 & 3 & 3 \\
\hline
\end{tabular}




\begin{tabular}{|c|c|c|c|c|c|c|c|}
\hline Carterodon_sulcidens & 0 & 3 & 3 & 5 & 2 & 2 & 1 \\
\hline Castor_canadensis & 1 & 5 & 2 & 5 & 2 & 2 & 1 \\
\hline Castor fiber & 1 & 5 & 2 & 5 & 2 & 2 & 1 \\
\hline Cavia aperea & 2 & 1 & 3 & 3 & 2 & 3 & 3 \\
\hline Cavia_pamparum & 1 & 1 & 3 & 3 & 2 & 3 & 2 \\
\hline Cavia_porcellus & 1 & 1 & 3 & 3 & 2 & 3 & 2 \\
\hline Chaetodipus_baileyi & 2 & 2 & 3 & 2 & 1 & 1 & 1 \\
\hline Chaetodipus_californicus & 0 & 2 & 2 & 4 & 1 & 1 & 1 \\
\hline Chaetodipus_fallax & 0 & 2 & 2 & 4 & 1 & 1 & 1 \\
\hline Chaetodipus_formosus & 2 & 2 & 3 & 4 & 1 & 1 & 1 \\
\hline Chaetodipus_hispidus & 1 & 2 & 3 & 4 & 1 & 1 & 1 \\
\hline Chaetodipus_penicillatus & 2 & 2 & 3 & 4 & 1 & 1 & 1 \\
\hline Chaetomys_subspinosus & 2 & 6 & 1 & 5 & 2 & 1 & 1 \\
\hline Chinchilla_lanigera & 2 & 1 & 3 & 5 & 2 & 3 & 1 \\
\hline Chiropodomys_gliroides & 2 & 6 & 1 & 5 & 1 & 1 & 1 \\
\hline Clethrionomys_gapperi & 2 & 1 & 2 & 2 & 1 & 2 & 1 \\
\hline Clethrionomys_glareolus & 2 & 1 & 2 & 2 & 1 & 2 & 1 \\
\hline Clethrionomys_rufocanus & 0 & 1 & 2 & 2 & 1 & 2 & 1 \\
\hline Clethrionomys_rutilus & 2 & 1 & 2 & 2 & 1 & 2 & 2 \\
\hline Clyomys_bishopi & 0 & 3 & 3 & 5 & 2 & 3 & 1 \\
\hline Cricetomys_gambianus & 1 & 1 & 2 & 2 & 1 & 1 & 1 \\
\hline Cricetulus_barabensis & 0 & 2 & 3 & 5 & 1 & 1 & 1 \\
\hline Cricetus_cricetus & 0 & 2 & 3 & 2 & 1 & 1 & 2 \\
\hline Cryptomys_hottentotus & 0 & 4 & 3 & 4 & 2 & 3 & 2 \\
\hline Ctenomys_argentinus & 0 & 4 & 3 & 5 & 2 & 1 & 2 \\
\hline Ctenomys_australis & 0 & 4 & 3 & 5 & 2 & 1 & 2 \\
\hline Ctenomys_azarae & 0 & 4 & 3 & 5 & 2 & 1 & 2 \\
\hline Ctenomys_boliviensis & 0 & 4 & 3 & 5 & 2 & 1 & 1 \\
\hline Ctenomys_bonettoi & 0 & 4 & 3 & 5 & 2 & 1 & 2 \\
\hline Ctenomys_chasiquensis & 0 & 4 & 3 & 5 & 2 & 1 & 2 \\
\hline Ctenomys_dorbignyi & 0 & 4 & 3 & 5 & 2 & 1 & 2 \\
\hline Ctenomys_emilianus & 0 & 4 & 3 & 5 & 2 & 1 & 2 \\
\hline Ctenomys_flamarioni & 0 & 4 & 3 & 5 & 2 & 1 & 2 \\
\hline Ctenomys_fulvus & 0 & 4 & 3 & 5 & 2 & 1 & 2 \\
\hline Ctenomys_haigi & 0 & 4 & 3 & 5 & 2 & 1 & 2 \\
\hline Ctenomys_lami & 0 & 4 & 3 & 5 & 2 & 1 & 2 \\
\hline Ctenomys_latro & 0 & 4 & 3 & 5 & 2 & 1 & 2 \\
\hline Ctenomys_leucodon & 1 & 4 & 3 & 5 & 2 & 1 & 1 \\
\hline Ctenomys_magellanicus & 1 & 4 & 3 & 5 & 2 & 1 & 2 \\
\hline Ctenomys_maulinus & 0 & 4 & 3 & 5 & 2 & 1 & 2 \\
\hline Ctenomys_mendocinus & 0 & 4 & 3 & 5 & 2 & 1 & 2 \\
\hline
\end{tabular}




\begin{tabular}{|c|c|c|c|c|c|c|c|}
\hline Ctenomys_minutus & 0 & 4 & 3 & 5 & 2 & 1 & 2 \\
\hline Ctenomys_occultus & 1 & 4 & 3 & 5 & 2 & 1 & 2 \\
\hline Ctenomys_opimus & 1 & 4 & 3 & 5 & 2 & 1 & 3 \\
\hline Ctenomys perrensis & 1 & 4 & 3 & 5 & 2 & 1 & 2 \\
\hline Ctenomys_porteousi & 0 & 4 & 3 & 5 & 2 & 1 & 2 \\
\hline Ctenomys_pundti & 0 & 4 & 3 & 5 & 2 & 1 & 2 \\
\hline Ctenomys_rionegrensis & 0 & 4 & 3 & 5 & 2 & 1 & 2 \\
\hline Ctenomys_roigi & 1 & 4 & 3 & 5 & 2 & 1 & 2 \\
\hline Ctenomys_sociabilis & 0 & 4 & 3 & 5 & 2 & 3 & 1 \\
\hline Ctenomys_talarum & 0 & 4 & 3 & 5 & 2 & 1 & 3 \\
\hline Ctenomys_torquatus & 0 & 4 & 3 & 5 & 2 & 1 & 2 \\
\hline Ctenomys_tuconax & 0 & 4 & 3 & 5 & 2 & 1 & 2 \\
\hline Ctenomys_tucumanus & 0 & 4 & 3 & 5 & 2 & 1 & 2 \\
\hline Cynomys_gunnisoni & 0 & 2 & 2 & 2 & 1 & 3 & 3 \\
\hline Cynomys_leucurus & 0 & 2 & 3 & 5 & 1 & 3 & 3 \\
\hline Cynomys_ludovicianus & 1 & 2 & 3 & 3 & 1 & 3 & 3 \\
\hline Dactylomys_dactylinus & 1 & 6 & 1 & 3 & 2 & 2 & 1 \\
\hline Dasyprocta_leporina & 2 & 1 & 1 & 4 & 2 & 2 & 3 \\
\hline Dasyprocta_prymnolopha & 2 & 1 & 2 & 4 & 2 & 2 & 3 \\
\hline Dasyprocta_punctata & 2 & 1 & 1 & 4 & 2 & 2 & 3 \\
\hline Dendromus_mystacalis & 1 & 6 & 1 & 2 & 1 & 1 & 1 \\
\hline Dicrostonyx_groenlandicus & 0 & 2 & 3 & 5 & 1 & 2 & 2 \\
\hline Dicrostonyx_torquatus & 0 & 2 & 3 & 5 & 1 & 2 & 2 \\
\hline Dinomys_branickii & 0 & 1 & 1 & 5 & 2 & 2 & 1 \\
\hline Dipodomys_agilis & 2 & 2 & 3 & 4 & 1 & 1 & 1 \\
\hline Dipodomys_deserti & 1 & 2 & 3 & 5 & 1 & 1 & 1 \\
\hline Dipodomys_heermanni & 2 & 2 & 3 & 2 & 1 & 1 & 1 \\
\hline Dipodomys_merriami & 2 & 2 & 3 & 4 & 1 & 1 & 1 \\
\hline Dipodomys_microps & 2 & 2 & 3 & 5 & 1 & 1 & 1 \\
\hline Dipodomys_ordii & 2 & 2 & 3 & 4 & 1 & 1 & 1 \\
\hline Dipodomys_panamintinus & 1 & 2 & 3 & 4 & 1 & 1 & 1 \\
\hline Dipodomys_spectabilis & 1 & 2 & 3 & 4 & 1 & 1 & 1 \\
\hline Dolichotis_patagonum & 2 & 1 & 3 & 5 & 2 & 3 & 1 \\
\hline Dremomys_rufigenis & 2 & 6 & 1 & 2 & 1 & 1 & 3 \\
\hline Echimys_chrysurus & 0 & 6 & 1 & 4 & 2 & 2 & 1 \\
\hline Erethizon_dorsatum & 2 & 6 & 2 & 5 & 2 & 1 & 1 \\
\hline Euryzygomatomys_spinosus & 1 & 3 & 3 & 5 & 2 & 2 & 1 \\
\hline Fukomys_anselli & 0 & 4 & 3 & 4 & 2 & 3 & 2 \\
\hline Fukomys_mechowi & 0 & 4 & 3 & 4 & 2 & 3 & 2 \\
\hline Funambulus_pennantii & 2 & 6 & 2 & 2 & 1 & 3 & 3 \\
\hline Funisciurus_anerythrus & 2 & 6 & 1 & 2 & 1 & 2 & 2 \\
\hline
\end{tabular}




\begin{tabular}{|c|c|c|c|c|c|c|c|}
\hline Funisciurus_carruthersi & 2 & 6 & 1 & 2 & 1 & 2 & 3 \\
\hline Funisciurus_lemniscatus & 2 & 6 & 1 & 2 & 1 & 2 & 2 \\
\hline Funisciurus_pyrropus & 2 & 6 & 1 & 2 & 1 & 2 & 3 \\
\hline Funisciurus_substriatus & 2 & 6 & 1 & 2 & 1 & 2 & 2 \\
\hline Galea_musteloides & 0 & 1 & 3 & 3 & 2 & 3 & 3 \\
\hline Galea_spixii & 0 & 1 & 3 & 3 & 2 & 3 & 3 \\
\hline Geocapromys_ingrahami & 0 & 6 & 1 & 5 & 2 & 3 & 1 \\
\hline Geomys_bursarius & 0 & 4 & 3 & 5 & 1 & 1 & 2 \\
\hline Geomys_pinetis & 0 & 4 & 2 & 5 & 1 & 1 & 2 \\
\hline Georychus_capensis & 0 & 4 & 3 & 4 & 1 & 1 & 3 \\
\hline Gerbillurus_paeba & 2 & 2 & 3 & 4 & 1 & 1 & 1 \\
\hline Gerbillus_campestris & 2 & 2 & 3 & 2 & 1 & 3 & 1 \\
\hline Gerbillus_dasyurus & 2 & 2 & 3 & 4 & 1 & 1 & 1 \\
\hline Gerbillus_gleadowi & 2 & 2 & 3 & 2 & 1 & 3 & 1 \\
\hline Gerbillus_pyramidum & 1 & 2 & 3 & 2 & 1 & 3 & 1 \\
\hline Glaucomys_sabrinus & 2 & 6 & 1 & 2 & 1 & 3 & 1 \\
\hline Glaucomys_volans & 2 & 6 & 1 & 2 & 1 & 3 & 1 \\
\hline Glis_glis & 0 & 6 & 1 & 2 & 1 & 1 & 1 \\
\hline Grammomys_cometes & 0 & 6 & 3 & 2 & 1 & 1 & 1 \\
\hline Grammomys_dolichurus & 2 & 6 & 1 & 2 & 1 & 1 & 1 \\
\hline Grammomys_rutilans & 2 & 1 & 1 & 2 & 1 & 1 & 1 \\
\hline Graphiurus_murinus & 1 & 6 & 1 & 2 & 1 & 1 & 1 \\
\hline Heliophobius_argenteocinereus & 0 & 4 & 3 & 4 & 1 & 1 & 2 \\
\hline Heliosciurus_gambianus & 2 & 6 & 2 & 2 & 1 & 2 & 3 \\
\hline Heliosciurus_rufobrachium & 2 & 6 & 1 & 2 & 1 & 2 & 3 \\
\hline Heliosciurus_ruwenzorii & 2 & 6 & 1 & 2 & 1 & 2 & 3 \\
\hline Heterocephalus_glaber & 0 & 4 & 3 & 4 & 1 & 4 & 2 \\
\hline Heteromys_desmarestianus & 1 & 2 & 1 & 2 & 1 & 2 & 1 \\
\hline Holochilus_chacarius & 0 & 5 & 2 & 2 & 1 & 1 & 1 \\
\hline Holochilus_sciureus & 0 & 5 & 2 & 2 & 1 & 1 & 1 \\
\hline Hoplomys_gymnurus & 2 & 1 & 1 & 5 & 2 & 2 & 1 \\
\hline Hybomys_trivirgatus & 2 & 1 & 1 & 1 & 1 & 3 & 2 \\
\hline Hydrochaeris_hydrochaeris & 2 & 5 & 2 & 3 & 2 & 3 & 2 \\
\hline Hydromys_chrysogaster & 0 & 5 & 3 & 1 & 1 & 1 & 3 \\
\hline Hylopetes_spadiceus & 2 & 6 & 1 & 2 & 1 & 1 & 1 \\
\hline Hystrix_africaeaustralis & 0 & 1 & 2 & 2 & 2 & 3 & 1 \\
\hline Hystrix_cristata & 2 & 1 & 2 & 2 & 2 & 3 & 1 \\
\hline Iomys_horsfieldii & 2 & 6 & 1 & 2 & 1 & 2 & 1 \\
\hline Isothrix_bistriata & 0 & 6 & 1 & 4 & 2 & 2 & 1 \\
\hline Isthmomys_pirrensis & 0 & 1 & 1 & 2 & 1 & 1 & 1 \\
\hline Jaculus_jaculus & 2 & 2 & 3 & 2 & 1 & 1 & 1 \\
\hline
\end{tabular}




\begin{tabular}{|l|r|r|r|r|r|r|r|}
\hline Jaculus_orientalis & 2 & 2 & 3 & 5 & 1 & 2 & 1 \\
\hline Kannabateomys_amblyonyx & 1 & 6 & 1 & 3 & 2 & 2 & 1 \\
\hline Kerodon_rupestris & 1 & 1 & 3 & 3 & 2 & 3 & 2 \\
\hline Lagidium_viscacia & 2 & 1 & 3 & 5 & 2 & 3 & 3 \\
\hline Lagostomus_maximus & 1 & 2 & 3 & 3 & 2 & 3 & 1 \\
\hline Lemmus_lemmus & 0 & 2 & 3 & 5 & 1 & 2 & 2 \\
\hline Lemmus_sibiricus & 1 & 2 & 3 & 5 & 1 & 1 & 2 \\
\hline Lemniscomys_rosalia & 0 & 1 & 2 & 2 & 1 & 1 & 2 \\
\hline Lemniscomys_striatus & 1 & 1 & 2 & 2 & 1 & 1 & 1 \\
\hline Leopoldamys_edwardsi & 2 & 1 & 1 & 2 & 1 & 1 & 1 \\
\hline Leopoldamys_sabanus & 1 & 6 & 1 & 2 & 1 & 1 & 1 \\
\hline Liomys_irroratus & 0 & 2 & 2 & 5 & 1 & 1 & 1 \\
\hline Liomys_pictus & 1 & 2 & 2 & 5 & 1 & 1 & 1 \\
\hline Liomys_salvini & 1 & 2 & 1 & 4 & 1 & 1 & 1 \\
\hline Lonchothrix_emiliae & 0 & 6 & 1 & 5 & 2 & 2 & 1 \\
\hline Lophuromys_flavopunctatus & 1 & 1 & 2 & 2 & 1 & 1 & 3 \\
\hline Lophuromys_sikapusi & 1 & 1 & 2 & 2 & 1 & 1 & 1 \\
\hline Makalata_armata & 0 & 6 & 1 & 4 & 2 & 1 & 1 \\
\hline Malacomys_edwardsi & 1 & 1 & 3 & 2 & 1 & 1 & 1 \\
\hline Malacothrix_typica & 0 & 2 & 2 & 5 & 1 & 1 & 1 \\
\hline Marmota_flaviventris & 0 & 2 & 2 & 5 & 1 & 3 & 3 \\
\hline Marmota_marmota & 2 & 2 & 3 & 5 & 1 & 3 & 3 \\
\hline Marmota_monax & 0 & 2 & 2 & 2 & 1 & 1 & 3 \\
\hline Marmota_sibirica & 2 & 2 & 2 & 5 & 1 & 3 & 3 \\
\hline Massoutiera_mzabi & 1 & 1 & 3 & 5 & 2 & 3 & 3 \\
\hline Mastomys_coucha & 1 & 1 & 3 & 2 & 1 & 3 & 1 \\
\hline Mastomys_natalensis & 0 & 1 & 3 & 2 & 1 & 3 & 1 \\
\hline Maxomys_rajah & 2 & 1 & 1 & 2 & 1 & 1 & 1 \\
\hline Maxomys_surifer & 1 & 1 & 1 & 2 & 1 & 1 & 1 \\
\hline Maxomy_whiteheadi & 1 & 1 & 1 & 2 & 1 & 1 & 1 \\
\hline Megadontomys_thomasi & 1 & 1 & 1 & 2 & 1 & 1 & 1 \\
\hline Melomy_cervinipes & 1 & 6 & 1 & 5 & 1 & 1 & 1 \\
\hline Melomys_levipes & 2 & 1 & 1 & 5 & 1 & 1 & 1 \\
\hline Melomy_rubex & 2 & 1 & 1 & 5 & 1 & 1 & 1 \\
\hline Melomys_rufescens & 2 & 6 & 3 & 5 & 1 & 1 & 1 \\
\hline Meriones_crassus & 0 & 2 & 3 & 5 & 1 & 3 & 1 \\
\hline Meriones_hurrianae & 0 & 2 & 3 & 2 & 1 & 3 & 3 \\
\hline Meriones_libycus & 0 & 2 & 3 & 2 & 1 & 3 & 3 \\
\hline Meriones_shawi & 0 & 2 & 3 & 2 & 1 & 3 & 1 \\
\hline Meriones_unguiculatus & 1 & 1 & 5 & 1 & 3 & 2 \\
\hline Mesembriomys_gouldii & & 2 & 1 & 1 & 1 \\
\hline
\end{tabular}




\begin{tabular}{|l|r|r|r|r|r|r|r|}
\hline Mesocricetus_auratus & 0 & 2 & 3 & 2 & 1 & 1 & 1 \\
\hline Microcavia_australis & 1 & 2 & 3 & 3 & 2 & 2 & 3 \\
\hline Microdipodops_megacephalus & 2 & 2 & 3 & 4 & 1 & 1 & 1 \\
\hline Microdipodops_pallidus & 1 & 2 & 3 & 4 & 1 & 1 & 1 \\
\hline Micromys_minutus & 2 & 1 & 3 & 2 & 1 & 2 & 2 \\
\hline Microtus_agrestis & 2 & 3 & 2 & 5 & 1 & 2 & 2 \\
\hline Microtus_arvalis & 1 & 3 & 2 & 5 & 1 & 1 & 1 \\
\hline Microtus_californicus & 1 & 3 & 2 & 5 & 1 & 3 & 1 \\
\hline Microtus_guentheri & 0 & 3 & 2 & 5 & 1 & 1 & 1 \\
\hline Microtus_longicaudus & 0 & 3 & 2 & 5 & 1 & 1 & 1 \\
\hline Microtus_montanus & 1 & 3 & 3 & 5 & 1 & 1 & 1 \\
\hline Microtus_ochrogaster & 0 & 3 & 3 & 5 & 1 & 2 & 2 \\
\hline Microtus_oregoni & 1 & 3 & 1 & 5 & 1 & 2 & 1 \\
\hline Microtus_pennsylvanicus & 1 & 3 & 3 & 5 & 1 & 1 & 2 \\
\hline Microtus_pinetorum & 1 & 3 & 1 & 5 & 1 & 3 & 3 \\
\hline Microtus_townsendii & 1 & 3 & 3 & 5 & 2 & 2 & 1 \\
\hline Microtus_xanthognathus & 0 & 3 & 2 & 5 & 1 & 2 & 2 \\
\hline Mus_booduga & 1 & 1 & 3 & 2 & 1 & 3 & 1 \\
\hline Mus_minutoides & 0 & 1 & 1 & 2 & 1 & 3 & 1 \\
\hline Mus_musculus & 0 & 1 & 1 & 2 & 1 & 3 & 1 \\
\hline Mus_platythrix & 0 & 1 & 1 & 2 & 1 & 3 & 1 \\
\hline Mus_triton & 0 & 1 & 3 & 2 & 1 & 3 & 2 \\
\hline Myocastor_coypus & 0 & 5 & 2 & 5 & 2 & 2 & 1 \\
\hline Myomys_daltoni & 1 & 1 & 2 & 2 & 1 & 1 & 1 \\
\hline Myoprocta_acouchy & 2 & 1 & 1 & 4 & 2 & 2 & 3 \\
\hline Myopus_schisticolor & 0 & 1 & 1 & 5 & 1 & 1 & 2 \\
\hline Mystromys_albicaudatus & 0 & 1 & 3 & 2 & 1 & 2 & 1 \\
\hline Nannospalax_ehrenbergi & 0 & 4 & 3 & 4 & 1 & 1 & 2 \\
\hline Nannospalax_leucodon & 2 & 4 & 3 & 4 & 1 & 1 & 2 \\
\hline Napaeozapus_insignis & 1 & 2 & 1 & 2 & 1 & 2 & 1 \\
\hline Nectomys_squamipes & 0 & 5 & 1 & 2 & 1 & 1 & 1 \\
\hline Neofiber_alleni & 1 & 5 & 1 & 5 & 1 & 2 & 1 \\
\hline Neotoma_albigula & 0 & 1 & 2 & 2 & 1 & 1 & 1 \\
\hline Neotoma_floridana & 1 & 1 & 2 & 2 & 1 & 1 & 1 \\
\hline Neotoma_fuscipes & 2 & 1 & 1 & 5 & 1 & 2 & 1 \\
\hline Neotoma_goldmani & 2 & 1 & 2 & 5 & 1 & 1 & 1 \\
\hline Neotoma_lepida & 0 & 1 & 2 & 5 & 1 & 1 & 1 \\
\hline Neotoma_mexicana & 0 & 1 & 1 & 5 & 1 & 1 & 1 \\
\hline Neotoma_micropus & 0 & 1 & 2 & 5 & 1 & 1 & 1 \\
\hline Neotoma_stephensi & 2 & 3 & 2 & 1 & 1 & 1 \\
\hline Notomys_alexis & & & & & 3 & 1 \\
\hline
\end{tabular}




\begin{tabular}{|c|c|c|c|c|c|c|c|}
\hline Nyctomys_sumichrasti & 1 & 6 & 1 & 5 & 1 & 2 & 1 \\
\hline Ochrotomys_nuttalli & 2 & 6 & 1 & 4 & 1 & 3 & 1 \\
\hline Octodon_degus & 1 & 2 & 3 & 5 & 2 & 3 & 3 \\
\hline Octodontomys_gliroides & 2 & 2 & 3 & 5 & 2 & 2 & 2 \\
\hline Octomys_mimax & 1 & 2 & 3 & 5 & 2 & 1 & 1 \\
\hline Oenomys_hypoxanthus & 0 & 1 & 3 & 2 & 1 & 1 & 2 \\
\hline Oligoryzomys_longicaudatus & 2 & 1 & 2 & 2 & 1 & 1 & 1 \\
\hline Oligoryzomys_nigripes & 0 & 1 & 2 & 2 & 1 & 1 & 1 \\
\hline Ondatra_zibethicus & 0 & 5 & 3 & 5 & 1 & 2 & 2 \\
\hline Onychomys_leucogaster & 1 & 2 & 3 & 1 & 1 & 1 & 1 \\
\hline Onychomys_torridus & 0 & 2 & 3 & 1 & 1 & 1 & 1 \\
\hline Orthogeomys_cherriei & 0 & 4 & 2 & 5 & 1 & 1 & 2 \\
\hline Orthogeomys_heterodus & 0 & 4 & 3 & 5 & 1 & 1 & 2 \\
\hline Orthogeomys_hispidus & 0 & 4 & 2 & 5 & 1 & 1 & 2 \\
\hline Oryzomys_palustris & 1 & 5 & 2 & 2 & 1 & 3 & 1 \\
\hline Otomys_angoniensis & 0 & 1 & 2 & 5 & 2 & 1 & 3 \\
\hline Otomys_irroratus & 0 & 1 & 2 & 5 & 2 & 1 & 3 \\
\hline Ototylomys_phyllotis & 2 & 6 & 1 & 5 & 2 & 1 & 1 \\
\hline Pappogeomys_gymnurus & 0 & 4 & 2 & 5 & 1 & 1 & 2 \\
\hline Paraxerus_cepapi & 1 & 6 & 1 & 2 & 1 & 2 & 3 \\
\hline Paraxerus_poensis & 2 & 6 & 1 & 2 & 1 & 2 & 3 \\
\hline Pectinator_spekei & 0 & 1 & 3 & 5 & 2 & 3 & 3 \\
\hline Pedetes_capensis & 0 & 2 & 3 & 2 & 2 & 2 & 1 \\
\hline Perognathus flavus & 2 & 2 & 3 & 4 & 1 & 1 & 1 \\
\hline Perognathus_longimembris & 2 & 2 & 3 & 4 & 1 & 1 & 1 \\
\hline Perognathus_parvus & 0 & 2 & 3 & 4 & 1 & 1 & 1 \\
\hline Peromyscus_aztecus & 0 & 2 & 2 & 2 & 1 & 2 & 1 \\
\hline Peromyscus_boylii & 2 & 1 & 2 & 2 & 1 & 1 & 1 \\
\hline Peromyscus_californicus & 2 & 6 & 2 & 2 & 1 & 2 & 1 \\
\hline Peromyscus_crinitus & 2 & 1 & 2 & 2 & 1 & 1 & 1 \\
\hline Peromyscus_eremicus & 2 & 1 & 2 & 2 & 1 & 1 & 1 \\
\hline Peromyscus_gossypinus & 2 & 1 & 2 & 2 & 1 & 1 & 1 \\
\hline Peromyscus_guatemalensis & 1 & 1 & 2 & 2 & 1 & 1 & 1 \\
\hline Peromyscus_leucopus & 2 & 1 & 3 & 2 & 1 & 1 & 1 \\
\hline Peromyscus_maniculatus & 2 & 1 & 2 & 2 & 1 & 1 & 1 \\
\hline Peromyscus_megalops & 1 & 1 & 2 & 2 & 1 & 1 & 1 \\
\hline Peromyscus_melanocarpus & 0 & 1 & 2 & 2 & 1 & 1 & 1 \\
\hline Peromyscus_melanophrys & 0 & 6 & 2 & 2 & 1 & 1 & 1 \\
\hline Peromyscus_melanotis & 0 & 1 & 2 & 2 & 1 & 1 & 1 \\
\hline Peromyscus_mexicanus & 1 & 1 & 2 & 2 & 1 & 1 & 1 \\
\hline Peromyscus_polionotus & 2 & 1 & 2 & 2 & 1 & 2 & 1 \\
\hline
\end{tabular}




\begin{tabular}{|l|r|r|r|r|r|r|r|}
\hline Peromyscus_truei & 2 & 1 & 2 & 2 & 1 & 1 & 1 \\
\hline Petaurista_elegans & 2 & 6 & 1 & 2 & 1 & 2 & 1 \\
\hline Petaurista_petaurista & 2 & 6 & 1 & 5 & 1 & 2 & 1 \\
\hline Phyllotis_darwini & 0 & 1 & 3 & 5 & 1 & 1 & 1 \\
\hline Podomys_floridanus & 2 & 1 & 3 & 2 & 1 & 1 & 1 \\
\hline Pogonomys_macrourus & 2 & 6 & 1 & 2 & 1 & 1 & 1 \\
\hline Pogonomy_sylvestris & 2 & 6 & 1 & 2 & 1 & 1 & 1 \\
\hline Praomys_morio & 1 & 6 & 1 & 2 & 1 & 2 & 1 \\
\hline Praomys_tullbergi & 2 & 6 & 1 & 2 & 1 & 2 & 1 \\
\hline Proechimys_cuvieri & 0 & 1 & 1 & 5 & 2 & 1 & 1 \\
\hline Proechimy_goeldii & 1 & 1 & 1 & 5 & 2 & 1 & 1 \\
\hline Proechimys_guyannensis & 0 & 1 & 1 & 5 & 2 & 1 & 1 \\
\hline Proechimys_longicaudatus & 1 & 1 & 1 & 5 & 2 & 1 & 1 \\
\hline Proechimys_oris & 0 & 1 & 1 & 5 & 2 & 1 & 1 \\
\hline Proechimy_semispinosus & 2 & 1 & 1 & 5 & 2 & 1 & 1 \\
\hline Protoxerus_aubinnii & 2 & 6 & 1 & 5 & 1 & 1 & 3 \\
\hline Protoxerus_stangeri & 2 & 6 & 1 & 5 & 1 & 1 & 3 \\
\hline Pseudomys_australis & 2 & 2 & 2 & 2 & 1 & 1 & 1 \\
\hline Pseudomys_hermannsburgensis & 0 & 2 & 2 & 2 & 1 & 3 & 1 \\
\hline Pteromys_volans & 2 & 6 & 1 & 2 & 1 & 2 & 1 \\
\hline Pteromyscus_pulverulentus & 0 & 6 & 1 & 5 & 1 & 1 & 1 \\
\hline Rattus_colletti & 1 & 1 & 1 & 2 & 1 & 2 & 1 \\
\hline Rattus_exulans & 0 & 1 & 2 & 2 & 1 & 3 & 1 \\
\hline Rattus_fuscipes & 1 & 1 & 1 & 2 & 1 & 3 & 1 \\
\hline Rattus_leucopus & 1 & 1 & 1 & 2 & 1 & 3 & 1 \\
\hline Rattus_lutreolus & 2 & 1 & 1 & 2 & 1 & 1 & 2 \\
\hline Rattus_nitidus & 1 & 1 & 2 & 2 & 1 & 2 & 1 \\
\hline Rattus_norvegicus & 2 & 1 & 2 & 2 & 1 & 3 & 1 \\
\hline Rattus_rattus & 0 & 1 & 2 & 2 & 1 & 3 & 1 \\
\hline Rattus_sordidus & 1 & 1 & 3 & 2 & 1 & 3 & 1 \\
\hline Rattus_tunneyi & 1 & 1 & 3 & 2 & 1 & 3 & 1 \\
\hline Ratufa_affinis & 2 & 6 & 1 & 2 & 1 & 1 & 3 \\
\hline Ratufa_bicolor & 2 & 6 & 1 & 2 & 1 & 1 & 3 \\
\hline Ratufa_indica & 6 & 1 & 2 & 1 & 1 & 3 \\
\hline Reithrodontomys_megalotis & 2 & 1 & 2 & 2 & 1 & 1 & 1 \\
\hline Rhabdomys_pumilio & 0 & 1 & 2 & 2 & 1 & 1 & 3 \\
\hline Rhinosciurus_laticaudatus & 2 & 6 & 1 & 2 & 1 & 1 & 3 \\
\hline Rhipidomys_mastacalis & 1 & 6 & 1 & 5 & 1 & 1 & 1 \\
\hline Saccostomus_campestris & 0 & 1 & 3 & 2 & 1 & 1 & 1 \\
\hline Sciurus_aureogaster & 2 & 1 & 2 & 1 & 1 & 3 \\
\hline Sciurus_carolinensis & & & & 1 & 2 & 3 \\
\hline
\end{tabular}




\begin{tabular}{|l|r|r|r|r|r|r|r|}
\hline Sciurus_granatensis & 2 & 6 & 1 & 2 & 1 & 2 & 3 \\
\hline Sciurus_niger & 2 & 6 & 1 & 2 & 1 & 1 & 3 \\
\hline Sciurus_vulgaris & 2 & 6 & 1 & 2 & 1 & 2 & 3 \\
\hline Sigmodon_hispidus & 0 & 1 & 3 & 2 & 1 & 1 & 1 \\
\hline Spalacopus_cyanus & 1 & 3 & 3 & 5 & 2 & 3 & 2 \\
\hline Spermophilopsis_leptodactylus & 2 & 2 & 3 & 2 & 1 & 3 & 3 \\
\hline Spermophilus_beecheyi & 1 & 2 & 2 & 2 & 1 & 2 & 3 \\
\hline Spermophilus_beldingi & 2 & 2 & 3 & 2 & 1 & 2 & 3 \\
\hline Spermophilus_columbianus & 0 & 2 & 3 & 5 & 1 & 2 & 3 \\
\hline Spermophilus_franklinii & 1 & 2 & 3 & 2 & 1 & 2 & 3 \\
\hline Spermophilus_lateralis & 2 & 2 & 2 & 2 & 1 & 1 & 3 \\
\hline Spermophilus_parryii & 1 & 2 & 2 & 2 & 1 & 3 & 3 \\
\hline Spermophilus_richardsonii & 1 & 2 & 3 & 2 & 1 & 2 & 3 \\
\hline Spermophilus_tereticaudus & 0 & 2 & 3 & 2 & 1 & 2 & 3 \\
\hline Spermophilus_townsendii & 0 & 2 & 3 & 2 & 1 & 2 & 3 \\
\hline Spermophilus_tridecemlineatus & 2 & 2 & 3 & 2 & 1 & 2 & 3 \\
\hline Spermophilus_undulatus & 0 & 2 & 2 & 2 & 1 & 2 & 3 \\
\hline Sphiggurus_villosus & 2 & 6 & 1 & 5 & 2 & 1 & 1 \\
\hline Stenomys_niobe & 1 & 1 & 3 & 2 & 1 & 1 & 3 \\
\hline Sundamys_muelleri & 1 & 1 & 1 & 2 & 1 & 1 & 1 \\
\hline Synaptomys_cooperi & 2 & 1 & 2 & 5 & 1 & 1 & 2 \\
\hline Tachyoryctes_splendens & 0 & 4 & 3 & 4 & 1 & 1 & 3 \\
\hline Tamias_amoenus & 2 & 2 & 2 & 2 & 1 & 1 & 3 \\
\hline Tamias_dorsalis & 2 & 6 & 2 & 2 & 1 & 2 & 3 \\
\hline Tamias_minimus & 2 & 2 & 2 & 2 & 1 & 1 & 3 \\
\hline Tamias_palmeri & 2 & 1 & 1 & 2 & 1 & 1 & 3 \\
\hline Tamias_panamintinus & 2 & 1 & 2 & 2 & 1 & 3 & 3 \\
\hline Tamias_quadrimaculatus & 2 & 6 & 2 & 2 & 1 & 1 & 3 \\
\hline Tamias_quadrivittatus & 2 & 6 & 2 & 2 & 1 & 1 & 3 \\
\hline Tamias_speciosus & 2 & 6 & 1 & 2 & 1 & 1 & 3 \\
\hline Tamias_striatus & 2 & 2 & 1 & 2 & 1 & 1 & 3 \\
\hline Tamias_townsendii & 2 & 2 & 2 & 2 & 1 & 1 & 3 \\
\hline Tamiasciurus_hudsonicus & 2 & 6 & 1 & 2 & 1 & 1 & 3 \\
\hline Tamiops_macclellandi & 2 & 6 & 1 & 2 & 1 & 3 & 3 \\
\hline Tatera_afra & 2 & 2 & 3 & 2 & 1 & 3 & 1 \\
\hline Tatera_brantsii & 1 & 2 & 3 & 2 & 1 & 3 & 1 \\
\hline Tatera_indica & 1 & 2 & 3 & 2 & 1 & 3 & 1 \\
\hline Tatera_leucogaster & 0 & 2 & 3 & 2 & 1 & 3 & 1 \\
\hline Thomomys_bottae & 4 & 2 & 5 & 1 & 1 & 2 \\
\hline Thomomy_talpoides & & 3 & 5 & 1 & 1 & 2 \\
\hline Thrichomys_apereoides & & & & & 2 & 1 & 1 \\
\hline
\end{tabular}




\begin{tabular}{|l|r|r|r|r|r|r|r|}
\hline Thrichomys_inermis & 1 & 1 & 3 & 5 & 2 & 1 & 1 \\
\hline Thryonomys_gregorianus & 1 & 1 & 3 & 3 & 2 & 3 & 1 \\
\hline Thryonomys_swinderianus & 2 & 5 & 3 & 3 & 2 & 2 & 1 \\
\hline Toromys_grandis & 0 & 6 & 1 & 5 & 2 & 1 & 1 \\
\hline Trinomys_albispinus & 0 & 1 & 1 & 5 & 2 & 1 & 1 \\
\hline Trinomys_dimidiatus & 1 & 1 & 1 & 5 & 2 & 1 & 1 \\
\hline Trinomys_eliasi & 1 & 1 & 1 & 5 & 2 & 2 & 1 \\
\hline Trinomys_iheringi & 2 & 1 & 1 & 5 & 2 & 1 & 1 \\
\hline Trinomys_minor & 2 & 1 & 3 & 5 & 2 & 1 & 1 \\
\hline Trinomys_paratus & 1 & 1 & 1 & 5 & 2 & 1 & 1 \\
\hline Trinomys_setosus & 0 & 1 & 1 & 5 & 2 & 2 & 1 \\
\hline Trinomys_yonenagae & 2 & 2 & 3 & 5 & 2 & 3 & 1 \\
\hline Tscherskia_triton & 2 & 2 & 3 & 2 & 1 & 1 & 1 \\
\hline Tympanoctomys_barrerae & 2 & 2 & 3 & 3 & 2 & 1 & 1 \\
\hline Uranomys_ruddi & 2 & 1 & 3 & 1 & 1 & 2 & 1 \\
\hline Wiedomys_pyrrhorhinos & 0 & 6 & 2 & 2 & 1 & 3 & 1 \\
\hline Xerus_erythropus & 2 & 2 & 3 & 2 & 1 & 3 & 3 \\
\hline Xerus_inauris & 2 & 2 & 3 & 2 & 1 & 3 & 3 \\
\hline Xerus_rutilus & 2 & 2 & 3 & 2 & 1 & 2 & 3 \\
\hline Zapus_hudsonius & 2 & 2 & 3 & 2 & 1 & 2 & 1 \\
\hline Zapus_princeps & 1 & 2 & 2 & 2 & 1 & 2 & 1 \\
\hline Zygogeomys_trichopus & 0 & 4 & 1 & 5 & 1 & 1 & 2 \\
\hline
\end{tabular}


Anexo IX Notação parentética (formato newick) da árvore filogenética com comprimento de ramo de 382 espécies de Rodentia utilizada neste trabalho.

((((('Allactaga_sibirica':4.0,(('Jaculus_jaculus':1.0,'Jaculus_orientalis':1.0):2.0,('Napaeozapus_in signis':2.0,('Zapus_hudsonius':1.0,'Zapus_princeps':1.0):1.0):1.0):1.0):16.0,(('Tachyoryctes_sple ndens':2.0,('Nannospalax_ehrenbergi':1.0,'Nannospalax_leucodon':1.0):1.0):17.0,((()(((('Mesem briomys_gouldii':4.0,('Melomys_cervinipes':3.0,('Melomys_rufescens':2.0,('Melomys_rubex':1.0, 'Melomys_levipes':1.0):1.0):1.0):1.0):1.0,('Notomys_alexis':2.0,('Pseudomys_australis':1.0,'Pseu domys_hermannsburgensis':1.0):1.0):3.0):1.0,('Pogonomys_macrourus':1.0,'Pogonomys_sylvestr is':1.0):5.0):1.0,'Chiropodomys_gliroides':7.0):4.0,(((((((('Praomys_morio':1.0,'Praomys_tullberg i':1.0):1.0,'Myomys_daltoni':2.0):1.0,('Mastomys_coucha':1.0,'Mastomys_natalensis':1.0):2.0):2. 0,('Mus_minutoides':4.0,('Mus_platythrix':3.0,('Mus_booduga':2.0,('Mus_triton':1.0,'Mus_muscu lus':1.0):1.0):1.0):1.0):1.0):1.0,('Apodemus_agrarius':2.0,('Apodemus_flavicollis':1.0,'Apodemus sylvaticus':1.0):1.0):4.0):1.0,'Malacomys_edwardsi':7.0):2.0,((((((('Arvicanthis_niloticus':2.0,(' Lemniscomys_rosalia':1.0,'Lemniscomys_striatus':1.0):1.0):1.0,(('Grammomys_cometes':1.0,'Gr ammomys_dolichurus':1.0):1.0,'Grammomys_rutilans':2.0):1.0):1.0,'Rhabdomys_pumilio':4.0):1. 0,(('Aethomys_chrysophilus':1.0,'Aethomys_hindei':1.0):1.0,'Aethomys_namaquensis':2.0):3.0): 1.0,'Hybomys_trivirgatus':6.0):1.0,'Oenomys_hypoxanthus':7.0):1.0,('Otomys_angoniensis':1.0,' Otomys_irroratus':1.0):7.0):1.0):1.0,'Hydromys_chrysogaster':10.0):1.0):2.0,('Micromys_minutu s':12.0,((((()(('Rattus_exulans':1.0,'Rattus_rattus':1.0):1.0,'Rattus_norvegicus':2.0):1.0,'Rattus_ni tidus':3.0):3.0,('Rattus_leucopus':5.0,('Rattus_fuscipes':4.0,('Rattus_lutreolus':3.0,('Rattus_tunney i':2.0,('Rattus_sordidus':1.0,'Rattus_colletti':1.0):1.0):1.0):1.0):1.0):1.0):1.0,'Sundamys_muelleri': 7.0):1.0,'Berylmys_bowersi':8.0):1.0,'Stenomys_niobe':9.0):1.0,('Leopoldamys_edwardsi':1.0,'Le opoldamys_sabanus':1.0):9.0):1.0,('Maxomys_rajah':2.0,('Maxomys_surifer':1.0,'Maxomys_whit eheadi':1.0):1.0):9.0):1.0):1.0):1.0,(((((('Meriones_hurrianae':1.0,'Meriones_libycus':1.0):1.0,'M eriones_crassus':2.0):1.0,'Meriones_unguiculatus':3.0):1.0,'Meriones_shawi':4.0):1.0,(('Gerbillus _gleadowi':2.0,('Gerbillus_dasyurus':1.0,'Gerbillus_campestris':1.0):1.0):1.0,'Gerbillus_pyramidu m':3.0):2.0):1.0,('Tatera_indica':4.0,('Gerbillurus_paeba':3.0,(('Tatera_brantsii':1.0,'Tatera_afra':1 $.0): 1.0$, 'Tatera_leucogaster':2.0):1.0):1.0):2.0):1.0,((('Lophuromys_flavopunctatus':1.0,'Lophuro mys_sikapusi':1.0):1.0,('Acomys_cahirinus':1.0,'Acomys_wilsoni':1.0):1.0):1.0,'Uranomys_ruddi ':3.0):4.0):7.0):3.0,((('Mesocricetus_auratus':3.0,('Cricetulus_barabensis':2.0,('Cricetus_cricetus': 1.0,'Tscherskia_triton':1.0):1.0):1.0):9.0,(('Sigmodon_hispidus':6.0,(((('Phyllotis_darwini':1.0,'Ca lomys_callosus':1.0):1.0,'Wiedomys_pyrrhorhinos':2.0):1.0,('Akodon_azarae':1.0,'Rhipidomys mastacalis':1.0):2.0):2.0,((('Holochilus_chacarius':1.0,'Holochilus_sciureus':1.0):1.0,'Nectomys squamipes':2.0):1.0,('Oligoryzomys_longicaudatus':1.0,'Oligoryzomys_nigripes':1.0):2.0):1.0,'Or yzomys_palustris':4.0):1.0):1.0):5.0,(('Nyctomys_sumichrasti':1.0,'Ototylomys_phyllotis':1.0):9. $0,((((()($ Neotoma_floridana':1.0,'Neotoma_albigula':1.0):1.0,'Neotoma_micropus':2.0):1.0,'Neot oma_goldmani':3.0):1.0,'Neotoma_mexicana':4.0):1.0,'Neotoma_stephensi':5.0):1.0,('Neotoma_f uscipes':1.0,'Neotoma_lepida':1.0):5.0):1.0,('Onychomys_leucogaster':1.0,'Onychomys_torridus': 1.0):6.0):2.0,((('Reithrodontomys_megalotis':1.0,'Isthmomys_pirrensis':1.0):1.0,('Ochrotomys_n uttalli':1.0,'Podomys_floridanus':1.0):1.0):6.0,('Megadontomys_thomasi':7.0,((('Peromyscus_boy lii':2.0,('Peromyscus_truei':1.0,'Peromyscus_aztecus':1.0):1.0):-2.0,('Peromyscus_megalops': $3.0,(($ 'Peromyscus_melanophrys':1.0,'Peromyscus_melanocarpus':1.0):1.0,('Peromyscus_guatemalensi s':1.0,'Peromyscus_mexicanus':1.0):1.0):1.0):1.0):2.0,(((('Peromyscus_leucopus':1.0,'Peromyscus gossypinus':1.0):2.0,('Peromyscus_melanotis':2.0,('Peromyscus_polionotus':1.0,'Peromyscus_m aniculatus':1.0):1.0):1.0):1.0,('Peromyscus_eremicus':1.0,'Peromyscus_californicus':1.0):3.0):1.0, 
'Peromyscus_crinitus':5.0):1.0):1.0):1.0):1.0):1.0):1.0):1.0):4.0,(('Dicrostonyx_groenlandicus':1.0 ,'Dicrostonyx_torquatus':1.0):14.0,(('Synaptomys_cooperi':3.0,('Myopus_schisticolor':2.0,('Lem mus_lemmus':1.0,'Lemmus_sibiricus':1.0):1.0):1.0):11.0,(('Ondatra_zibethicus':1.0,'Neofiber_all eni':1.0):12.0,(('Clethrionomys_rufocanus':3.0,('Clethrionomys_glareolus':2.0,('Clethrionomys_g apperi':1.0,'Clethrionomys_rutilus':1.0):1.0):1.0):9.0,('Arvicola_terrestris':11.0,((((('Microtus_xa nthognathus':5.0,('Microtus longicaudus':4.0,('Microtus oregoni':3.0,(('Microtus pennsylvanicu

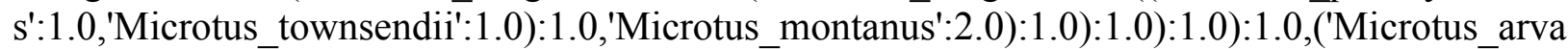
lis':1.0,'Microtus_guentheri':1.0):5.0):1.0,'Microtus_agrestis':7.0):1.0,'Microtus_californicus':8.0) :1.0,'Microtus_pinetorum':9.0):1.0,'Microtus_ochrogaster':10.0):1.0):1.0):1.0):1.0):1.0):1.0):1.0): 1.0,(('Dendromus_mystacalis':1.0,'Malacothrix_typica':1.0):3.0,('Beamys_hindei':3.0,('Mystromy s_albicaudatus':2.0,('Cricetomys_gambianus':1.0,'Saccostomus_campestris': 1.0):1.0):1.0):1.0):14 $.0): 1.0): 1.0): 1.0,{ }^{\prime}$ Pedetes_capensis':21.0):1.0,(('Castor_canadensis':1.0,'Castor_fiber':1.0):11.0,((' Thomomys bottae': 1.0,'Thomomys_talpoides':1.0):10.0, ((()(('Orthogeomys_heterodus':0.5,'Orth ogeomys_cherriei':1.0):0.5,'Orthogeomys_hispidus':1.0):1.0,'Pappogeomys_gymnurus':2.0):1.0,' Zygogeomys_trichopus':3.0):1.0,('Geomys_bursarius':1.0,'Geomys_pinetis':1.0):3.0):6.0,((((('Dip odomys_ordii':5.0,(((('Dipodomys_panamintinus':1.0,'Dipodomys_heermanni':1.0):1.0,'Dipodom ys_microps':2.0):1.0,'Dipodomys_agilis':3.0):1.0,'Dipodomys_merriami':4.0):1.0):1.0,'Dipodomy s_spectabilis':6.0):1.0,'Dipodomys_deserti':7.0):1.0,('Microdipodops_megacephalus':1.0,'Microdi podops_pallidus':1.0):7.0):1.0,((('Perognathus_flavus':1.0,'Perognathus_longimembris':1.0):1.0,' Perognathus_parvus':2.0):3.0,(('Chaetodipus_baileyi':1.0,'Chaetodipus_formosus': 1.0):3.0, ('Chae todipus_hispidus':3.0,('Chaetodipus_penicillatus':2.0,('Chaetodipus_fallax':1.0,'Chaetodipus_cali fornicus':1.0):1.0):1.0):1.0):1.0):1.0,('Liomys_salvini':3.0,('Heteromys_desmarestianus':2.0,('Lio mys_pictus':1.0,'Liomys_irroratus':1.0):1.0):1.0):3.0):3.0):1.0):1.0):1.0):10.0):1.0,(('Massoutiera _mzabi':1.0,'Pectinator_spekei':1.0):18.0,((('Hystrix_africaeaustralis':1.0,'Hystrix_cristata':1.0):1. $\overline{0}$, 'Atherurus_africanus':2.0):16.0,((('Thryonomys_swinderianus': 1.0, 'Thryonomys_gregorianus': 1 .0):5.0,('Heterocephalus_glaber':5.0,('Heliophobius_argenteocinereus':4.0,((('Cryptomys_hottent otus':1.0,'Fukomys_mechowi':1.0):1.0,'Fukomys_anselli':2.0):1.0,('Georychus_capensis':2.0,('Bat hyergus_suillus':1.0,'Bathyergus_janetta':1.0):1.0):1.0):1.0):1.0):1.0):11.0,((('Ágouti_paca':7.0,((' Myoprocta_acouchy':3.0,('Dasyprocta_leporina':2.0,('Dasyprocta_punctata':1.0,'Dasyprocta_pry

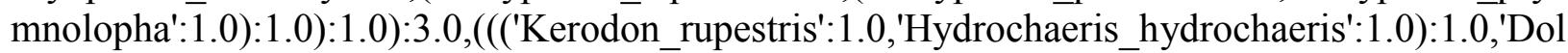
ichotis_patagonum':2.0):3.0,(('Microcavia_australis':3.0,('Cavia_porcellus':2.0,('Cavia_pamparu m':1.0,Cavia_aperea:1.0):1.0):1.0):1.0,('Galea_musteloides':1.0,'Galea_spixii':1.0):3.0):1.0):1.0): 1.0):1.0,(('Erethizon_dorsatum':1.0,'Sphiggurus_villosus':1.0):1.0,'Chaetomys_subspinosus':2.0): 6.0):8.0,(('Dinomys_branickii':3.0,('Lagostomus_maximus':2.0,('Chinchilla_lanigera':1.0,'Lagidi um_viscacia':1.0):1.0):1.0):12.0,((('Ctenomys_leucodon':12.0,(('Ctenomys_tuconax':10.0,('Cteno mys_boliviensis':9.0,(('Ctenomys_maulinus':2.0,('Ctenomys_opimus':1.0,'Ctenomys_fulvus':1.0) :1.0):6.0,(('Ctenomys_talarum':1.0,'Ctenomys_pundti':1.0):6.0,('Ctenomys_bonettoi':6.0,(('Cteno mys_rionegrensis':1.0,'Ctenomys_flamarioni':1.0):4.0,('Ctenomys_azarae':4.0,('Ctenomys_mend ocinus':3.0,('Ctenomys_porteousi':2.0,('Ctenomys_chasiquensis': 1.0,'Ctenomys_australis': 1.0$): 1$. 0):1.0):1.0):1.0):1.0):1.0):1.0):1.0):1.0):1.0,(('Ctenomys_magellanicus':3.0,('Ctenomys_emilianu $\mathrm{s}^{\prime}: 2.0,($ 'Ctenomys_sociabilis':1.0,'Ctenomys_haigi':1.0):1.0):1.0):4.0,('Ctenomys_tucumanus':6.0, ('Ctenomys_latro':5.0,(('Ctenomys_argentinus':1.0,'Ctenomys_occultus':1.0):3.0,(('Ctenomys_tor quatus':2.0,('Ctenomys_lami':1.0,'Ctenomys_minutus':1.0):1.0):1.0,('Ctenomys_dorbignyi':2.0,(' Ctenomys_roigi':1.0,'Ctenomys_perrensis':1.0):1.0):1.0):1.0):1.0):1.0):1.0):4.0):1.0):1.0,(('Octod on_degus':3.0,('Spalacopus_cyanus':2.0,('Aconaemys_sagei':1.0,'Aconaemys_porteri':1.0):1.0):1. $0): 1.0,\left(\left(' T y m p a n o c t o m y s \_b a r r e r a e ': 1.0\right.\right.$, 'Octomys_mimax':1.0):1.0,'Octodontomys_gliroides':2.0) 
:2.0):9.0):1.0,(((('Euryzygomatomys_spinosus':1.0,'Clyomys_bishopi':1.0):1.0,'Carterodon_sulci dens':2.0):4.0,(('Trinomys_albispinus':1.0,'Trinomys_minor':1.0):4.0,(('Trinomys_yonenagae':3.0 ,('Trinomys_setosus':2.0,('Trinomys_eliasi':1.0,'Trinomys_paratus':1.0):1.0):1.0):1.0,('Trinomys_ dimidiatus':1.0,'Trinomys_iheringi':1.0):3.0):1.0):1.0):4.0,(('Lonchothrix_emiliae':1.0,'Isothrix_ bistriata':1.0):3.0,(('Kannabateomys_amblyonyx':1.0,'Dactylomys_dactylinus':1.0):2.0,('Echimy s chrysurus':1.0,'Toromys grandis':1.0):1.0,('Makalata_armata':1.0,'Callistomys pictus':1.0):1.0) $: 1.0): 1.0): 5.0,($ Myocastor_coypus':8.0,('Thrichomys_apereoides':1.0,'Thrichomys_inermis':1.0): 6.0,('Hoplomys_gymnurus':6.0,('Proechimys_goeldii':5.0,('Proechimys_oris':4.0,('Proechimys_lo ngicaudatus':3.0,('Proechimys_guyannensis':2.0,('Proechimys_cuvieri':1.0,'Proechimys_semispin osus':1.0):1.0):1.0):1.0):1.0):1.0):1.0):1.0):1.0):1.0):1.0,('Capromys_pilorides':1.0,'Geocapromys ingrahami':1.0):10.0):3.0):1.0):1.0):1.0):1.0):1.0):4.0):1.0,(('Aplodontia_rufa':15.0, $\left(\left(\left(\left(()\left(\left(\left(\left(\left(\left(C^{\prime}\right.\right.\right.\right.\right.\right.\right.\right.\right.\right.$ Marmota_sibirica':1.0,'Marmota_marmota':1.0):1.0,'Marmota_monax':2.0):1.0,'Marmota_flavive ntris':3.0):1.0,('Spermophilus_beecheyi':1.0,'Spermophilus_lateralis':1.0):3.0):1.0,'Spermophilus_ tereticaudus':5.0):1.0,('Cynomys_ludovicianus':2.0,('Cynomys_gunnisoni':1.0,'Cynomys_leucuru s':1.0):1.0):4.0):1.0,'Spermophilus_franklinii':7.0):1.0,'Spermophilus_tridecemlineatus':8.0):1.0,( ((('Spermophilus_undulatus':1.0,'Spermophilus_columbianus':1.0):1.0,('Spermophilus_parryii':1. 0,'Spermophilus_richardsonii':1.0):1.0):1.0,'Spermophilus_beldingi':3.0):1.0,'Spermophilus_tow nsendii':4.0):5.0):1.0,(('Ammospermophilus_leucurus':1.0,'Ammospermophilus_nelsoni':1.0):1.0, 'Ammospermophilus_harrisii':2.0):8.0):1.0,((((('Tamias_dorsalis':1.0,'Tamias_palmeri':1.0):1.0,' Tamias_quadrivittatus':2.0):1.0,('Tamias_quadrimaculatus':2.0,('Tamias_minimus':1.0,'Tamias_p anamintinus':1.0):1.0):1.0):1.0,'Tamias_amoenus':4.0):1.0,('Tamias_townsendii':1.0,'Tamias_spe ciosus': 1.0):4.0):1.0,'Tamias_striatus':6.0):5.0):1.0,('Heliosciurus_ruwenzorii':2.0,('Heliosciurus gambianus':1.0,'Heliosciurus_rufobrachium':1.0):1.0):5.0,(('Protoxerus_stangeri':1.0,'Protoxerus aubinnii':1.0):5.0,(('Funisciurus_pyrropus':4.0,('Funisciurus_anerythrus':3.0,('Funisciurus_carrut hersi':2.0,('Funisciurus_lemniscatus':1.0,'Funisciurus_substriatus':1.0):1.0):1.0):1.0):1.0,('Paraxer us_cepapi':1.0,'Paraxerus_poensis':1.0):4.0):1.0):1.0):5.0):1.0,('Spermophilopsis_leptodactylus':3 $.0,(($ Xerus_erythropus':1.0,'Xerus_rutilus':1.0):1.0,'Xerus_inauris':2.0):1.0):10.0):1.0,((('Tamias ciurus_hudsonicus':5.0,((('Sciurus_carolinensis':1.0,'Sciurus_niger':1.0):1.0,'Sciurus_granatensis ':2.0):1.0,'Sciurus_vulgaris':3.0):1.0,'Sciurus_aureogaster':4.0):1.0):1.0,(('Pteromys_volans':4.0,(( ('Petaurista_petaurista':1.0,'Petaurista_elegans':1.0):1.0,'Pteromyscus_pulverulentus':2.0):1.0,'Aer omys_tephromelas':3.0):1.0):1.0,(('Glaucomys_volans':1.0,'Glaucomys_sabrinus':1.0):1.0,'Hylo petes_spadiceus':2.0):1.0,'Iomys_horsfieldii':3.0):2.0):1.0):1.0,(('Ratufa_bicolor':1.0,'Ratufa_affi nis':1.0):1.0,'Ratufa_indica':2.0):5.0):1.0,('Funambulus_pennantii':5.0,(('Tamiops_macclellandi': 1.0,'Dremomys_rufigenis': 1.0):3.0,('Rhinosciurus_laticaudatus':3.0,('Callosciurus_nigrovittatus': 1.0,'Callosciurus_prevostii':1.0):1.0,('Callosciurus_caniceps':1.0,'Callosciurus_notatus':1.0):1.0): 1.0):1.0):1.0):3.0):6.0):1.0):1.0,('Glis_glis':1.0,'Graphiurus_murinus':1.0):15.0):8.0):1.0; 